\title{
本邦鐵鑛及鐵鋼材需給額調
}

鐵鑛

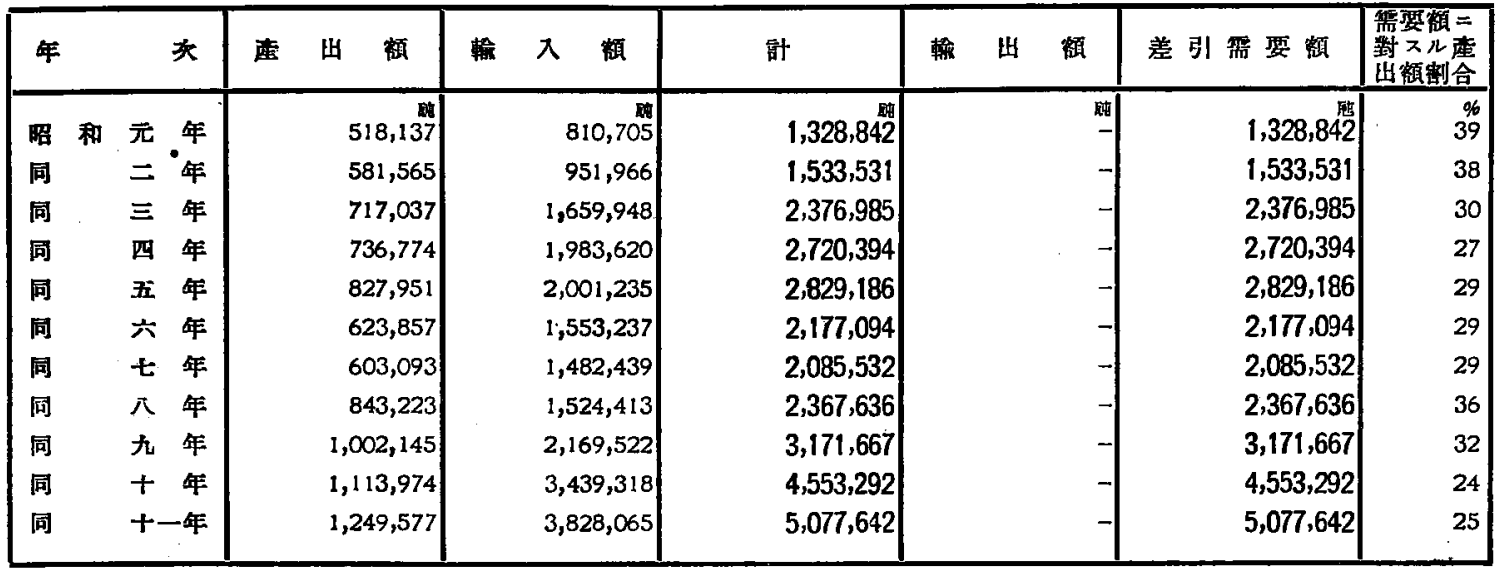

銑鐵

\begin{tabular}{|c|c|c|c|c|c|c|c|c|c|c|c|}
\hline 年 & 光 & 生 & 額 & 輸 & 入 & 計 & & 出 & 額 & 差引垌要額 & 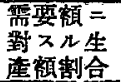 \\
\hline 昭 和 & 元 年 & & 924,660 & & 405,232 & $1,329,892$ & & & 1,879 & $1,328,013$ & 70 \\
\hline 同 : & 二 年 & & $1,025,193$ & & 480,069 & $1,505,262$ & & & 3,095 & $1,502,167$ & 68 \\
\hline 同 & 三 年 & & $1,238,695$ & & 575,952 & $1,814,647$ & & & 2,494 & $1,812,153$ & 68 \\
\hline 同 & 四 年 & & $1,240,755$ & & 661,123 & $1,901,878$ & & & 2,220 & $1,899,658$ & 65 \\
\hline 同 & 五 年 & & $1,312,418$ & & 410,629 & $1,723,047$ & & & 2,230 & $1,720,817$ & 76 \\
\hline 同 & 六 年 & & $1,064,599$ & & 402,778 & $1,467,377$ & & & 1,322 & $1,466,055$ & 73 \\
\hline 同 & 七 年 & & $1,172,701$ & & 451,115 & $1,623,816$ & & & 1,618 & $1,622,198$ & 72 \\
\hline 同 & 八 年 & & $1,597,845$ & & 647,748 & $2,245,593$ & & & 242 & $2,245,351$ & 71 \\
\hline 同 & 九 年 & & $1,938,965$ & & 623,178 & $2,562,143$ & & & 114 & $2,562,029$ & 76 \\
\hline 同 & 十 年 & & $2,118,228$ & & 970,584 & $3,088,812$ & & & 1 & $3,088,811$ & 69 \\
\hline 同 & 十一年 & & $2,224,322$ & & 983,842 & $3,208,164$ & & & 9 & $3,208,155$ & 69 \\
\hline
\end{tabular}

鋼材

\begin{tabular}{|c|c|c|c|c|c|c|c|c|c|c|c|}
\hline 年 & 天 & 生 & 搉 & 軪 & 入 賏 & & 竐 & 輸 & 出 & 差引需要 頼 & 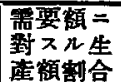 \\
\hline 昭 和： & 元 年 & & $1,256,305$ & & 929,613 & & $2,185,915$ & & 26,758 & $2,159,157$ & $\begin{array}{r}96 \\
58\end{array}$ \\
\hline 同 & 二 年 & & $1,415,121$ & & 817,654 & & $2,232,775$ & & 17,241 & $2,215,534$ & 64 \\
\hline 同 & 三 年 & & $1,720,489$ & & 831,961 & & $2,552,450$ & & 25,973 & $2,526,477$ & 68 \\
\hline 同 & 四 年 & & $2,033,880$ & & 798,331 & & $2,832,211$ & & 28,088 & $2,804,123$ & 73 \\
\hline 同 & 五 年 & & $1,921,066$ & & 412,305 & & $2,363,371$ & & 70,412 & $2,292,959$ & 84 \\
\hline 同 & 六 年 & & $1,662,858$ & & 267,044 & & $1,929,902$ & & 71,113 & $1,858,789$ & 89 \\
\hline 同 & 七 年 & & $2,112,598$ & & 234,302 & 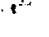 & $2,346,900$ & & 123,699 & $2,223,201$ & 95 \\
\hline 同 & 八年 & & $2,791,948$ & & 403,224 & & $3,195,172$ & & 267,535 & $2,927,637$ & 95 \\
\hline 同 & 九 年 & & $3,344,276$ & & 373,906 & & $3,718,182$ & & 401,317 & $3,316,865$ & 101 \\
\hline 同 & 十年 & & $4,027,907$ & & 319,414 & & $4,347,321$ & & 499,068 & $3,848,253$ & 104 \\
\hline 同 & 十一年 & & $4,595,198$ & & 301,300 & & $4,896,498$ & & 578,851 & $4,317,647$ & 106 \\
\hline
\end{tabular}




\section{內地鐵 鑛需要額調}

\begin{tabular}{|c|c|c|c|c|c|c|c|c|c|c|c|c|}
\hline \multirow{2}{*}{ 年 } & \multirow{2}{*}{\multicolumn{2}{|c|}{ 次 }} & \multirow{2}{*}{ 座出頼 } & 輸 & 移 & 䫈 & \multirow{2}{*}{ 合 暗 } & \multicolumn{2}{|c|}{ 桠 移 } & 出 & \multirow{2}{*}{$\begin{array}{l}\text { 差 引 } \\
\text { 篅要顧 }\end{array}$} & \multirow{2}{*}{ 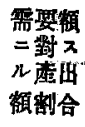 } \\
\hline & & & & 柾入観 & 移入䫁 & 部 & & 輸性類 & 移比頼： & 的 & & \\
\hline 大正 & 元 & 年 & 152,983 & 198,211 & $\begin{array}{r}\text { 123,405 } \\
120\end{array}$ & 321,616 & 474,599 & & 略 & 施 & 474,599 & $\begin{array}{l}\% \\
32\end{array}$ \\
\hline 同 & $=$ & 年 & 153,101 & 279,896 & 142,420 & 422,316 & 575,417 & & & & 575,417 & 227 \\
\hline 同 & $\equiv$ & 年 & 121,636 & 298,868 & 162,044 & 460,912 & 582,548 & & 不 & & 582,548 & 21 \\
\hline 同 & 四 & 年 & 118,955 & 308,788 & 201,978 & 510,766 & 629,721 & & & & 629,721 & 19 \\
\hline 同 & 五 & 年 & 139,953 & 279,791 & 190,225 & 470,016 & 609,969 & & 歚 & & 609,969 & 23 \\
\hline 同 & 六 & 年 & 267,594 & 296,881 & 120,907 & 417,788 & 685,382 & & & & 685,382 & 39 \\
\hline 同 & 七 & 年 & 378,114 & 360,930 & 236,611 & 597,541 & 975,655 & & & & 975,655 & 39 \\
\hline 同 & $\pi$ & 年 & 362,949 & 621,086 & 333,521 & 954,607 & $1,317,556$ & & 2,656 & 2,656 & $1,314,900$ & 28 \\
\hline 同 & 九 & 年 & 314,858 & 662,368 & 332,533 & 994,901 & $1,309,759$ & & 8,075 & 8,075 & $1,301,684$ & 24 \\
\hline 同 & + & 年 & 86,977 & 578,056 & 190,541 & 768,597 & 855,574 & & & & 855,574 & 10 \\
\hline 同 & +- & & 39,744 & 818,510 & 89,827 & 908,337 & 948,081 & & 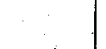 & & 948,081 & 4 \\
\hline 同 & $+=$ & & 55,174 & 893,260 & 95,390 & 988,650 & $1,043,824$ & & 文 & & $1,043,824$ & 5 \\
\hline 同 & $+\equiv$ & 年 & 57,922 & $1,065,132$ & 136,727 & $1,201,859$ & $1,259,781$ & & & & $1,259,781$ & 5 \\
\hline 同 & + 四 & & 75,765 & $1,103,7,09$ & 107,868 & $1,211,577$ & $1,287,342$ & & & & $1,287,342$ & 6 \\
\hline 昭 和 & $\bar{\pi}$ & & 130,420 & 792,830 & 98,992 & 891,822 & $1,022,242$ & & 辟 & & $1,022,242$ & 13 \\
\hline 同 & & 年 & 159,005 & 937,488 & 168,764 & $1,106,252$ & $1,265,257$ & & & & $1,265,257$ & 13 \\
\hline 同 & $\equiv$ & 年 & 157,706 & $1,616,974$ & 225,389 & $1,842,363$ & $2,000,069$ & & & & $2,000,069$ & 8 \\
\hline 同 & 四 & 年 & 177,556 & $1,944,786$ & 314,134 & $2,258,920$ & $2,436,476$ & - & 4,299 & 4,299 & $2,432,177$ & 7 \\
\hline 同 & 五 & 年 & 245,991 & $1,973,659$ & 287,727 & $2,261,386$ & $2,507,377$ & - & 2,466 & 2,466 & $2,504,911$ & 10 \\
\hline 同 & 六 & 年 & 208,181 & $1,549,919$ & 176,585 & $1,726,504$ & $1,934,685$ & -1 & 5,176 & $-5,176$ & $1,929,509$ & 11 \\
\hline 同 & 七 & & 226,722 & $1,482,409$ & 151,604 & $1,634,013$ & $1,860,735$ & - & 4,252 & $: 4,252$ & $1,856,483$ & 12 \\
\hline 同 & 八. & & 320,670 & $1,523,627$ & 255,320 & $1,778,947$ & $2,099,617$ & - & 5,620 & 5,620 & $2,093,997$ & 15 \\
\hline 同 & 九 & & 431,681 & $2 ; 131,916$ & 180,511 & $2,312,427$ & $2,744,108$ & - & 5,539 & 5,539 & $2,738,569$ & 16 \\
\hline 同 & + & & 515,865 & $3,404,099$ & 242,197 . & $3,646,296$ & $4,162,161$ & - & 5,714 & 5,714 & $4,156,447$ & 12 \\
\hline 同. & +- & & 620,449 & $3,780,109$ & 242,737 & $\begin{array}{c}4,022,846 \\
\cdots\end{array}$ & $4,643,295$ & - & & - & $4,643,295$ & 13 \\
\hline
\end{tabular}




\section{內地銑鐵需要額調}

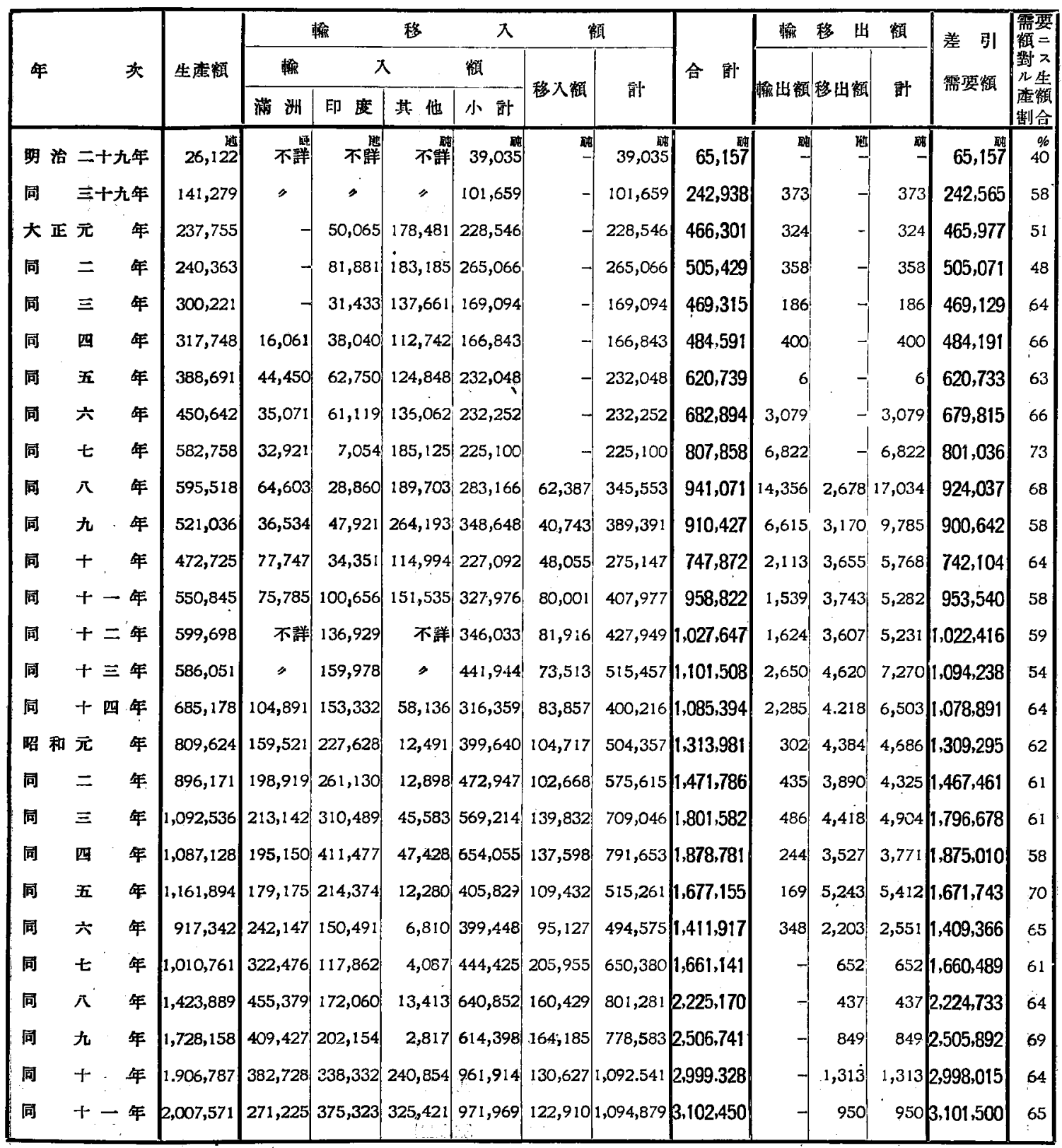

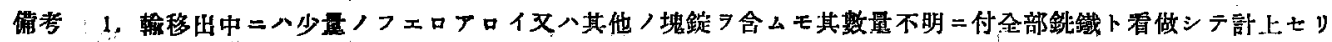

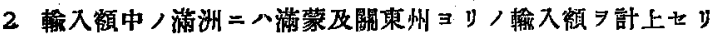


內地フェロアロイ需要額調

\begin{tabular}{|c|c|c|c|c|c|c|c|c|c|c|c|c|}
\hline \multirow{2}{*}{ 年 } & \multirow{2}{*}{\multicolumn{2}{|c|}{ 次 }} & \multirow{2}{*}{ 生产顧 } & 翰 & 移 & 額 & \multirow{2}{*}{ 合敫 } & \multirow{2}{*}{$\frac{\text { 輸 }}{\text { 輸出顧 }}$} & 移比 & 顧 & 差 引 & \multirow{2}{*}{ 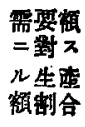 } \\
\hline & & & & 檢 大顧 & 夥入额 & 的 & & & 移出顀 & 暗 & 監要 顧 & \\
\hline 大正 & & 年 & 1,413 & 3,466 & $i$ & 3,466 & 4,879 & - & 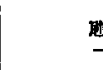 & 洫 & 4,879 & 29 \\
\hline 同 & $=$ & & 2,313 & 8,243 & & 8,243 & 10,556 & - & - & - & 10,556 & 22 \\
\hline 同 & $\equiv$ & & 1,505 & 3,043 & & 3,043 & 4,548 & : & - & - & 4,548 & 33 \\
\hline 同 & 四 & & 2,879 & 5,842 & & 5,842 & 8,721 & - & .. & - & 8,721 & 33 \\
\hline 同 & 五 & & 3,201 & 5,607 & & 5,607 & 8,808 & - & & - & 8,808 & 36 \\
\hline 同 & 六 & 年 & 12,150 & 2,830 & & 2,830 & 14,980 & - & & - & 14,980 & 81 \\
\hline 同 & $t$ & 年 & 23,670 & 1,221 & & 1,221 & 24,891 & - & & - & 24,891 & 95 \\
\hline 同 & 八 & & 17,091 & 3,154 & & 3,154 & 20,245 & - & . & - & 20,245 & 84 \\
\hline 同 & 九 & & 8,839 & 1,075 & & 1,075 & 9,914 & - & & - & 9,914 & 89 \\
\hline 同 & + & & 7,575 & 1,137 & . & 1,137 & 8,712 & - & - & - & 8,712 & 87 \\
\hline 同 & +- & & 8,465 & 1,629 & & 1,629 & 10,094 & - & - & - & 10,094 & 84 \\
\hline 同 & $+=$ & & 11,053 & 1,493 & & 1,493 & 12,546 & - & - & - & 12,546 & 88 \\
\hline 间 & $+\equiv$ & & 12,978 & 4,665 & & 4,665 & 17,643 & - & - & - & 17,643 & 74 \\
\hline 同 & + 四 & & 11,542 & 2,352 & & 2,352 & 13,894 & & & - & 13,894 & 83 \\
\hline 昭 和 & 元 & 年 & 12,208 & 4,055 & 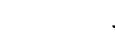 & 4,055 & 16,263 & - & & - & 16,263 & 75 \\
\hline 同 & $=$ & 年 & 16,012 & 5,055 & & 5,055 & 21,067 & - & - & - & 21,067 & 76 \\
\hline 同 & $\equiv$ & & 17,091 & 3,688 & & 3,688 & 20,779 & - & - & - & 20,779 & 82 \\
\hline 同 & 四 & & 25,309 & 3,208 & . & 3,208 & 28,517 & - & - & - & 28,517 & 89 \\
\hline 同 & 五 & & 25,597 & 2,750 & & 2,750 & 28,347 & - & - & - & 28,347 & 90 \\
\hline 同 & 共 & & 16,846 & 1,287 & $\ldots$ & 1,287 & 18,133 & - & 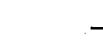 & - & 18,133 & 93 \\
\hline 同 & t & 年 & 25,916 & 582 & . & 582 & 26,498 & - & . & - & 26,498 & 98 \\
\hline 同 & 公. & & 32,986 & 544 & . & 544 & 33,530 & & & - & 33,530 & 98 \\
\hline 同 & 九 & & 44,217 & 135 & . & 135 & 44,352 & & & - & 44,352 & 100 \\
\hline 同 & + & & 57,820 & 243 & . & 243 & 58,063 & - & - & - & 58,063 & 100 \\
\hline 同 & +- & & 64,868 & 49 & & 49 & 64,917 & - & 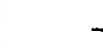 & - & 64,917 & 100 \\
\hline
\end{tabular}

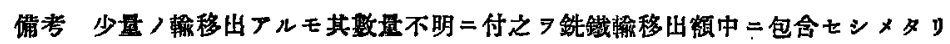




\section{内地鋼 材需要額調}

\begin{tabular}{|c|c|c|c|c|c|c|c|c|c|c|c|}
\hline \multirow{2}{*}{ 年 } & \multirow{2}{*}{ 次 } & \multirow{2}{*}{ 生荹顧 } & 輸 & 移 & 顧 & \multirow{2}{*}{ 合 諯 } & \multicolumn{2}{|c|}{ 輸 移 } & 出 & \multirow{2}{*}{ 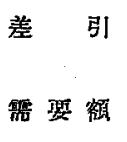 } & \multirow{2}{*}{ 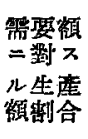 } \\
\hline & & & 输 入顧 & 移入衤 & 計 & & 輸出頪 & 移出額 & 时 & & \\
\hline 明治 & 二十九年 & 1,192 & 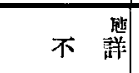 & 不 溾 & 220,757 & 221,949 & & & 酗 & 221,949 & $0 \%$ \\
\hline & 三十九年 & 69,375 & ; & " & 348,136 & 417,511 & 不 誹 & 不 評 & 4,942 & 412,569 & 16 \\
\hline 大正 & 元 & 219,714 & 621,934 & 68 & 622,002 & 841,716 & 9,251 & 26,856 & 36,107 & 805,609 & 27 \\
\hline 同 & $=$ & 254,952 & 527,607 & 19 & 527,626 & 782,578 & 11,636 & 19,785 & 31,421 & 751,157 & 34 \\
\hline 同 & 三 年 & 282,516 & 395,252 & 300 & 395,552 & 678,068 & 11,365 & $.17,716$ & 29,081 & 648,987 & 44 \\
\hline 同： & 四 & 342,870 & 235,750 & 713 & 236,463 & 579,333 & 11,814 & 17,055 & 28,869 & 550,464 & 62 \\
\hline 同 & 五 & 381,221 & 442,188 & 260 & 442,448 & 823,669 & $.14,089$ & 12,334 & 26,423 & 797,246 & 48 \\
\hline 同 & 亲 年 & 5333,941 & 674,737 & 467 & 675,204 & $1,209,145$ & 37,928 & 15,875 & 53,803 & $1,155,342$ & 46 \\
\hline 同 & $t$ & 537,228 & 651,028 & 439 & 651,467 & $1,188,695$ & 52,341 & 13,988 & 66,329 & $1,122,366$ & 48 \\
\hline 同 & 八 & 548,527 & 721,831 & 3,100 & 724,991 & $1,273,518$ & 63,203 & 45,242 & 108,445 & $\uparrow, 165,073$ & 47 \\
\hline 同 & 九 & 533,387 & $1,024,743$ & 14,675 & $1,039,418$ & $1,572,805$ & 46,559 & 50,823 & 97,382 & $1,475,423$ & 36 \\
\hline 同 & + & 564,924 & 625,629 & 21,172 & 646,801 & $1,211,725$ & 26,075 & 58,656 & 84,731 & $1,126,994$ & 50 \\
\hline 同 & 十一年 & 661,781 & $1,088,447$ & 12,391 & $1,100,838$ & $1,762,619$ & 18,227 & 65,066 & 83,293 & $1,679,326$ & 39 \\
\hline 同 & 十二 年 & 754,674 & 796,847 & 2,330 & 799,177 & $1,553,851$ & 17,782 & 800,071 & 97,853 & $1,455,998$ & 52 \\
\hline 同 & $+三$ 年 & 841,347 & $1,151,676$ & 2,726 & $1,154,402$ & $1,995,749$ & 27,808 & 63,287 & 91,095 & $1,904,654$ & 44 \\
\hline 同 & 十四年 & $1,042,978$ & 531,034 & 1,857 & 532,891 & $1,575,869$ & 37,323 & 70,194 & 107,517 & $1,468,352$ & 71 \\
\hline 昭 和 & $\pi$ & $1,256,302$ & 923,028 & 1,703 & 924,731 & $2,181,033$ & 26,614 & 93,845 & 120,459 & $2,060,574$ & 61 \\
\hline 同 & $=$ & $1,415,121$ & 810,960 & 3,304 & 814,264 & $2,229,385$ & 16,292 & 139,451 & 155,743 & $2,073,642$ & 68 \\
\hline 同 & $\equiv$ & $1,720,489$ & 820,554 & 4,183 & 824,737 & $2,545,226$ & 23,134 & 158,810 & 181,944 & $2,363,282$ & 73 \\
\hline 同 & 四 & $2,033,880$ & 784,965 & 5,093 & 790,058 & $2,823,938$ & 25,654 & $1 \% 0,077$ & 195,731 & $2,628,207$ & 77 \\
\hline 同 & 五 & $1,921,066$ & 434,843 & 2,260 & 437,103 & $2,358,169$ & 67,022 & $.166,558$ & 233,580 & $2,124,589$ & 90 \\
\hline & 六 & $1,652,858$ & 263,161 & $2 ; 387$ & 265,548 & $1,928,406$ & 56,579 & 146,968 & 203,547 & $1,724,859$ & 96 \\
\hline 同 & $t$ & $2,112,598$ & 229,634 & 5,531 & 235,165 & $2,347,763$ & 115,729 & 184,138 & 299,867 & $2,047,896$ & 103 \\
\hline 同 & $\pi$ & $2,791,948$ & 399,978 & 9,884 & 409,862 & $3,201,810$ & 229,300 & 205,997 & 435,297 & $2,766,513$ & 101 \\
\hline 同 & 九 年 & $3,322,657$ & 370,584 & 56,074 & 426,658 & $3,749,315$ & 344,879 & 249,222 & 594,101 & $3,155,214$ & 105 \\
\hline 同 & 十 年 & $3,976,075$ & 315,893 & 41,346 & 357,239 & $4,333,314$ & 444,090 & 367,024 & 811,114 & $3,522,200$ & 113 \\
\hline 同 & 十一年 & $4,538,586$ & 296,074 & 48,924 & 344,998 & $4,883,584$ & 447,286 & 440,623 & 887,909 & $3,995,675$ & 114 \\
\hline
\end{tabular}

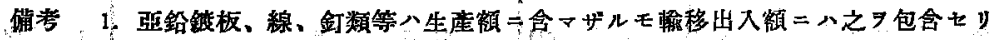

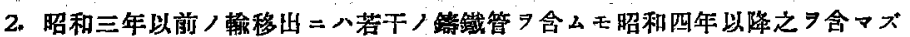


內地鋼材品種别需要額調

\begin{tabular}{|c|c|c|c|c|c|c|c|c|c|c|c|}
\hline \multirow{2}{*}{ 年 } & . & \multirow{2}{*}{ 次 } & \multirow{2}{*}{ 生站矤 } & 祎 & 大 & 额 & \multirow{2}{*}{ 合 } & & 移 & & \multirow{2}{*}{ 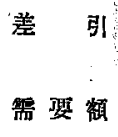 } \\
\hline & & & & 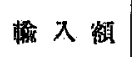 & 移入颗 & 部 & & 叠 出颂 & 移出額 & 尌 & \\
\hline 大 正 & 元 & 年 & 68,932 & 220,175 & $\begin{array}{r}32 \\
32\end{array}$ & 220,207 & 289,139 & $\begin{array}{r}\text { 珀 } \\
623\end{array}$ & 3,905 & 4,628 & 284,611 \\
\hline 同 & $=$ & 年 & 76,259 & 185,207 & 7 & 185,214 & 261,473 & 821 & 3,150 & 3,971 & 257,502 \\
\hline 同 & $\equiv$ & 年 & 78,070 & 151,749 & 140 & 151,889 & 229,959 & 433 & 3,542 & 3,975 & 225,984 \\
\hline 同 & 四 & 年 & 92,887 & 58,622 & 395 & 59,017 & 151,904 & 764 & 2,498 & 3,262 & 148,642 \\
\hline 同 & 五 & 年 & 134,161 & 143,658 & 95 & 143,753 & 277,914 & 2,044 & 1,983 & 4,027 & 273,887 \\
\hline 同 & 六 & 年 & 218,256 & 197,639 & 29 & $19^{\prime}, 668$ & 415,924 & 9,508 & 1,870 & 11,378 & 404,546 \\
\hline 同 & $-t$ & 年 & 221,343 & 265,791 & 110 & 265,901 & 487,244 & 22,316 & 878 & 23,194 & 464,050 \\
\hline 同 & 八 & 年 & 187,962 & 190,926 & 611 & 191,537 & 379,499 & 17,565 & 10,809 & 28,374 & 351,125 \\
\hline 同 & 九 & 年 & 213,125 & 297,349 & 2,926 & 300,275 & 513,400 & 13,937 & 9,692 & 23,629 & 489,771 \\
\hline 同 & + & 年 & 239,285 & 149,120 & 4,211 & 153,331 & 392,616 & 8,898 & 16,505 & 25,403 & 367,213 \\
\hline 同 & +- & 年 & 303,276 & 246,926 & 2,370 & 249,296 & 552,572 & 4,908 & 15,630 & 20,538 & 532,034 \\
\hline 同 & $t=$ & 年 & 330,758 & 199,321 & 331 & 199,652 & 530,410 & 5,916 & 19,817 & 25,733 & 504,677 \\
\hline 同 & $r \equiv$ & 年 & 414,425 & 304,116 & 329 & 304,445 & 718,870 & 10,269 & 17,965 & 28,234 & 690,636 \\
\hline 同 & 十四 & 年 & 482,144 & 138,288 & 122 & 138,410 & 620,554 & 10,078 & 21,447 & 31,525 & 589,029 \\
\hline 昭 和 & 元 & 年 & $597, \mathrm{C} 61$ & 278,296 & 60 & 278,356 & 875,417 & 5,760 & 31,994 & 37,754 & 837,663 \\
\hline 同 & $=$ & 年 & 668,838 & 200,157 & 133 & 205,290 & 875,128 & 5,312 & 43,906 & 49,218 & 825,910 \\
\hline 同 & $\equiv$ & 年 & 805,334 & 141,914 & 456 & 142,370 & 947,704 & 7,519 & 48,114 & 55,633 & 892,071 \\
\hline 同 & 四 & 年 & 939,394 & 190,739 & 106 & 190,845 & $1,130,239$ & 7,760 & 55,876 & 63,636 & $1,066,603$ \\
\hline 同 & 五 & 年 & 734,309 & 106,399 & 27 & 106,426 & 840,735 & 10,497 & 48,903 & 59,400 & 781,335 \\
\hline 同 & 六： & 年 & 669,841 & 38,280 & 62 & 38,342 & 708,183 & 23,290 & 42,703 & 65,993 & 642,190 \\
\hline 同 & $t$ & 年 & 820,848 & 38,726 & 98 & 38,824 & 859,672 & 20,107 & 55,143 & 75,250 & 784,422 \\
\hline 同 & $\pi$ & 年 & $1,105,268$ & 80,450 & 80 & 80,530 & $1,185,798$ & 45,134 & 63,417 & 108,551 & $1,077,247$ \\
\hline 同 & 九 & 年 & $1,208,772$ & 63,899 & 3,953 & 67,852 & $1,276,624$ & 108,395 & 81,263 & 189,658 & $1,086,966$ \\
\hline 同 & + & 年 & $1,483,580$ & 57,544 & 7,411 & 64,955 & $1,548,535$ & 110,750 & 122,464 & 233,214 & $1,315,321$ \\
\hline 同 & +- & 年 & $1,582,133$ & 37,002 & 7,347 & 44,349 & $1,626,482$ & 124,259 & 133,284 & 257,543 & $1,368,939$ \\
\hline
\end{tabular}

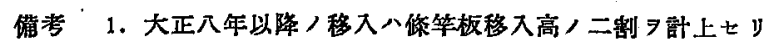

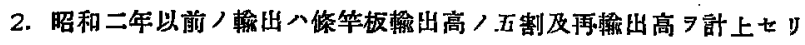




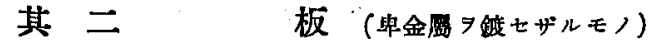

\begin{tabular}{|c|c|c|c|c|c|c|c|c|c|c|}
\hline \multirow{2}{*}{ 年 } & \multirow{2}{*}{ 欢 } & \multirow{2}{*}{ 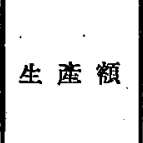 } & 軹 & 和 & 纇 & \multirow{2}{*}{ 合 部 } & 榆 & 移 & 頖 & \multirow{2}{*}{$\begin{array}{l}\text { 差 引 } \\
\text { 需 要 }\end{array}$} \\
\hline & & & 输入襀 & 移入襩 & 草 & & 輸些頪 & 移出頪 & 悺 & \\
\hline 太正元 年 & & 45,923 & 112,467 & 野 & $\begin{array}{l}\text { b日 } \\
112,467\end{array}$ & 158,390 & 485 & 3,497 & 3,982 & 154,408 \\
\hline 同 = 年 & & 58,010 & 95,049 & - & 95,049 & 153,059 & 190 & 2,098 & 2,288 & 150,771 \\
\hline 同 $\equiv$ & & 46,487 & 89,038 & 127 & 89,165 & 135,652 & 304 & 1,847 & 2,151 & 133,501 \\
\hline 同 四 年 & & 86,616 & 78,190 & 25 & 78,215 & 164,831 & 927 & 1,770 & 2,697 & 162,134 \\
\hline 同五牛 & & 71,926 & 161,159 & 19 & 161,178 & $.233,104$ & 3,316 & 1,546 & 4,862 & 228,242 \\
\hline 同 六 年 & & 77,323 & 299,191 & 33 & 299,224 & 376,547 & 8,621 & 1,922 & 10,543 & 366,004 \\
\hline 同 : 七 年 & & 91,386 & 160,702 & 49 & 160,751 & 252,137 & 14,881 & 767 & 15,648 & 236,489 \\
\hline 同: 公 年 & & 143,932 & 241,204 & 2,442 & 243,646 & 387,578 & 14,462 & 2,853 & 17,315 & 370,263 \\
\hline 同 九 年 & & 124,184 & 380,459 & 11,702 & 392,161 & 516,345 & (24;568 & 4,385 & 18,948 & 497,397 \\
\hline 同 + 年 & & 135,488 & 224,951 & 16,842 & 241,793 & 377,281 & $8 ; 808$ & 5,892 & 14,700 & 362,581 \\
\hline 同 $\therefore$ 十一年 & & 145,105 & 392,307 & 9,481 & 401,788 & 546,893 & 4,832 & 5,028 & 9,860 & 537,033 \\
\hline 同 + 二 年 & & 174,228 & 242,716 & 1,325 & 244,041 & 418,269 & 5,933 & 5,328 & 11,261 & 407,008 \\
\hline 问 $i+\equiv$ 年 & & 188,821 & 392,969 & 1,316 & 394,285 & 583,106 & 9,841 & 6,307 & 16,148 & 566,958 \\
\hline 同 $\therefore$ 十四年 & & 235,557 & 148,977 & 490 & 149,467 & 385,024 & 10,072 & 7,492 & 17,564 & 367,460 \\
\hline 昭和元 年 & & 280,357 & 260,886 & 239 & 261,125 & 541,482 & 5,166 & 11,444 & 16,610 & 524,872 \\
\hline 同 $=$ 年 & & 334,754 & 239,677 & 533 & 240,210 & 574,964 & 5,267 & 13,520 & 18,787 & 556,177 \\
\hline$\equiv$ & 4 & 418,339 & 270,824 & 1,824 & 272,648 & 690,987 & 7,322 & 18,640 & 25,962 & 665,025 \\
\hline 同 四 & 年 & 526,079 & 186,563 & 826 & 168,989 & 695,068 & 7,787 & 21,598 & 29,385 & 665,683 \\
\hline 同：五年 & 年 & 548,172 & 82,275 & 107 & 82,382 & 630,554 & 9,070 & 23,560 & 32,630 & 597,924 \\
\hline 网 六“年 & & 532,558 & 30,548 & 249 & 30,797 & 563,355 & 16,528 & 19,131 & 3,659 & 527,696 \\
\hline 同 七 作 & & 573,527 & 22,403 & 391 & 22,794 & 596,321 & 12,888 & 18,724 & 31,612 & 564,709 \\
\hline 阔 氿。 & & 747,138 & 88,613 & 320 & 88,933 & 836,071 & 18,167 & 17,761 & 35,928 & 800,143 \\
\hline 同 九 年 & & 927,610 & 68,834 & 15,814 & 84,648 & $1,012,258$ & 32,373 & 21,324 & 53,697 & 958,561 \\
\hline 同 $i+$ 年 & & $1,102,249$ & 49,666 & 29,646 & 79,312 & $1,181,561$ & 36,721 & 36,166 & 72,887 & $1,108,674$ \\
\hline 同 & & $1,397,881$ & - 30,918 & 30,803. & 61,721 & $1,459,602$ & 88,083 & 43,364 & 131,447 & $-1,328,155$ \\
\hline
\end{tabular}

简考 1. 大正八年以降ノ移入八條笔板移入高ノ八制 7 計上セり

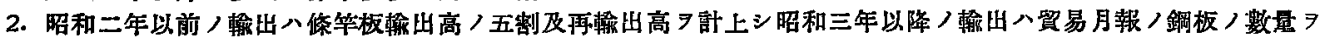
全部早金禺 7 镀せザルモノト看做シテ計上セり

3. 大正元年移出八板鐵線其他ノ三分ノー7即上セy 


\section{內地鋼材品種別需要額調}

其 $三 \quad フ^{*}$ ソ

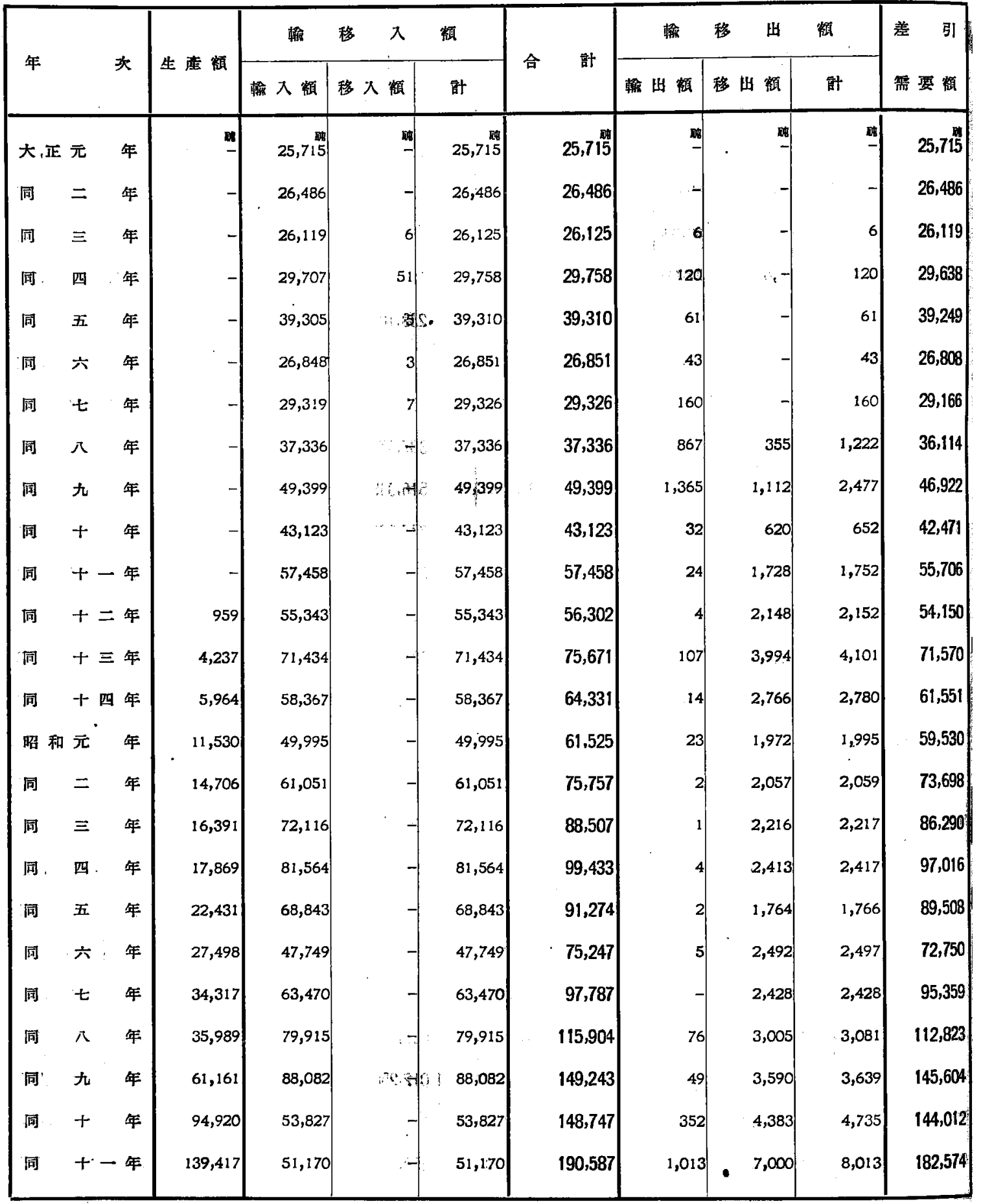


其 四線

材

\begin{tabular}{|c|c|c|c|c|c|c|c|c|c|c|c|}
\hline \multirow{2}{*}{\multicolumn{2}{|c|}{ 年 }} & \multirow{2}{*}{ 次 } & \multirow{2}{*}{ 生虑顧 } & & 移 ス゚ & 䒜 & \multirow{2}{*}{ 合 } & \multicolumn{3}{|c|}{ 輸 移 } & \multirow{2}{*}{ 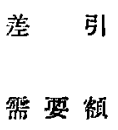 } \\
\hline & & & & 灀 入 頪 & 移入頪 & 的 & & 䡶 出㮌 & 䔟出額 & 鼓 & \\
\hline 大 & & & 15,649 & 2,531 & 明 & 2,531 & 18,180 & 영 & 暗 & 时 & 18.180 \\
\hline & & 年 & 25,895 & 4,595 & & 4,595 & 30,490 & - & - & - & 30,490 \\
\hline 同 & $\equiv$ & 年 & 29,470 & 3,457 & & 3,457 & 32,927 & - & $=$ & - & 32,927 \\
\hline & 四 & 年 & 35,198 & 10,005 & - & 10,005 & 45,203 & - & - & - & 45,203 \\
\hline 同 & 五 & 年 & 28,272 & 18,900 & & 18,900 & 47,172 & - & - & - & 47,172 \\
\hline 同 & 六 & 年 & 32,700 & 25,374 & - & 25,374 & 58,074 & - & - & - & 58,074 \\
\hline 同 & $t$ & 年 & 32,253 & 33,987 & & 33,987 & 66,240 & - & - & - & 66,240 \\
\hline 同 & 八 & 年 & 18,567 & 37,696 & & 37,696 & 56,263 & - & - & - & 56,263 \\
\hline 同 & 九 & 年 & 27,023 & 45,033 & - & 45,033 & 72,056 & - & - & - & 72,056 \\
\hline 同 & + & 年 & 29,538 & 21,533 & - & 21,533 & 51,071 & - & - & - & 51,071 \\
\hline 同 & + & 一年 & 27,573 & 54,078 & - & 54,078 & 81,651 & -1 & $\Rightarrow$ & - & 81,651 \\
\hline 同 & it & 年 & 39,598 & 54,327 & - & 54,327 & 93,925 & 100 & $\therefore$ & $\$ 100$ & 93,825 \\
\hline 同 & + & 年 & 31,665 & 88,242 & - & 88,242 & 119,907 & - & 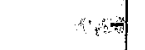 & at:- & 119,907 \\
\hline 同 & + & 年 & 48,603 & 51,319 & - & 51,319 & 99,922 & $-f$ & $\div$ & $\therefore$ & 99,922 \\
\hline 昭 & 元 & 年 & 50,384 & 117,971 & - & 117,971 & 168,355 & .90 & - & 90 & 168,265 \\
\hline 同 & $=$ & 年 & 54,426 & 109,090 & - & 109,090 & 163,516 & $\therefore$ & - & - & 163,516 \\
\hline 同 & $\equiv$ & & 57,589 & 172,643 & - & $i 72,643$ & 230,232 & : & - & - & 230,232 \\
\hline 同 & 四 & ，年 & 68,471 & 157,474 & & 157,474 & 225,945 & 14 & - & 4 & 225,941 \\
\hline 同 & 五 & & 122,428 & 68,684 & - & 68,684 & 191,112 & - & - & - & 191,112 \\
\hline 同 & 六 & 年 & 176,561 & 65,168 & - & 65,168 & 241,729 & - & - & - & 241,729 \\
\hline 同 & t & 年 & 215,250 & 27,890 & & 27,890 & 243,140 & - & - & - & 243,140 \\
\hline 同: & $\pi$ & & 285,013 & 38,794 &.$=$ & 38,794 & 323,807 & - & - & - & 323,807 \\
\hline 同 & 九 & 年 & 347,548 & 32,416 & $7: 6$ & 32,416 & 379,964 & - & - & - & 379,964 \\
\hline 同 & + & 年 & 412,600 & 44,551 & -1 & 44,551 & 457,151 & - & - & - & 457,151 \\
\hline 同 & + & & 487,162 & 37,515 & 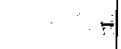 & 37,515 & 524,677 & - & - & - & 524,677 \\
\hline
\end{tabular}




\section{內地鋼材品種別需要額調}

其五 レール及フイツシュプレート

\begin{tabular}{|c|c|c|c|c|c|c|c|c|c|c|c|}
\hline \multirow{2}{*}{ 年 } & & \multirow{2}{*}{ 狄 } & \multirow{2}{*}{ 生硣頼 } & 输 & 移 & 顧 & \multirow{2}{*}{ 合 } & 輸 & 移 & 顆 & \multirow{2}{*}{$\begin{array}{l}\text { 差 引 } \\
\text { 需要頪 }\end{array}$} \\
\hline & & & & 签入額 & 移入額 & 解 & & 轵出制 & 移出顧 & 話 & \\
\hline 大 $\mathbb{E}$ & $\bar{\pi}$ & 年 & 67,846 & 66,185 & 暏 & - 66,185 & 134,031 & 些 & 2,054 & 2,054 & 131,977 \\
\hline 同 & 二 & 年 & 48,670 & 63,347 & - & 63,347 & 112,017 & - & 1,168 & 1,168 & 110,849 \\
\hline 同 $i$ & $\equiv$ & 年 & 67,308 & 28,551 & 19 & 28,570 & 95,878 & - & 1,254 & 1,254 & 94,624 \\
\hline 同 & 四 & 年 & 59,114 & 9,259 & 167 & 9,426 & 68,540 & 221 & 2,470 & 2,691 & 65,849 \\
\hline 同 & 五 & 年 & $51,70 \equiv$ & 4,558 & 18 & 4,576 & 56,284 & 161 & 2,179 & 2,340 & 53,944 \\
\hline 同. & 六 & 年 & 75,848 & 53,097 & 295 & 53,392 & 129,240 & 69 & 4,558 & 4,627 & 124,613 \\
\hline 同 & 七 & 年 & 65,976 & 67,773 & 104 & 67,877 & 133,853 & 3 & 4,672 & 4,675 & 129,178 \\
\hline 同 & $\lambda$ & 年 & 67,917 & 121,299 & - & 121,299 & 189,216 & 939 & 20,419 & 21,358 & 167,858 \\
\hline 同 & 九 & 年 & 56,876 & 116,071 & - & 116,071 & 172,947 & $: 44$ & 21,591 & 21,735 & 151,212 \\
\hline 同 & + & 年 & 49,859 & 60,094 & - & 60,094 & 109,953 & 1,259 & 9,768 & 11,027 & 98,926 \\
\hline 同 & +- & 年 & 65,474 & 181,066 & - & 181,066 & 246,540 & 1,284 & 21,992 & 23,276 & 223,264 \\
\hline 阔 & $+=$ & 年 & 96,187 & 124,822 & - & 124,822 & 221,009 & 359 & 25,912 & 26,271 & 194,738 \\
\hline 同 & $+\cdots$ & 年 & 82,965 & 107,461 & - & 107,461 & 190,426 & 2,616 & 8,991 & 11,607 & 178,819 \\
\hline 同 & $+R$ & 年 & 138,405 & 57,773 & - & 57,773 & 196,178 & 9,407 & 11,945 & 21,352 & 174,826 \\
\hline 昭 和 & 元 & 年 & 174,114 & 98,289 & - & 98,289 & 272,403 & 10,689 & 18,343 & 29,032 & 243,371 \\
\hline 间 & $=$ & 年 & 178,561 & 92,956 & - & 92,956 & 271,517 & 185 & 32,737 & 32,922 & 238,595 \\
\hline 同 & $\equiv$ & 年 & 213,064 & 47,640 & - & 47,640 & 260,704 & - & 26,360 & 26,360 & 234,344 \\
\hline 同 & 四 & 年 & 271,324 & 34,926 & - & $\cdot 34,926$ & 306,250 & - & 42,129 & 42,129 & 264,121 \\
\hline 同 & 五 & 年 & 289,696 & 13,147 & $\therefore$ & 13,147 & 302,843 & - & 37,334 & 37,334 & 265,509 \\
\hline 同 & 六 & 年 & 110,338 & 6.279 & - & 6,279 & 116,617 & -1 & 29,960 & 29,960 & 86,657 \\
\hline 同 & $t$ & 年 & 233,502 & 5,832 &. & 5,832 & 239,334 & - & 43,806 & 43,806 & $195,52 \mathbf{0}$ \\
\hline 同 & 八 & 年 & 271,982 & 3,994 & - & 3,994 & 275,976 & - & 52,204 & 52,204 & 223,772 \\
\hline 同 & 九 & 年 & 368,199 & 6,979 & -1 & 6,979 & 375,178 & 95,453 & 61,018 & $156,47 \mathrm{t}$ & 218,707 \\
\hline 同 & + & & 366,744 & 19,286 & - & 19,286 & 386,030 & 100,200 & 99,207 & 199,407 & 186,623 \\
\hline 同 & -F - & 年 & 288,536 & $\cdot 48,508$ & - & 48,508 & 337,044 & 30,010 & 93,686 & 123,696 & 213,348 \\
\hline
\end{tabular}

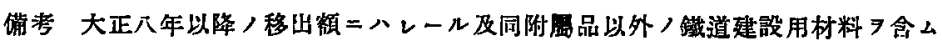


其六筒 及 管

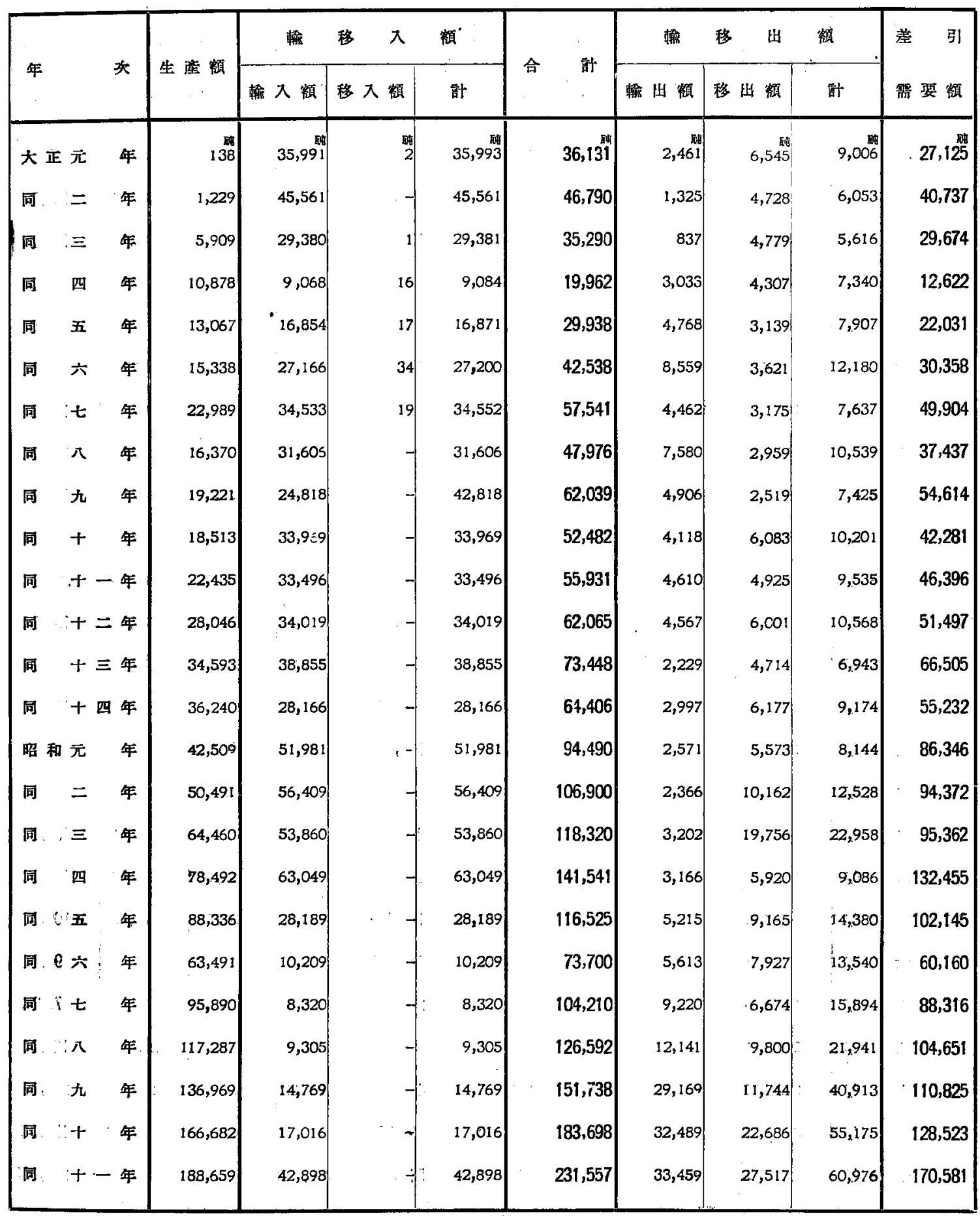

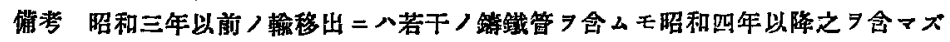


其 七 其 他

\begin{tabular}{|c|c|c|c|c|c|c|c|c|c|c|c|}
\hline \multirow{2}{*}{ 年 } & & \multirow{2}{*}{ 次 } & \multirow{2}{*}{ 生虑顧 } & \multicolumn{3}{|c|}{ 移 } & \multirow{2}{*}{ 就 } & \multicolumn{2}{|r|}{ 移 } & \multirow{2}{*}{$\frac{\text { 額 }}{\text { 就 }}$} & \multirow{2}{*}{$\begin{array}{l}\text { 差 } \\
\text { 需要頑 }\end{array}$} \\
\hline & & & & 輸入䪼 & 移入糆 & 計 & & 稀出颣 & 移出額 & & \\
\hline 大 正 & 元 & 年 & 21,226 & 158,870 & 敬 & 158,904 & 180,130 & 5,682 & 10,855 & 26,537 & 163,593 \\
\hline 同 & $=$ & 年 & 44,889 & 107,362 & 12 & 107,374 & 152,263 & 9,300 & 8,641 & 17,941 & 134,322 \\
\hline 同 & $\equiv$ & 年 & 55,272 & 66,958 & 7. & 66,965 & 122,237 & 9,785 & 6,294 & 16,079 & 106,158 \\
\hline 同 & 四 & 年 & 58,177 & 40,899 & 59 & 40,958 & 99,135 & 6,749 & 6,010 & 12,759 & 86,376 \\
\hline 同 & 五 & 年 & 82,087 & 57,754 & 106 & 57,860 & 139,947 & 3,739 & 3,487 & 7,226 & 132,721 \\
\hline 同 & 六 & 年 & 114,476 & 45,422 & 73 & 45,495 & 159,971 & 11,128 & 3,904 & 15,032 & 144,939 \\
\hline 同 & $t^{\prime}$ & 年 & 103,281 & 58,923 & 150 & 59,073 & 162,354 & 10,519 & 4,496 & 15,015 & 147,339 \\
\hline 同 & 八 & 年 & 113,779 & 61,764 & 107 & 61,871 & 175,650 & 21,790 & 7,847 & 29,637 & 146,013 \\
\hline 同 & 九 & 年 & 92,958 & 93,614 & 47 & 93,661 & 186,619 & 11,644 & 11,524 & 23,168 & 163,451 \\
\hline 同 & + & 年 & 92,241 & 92,839 & 119 & 922958 & 185,199 & 2,960 & 19,788 & 22,748 & 162,451 \\
\hline 同 & +- & 年 & 97,918 & 123,116 & 540 & 123,656 & 221,574 & 2,569 & 15,763 & 18,332 & 203,242 \\
\hline 同 & $+=$ & 年 & 84,898 & 86,299 & 674 & 86,973 & 171,871 & 903 & 20,865 & 21,768 & 150,103 \\
\hline 同 & $+\equiv$ & 年 & 84,641 & 148,599 & 1,081 & 149,680 & 234,321 & 2,746 & 21,316 & 24,062 & 210,259 \\
\hline 同 & + 四 & 年 & 96,065 & 48,144 & 1,245 & 49,389 & 145,454 & $4 ; 755$ & 20,367 & 25,122 & $\uparrow 20,33$ \\
\hline 昭 和 & 元 & 年 & 100,347 & 65,610 & 1,404 & 67,014 & 167,361 & 2,315 & 24,519 & 26,834 & 140,527 \\
\hline 同 & $=$ & 年 & 113,345 & 45,620 & 2,638 & 48,258 & 161,603 & 3,160 & 37,069 & 40,229 & 121,374 \\
\hline 同 & $\equiv$ & 年 & 145,312 & 61,557 & 1,903 & 63,460 & 208,772 & 5,090 & 43,724 & 48,814 & $\{59,958$ \\
\hline 同 & 四 & 年 & 132,251 & 88,650 & 4,561 & 93,211 & 225,462 & 6,933 & 42,141 & 49,074 & 176,388 \\
\hline 同 & 五 & 年 & 115,694 & 67,306 & 2,126 & 69,432 & 185,126 & 42,238 & 33,885 & 76,123 & 109,003 \\
\hline 同 & 六 & 年 & 82,571 & 64,928 & 2,076 & 67,004 & 149,575 & 11,143 & 44,755 & 55,898 & 93,677 \\
\hline 同 & $t$ & 年 & 138,215 & 62,993 & 5,042 & 68,035 & 206,250 & 73,514 & 57,363 & 130,877 & 75,373 \\
\hline 同 & 八 & 年 & 229,271 & 98,907 & 9,484 & 108,391 & 337,662 & 153,782 & 59,810 & 213,592 & 124,070 \\
\hline 同 & 九 & 年 & 272,398 & 95,605 & 36,307 & 131,912 & 404,310 & 79,440 & 70,283 & 149,723 & 254,587 \\
\hline 同 & + & & 349,300 & 74,003 & 4,289 & 78,292 & 427,592 & 192,829 & 82,118 & 274,947 & 152,645 \\
\hline 同 & +- & & 454,798 & 48,063 & $10,7: 74$ & 58,837 & 513,635 & 170,462 & 135,772 & 306,234 & 207,401 \\
\hline
\end{tabular}




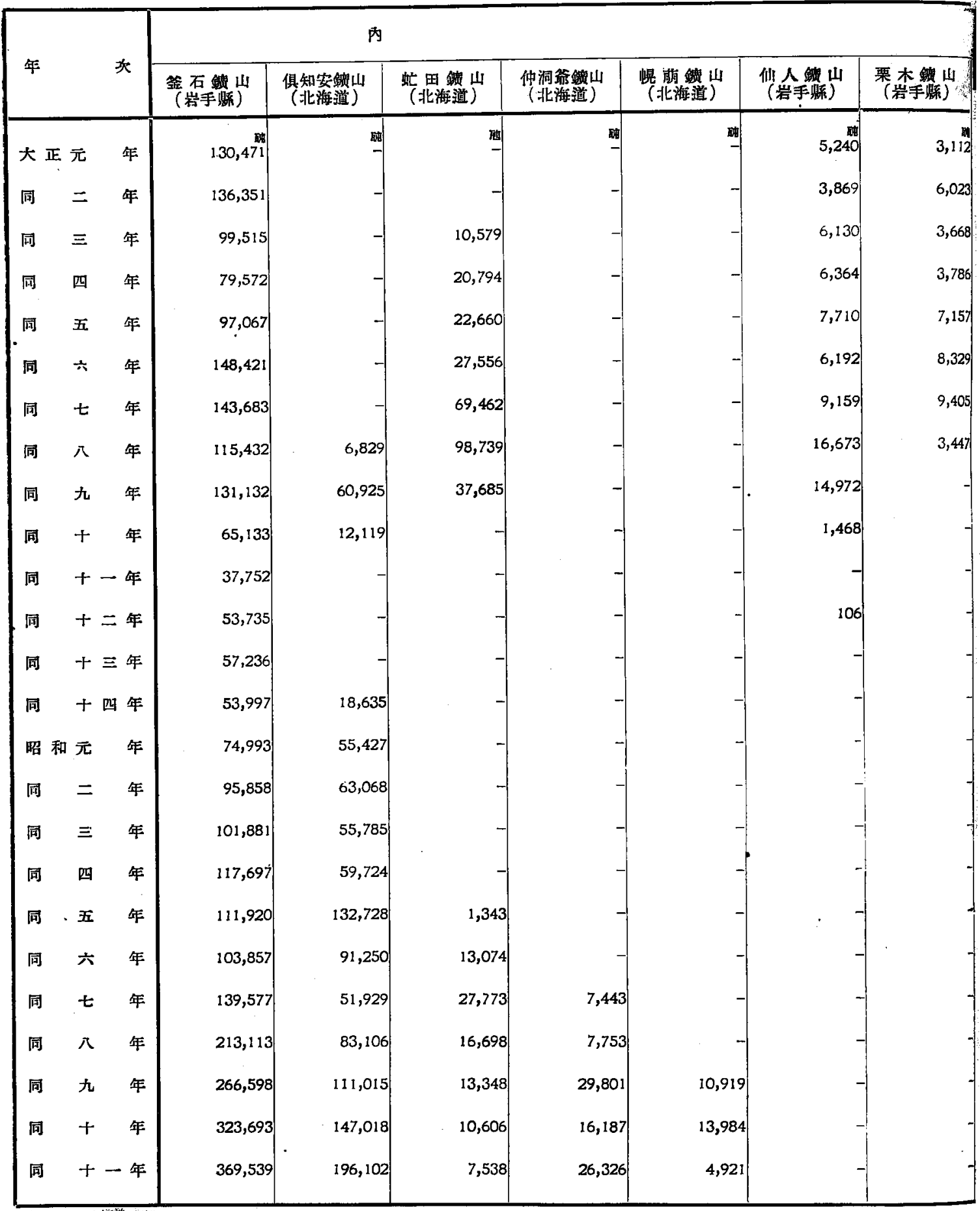


出額調

\begin{tabular}{|c|c|c|c|c|c|c|c|c|}
\hline \multicolumn{2}{|l|}{ 地 } & \multirow{2}{*}{ 触 } & \multicolumn{2}{|l|}{ 沙 } & 洲 & \multirow{2}{*}{ 訫 } & \multirow{2}{*}{ 砂 } & \multirow{2}{*}{ 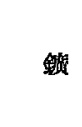 } \\
\hline 其他 / 鑲山 & 計 & & 䏝 & 富 & 壾 & & & \\
\hline 14,160 & 152,983 & 122,503 & 明 & at & 跑 & 275,486 & & 18,201 \\
\hline 6,858 & 153,101 & 142,049 & & $\widehat{\approx}$ & & 295,150 & & 18,600 \\
\hline 1,744 & 121,636 & 182,034 & & & & 303,670 & & 14,784 \\
\hline 8,439 & 118,955 & 209,937 & & & & 328,892 & & 17,200 \\
\hline 5,359 & 139,953 & 245,418 & & & & 385,371 & & 18,902 \\
\hline 77,096 & 267,594 & 152,933 & 3,585 & 99,561 & 103,146 & 523,673 & & 34,035 \\
\hline 146,405 & 378,114 & 430,787 & 77,010 & 112,347 & 189,357 & 998,258 & & 37,948 \\
\hline 121,829 & 362,949 & 417,000 & 133,695 & 130,170 & 263,865 & $1,043,814$ & & 27,523 \\
\hline 70,144 & 314,858 & 447,249 & 14,862 & 161,104 & 175,966 & 938,073 & & 9,134 \\
\hline 8,257 & 86,977 & 232,692 & 1,748 & 204,495 & 206,243 & 525,912 & & 6,878 \\
\hline 1,992 & 39,744 & 185,584 & 600 & 139,528 & 140,128 & 365,456 & & 6,067 \\
\hline 1,333 & 55,174 & 305,255 & - & 213,731 & 213,731 & 575,160 & & 3,799 \\
\hline 686 & 57,922 & 323,636 & - & 220,384 & 220,384 & 601,942 & & 3,118 \\
\hline 3,133 & 75,765 & 376,207 & 22,240 & 198,759 & 220,999 & 672,971 & & 3,459 \\
\hline & 130,420 & 387,717 & 377,233 & 189,310 & 566,543 & $1,084,680$ & & 4,469 \\
\hline 79 & 159,005 & 422,560 & 457,300 & 173,304 & 630,604 & $1,212,169$ & & 12,301 \\
\hline 40 & 157,706 & $559 ; 331$ & $488 ; 000$ & 185,624 & 673,624 & $1,390,661$ & & 1,869 \\
\hline 135 & 177,556 & 559,218 & 529,490 & 251,768 & 781,258 & $1,518,032$ & & 259 \\
\hline & 245,991 & 581,960 & 523,894 & 359,603 & 883,497 & $1,711,448$ & & 780 \\
\hline & 208,181 & 415,676 & 673,380 & 250,879 & 924,259 & $1,548,116$ & & 629 \\
\hline & 226,722 & 376,371 & 742,810 & 237,068 & 979,878 & $1,582,971$ & & 4,544 \\
\hline & 320,670 & 522,553 & 770,381 & 328,032 & $1,098,413$ & $1,941,636$ & & 1,097 \\
\hline & 431,681 & 570,464 & 739,623 & 393,748 & $1,133,371$ & $2,135,516$ & & 2,260 \\
\hline 4,377 & 515,865 & 598,109 & 985,480 & 492,460 & $1,477,940$ & $2,591,914$ & & 5,902 \\
\hline 16,023 & 620,449 & 629,128 & $1,325,219$ & 579,374 & $1,904,593$ & $3,154,170$ & & 4,253 \\
\hline
\end{tabular}




\section{鉄 鐵 生 產 額 調}

\begin{tabular}{|c|c|c|c|c|c|c|c|c|c|c|c|}
\hline \multirow{2}{*}{ 年 } & \multirow{2}{*}{\multicolumn{2}{|c|}{ 次 }} & \multicolumn{2}{|c|}{ 内 } & \multicolumn{3}{|c|}{ 地 } & 朝 解 & 漰 洲 & \multirow{2}{*}{ 就 } & \multirow{2}{*}{ 合 } \\
\hline & & & $=-ク$ ス魮 & 木炭 鈋 & 再裴 鈋 & 其 他 & 計 & ニークス鈚 & コークス銚 & & \\
\hline 大 正 & 元 & 年 & it & & 矿 & 此 & 237,755 & 暗 & 剧 & 政 & 237,755 \\
\hline 同 & $=$ & 年 & - & & 不 & & 240,363 & - & - & - & 240,363 \\
\hline 同 & $\equiv$ & 年 & & & & & 300,221 & - & $\dot{-}$ & - & 300,221 \\
\hline 同 & 四 & 年 & & & 菲 & & 317,748 & - & 29,909 & 29,909 & 347,657 \\
\hline 同 & 五 & 年 & & & & & 388,591 & - & 49,022 & 49,022 & 437,713 \\
\hline 同 & 六 & 年 & 411,289 & 18,199 & 21,154 & & 450,642 & - & 38,610 & 38,610 & 489,252 \\
\hline 同 & 七 & 年 & 446,703 & 37,492 & 98,563 & & 582,758 & 42,698 & 45.712 & 88,410 & 671,169 \\
\hline 同 & 八 & 年 & 520,149 & 46,971 & 28,398 & & 595,518 & 78,384 & 106,082 & 184,466 & 779,984 \\
\hline 同 & 九 & 年 & 443,953 & 31,192 & 45,891 & & 521,036 & 84,118 & 116,037 & 200,155 & 721,191 \\
\hline 同 & + & 年 & 431,881 & 12,719 & 28,125 & & 472,725 & 83,010 & 93,951 & 176,961 & 649,686 \\
\hline 同 & +- & 年 & 532,131 & 3,120 & 15,594 & & 550,845 & 83,179 & 59,842 & 143,021 & 693,86 \\
\hline 同 & $+=$ & 年 & 588,113 & - & 11,585 & & 599,698 & 99,933 & 97,849 & 197,782 & 797,480 \\
\hline 同 & $+三$ & 年 & 578,549 & 270 & 6,964 & 268 & 586,051 & 99,795 & 134,376 & 234,171 & 820,222 \\
\hline 同 & 十四 & 年 & 676,879 & 153 & 8,146 & - & 685,178 & 99,160 & 136,685 & 235,845 & 921,023 \\
\hline 昭 和 & 元 & 年 & 799,483 & - & 10,141 & - & 809,624 & 115,036 & 198.143 & 313,179 & $1,122,803$ \\
\hline 同 & $=$ & 年 & 884,341 & - & 10,905 & 925 & 896,171 & 129,022 & 244,203 & 373,225 & $1,269,396$ \\
\hline 同 & $\Xi$ & 年 & $1,077,065$ & 381 & 14,237 & 853 & $1,092,536$ & 146,159 & 284,675 & 430,834 & $1,523,370$ \\
\hline 同 & 四 & 年 & $1,065,908$ & 2,000 & 19,138 & 82 & $1,087,128$ & 153,627 & 295,380 & 449,007 & $1,536,135$ \\
\hline 同 & 五 & 年 & $1,136,853$ & 241 & 24,743 & 57 & $1,161,894$ & 150,524 & 349,415 & 499,939 & $1,661,833$ \\
\hline 同 & 六 & 年 & 896,445 & - & 20,897 & - & 917,342 & 147,257 & 342,270 & 489,527 & $1,406,869$ \\
\hline 同 & t & 年 & 993,447 & 1,253 & 15,837 & 224 & $1,010,761$ & 161,940 & 368,181 & 530,121 & $1,540,882$ \\
\hline 同 & 八 & 年 & $1,403,502$ & - & 32,717 & 463 & $1,436,682$ & 161,163 & 433,523 & 594,686 & $2,031,368$ \\
\hline 闻 & 九 & 年 & $1,686,641$ & 3,368 & 37,222 & 927. & $1,728,158$ & 210,807 & 475,826 & 686,633 & $2,414,791$ \\
\hline 同 & + & 年 & $1,864,573$ & 5,851 & 35,374 & 989 & $1,906,787$ & 211,441 & 607,948 & 819,389 & $2,726,176$ \\
\hline 同 & $+\rightarrow$ & 年 & $1,972,082$ & 6,039 & 29,311 & 139 & $2,007,571$ & 216,751 & 633,432 & 850,183 & $2,857,754$ \\
\hline
\end{tabular}

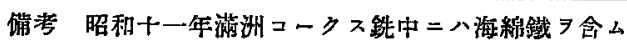


フエロアロイ生產額調

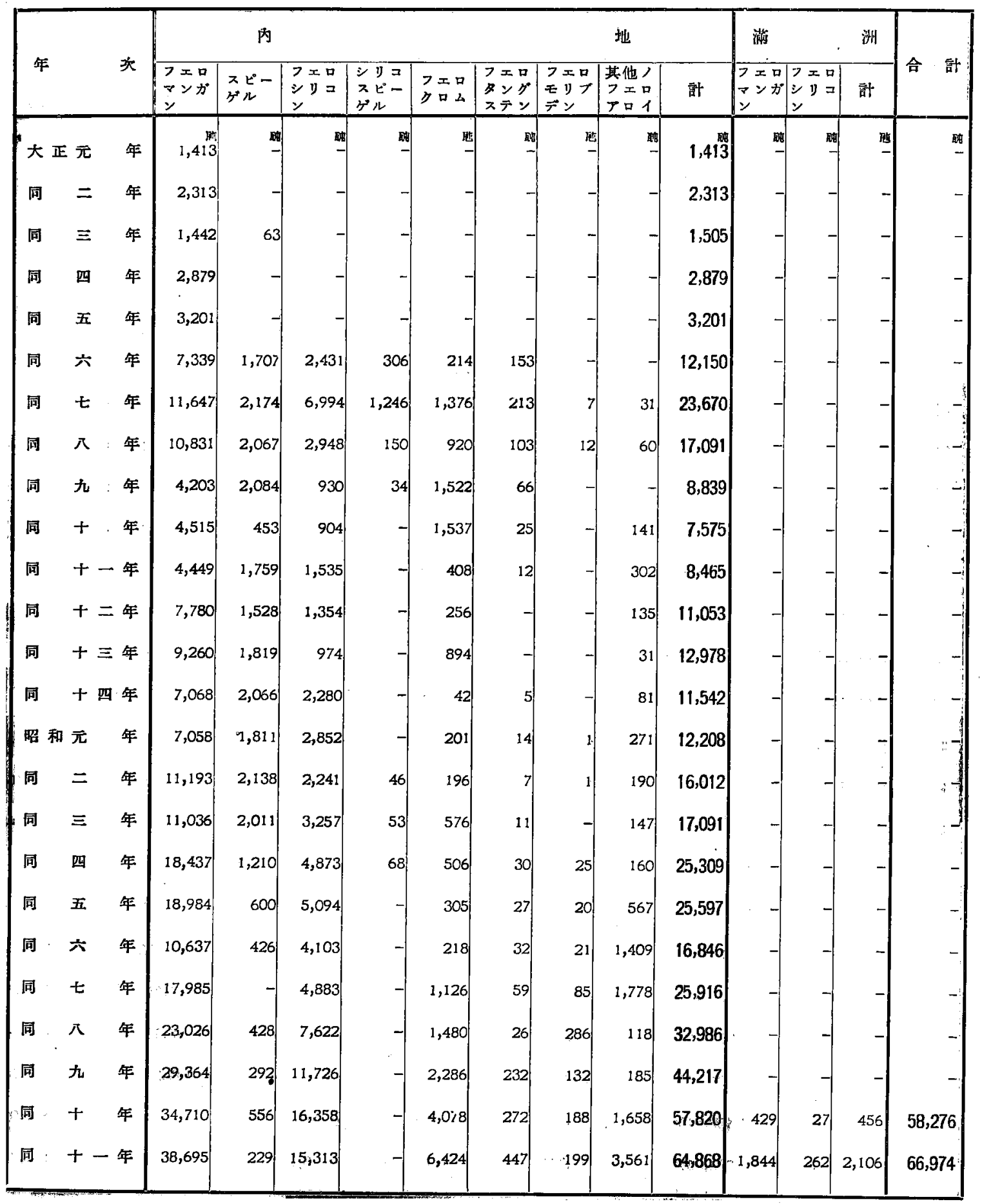


鋼

生

產

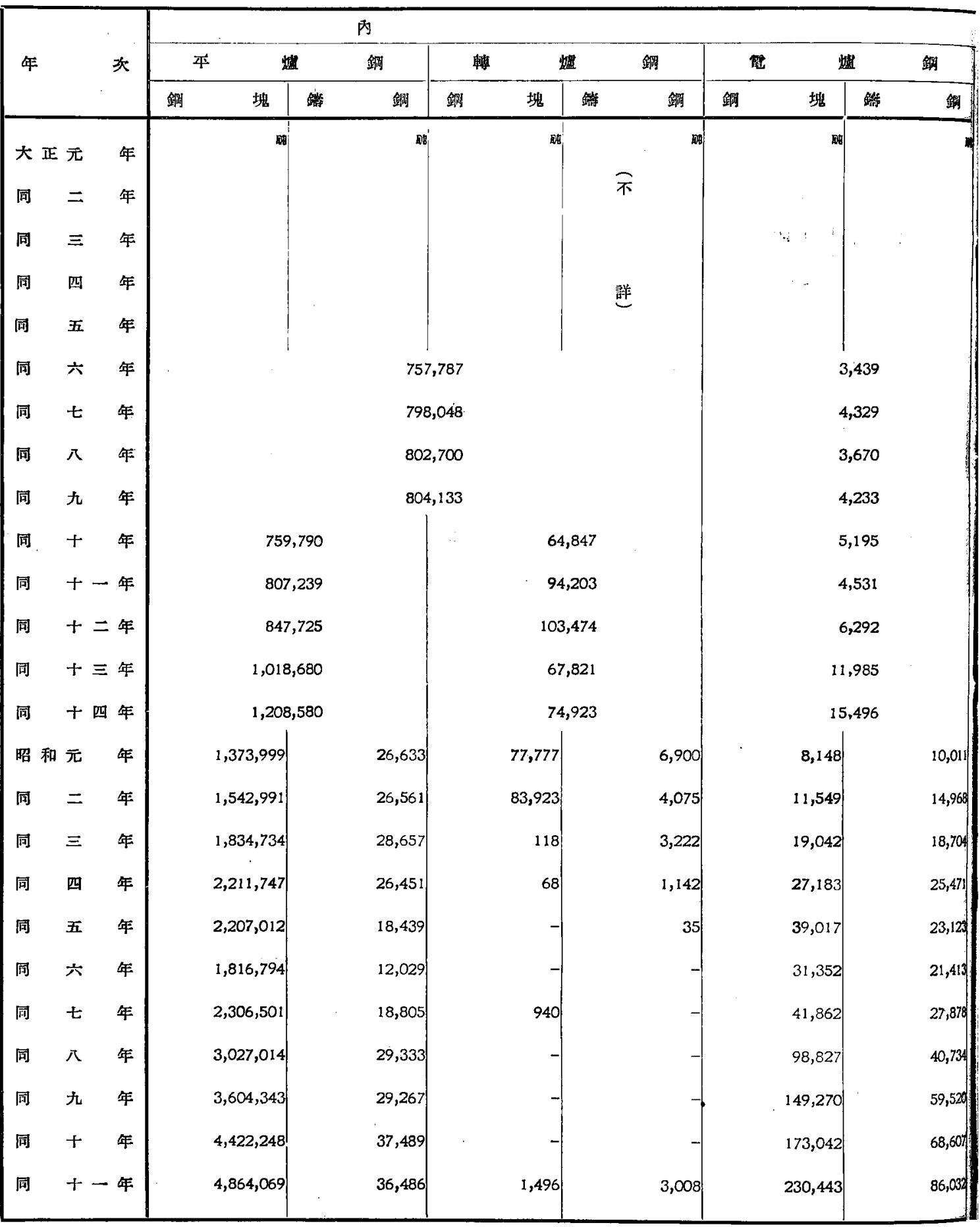


額

調

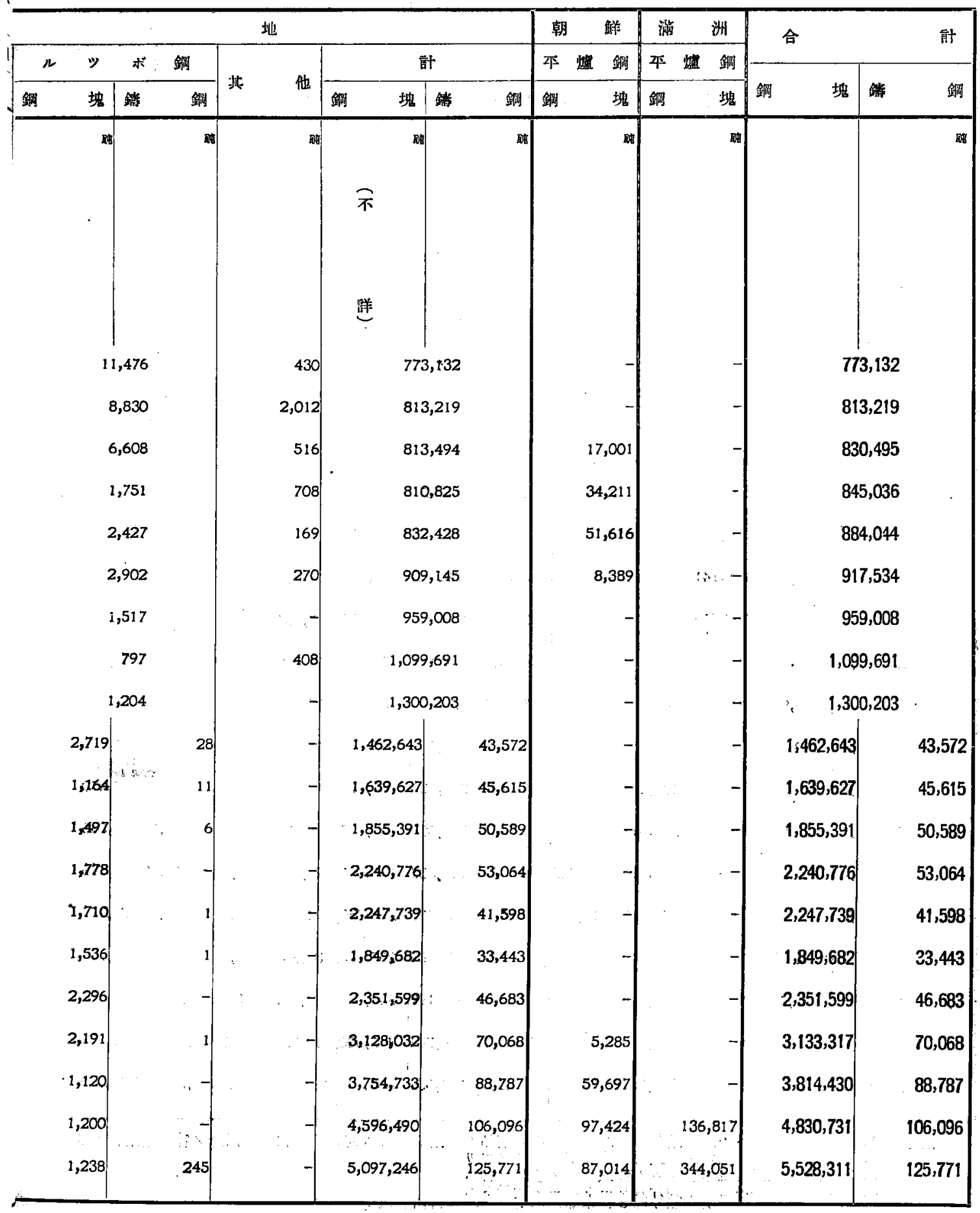




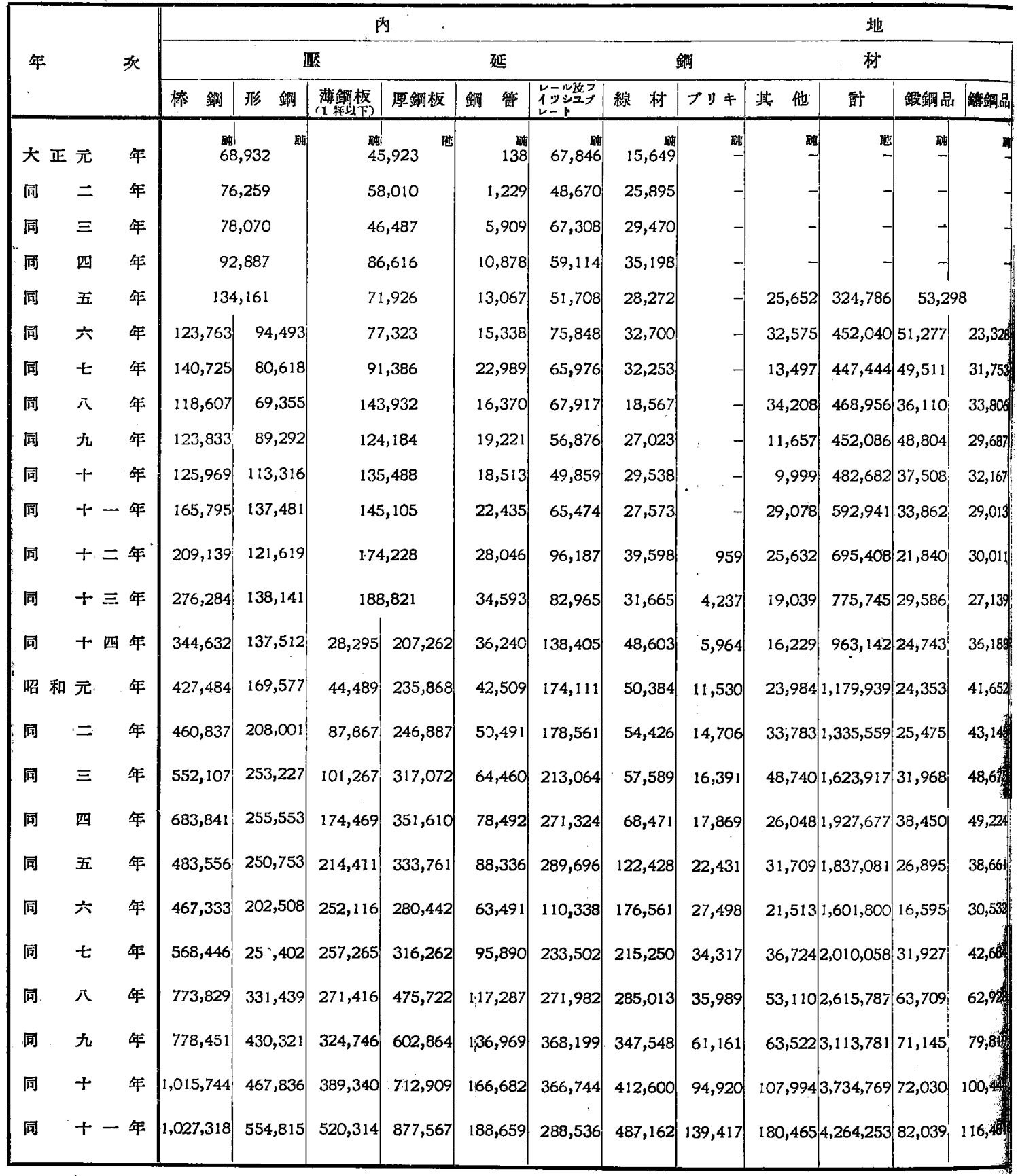

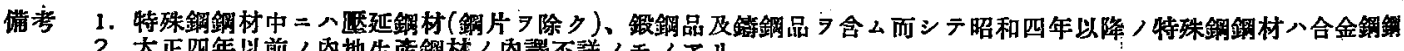

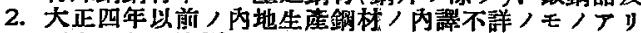

3. 昭和品年以降庭延銅材中=八伸鐵業者ノ製品 $\exists$ 含么

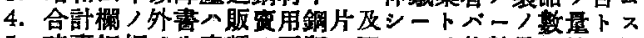

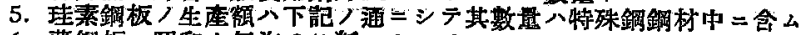

6. 䔦鎦板八昭和十年远 0.7 粍 7 ト 大正十四年

201

昭和元年

643

昭和二年

昭和三年

3,390

昭和四年

昭和五年

5,349

昭和六年

昭和七年

$3,244 \quad 9,737$ 
產 額 調

\begin{tabular}{|c|c|c|c|c|c|c|c|c|c|c|c|c|c|}
\hline \multirow{3}{*}{$\begin{array}{l}\text { 特珠鋼 } \\
\text { 鎆 材 }\end{array}$} & & \multicolumn{3}{|c|}{ 朝 } & \multicolumn{2}{|c|}{ 能 } & \multicolumn{2}{|l|}{ 糊 } & \multicolumn{4}{|r|}{ 洲 } & \multirow{3}{*}{ 總 } \\
\hline & \multirow{2}{*}{ 計 } & \multicolumn{2}{|c|}{ 憠 } & 延 & \multicolumn{2}{|l|}{ 鋼 } & \multirow{2}{*}{ 鋼 } & \multirow{2}{*}{ レール } & \multirow{2}{*}{ I溥龬板 } & \multirow{2}{*}{ 厚鋼板 } & \multirow{2}{*}{ 㵄龬品 } & \multirow{2}{*}{ 壾 } & \\
\hline & & 棒鍓 & 形鋼 & 原㖉板板 & $2-n$ & 計 & & & & & & & \\
\hline & 219,714 & 蚂 & & 奛 & 别 & 明 & 盹 & 䐓 & 㽖 & at & 㽖 & 䏛 & 219,714 \\
\hline - & 254,952 & - & - & - & - & - & - & - & - & - & - & - & 254,952 \\
\hline- & 282,516 & - & - & $\rightarrow$ & - & - & - & - & - & - & - & - & 282,516 \\
\hline & 342,870 & & - & - & - & - & - & - & & - & - & - & 342,870 \\
\hline 3,137 & 381,221 & - & - & - & - & - & - & -1 & - & - & - & - & 381,221 \\
\hline 7,296 & 533,941 & - & - & - & - & - & - & - & - & - & - & - & 533,941 \\
\hline 8,520 & 537,228 & & - & & - & - & - & - & - & - & - & - & 537,228 \\
\hline 9,655 & 548,527 & 3,222 & - & 1,362 & - & 4,584 & - & - & - & - & - & - & 553,111 \\
\hline 2,810 & 533,387 & 3,628 & & $\mid 21,817$ & 974 & 26,419 & - & - & - & - & - & - & 559,806 \\
\hline 12,567 & 564,924 & & 2,312 & 27,714 & - & 30,026 & - & - & - & - & - & - & 594,950 \\
\hline 5,965 & 661,781 & - & 2,359 & 7,053 & - & 9,412 & . & - & - & - & - & - & 671,193 \\
\hline 7,415 & $\begin{array}{r}754,674 \\
\text { 外 } \\
66,390\end{array}$ & _ & & & - & - & & - & & - & - & - & 754,674 \\
\hline 8,877 & $\begin{array}{r}841,347 \\
\text { 外 } \\
77,165\end{array}$ & - & & & - & - & & - & & - & - & - & 841,347 \\
\hline 18,905 & 外 $\begin{array}{l}1,042,978 \\
84,662\end{array}$ & - & & & - & - & & - & & - & - & - & $1,042,978$ \\
\hline 10,358 & $\begin{array}{r}1,256,302 \\
\text { 外 } 85,908\end{array}$ & & & - & & - & & & & & & - & $1,256,302$ \\
\hline 10,942 & $\begin{array}{r}1,415,121 \\
69,479\end{array}$ & - & _ & - & - & - & & 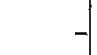 & & & - & - & $1,415,121$ \\
\hline 15,929 & $\begin{array}{r}1,720,489 \\
\text { 外 } 68,585\end{array}$ & - & & - & - & - & & - & & & - & - & $1,720,489$ \\
\hline 18,529 & $\begin{array}{r}2,033,880 \\
\times \quad 101,559\end{array}$ & - & & & . & - & & _- & - & 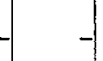 & - & - & $2,033,880$ \\
\hline 18,429 & $\begin{array}{r}1,921,066 \\
75,338\end{array}$ & - & & - & & - & & _ & - & - & - & - & $1,921,066$ \\
\hline 13,931 & $\begin{array}{r}1,662,858 \\
153,875\end{array}$ & & & & 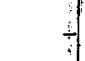 & - & & & & - & - & - & $1,662,858$ \\
\hline 27,929 & $\begin{array}{r}2,112,598 \\
\quad 213,971\end{array}$ & & & & 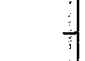 & - & & & & + & & - & $2,112,598$ \\
\hline 49,524 & $\begin{array}{r}2,791,948 \\
\text { o } 194,818\end{array}$ & & & & - & - & & & _ & & - & - & $2,791,948$ \\
\hline 57,912 & $\begin{array}{r}3,322,657 \\
9 k \\
269,413\end{array}$ & & & 21,619 & - & 21,619 & & & & - & - & - & $3,344,276$ \\
\hline 68,832 & $\begin{array}{r}3,976,075 \\
319,829\end{array}$ & & 13,603 & 38,229 & - & 51,832 & 12,346 & 8,397 . & 4,704 & & - & 25,447 & $4,053,354$ \\
\hline 75,813 & $\begin{array}{r}4,538,586 \\
\text { \& } \quad 479,952\end{array}$ & & 17,634 & 38,978 & & 56,612 & 67,287 & 38,228 & 29,14 ! & 498 & 152 & 135,306 & $4,730,504$ \\
\hline
\end{tabular}

材ノ数量ニシテ高炭粠銅等 $シ$ 含マズ 
シ”一クス及副

(其

\begin{tabular}{|c|c|c|c|c|c|c|c|c|}
\hline \multirow{2}{*}{ 鲜 } & 昭 & 和 & \multicolumn{2}{|r|}{ 年 } & 昭 & 和 & + & 年 \\
\hline & 内 地 & 朝 “的 & 滿洲 & 暗 & 地 & 鮮 & 淽 洲 & 合 解 \\
\hline$=-\eta x$ & $1,940,326$ & 205204 & 735,787 & $2,881,317$ & $1,833,486$ & 201,840 & 654,038 & $2,689,364$ \\
\hline 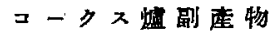 & & & & & & & & \\
\hline 粉 $=-\eta x$ & 99,737 & 7,145 & 117,447 & 224,329 & 92,629 & 7,299 & 78,433 & 178,361 \\
\hline 酼酸 & 30,857 & 3,393 & 11,779 & 46,029 & 29,266 & 3,077 & 9,791 & 42,134 \\
\hline$-\quad n$ & 121,901 & 10,450 & 39,919 & 172,270 & 125,208 & 11,405 & 30,039 & 166,652 \\
\hline$\check{ン} ン \forall-ル$ & 22,692 & 1,987 & 6,550 & 31,229 & 22,374 & 2,091 & 4,405 & 28,870 \\
\hline$r n t-n$ & 1,380 & 15 & - & 1,395 & 1,379 & 4 & - & 1,383 \\
\hline$\neq \equiv \square-n$ & 20 & - & - & 20 & 17 & - & - & 17 \\
\hline ソルベントナフサ & 1,023 & 82 & -1 & 1,105 & 1,125 & 93 & - & 1,218 \\
\hline ヘビーナフサ & 42 & - & -1 & 42 & 58 & - & (x) & 58 \\
\hline$ナ>\geqslant y$ У & 6,608 & 1,026 & 1,420 & 9,054 & 6,213 & 1,020 & 835 & 8,068 \\
\hline$\Rightarrow 2 y-n$ & 769 & - & - & 769 & 2,072 & - & - & 2,072 \\
\hline クレオンート油 & 27,278 & 1,864 & 7,827 & 36,969 & 27,370 & 2,359 & 6,667 & 36,396 \\
\hline アンス & 1,570 & 289 & 480 & 2,342 & 1,757 & - & & 1,757 \\
\hline $\mathfrak{E}^{\circ}$ & 64,890 & 6,576 & 18,119 & 89,585 & 67,408 & 7,700 & 15,238 & 90,346 \\
\hline ピッチコーク & 4,548 & -1 & - & 4,548 & 4,036 & - & - & 4,036 \\
\hline 石 炭 酸 & 314 & - & - & 314 & 278 & - & - & 278 \\
\hline 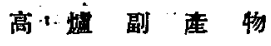 & & & & & & & & \\
\hline 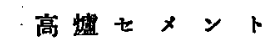 & 159,878 & - & 1,392 & 161,270 & 111,150 & - & 2,100 & 113,250 \\
\hline 鑟 & 3,326 & - & - & 3,326 & 2,443 & - & & 2,443 \\
\hline 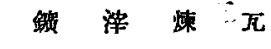 & 133,036 & 1,291 & 50,433 & 184,760 & 131,078 & 5,474 & 47,571 & 184,123 \\
\hline 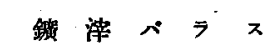 & 165,547 & & & $165 ;$; & 233;880 & & & 233,880 \\
\hline 鑜涬ターペラス & & - & - & - & & - & & \\
\hline
\end{tabular}

请考 本表（22頁乃至25面）八鉄鐵製造=体フモ， 


\section{產物生產額，調}

-)

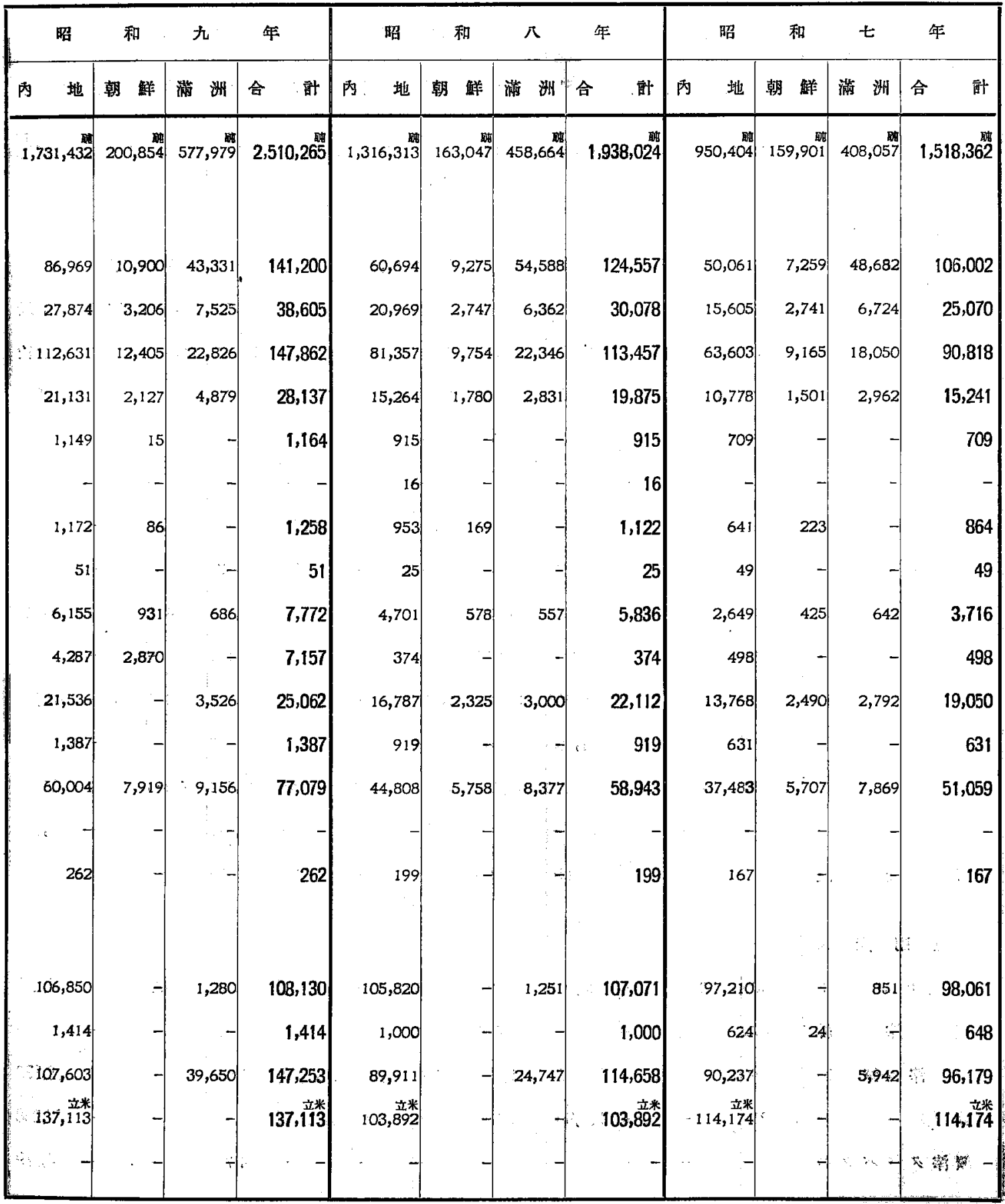




\section{コ一クス㞋副}

\section{(其}

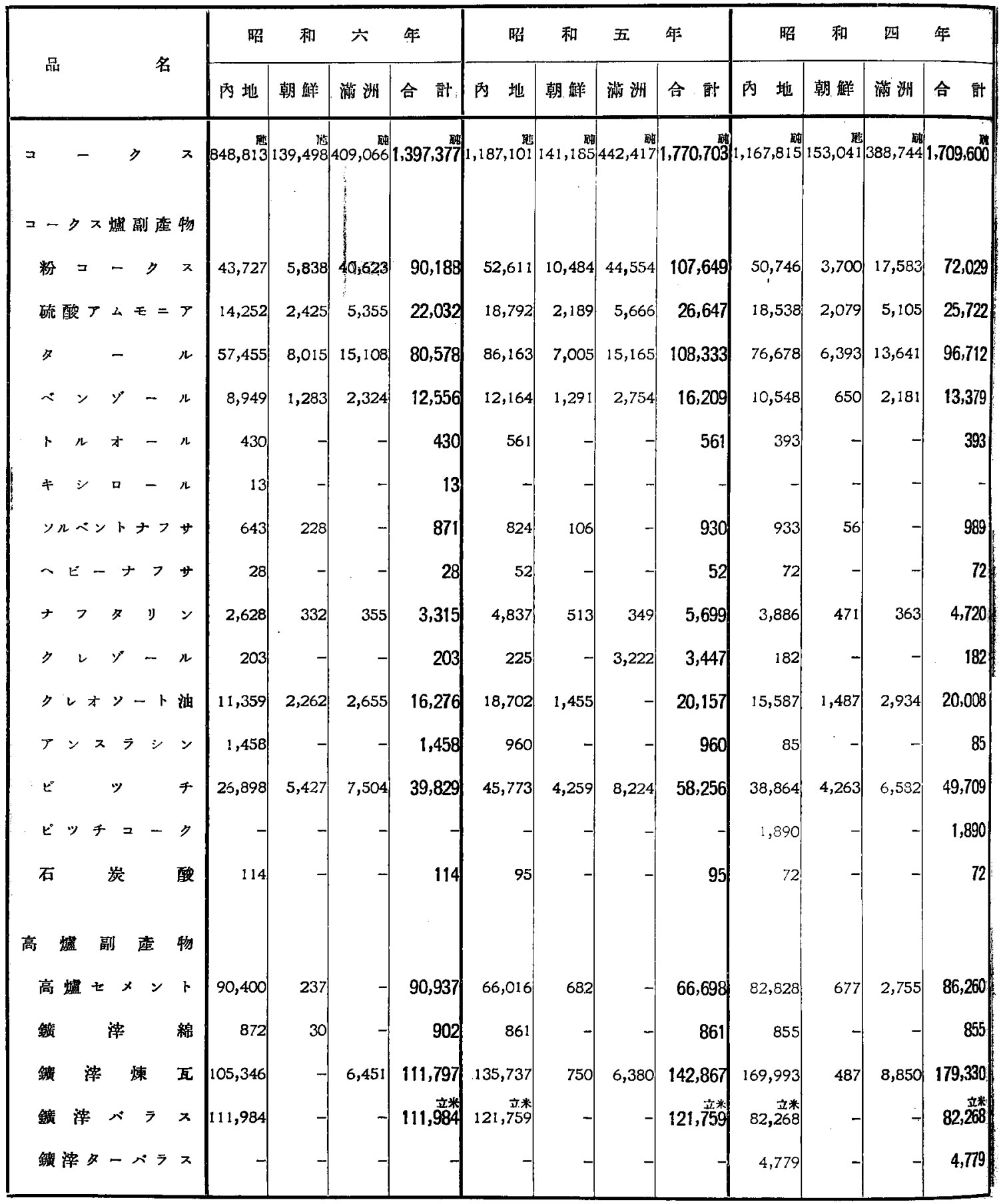




\section{產物生產額調}

\section{二)}

\begin{tabular}{|c|c|c|c|c|c|c|c|c|c|c|c|}
\hline 昭 & 和 & $\equiv$ & 年 & 炤 & 和 & $=$ & 年 & 昭 & 和 & 元 & 年 \\
\hline 地 & 朝 鮮 & 漰 洲 & 詁 & 地 & 朝 鲜 & 满 洲 & 計 & 地 & 潮 鮮 & 满 洲 & 誨 \\
\hline $1,098,134$ & 146,624 & 342,241 & $1,586,999$ & $1,033,543$ & 130,356 & 310,290 & $1,474,189$ & 846,633 & 113,152 & 271,455 & $1,231,240$ \\
\hline 46,754 & 4,603 & 15,146 & 66,503 & 61,919 & - & 18,595 & 80,514 & 44,153 & 6,686 & 12,324 & 63,163 \\
\hline 17,911 & 1,632 & 4,925 & 24,468 & 16,318 & 1,434 & 4,406 & 22,158 & 13,771 & 1,503 & 2,778 & 18,052 \\
\hline 73,318 & 5,556 & 13,266 & 92,140 & 68,194 & 639 & 11,457 & 80,290 & 58,372 & 5,389 & 8,461 & 72,222 \\
\hline 9,660 & -1 & 1,783 & 11,443 & 9,679 & - & 1,681 & 11,360 & 7,383 & $\cdots$ & 718 & 8,101 \\
\hline 412 & - & & 412 & 472 & - & & 472 & 254 & - & - & 254 \\
\hline 11 & - & - & 11 & - & - & - & - & 12 & - & - & 12 \\
\hline 858 & -1 & - & 858 & 541 & - & - & 541 & 553 & - & 15 & 568 \\
\hline 54 & - & - & 54 & 43 & - & - & 43 & 34 & - & - & 34 \\
\hline 3,520 & - & 405 & 3,925 & 3,684 & 403 & 148 & 4,235 & 2,966 & 391 & 40 & 3,397 \\
\hline 110 & - & & 110 & 92 & - & - & 92 & 62 & - & - & 62 \\
\hline 17,401 & - & 2,766 & 20,167 & 17,708 & -1 & 2,063 & 19,771 & 16,658 & - & 1,440 & 18,098 \\
\hline & -1 & & 26 & 14 & - & - & 14 & 15 & - & 11 & 26 \\
\hline 36,210 & - & & 36,210 & 39,068 & 2,872 & 5,847 & 47,787 & 31,518 & 2,374 & 4,626 & 38,518 \\
\hline 1,378 & 3,533 & 6,556 & 11,467 & 991 & - & - & 991 & 370 & - & - & 370 \\
\hline 65 & & & 65 & & - & - & - & 57 & & - & 57 \\
\hline 50,216 & 499 & 1,257 & 51,972 & 22,514 & 311 & 1,859 & 24,684 & 20,150 & 294 & 3,783 & 24,227 \\
\hline 937 & - & & ' 937 & 738 & - & - & 738 & 703 & - & - & 703 \\
\hline 123,496 & 302 & 8,393 & 132,191 & 46,055 & 291 & 6,466 & 70,812 & 85,907 & 688 & 4,650 & 91,245 \\
\hline 62 立* & - & & 62,832 & 50, 咅米 & - & & 50,728 & $35, \begin{array}{c}\text { 辛米 } \\
3575\end{array}$ & & - & 35,575 \\
\hline 1,181 & & & 1,181 & & - & & & & & - & $\begin{array}{lll}- & \\
-1\end{array}$ \\
\hline
\end{tabular}




\section{鉎鐵主要製鐵所別生產額調}

（其 一)

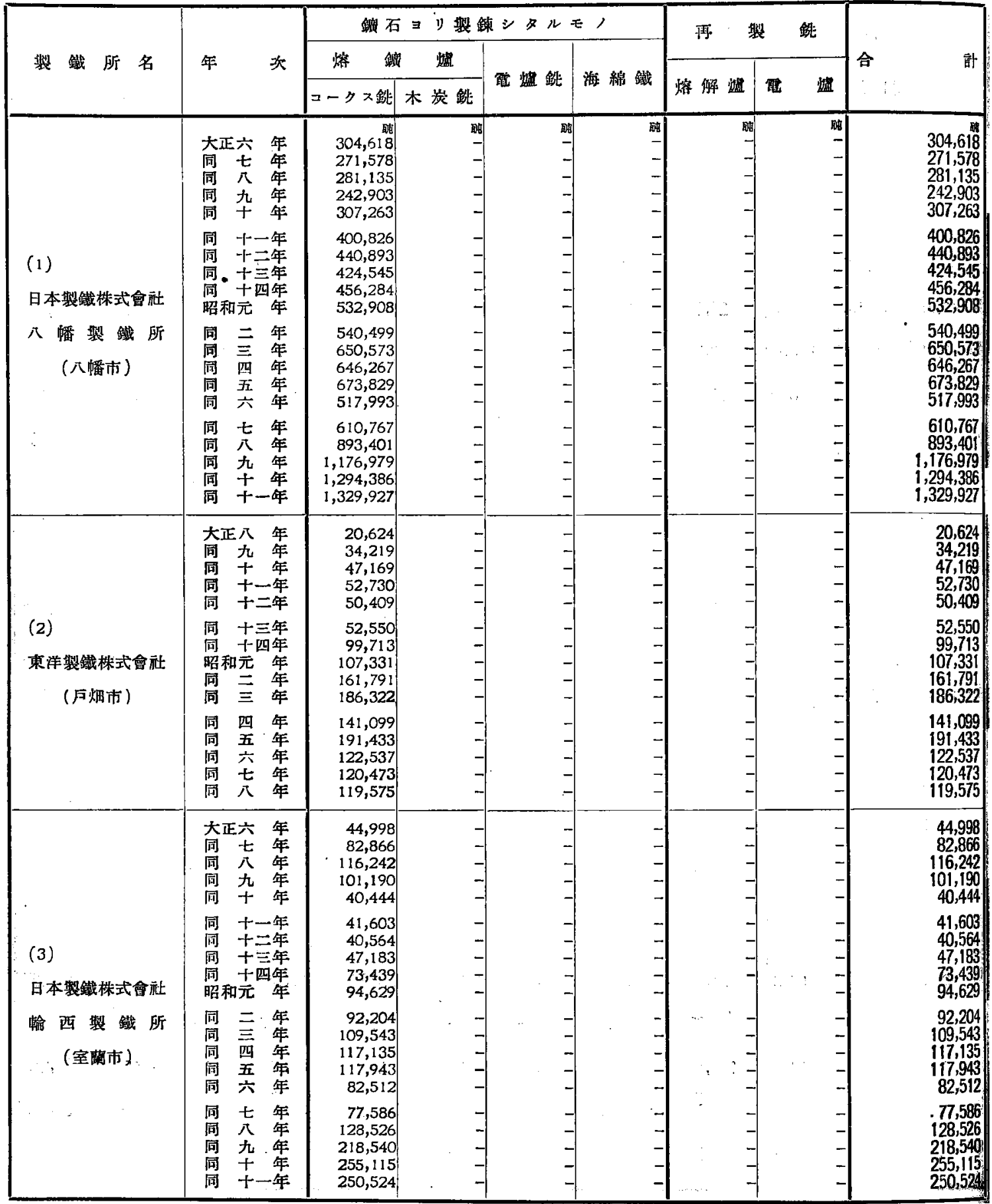

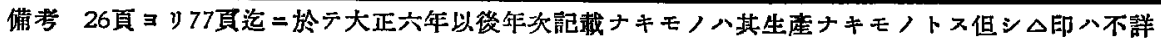

（1）昭和九年二月 元官營製鐵所ノ㱔鐵事業

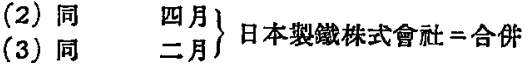


（其 二）

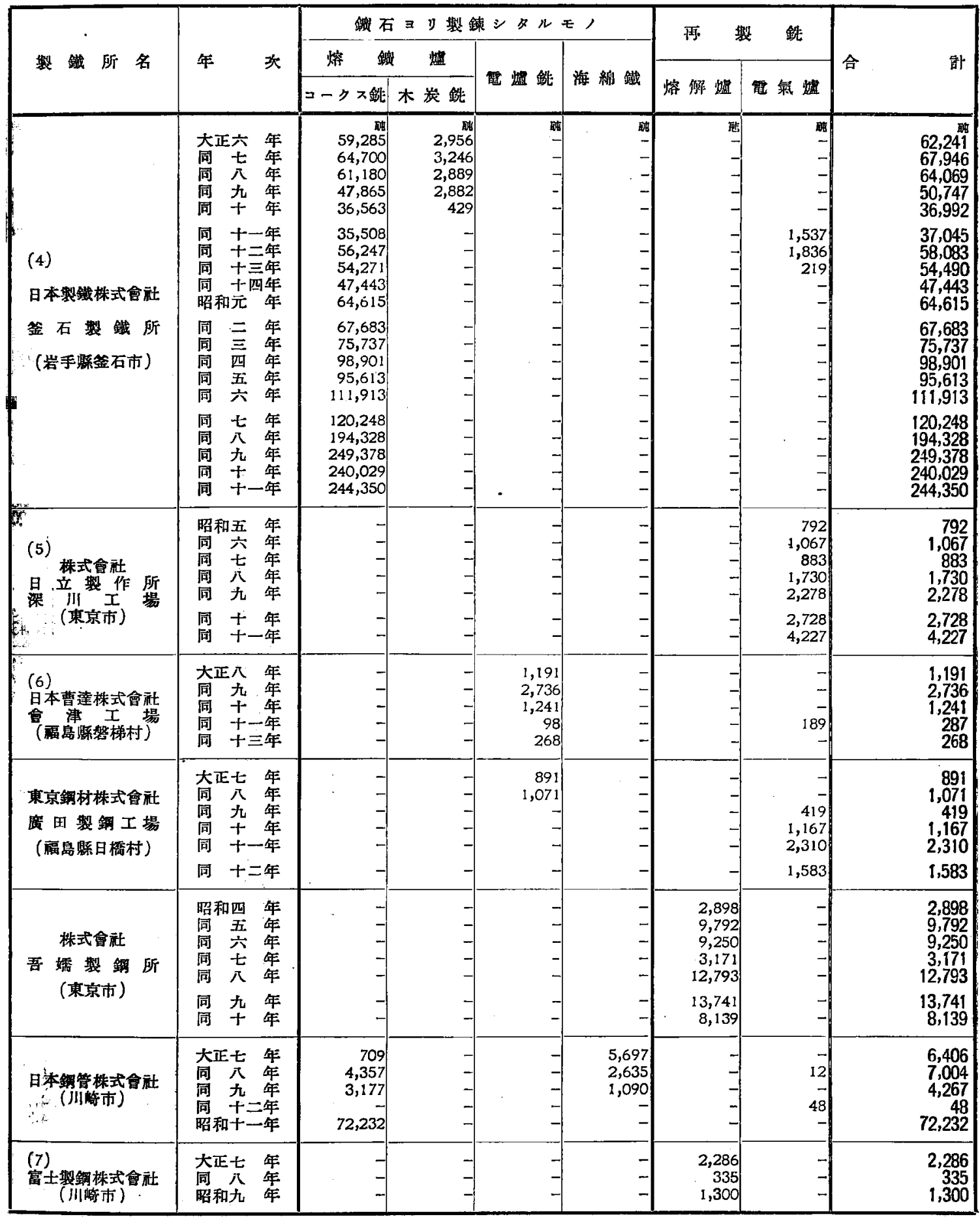

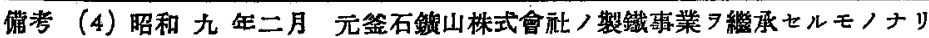

(5) 同 十二年五月 國應工業株式會社 7 合㴊七 1

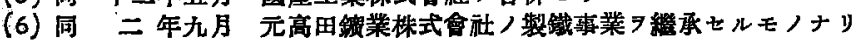


鉄鐵主要製鐵所別生產額調

（其

三)

\begin{tabular}{|c|c|c|c|c|c|c|c|c|}
\hline \multirow{3}{*}{ 裂 鐵 所 孚 } & \multirow{3}{*}{ 年 识 } & \multicolumn{4}{|c|}{ 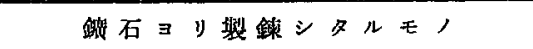 } & \multirow{2}{*}{\multicolumn{2}{|c|}{ 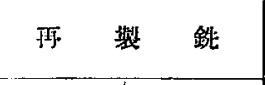 }} & \multirow{3}{*}{ 合 } \\
\hline & & \multirow{2}{*}{ 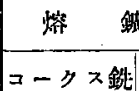 } & 显 & \multirow{2}{*}{ 娟烅錐 } & \multirow{2}{*}{ 海線䱛 } & & & \\
\hline & & & 木 岮 鮏 & & & 烙解鎾 & 踽 & \\
\hline 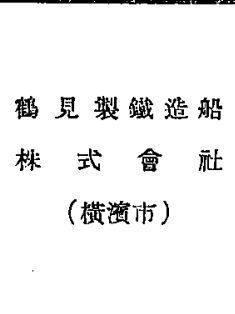 & 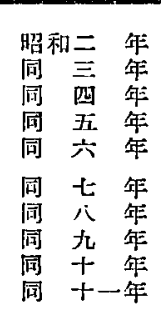 & \begin{tabular}{r|} 
阔 \\
22,164 \\
54,890 \\
62,506 \\
58,035 \\
61,490 \\
64,373 \\
67,672 \\
41,744 \\
75,043 \\
75,049
\end{tabular} & $\begin{array}{l}\text { 猎 } \\
- \\
- \\
- \\
- \\
- \\
- \\
- \\
-\end{array}$ & $\begin{array}{l}\text { 醋 } \\
- \\
- \\
- \\
- \\
- \\
- \\
-\end{array}$ & $\begin{array}{l}\text { 的 } \\
- \\
- \\
- \\
- \\
- \\
- \\
- \\
- \\
-\end{array}$ & $\begin{array}{l}\text { 暗 } \\
= \\
=\end{array}$ & $\begin{array}{l}\text { RE } \\
- \\
\overline{-} \\
- \\
- \\
- \\
- \\
- \\
- \\
-\end{array}$ & $\begin{array}{l}22,16 \\
54,890 \\
62,506 \\
58,039 \\
61,490 \\
64,373 \\
67,672 \\
41,744 \\
75,043 \\
75,049\end{array}$ \\
\hline 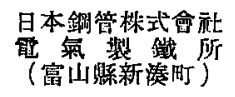 & $\begin{array}{l}\text { 大正九 垁 } \\
\text { 同十 年 } \\
\text { 同 }+ \text { 年 }\end{array}$ & $\begin{array}{l}- \\
-\end{array}$ & $=$ & $\begin{array}{r}1,644 \\
493 \\
-\end{array}$ & $\overline{-}$ & - & $\begin{array}{r}- \\
1,450 \\
255\end{array}$ & $\begin{array}{r}1,644 \\
1,943 \\
255\end{array}$ \\
\hline $\begin{array}{c}\text { 株式會社 } \\
\text { 日 立 製 作 所 } \\
\text { 木 捸 川 工 場 } \\
\text { (大阪市) }\end{array}$ & 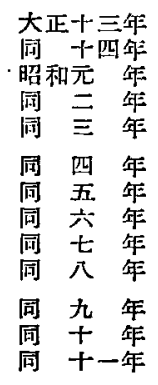 & $\begin{array}{l}- \\
- \\
- \\
- \\
- \\
- \\
- \\
- \\
- \\
- \\
- \\
- \\
-\end{array}$ & $\begin{array}{l}- \\
- \\
- \\
- \\
- \\
- \\
- \\
- \\
- \\
- \\
- \\
-\end{array}$ & $\begin{array}{l}- \\
- \\
- \\
- \\
- \\
-\end{array}$ & $\begin{array}{l}- \\
- \\
- \\
- \\
- \\
- \\
- \\
- \\
- \\
- \\
-\end{array}$ & $\begin{array}{l}- \\
- \\
- \\
-\end{array}$ & $\begin{array}{r}1,835 \\
3,228 \\
3,162 \\
4,063 \\
6,795 \\
8,550 \\
8,420 \\
6,419 \\
7,203 \\
9,852 \\
10,564 \\
11,496 \\
11,543\end{array}$ & \begin{tabular}{r|}
1,835 \\
3,25 \\
3,162 \\
4,063 \\
6,795 \\
8,550 \\
8,420 \\
6,419 \\
7,203 \\
9,852 \\
10,56 \\
11,49 \\
11,54
\end{tabular} \\
\hline 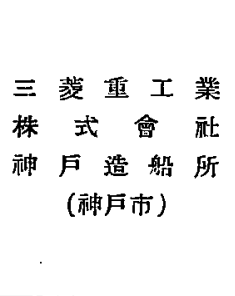 & 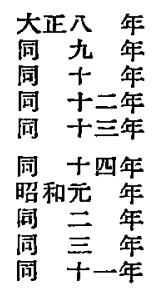 & $\begin{array}{l}- \\
- \\
- \\
- \\
- \\
- \\
- \\
-\end{array}$ & $\begin{array}{l}- \\
- \\
- \\
- \\
- \\
- \\
- \\
-\end{array}$ & $\begin{array}{l}- \\
- \\
- \\
- \\
- \\
- \\
- \\
-\end{array}$ & $\begin{array}{l}- \\
- \\
- \\
- \\
- \\
- \\
- \\
-\end{array}$ & $\begin{array}{r}154 \\
27 \\
195 \\
226 \\
163 \\
153 \\
245 \\
95 \\
18 \\
49\end{array}$ & $\begin{array}{l}- \\
- \\
- \\
- \\
- \\
- \\
- \\
- \\
-\end{array}$ & $\begin{array}{r}15 \\
79 \\
9 \\
26 \\
163 \\
153 \\
245 \\
95 \\
18 \\
49\end{array}$ \\
\hline $\begin{array}{l}\text { 株式會社 } \\
\text { 日 立亦 作 所 } \\
\text { F 畑 工 場 } \\
\text { (F烟市) }\end{array}$ & 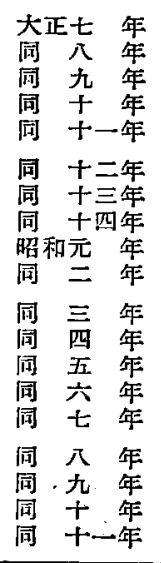 & $\begin{array}{l}- \\
- \\
- \\
- \\
- \\
- \\
- \\
- \\
- \\
- \\
- \\
- \\
- \\
- \\
- \\
-\end{array}$ & $\begin{array}{l}- \\
- \\
- \\
- \\
- \\
- \\
- \\
- \\
- \\
- \\
- \\
- \\
- \\
- \\
- \\
-\end{array}$ & $\begin{array}{l}- \\
- \\
- \\
- \\
- \\
- \\
- \\
- \\
- \\
- \\
- \\
- \\
- \\
- \\
-\end{array}$ & $\begin{array}{l}- \\
- \\
- \\
- \\
- \\
- \\
- \\
- \\
- \\
- \\
- \\
- \\
- \\
- \\
- \\
- \\
- \\
-\end{array}$ & $\begin{array}{r}5,783 \\
5,857 \\
3,383 \\
1,735 \\
2,300 \\
1,746 \\
1,194 \\
553 \\
- \\
- \\
- \\
- \\
- \\
- \\
- \\
-\end{array}$ & $\begin{array}{r}- \\
- \\
- \\
- \\
1,091 \\
2,943 \\
2,973 \\
3,686 \\
6,236 \\
6,574 \\
7,168 \\
7,481 \\
5,673 \\
4,148 \\
4,580 \\
8,300 \\
10,526 \\
12,139 \\
11,021\end{array}$ & 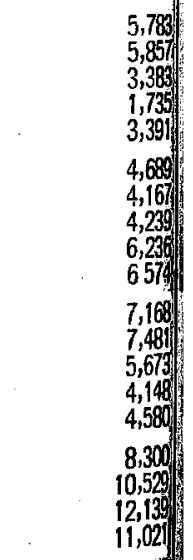 \\
\hline
\end{tabular}


（其

四)

\begin{tabular}{|c|c|c|c|c|c|c|c|c|}
\hline \multirow{3}{*}{ 製 䥫 所 名 } & \multirow{3}{*}{ 年 } & \multicolumn{4}{|c|}{ 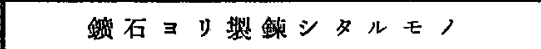 } & \multirow{2}{*}{\multicolumn{2}{|c|}{ 雨. }} & \multirow{3}{*}{ 合 } \\
\hline & & 寉 & 蠉 & \multirow{2}{*}{ 電燸跳 } & \multirow{2}{*}{ 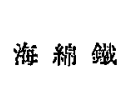 } & & & \\
\hline & & $=-ク \times$ 錐 & 炭 䤵 & & & 熔解焙 & 霞 & \\
\hline 其他 製 鐵 所 & 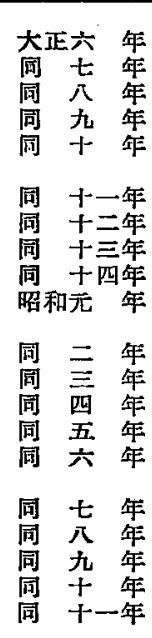 & $\begin{array}{r}r \\
2,800 \\
18,360 \\
8,917 \\
- \\
- \\
- \\
- \\
- \\
- \\
- \\
- \\
- \\
- \\
- \\
- \\
- \\
-\end{array}$ & $\begin{array}{r}r 8 \\
2,388 \\
9,488 \\
\epsilon, 010 \\
6,997 \\
8,027 \\
3,076 \\
- \\
153 \\
7 \\
381 \\
2,000 \\
241 \\
- \\
1,253 \\
3, \\
5,363 \\
6,039\end{array}$ & $\begin{array}{r}- \\
- \\
- \\
- \\
122 \\
320 \\
720 \\
835\end{array}$ & $\begin{array}{r}\text { 接 } \\
- \\
- \\
- \\
- \\
- \\
- \\
- \\
- \\
- \\
925 \\
853 \\
82 \\
57 \\
- \\
102 \\
162 \\
207 \\
154 \\
139\end{array}$ & $\begin{array}{r}5 \text { 湖 } \\
5,355 \\
12,550 \\
6,040 \\
3,012 \\
5,865 \\
3,394 \\
3,167 \\
528 \\
437 \\
- \\
-\end{array}$ & $\begin{array}{r}\text { 明 } \\
- \\
- \\
- \\
36 \\
52 \\
- \\
- \\
89 \\
498 \\
173 \\
256 \\
209 \\
66 \\
13 \\
- \\
42 \\
110 \\
872 \\
2,471\end{array}$ & $\begin{array}{r}7,743 \\
2,738 \\
24,8310 \\
18,426 \\
13,928 \\
6,522 \\
3,167 \\
528 \\
679 \\
498 \\
1,098 \\
1,490 \\
2,291 \\
364 \\
13 \\
1,477 \\
505 \\
4,405 \\
7,712 \\
8,649\end{array}$ \\
\hline 合 (丙 地) & 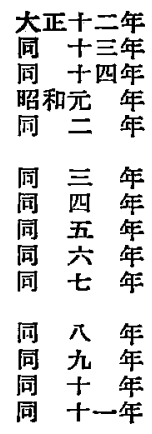 & $\begin{array}{r}588,113 \\
578,549 \\
676,879 \\
799,483 \\
884,341 \\
1,077,065 \\
1,065,908 \\
1,136,853 \\
896,445 \\
693,447 \\
\\
1,403,502 \\
1,686,641 \\
1,864,573 \\
1,972,082\end{array}$ & $\begin{array}{r}- \\
270 \\
153 \\
- \\
- \\
381 \\
2,000 \\
241 \\
- \\
1,253 \\
3 \\
3,368 \\
5,851 \\
6,039\end{array}$ & $\begin{array}{r}268 \\
- \\
- \\
- \\
- \\
- \\
122 \\
301 \\
720 \\
835 \\
-\end{array}$ & $\begin{array}{r}- \\
- \\
- \\
925 \\
853 \\
82 \\
57 \\
- \\
102 \\
162 \\
207 \\
154 \\
139\end{array}$ & $\begin{array}{r}5,139 \\
1,885 \\
1,143 \\
245 \\
95 \\
18 \\
2,898 \\
9,792 \\
9,250 \\
3,171 \\
12,793 \\
13,741 \\
8,139 \\
49\end{array}$ & $\begin{array}{r}6,446 \\
5,079 \\
7,003 \\
9,896 \\
10,810 \\
14,219 \\
16,240 \\
14,951 \\
11,647 \\
12,666 \\
19,924 \\
23,481 \\
27,235 \\
29,262\end{array}$ & $\begin{array}{r}599,698 \\
586,051 \\
685,178 \\
809,624 \\
896,171 \\
1,092,536 \\
1,087,128 \\
1,161,894 \\
917,342 \\
1,010,761 \\
1,436,682 \\
1,728,158 \\
1,906,787 \\
2,007,571\end{array}$ \\
\hline 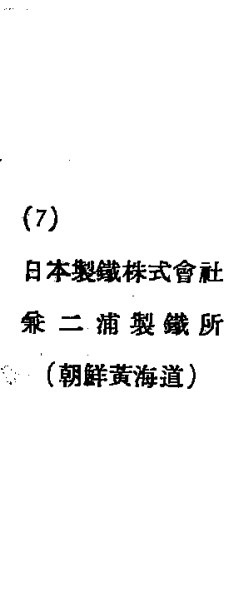 & 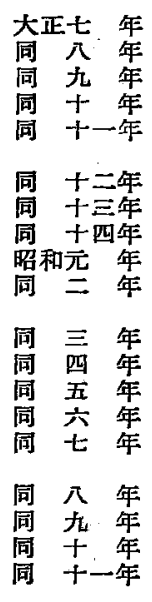 & $\begin{array}{r}42,698 \\
78,384 \\
84,118 \\
83,010 \\
83,179 \\
99,933 \\
99,795 \\
99,160 \\
115,036 \\
129,022 \\
146,159 \\
153,627 \\
150,524 \\
147,257 \\
161,940 \\
161,163 \\
210,807 \\
21,441 \\
216,751\end{array}$ & $\begin{array}{l}- \\
- \\
- \\
-\end{array}$ & $\begin{array}{l}- \\
- \\
- \\
-\end{array}$ & $\begin{array}{l}- \\
- \\
- \\
- \\
-\end{array}$ & $\begin{array}{l}- \\
- \\
- \\
-\end{array}$ & $\begin{array}{l} \\
+ \\
+\end{array}$ & $\begin{array}{r}42,698 \\
78,384 \\
84,118 \\
83,010 \\
83,179 \\
99,933 \\
99,735 \\
99,160 \\
115,036 \\
129,022 \\
146,159 \\
153,627 \\
150,524 \\
147,257 \\
161,940 \\
161,163 \\
210,1607 \\
211,441 \\
216,751\end{array}$ \\
\hline
\end{tabular}




\section{銑鐵主要製鐵所別生產調}

(其

五)

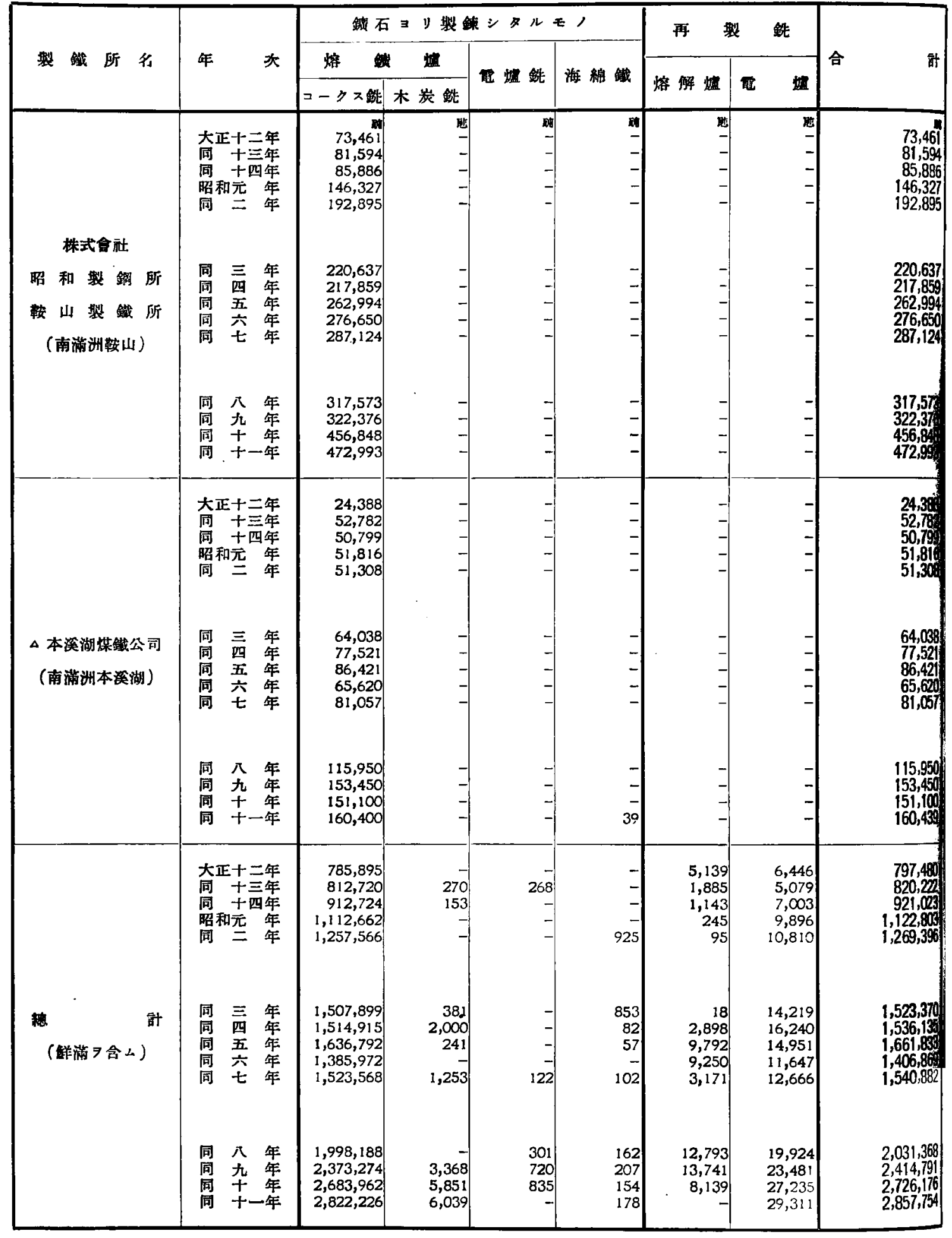


フエロアロイ主要製鐵所別生產額調

(其 $\quad-$ )

\begin{tabular}{|c|c|c|c|c|c|c|c|c|c|c|}
\hline 製 驖 所名 & 次 & $\begin{array}{l}\text { フェロ } \\
\text { マンガ } \\
\text { ン }\end{array}$ & 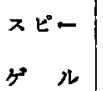 & $\begin{array}{l}7 \pm 0 \\
\sum^{2} y= \\
8\end{array}$ & 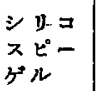 & $\begin{array}{l}\text { フェロ } \\
\text { クロム }\end{array}$ & $\begin{array}{l}7 \pm 0 \\
\text { タะク } \\
\text { ステン }\end{array}$ & $\begin{array}{l}\text { フェロ } \\
\text { モリフ } \\
\text { デン }\end{array}$ & 其 他 & 合 \\
\hline 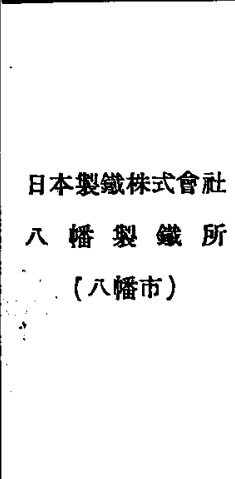 & 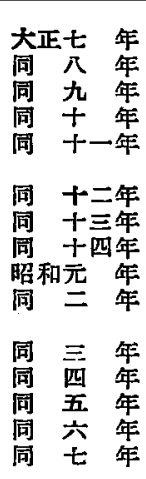 & $\begin{array}{r}\text { ng } \\
30 \\
110 \\
231 \\
784 \\
168 \\
1,042 \\
1,308 \\
1 \\
8 \\
60 \\
7 \\
369 \\
539 \\
15\end{array}$ & $\begin{array}{l}\text { at } \\
- \\
- \\
- \\
- \\
- \\
- \\
- \\
- \\
- \\
- \\
- \\
- \\
-\end{array}$ & \begin{tabular}{r|}
$r 5$ \\
39 \\
22 \\
43 \\
73 \\
253 \\
95 \\
39 \\
512 \\
602 \\
351 \\
49 \\
494 \\
282 \\
393 \\
323
\end{tabular} & $\begin{array}{l}\text { 明 } \\
- \\
- \\
- \\
-\end{array}$ & $\begin{array}{r}\text { 1月 } \\
14 \\
3 \\
4 \\
6 \\
3\end{array}$ & \begin{tabular}{r|}
98 \\
98 \\
28 \\
22 \\
-1
\end{tabular} & $\begin{array}{r}\text { 潳 } \\
- \\
-\end{array}$ & $\begin{array}{r}\text { an } \\
9 \\
9 \\
- \\
- \\
- \\
- \\
- \\
- \\
54 \\
- \\
- \\
-\end{array}$ & $\begin{array}{r}186 \\
172 \\
300 \\
863 \\
424 \\
1,140 \\
1,407 \\
518 \\
625 \\
419 \\
121 \\
633 \\
822 \\
393 \\
338\end{array}$ \\
\hline 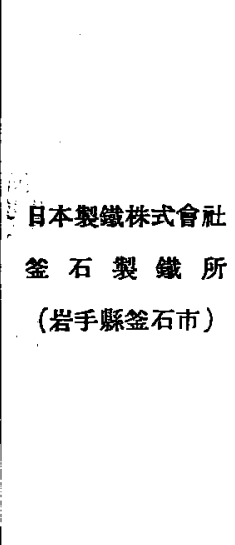 & 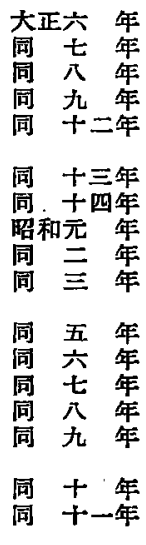 & $\begin{array}{r}5,121 \\
5,650 \\
4,066 \\
1,141 \\
264 \\
533 \\
477 \\
157 \\
464 \\
141 \\
482 \\
918 \\
1,348 \\
1,531 \\
2,803 \\
2,923 \\
6,156\end{array}$ & $\begin{array}{r}1,473 \\
1,005 \\
166 \\
446 \\
- \\
- \\
- \\
- \\
- \\
- \\
- \\
- \\
- \\
- \\
- \\
-\end{array}$ & $\begin{array}{r}- \\
- \\
- \\
15 \\
180 \\
179 \\
242 \\
307 \\
107 \\
49 \\
190 \\
116 \\
- \\
- \\
- \\
-\end{array}$ & $\begin{array}{l}- \\
- \\
-\end{array}$ & $\begin{array}{r}- \\
56 \\
- \\
- \\
- \\
- \\
- \\
-\end{array}$ & $\begin{array}{l}- \\
- \\
-\end{array}$ & - & $\begin{array}{l}- \\
- \\
- \\
- \\
- \\
- \\
- \\
- \\
- \\
- \\
- \\
- \\
- \\
-\end{array}$ & $\begin{array}{r}6,594 \\
6,655 \\
4,232 \\
1,587 \\
279 \\
713 \\
656 \\
455 \\
771 \\
248 \\
531 \\
1,108 \\
1,464 \\
1,531 \\
2,803 \\
2,923 \\
6,156\end{array}$ \\
\hline 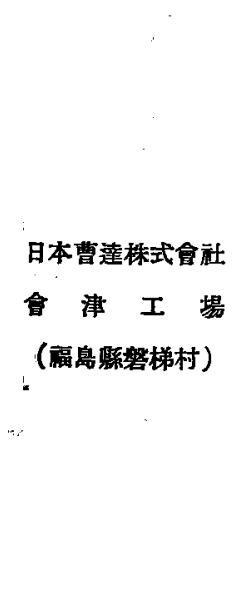 & 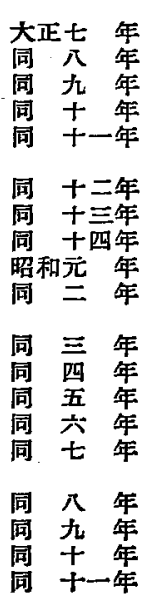 & $\begin{array}{r}- \\
- \\
317 \\
340 \\
1,326 \\
1,472 \\
492 \\
845 \\
1,300 \\
902 \\
1,364 \\
817 \\
342 \\
1,114 \\
958 \\
471 \\
695 \\
169\end{array}$ & $\begin{array}{r}261 \\
951 \\
145 \\
- \\
3 \\
233 \\
197 \\
- \\
- \\
- \\
97 \\
104 \\
- \\
- \\
55 \\
22 \\
91\end{array}$ & $\begin{array}{r}545 \\
428 \\
41 \\
370 \\
242 \\
147 \\
76 \\
378 \\
367 \\
147\end{array}$ & 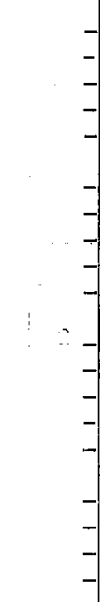 & $\begin{array}{r}- \\
21 \\
51 \\
- \\
-\end{array}$ & $\begin{array}{l}- \\
- \\
-\end{array}$ & $\begin{array}{l}- \\
- \\
-\end{array}$ & $\begin{array}{r}32 \\
- \\
- \\
- \\
31 \\
- \\
- \\
- \\
- \\
77 \\
357 \\
534 \\
101 \\
38 \\
-1\end{array}$ & $\begin{array}{r}545 \\
742 \\
1,043 \\
832 \\
582 \\
1,476 \\
1,812 \\
1,067 \\
1,212 \\
1,447 \\
1,074 \\
1,820 \\
1,096 \\
768 \\
1,682 \\
1,332 \\
1,137 \\
1,679 \\
1,173\end{array}$ \\
\hline
\end{tabular}

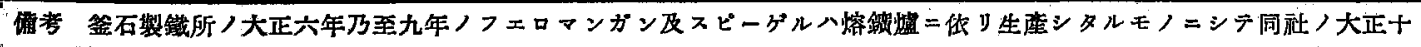

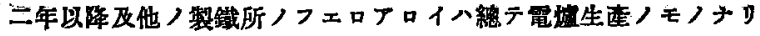




\section{フエロアロイ主要製鐵所別生產額調}

（其而）

\begin{tabular}{|c|c|c|c|c|c|c|c|c|c|c|}
\hline 㳖 钱 所 名 & 年次 & $\begin{array}{l}\text { フェロ } \\
\text { マンガ } \\
\text { ン }\end{array}$ & $\begin{array}{l}\text { スピー } \\
\text { ゲル }\end{array}$ & 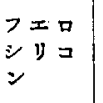 & $\begin{array}{l}シ y= \\
\pi ヒ ゚ ー \\
\text { ゲル }\end{array}$ & $\begin{array}{l}\text { フェロ } \\
\text { クロム }\end{array}$ & $\begin{array}{l}\text { フェロ } \\
\text { タング } \\
\text { ステン }\end{array}$ & 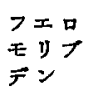 & 其 & 合. \\
\hline $\begin{array}{c}\text { 株式會社 } \\
\text { 鐵 舆 隔山形工場 } \\
\text { (山形古) }\end{array}$ & $\begin{array}{lll}\text { 照和五 } & \text { 年 } \\
\text { 同 } & \text { 六 } & \text { 年 } \\
\text { 同 } & \text { 年 } \\
\text { 同 } & \text { 年 } \\
\text { 间 九 } & \text { 年 } \\
\text { 同 } & \text { ト一年 }\end{array}$ & \begin{tabular}{r|}
. \\
1,084 \\
1,293 \\
1,823 \\
1,615 \\
1,020
\end{tabular} & - & \begin{tabular}{r|} 
蜎 \\
836 \\
- \\
622 \\
410 \\
558
\end{tabular} & $\begin{array}{l}\text { 蚟 } \\
- \\
- \\
- \\
-\end{array}$ & $\begin{array}{r}\text { 明 } \\
- \\
37 \\
63 \\
94 \\
-\end{array}$ & $\begin{array}{l}\text { at } \\
- \\
- \\
- \\
-\end{array}$ & $\begin{array}{l}\text { 础 } \\
- \\
- \\
- \\
-\end{array}$ & $\begin{array}{r}96 \\
96 \\
- \\
102 \\
- \\
- \\
676\end{array}$ & $\begin{array}{r}932 \\
1,084 \\
2,054 \\
2,296 \\
2,267 \\
1,696\end{array}$ \\
\hline 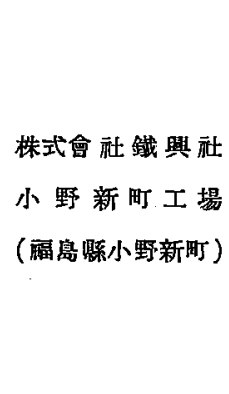 & 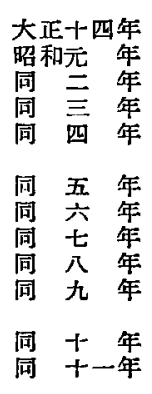 & $\begin{array}{r}22 \\
663 \\
1,320 \\
1,246 \\
1,937 \\
1,758 \\
- \\
- \\
- \\
8 \\
366\end{array}$ & $\begin{array}{r}155 \\
170 \\
73 \\
143 \\
163 \\
- \\
- \\
- \\
-\end{array}$ & $\begin{array}{r}432 \\
645 \\
856 \\
954 \\
1,582 \\
820 \\
982 \\
1,330 \\
1,561 \\
1,514 \\
1,914 \\
1,560\end{array}$ & $\begin{array}{r}- \\
- \\
46 \\
53 \\
68\end{array}$ & $\begin{array}{l}- \\
- \\
- \\
- \\
- \\
- \\
- \\
- \\
- \\
-\end{array}$ & $\begin{array}{l}- \\
- \\
- \\
- \\
- \\
- \\
- \\
-\end{array}$ & - & $\begin{array}{r}- \\
- \\
20 \\
24 \\
- \\
- \\
- \\
- \\
- \\
- \\
-\end{array}$ & $\begin{array}{r}609 \\
1,478 \\
2,315 \\
2,410 \\
3,779 \\
2,578 \\
982 \\
1,330 \\
1,56 \\
1,52 \\
2,280 \\
1,560\end{array}$ \\
\hline 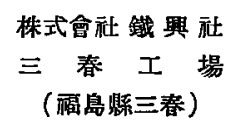 & $\begin{array}{lll}\text { 昭和四 } & \text { 年 } \\
\text { 同 } & \text { 望 } & \text { 年 } \\
\text { 同 } & \text { 六 } & \text { 年 } \\
\text { 同 } & \text { 年 }\end{array}$ & & - & $\begin{array}{l}- \\
- \\
-\end{array}$ & $\begin{array}{l}- \\
- \\
-\end{array}$ & $\begin{array}{l}- \\
- \\
-\end{array}$ & $\begin{array}{l}- \\
- \\
-\end{array}$ & & $\begin{array}{r}96 \\
318 \\
259 \\
136\end{array}$ & $\begin{array}{r}96 \\
318 \\
259 \\
136\end{array}$ \\
\hline 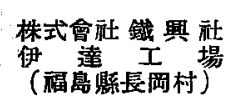 & $\begin{array}{ll}\text { 昭和八 } & \text { 年 } \\
\text { 同九 } & \text { 年 } \\
\text { 同 十 } & \text { 年 }\end{array}$ & - & - & $\begin{array}{l}753 \\
656 \\
327\end{array}$ & $=$ & $\overline{-}$ & - & & $\begin{array}{l}- \\
-\end{array}$ & $\begin{array}{l}753 \\
656 \\
327\end{array}$ \\
\hline 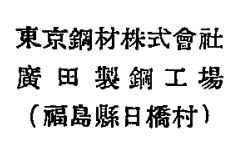 & 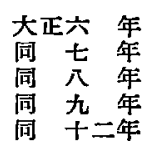 & $\begin{array}{r}550 \\
898 \\
227 \\
-\end{array}$ & $\begin{array}{r}11 \\
53 \\
- \\
8 \\
-7\end{array}$ & $\begin{array}{r}800 \\
955 \\
344 \\
2 \\
29\end{array}$ & $\begin{array}{r}307 \\
692 \\
- \\
34 \\
-\end{array}$ & $\begin{array}{r}184 \\
234 \\
- \\
-\end{array}$ & $\begin{array}{r}138 \\
26 \\
- \\
- \\
-\end{array}$ & - & $\begin{array}{l}- \\
- \\
- \\
-\end{array}$ & $\begin{array}{r}1,990 \\
2,850 \\
57 \\
4 \\
29\end{array}$ \\
\hline $\begin{array}{c}\text { 三菱䥊業株式會社 } \\
\text { 大 阪 裴 煉 所 } \\
\text { (大阪市) }\end{array}$ & $\begin{array}{l}\text { 昭和四 } \\
\text { 年 } \\
\text { 同 吾 } \\
\text { 年 } \\
\text { 亲 } \\
\text { 年 } \\
\text { 同 } \\
\text { 年 } \\
\text { 年 }\end{array}$ & $\begin{array}{l}- \\
- \\
- \\
-\end{array}$ & - & $\begin{array}{l}- \\
- \\
- \\
-\end{array}$ & $\begin{array}{l}- \\
- \\
- \\
-\end{array}$ & $\begin{array}{l}- \\
- \\
- \\
-\end{array}$ & $\begin{array}{r}30 \\
26 \\
13 \\
40 \\
326\end{array}$ & & $\begin{array}{l}- \\
- \\
- \\
- \\
-\end{array}$ & \begin{tabular}{r|}
30 \\
25 \\
13 \\
40 \\
326
\end{tabular} \\
\hline 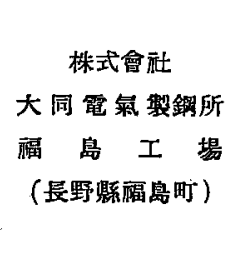 & $\begin{array}{l}\text { 大正九 年 } \\
\text { 同 } \\
\text { 间年 } \\
\text { 昭和七年 } \\
\text { 问 } \\
\text { 年 } \\
\text { 同 } 九 \text { 年 } \\
\text { 同十 年 } \\
\text { 同 十一年 }\end{array}$ & $\begin{array}{r}1,072 \\
358 \\
- \\
- \\
- \\
- \\
-\end{array}$ & 270 & $\begin{array}{l}392 \\
237 \\
413 \\
157 \\
3: 3\end{array}$ & $\begin{array}{l}- \\
- \\
- \\
-\end{array}$ & $\begin{array}{r}649 \\
1,070 \\
100 \\
- \\
- \\
- \\
-\end{array}$ & $\begin{array}{l}- \\
- \\
-\end{array}$ & - & $\begin{array}{l}- \\
- \\
- \\
-\end{array}$ & 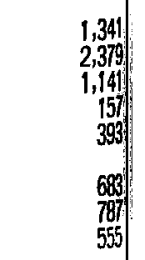 \\
\hline 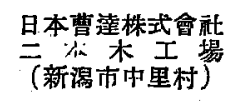 & $\begin{array}{lll}\text { 昭和四 } & \text { 年 } \\
\text { 同 } & \text { 五 } \\
\text { 同 年 } \\
\text { 六 }\end{array}$ & $\begin{array}{r}1,236 \\
756 \\
407\end{array}$ & - & $\begin{array}{r}121 \\
13\end{array}$ & - &. & - & - & $=$ & $\begin{array}{r}1,235 \\
877 \\
420\end{array}$ \\
\hline
\end{tabular}


（其 三）

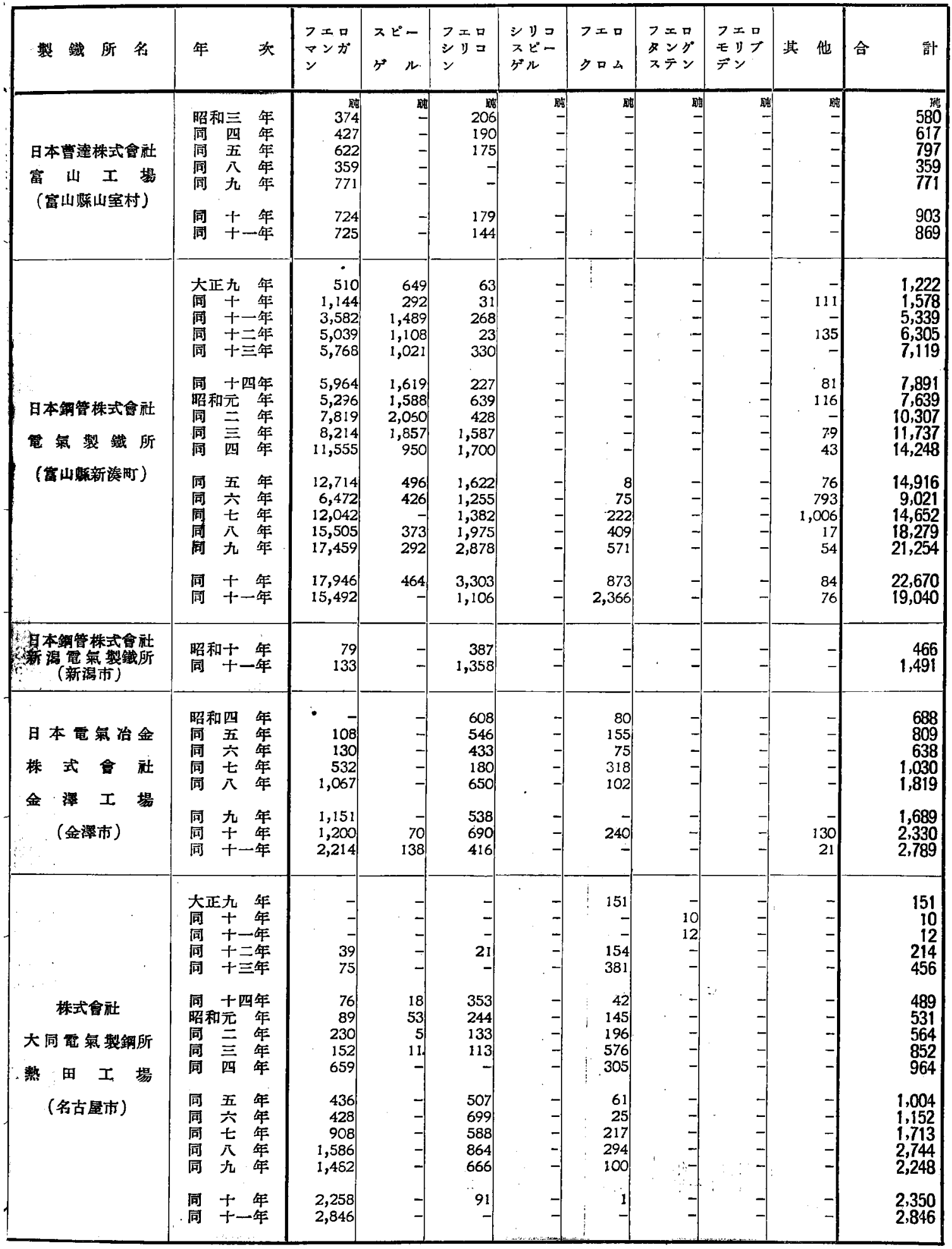




\section{フエロアロイ主要製鐵所別生產額調}

(其 四)

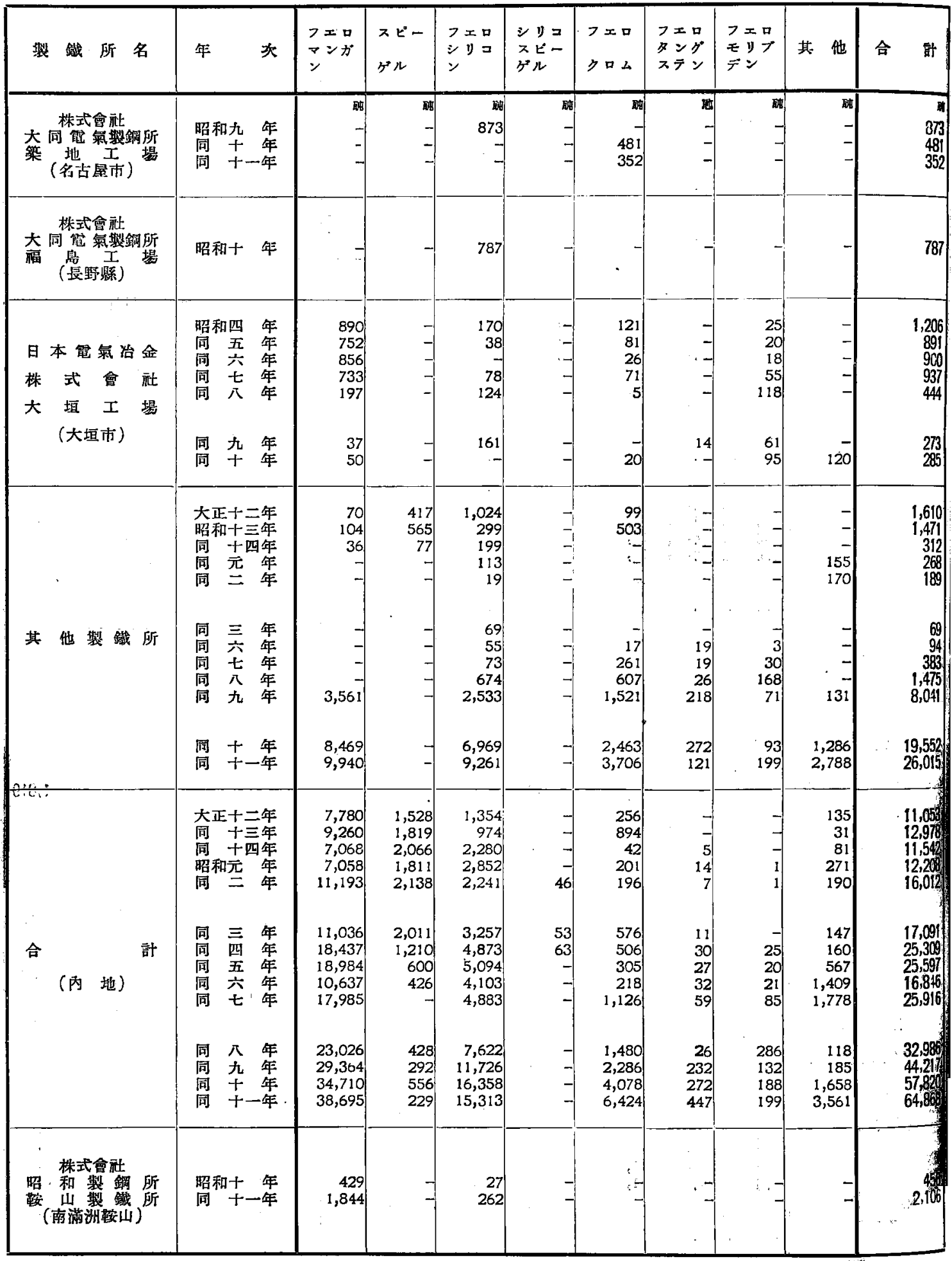




\section{鋼主要製鐵所別生產額調}

(其 -

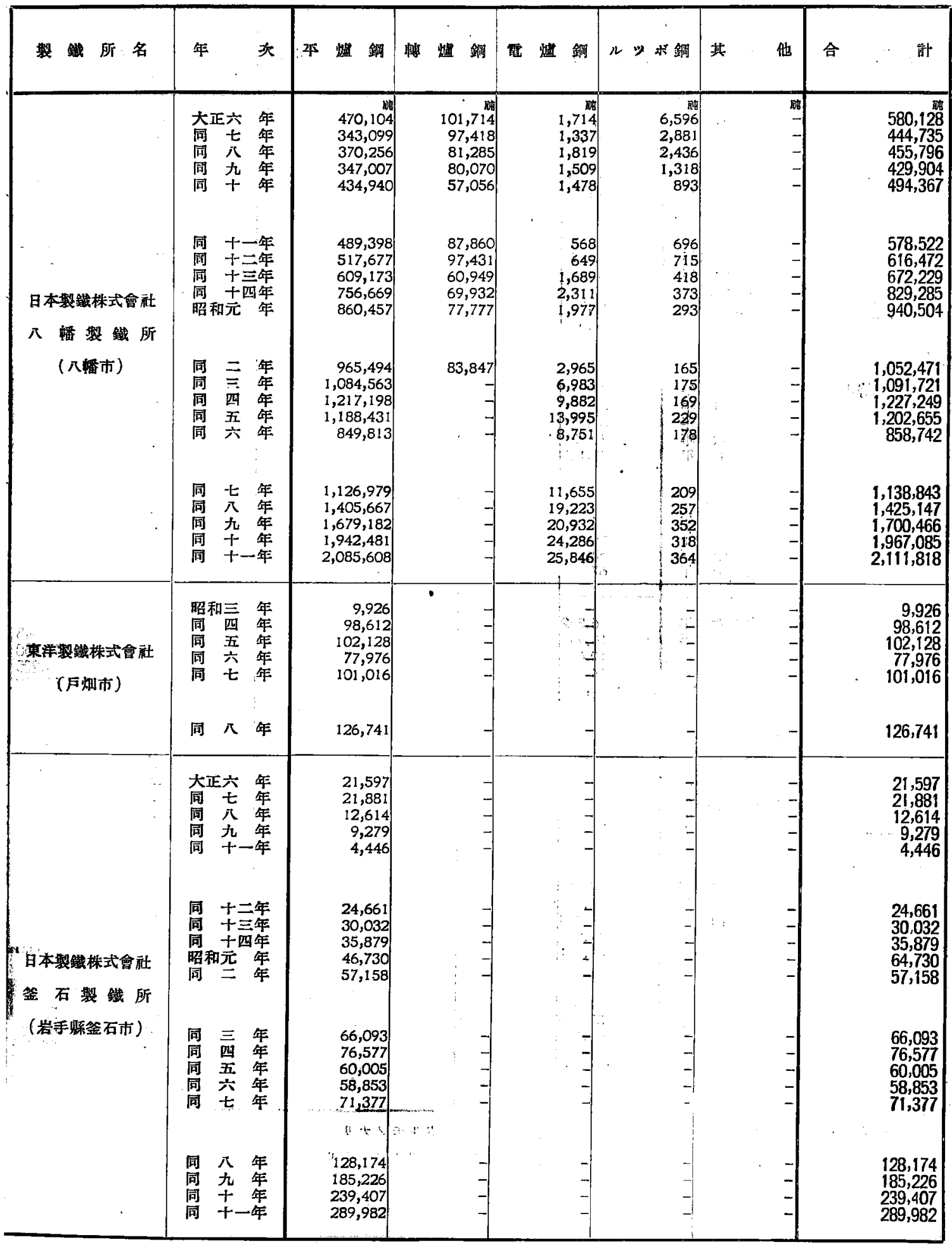




\section{鎆主要製鐵所別生產額調}

(其 二)

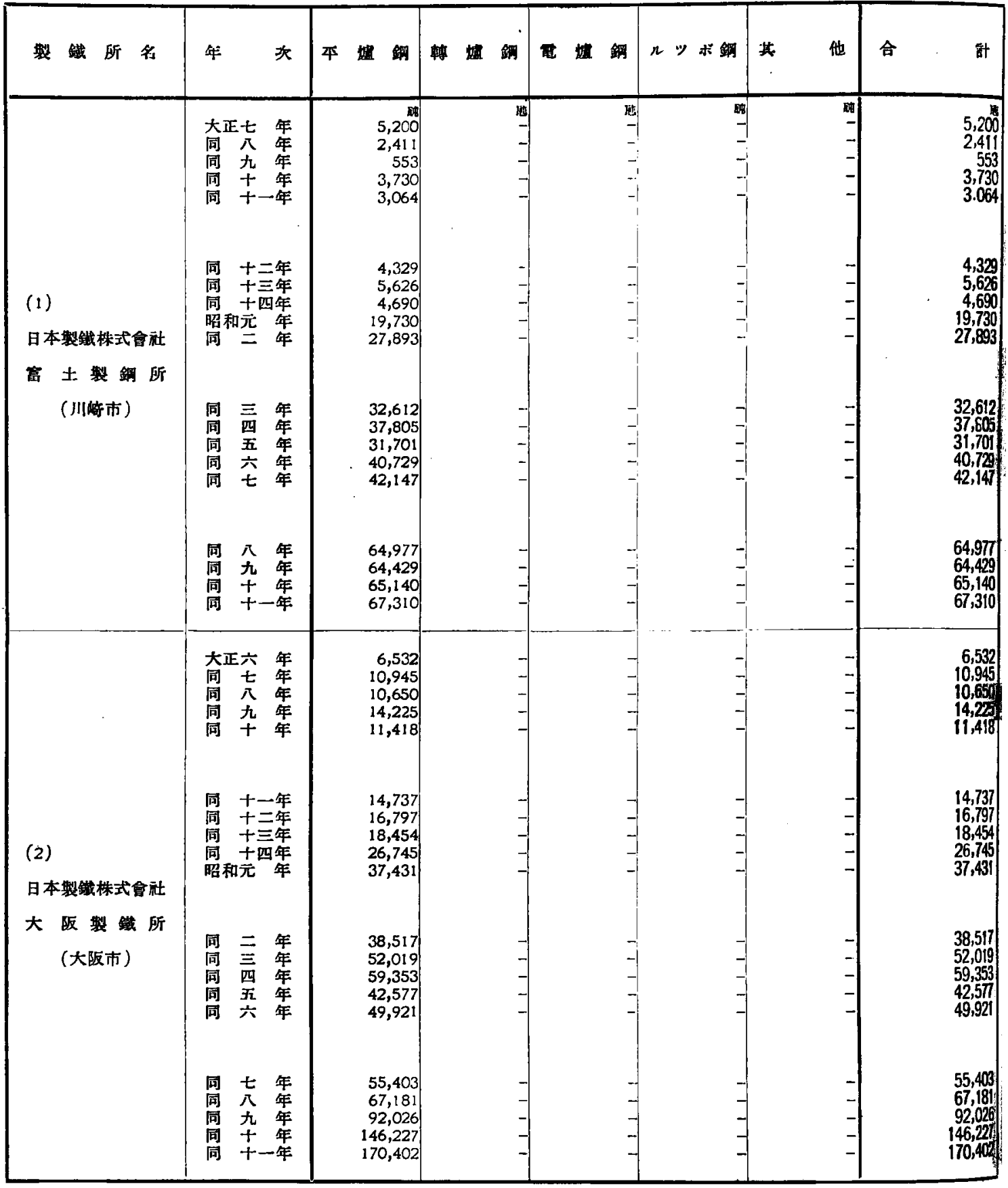

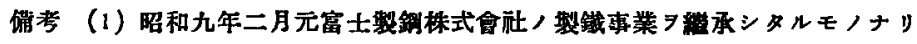

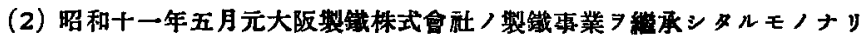


（其 三）

\begin{tabular}{|c|c|c|c|c|c|c|c|}
\hline 製 鐵 所 名 & 次 & 平 蛙 鈴 & 轉 螘 鋼 & 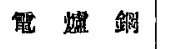 & ルッ ボ鲫 & 其 & 殷 \\
\hline 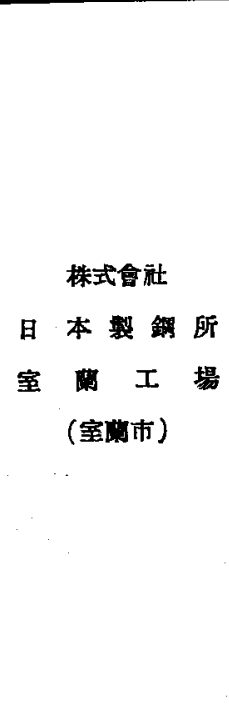 & 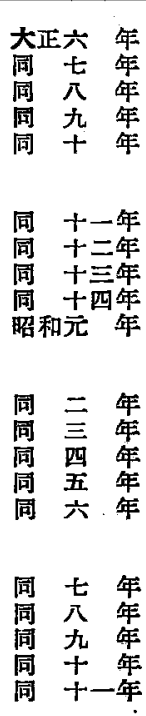 & $\begin{array}{l}72,454 \\
82,341 \\
60,255 \\
69,572 \\
47,130 \\
\\
22,835 \\
19,579 \\
29,127 \\
36,535 \\
39,481 \\
\\
27,015 \\
31,828 \\
36,495 \\
26,049 \\
12,904 \\
\\
34,951 \\
76,940 \\
77,107 \\
76,927 \\
64,581\end{array}$ & $\begin{array}{l}\text { 酎 } \\
- \\
- \\
- \\
- \\
- \\
- \\
-\end{array}$ & 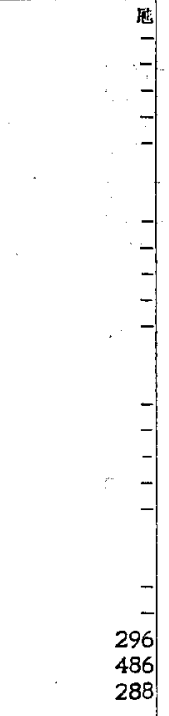 & $\begin{array}{r}\text { 明 } \\
- \\
7 \\
79 \\
7 \\
30 \\
57 \\
84 \\
24 \\
\\
75 \\
25 \\
29 \\
32 \\
26 \\
\\
12 \\
36 \\
7 \\
- \\
-\end{array}$ & $\begin{array}{l}\text { 盟 } \\
- \\
- \\
- \\
- \\
- \\
- \\
- \\
- \\
- \\
- \\
- \\
-\end{array}$ & $\begin{array}{l}72,454 \\
82,341 \\
60,255 \\
69,572 \\
47,209 \\
\\
22,842 \\
19,609 \\
29,184 \\
36,619 \\
39,505 \\
\\
27,090 \\
31,853 \\
36,554 \\
26,081 \\
12,930 \\
\\
34,963 \\
76,940 \\
77,403 \\
77,413 \\
61,869\end{array}$ \\
\hline 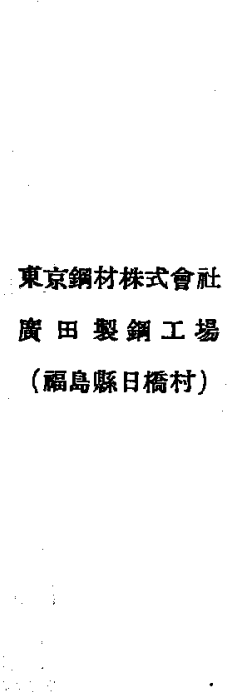 & 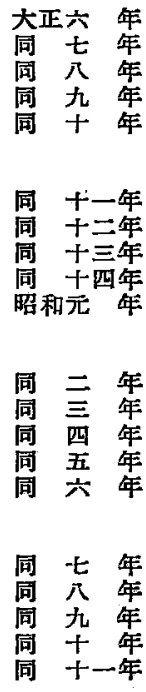 & $\begin{array}{l}- \\
\overline{-} \\
- \\
-\end{array}$ & $\begin{array}{l}- \\
y \\
-\end{array}$ & $\begin{array}{r}20 \\
14 \\
283 \\
5 \\
775 \\
\\
793 \\
1.400 \\
1,200 \\
2,261 \\
3,463 \\
\\
3,895 \\
4,690 \\
4,885 \\
3,992 \\
3,121 \\
\\
5,169 \\
10,317 \\
11,976 \\
12,943 \\
14.705\end{array}$ & $\begin{array}{l}- \\
- \\
- \\
-1\end{array}$ & $\begin{array}{l}\therefore \\
\cdots\end{array}$ & $\begin{array}{r}20 \\
14 \\
283 \\
5 \\
775 \\
\\
793 \\
793 \\
1,400 \\
1,200 \\
2,261 \\
3,483 \\
\\
3,895 \\
4,690 \\
4,885 \\
3,992 \\
3,121 \\
\\
5,169 \\
10,317 \\
11,976 \\
12,943 \\
14,705\end{array}$ \\
\hline $\begin{array}{l}\text { (3) } \\
\text { 日 立製作 所 } \\
\text { 川 工 暘 } \\
\text { (東京市) }\end{array}$ & $\begin{array}{lll}\text { 昭和五 } & \text { 年 } \\
\text { 同 } & \text { 年 } \\
\text { 同 } & \text { 年 } \\
\text { 同 } & \text { 年 } \\
\text { 同 } & \text { 年 }\end{array}$ & $\begin{array}{l}- \\
-\end{array}$ & $\begin{array}{l}- \\
- \\
- \\
-\end{array}$ & $\begin{array}{r}438 \\
949 \\
1,909 \\
2,726 \\
2,275 \\
\\
\\
\\
2,640 \\
5,377\end{array}$ & $\begin{array}{l}- \\
- \\
- \\
-\end{array}$ & $\begin{array}{l}- \\
- \\
- \\
-\end{array}$ & $\begin{array}{r}438 \\
949 \\
1,909 \\
2,726 \\
2,275 \\
\\
\\
\\
2,640 \\
5,377\end{array}$ \\
\hline
\end{tabular}

（3）昭和十二年五月國兴工業株式會社 7 合併七 y 


\section{鋼主要製鐵所別生產額調}

（其四）

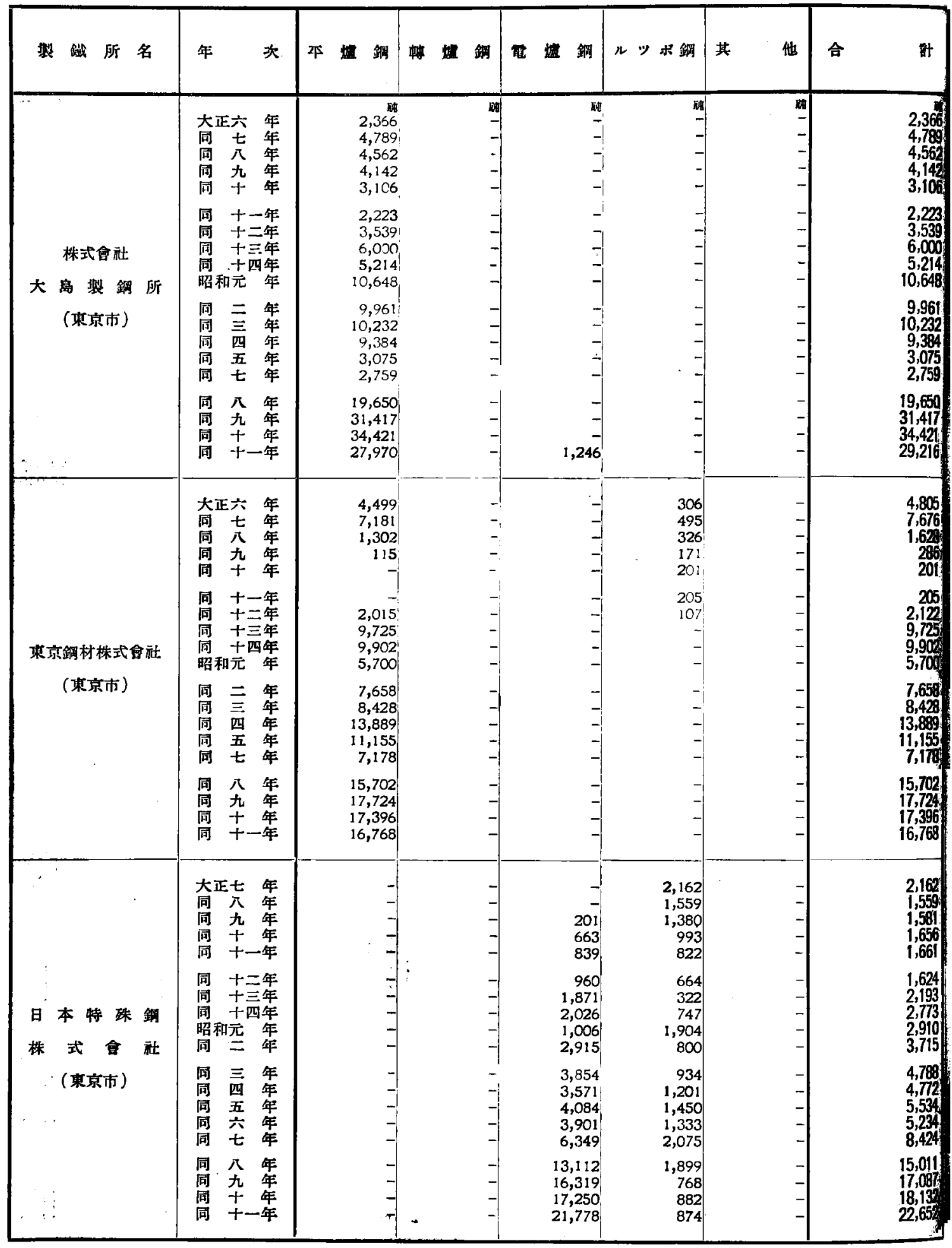


（其 五）

\begin{tabular}{|c|c|c|c|c|c|c|c|}
\hline 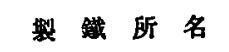 & 次 & 平 蝹 鋼 & 咹蝹銅 & 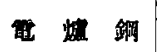 & ルッボ銀 & 其 & 合 \\
\hline $\begin{array}{c}\text { 日本鋂龬株式會社 } \\
\text { (東京市) }\end{array}$ & 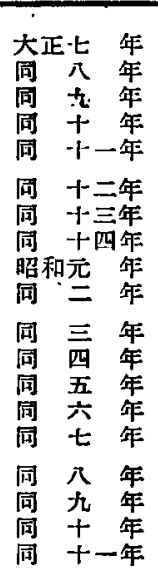 & $\begin{array}{l}n t \\
- \\
- \\
- \\
-\end{array}$ & $\begin{array}{r}5,3 \\
5,34 \\
4,14 \\
3,30 \\
3,13 \\
2,37 \\
2,34 \\
2,47 \\
2,54 \\
3,03 \\
1,77 \\
1,15 \\
7 \\
7 \\
7 \\
7\end{array}$ & $\begin{array}{r}r \\
- \\
- \\
- \\
- \\
- \\
- \\
- \\
325 \\
532 \\
1,402 \\
1,512 \\
1,670 \\
2,301 \\
3,072 \\
3,983 \\
4,174 \\
4,084\end{array}$ & 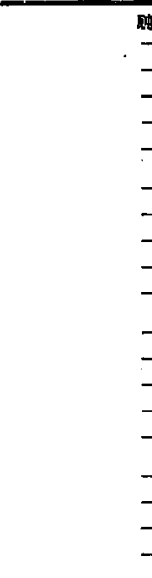 & $\begin{array}{l}\text { 明 } \\
- \\
- \\
- \\
- \\
- \\
- \\
- \\
- \\
- \\
- \\
- \\
- \\
- \\
- \\
- \\
- \\
- \\
-\end{array}$ & $\begin{array}{l}5,346 \\
4,448 \\
3,308 \\
3,132 \\
2,371 \\
2,342 \\
2,479 \\
2,541 \\
3,030 \\
2,100 \\
1,686 \\
1,472 \\
1,512 \\
1,670 \\
2,301 \\
3,072 \\
3,983 \\
4,174 \\
4,084\end{array}$ \\
\hline 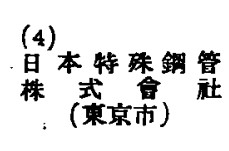 & 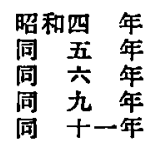 & $\begin{array}{l}-1 \\
-1 \\
-1 \\
-1 \\
-1\end{array}$ & 3 & $\begin{array}{r}200 \\
170 \\
300 \\
18,187 \\
31,534\end{array}$ & 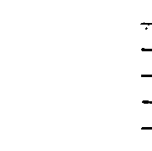 & $\begin{array}{l}- \\
- \\
- \\
-\end{array}$ & $\begin{array}{r}200 \\
200 \\
300 \\
18,187 \\
31,534\end{array}$ \\
\hline $\begin{array}{c}\text { 株式合社 } \\
\text { 吾 耣 銅 所 } \\
\text { (来京市) }\end{array}$ & 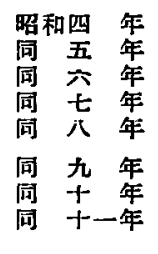 & $\begin{array}{r}- \\
1,400 \\
16,795 \\
32,808 \\
40,201 \\
41,742 \\
80,894 \\
79,355\end{array}$ & & $\begin{array}{r}459 \\
7,770 \\
5,968 \\
2,481 \\
- \\
565 \\
- \\
-\end{array}$ & 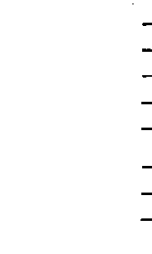 & $\begin{array}{l}- \\
- \\
- \\
- \\
- \\
- \\
-\end{array}$ & $\begin{array}{r}459 \\
9,170 \\
22,763 \\
35,289 \\
40,201 \\
42,307 \\
80,894 \\
79,355\end{array}$ \\
\hline 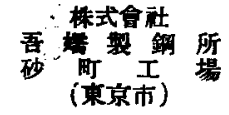 & $\begin{array}{l}\text { 昭和九 年 } \\
\text { 同 十年 } \\
\text { 同 十一年 }\end{array}$ & $\begin{array}{l}10,145 \\
27,460 \\
32,642\end{array}$ & & $=$ & 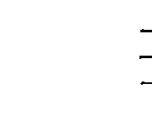 & $\begin{array}{l}- \\
-\end{array}$ & $\begin{array}{l}10,145 \\
27,460 \\
32,642\end{array}$ \\
\hline 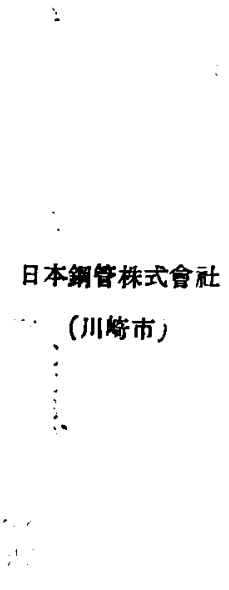 & 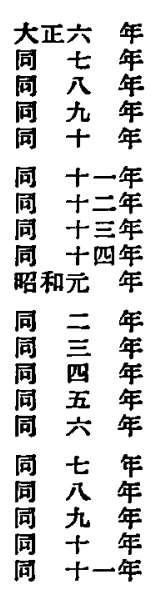 & $\begin{array}{r}49,065 \\
69,689 \\
58,185 \\
73,279 \\
63,304 \\
97,649 \\
87,396 \\
118,651 \\
132,414 \\
136,352 \\
161,127 \\
203,572 \\
223,577 \\
193,728 \\
179,378 \\
225,477 \\
286,089 \\
353,603 \\
470,225 \\
526,732\end{array}$ & 要 & $\begin{array}{r}- \\
- \\
- \\
- \\
- \\
- \\
- \\
- \\
- \\
- \\
2,923 \\
2,217 \\
2,084 \\
-\end{array}$ & 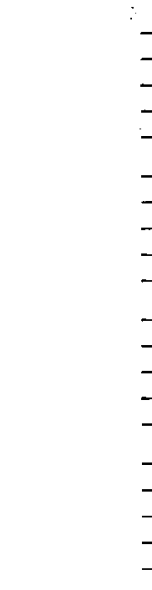 & $\begin{array}{l}- \\
- \\
- \\
- \\
- \\
- \\
- \\
- \\
- \\
- \\
- \\
- \\
- \\
- \\
- \\
- \\
- \\
- \\
-\end{array}$ & $\begin{array}{r}49,065 \\
69,689 \\
58,185 \\
73,279 \\
63,304 \\
97,649 \\
87,396 \\
118,651 \\
123,414 \\
136,352 \\
161,127 \\
203,572 \\
226,500 \\
195,945 \\
181,462 \\
225,477 \\
286,089 \\
353,603 \\
470,225 \\
526,732\end{array}$ \\
\hline
\end{tabular}




\section{鋼主要製鐵所別生產額調}

（其 六)

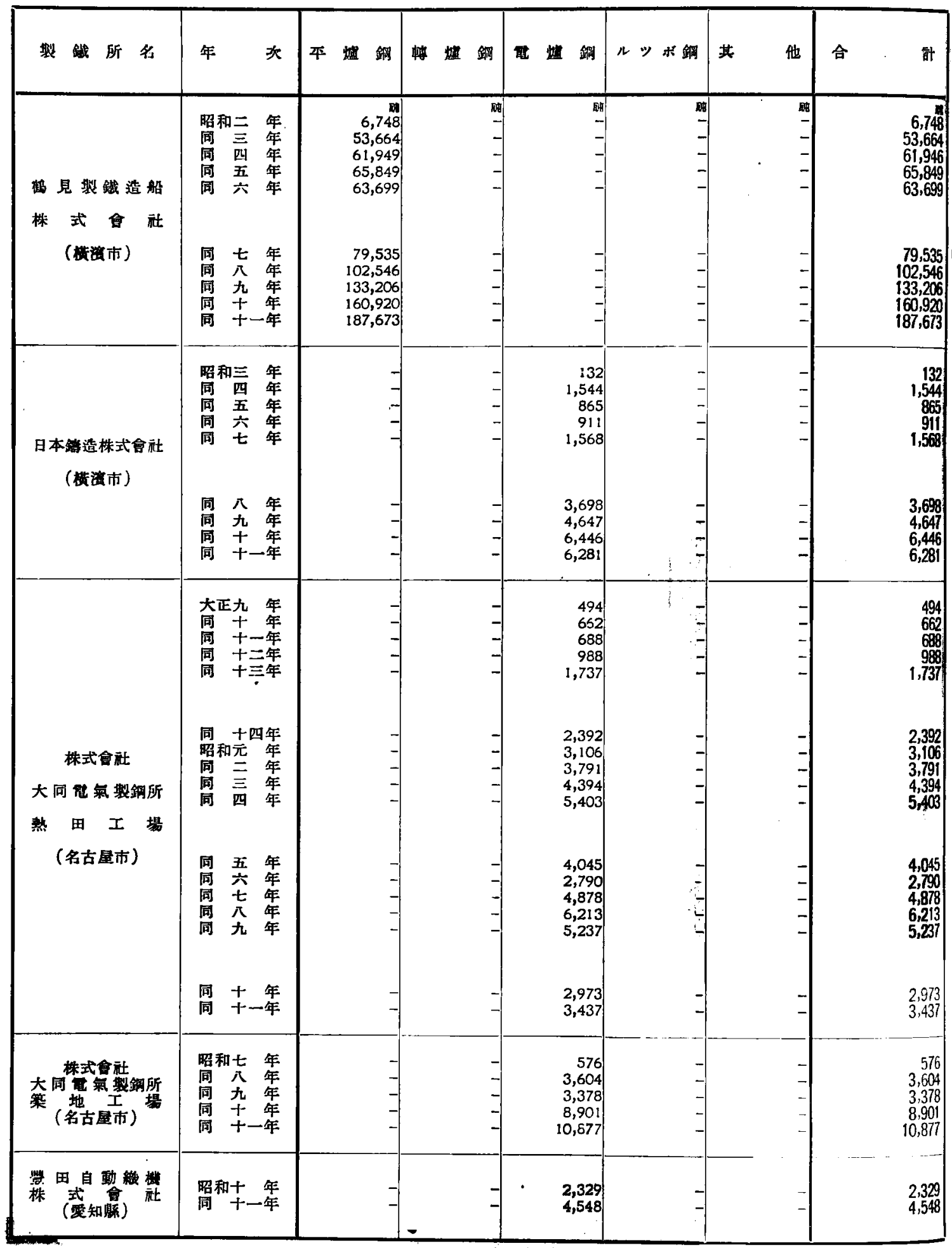


（其

t)

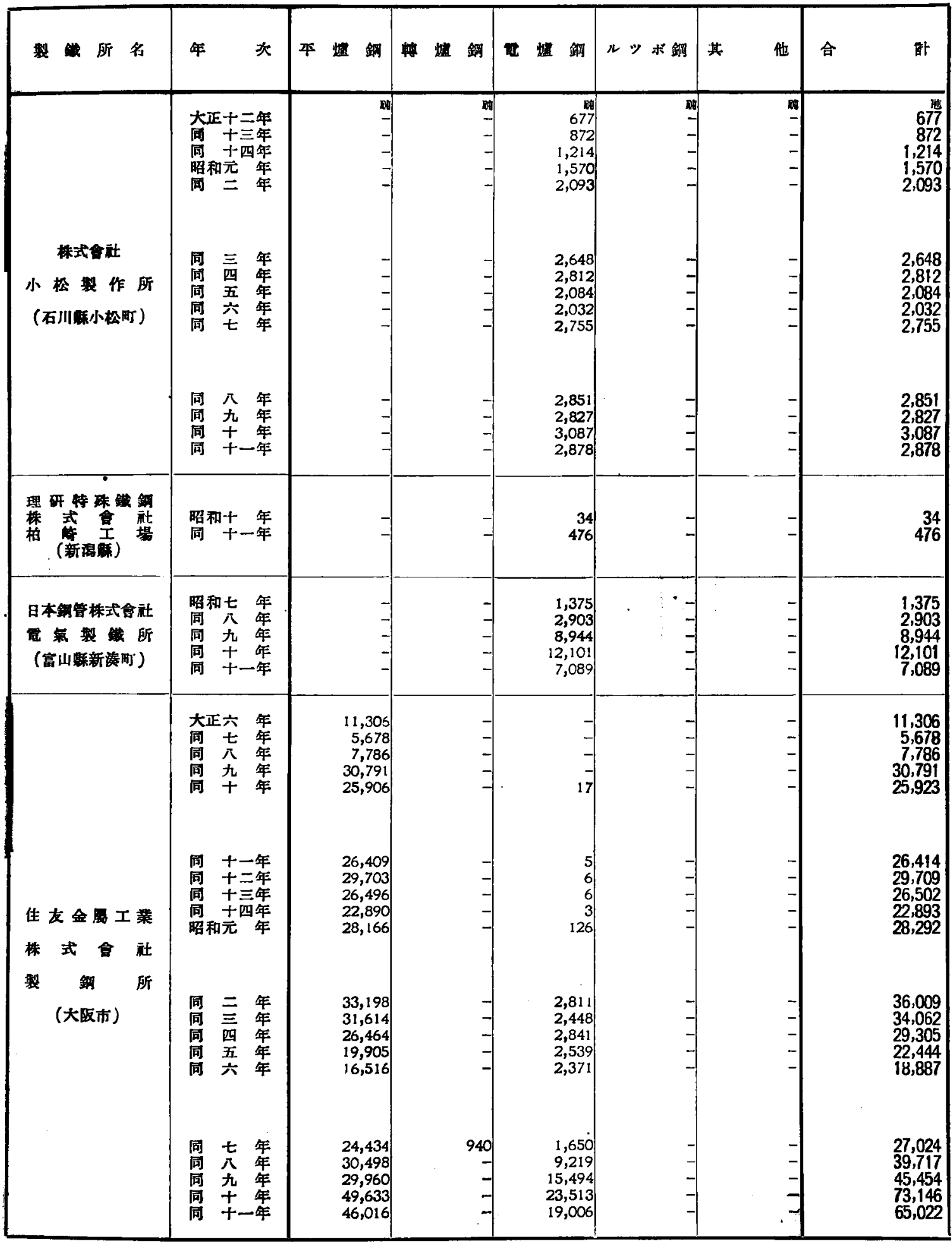




\section{鋼主要製鐵所別生產額調}

(其

八)

\begin{tabular}{|c|c|c|c|c|c|c|c|c|}
\hline 慗践所名 & 作 & 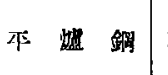 & 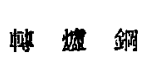 & 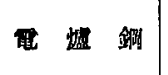 & ルッ米铜 & 共 & 合 & 解 \\
\hline 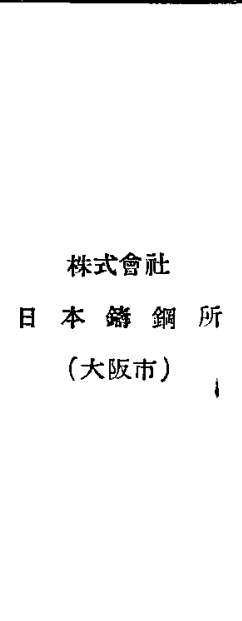 & 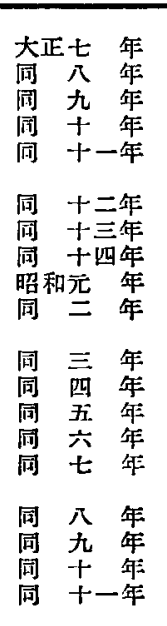 & - & $\begin{array}{l}4,508 \\
3,1153 \\
3,991 \\
2,599 \\
1,456 \\
3,024 \\
2,655 \\
1,326 \\
1,47\end{array}$ & 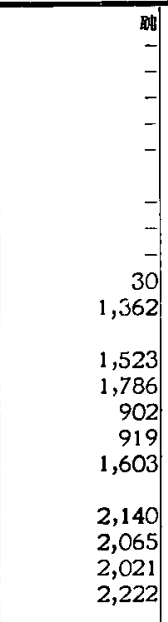 & $\begin{array}{l}- \\
- \\
-\end{array}$ & 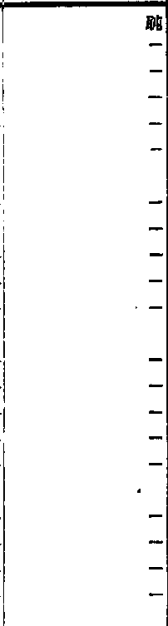 & $\therefore$ & 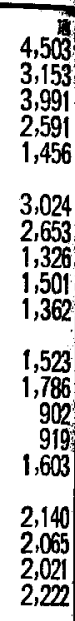 \\
\hline 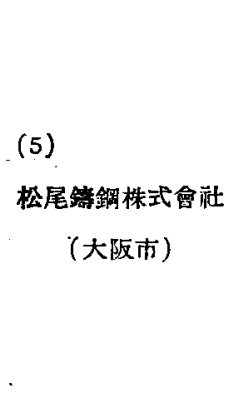 & 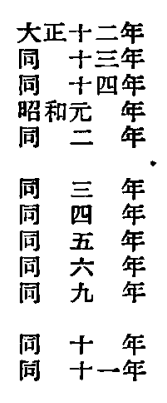 & $\begin{array}{r}1,158 \\
86 \\
543 \\
1,206 \\
748 \\
1,557 \\
963 \\
58 \\
1,58 \\
1,500 \\
2,033 \\
1,132\end{array}$ & & & & & $\because$ & $\begin{array}{r}1,158 \\
866 \\
543 \\
1,206 \\
748 \\
1,557 \\
998 \\
5989 \\
1,58 \\
1,500 \\
2,033 \\
1,132\end{array}$ \\
\hline 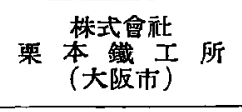 & $\begin{array}{l}\text { 盟和九 年 } \\
\text { 年 }\end{array}$ & & & $\begin{array}{l}1,251 \\
1,933\end{array}$ & - & & & $\begin{array}{l}1,25 ! \\
i, 933\end{array}$ \\
\hline 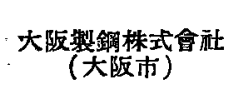 & $\begin{array}{l}\text { 腮和九 年 } \\
\text { 筒 } \\
+十 一 \text { 年 }\end{array}$ & $\begin{array}{r}8,263 \\
57,140 \\
74,392\end{array}$ & & $=$ & - & & & $\begin{array}{l}\frac{8,239}{57.40} \\
74,392\end{array}$ \\
\hline 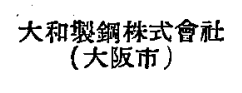 & $\begin{array}{l}\text { 㬏和 }+ \text { - 年 } \\
\text { 年 }\end{array}$ & $\begin{array}{l}43,500 \\
65,858\end{array}$ & & & & & & $\begin{array}{l}43,500 \\
65,558\end{array}$ \\
\hline 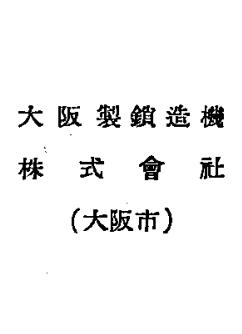 & 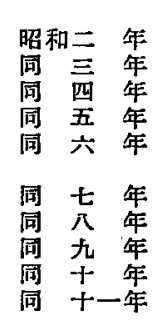 & 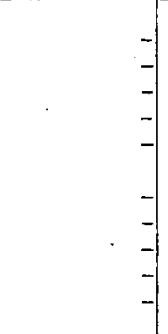 & & $\begin{array}{r}222 \\
222 \\
434 \\
316 \\
311 \\
629 \\
746 \\
1,463 \\
1,981 \\
2,278\end{array}$ & & & & $\begin{array}{r}222 \\
222 \\
434 \\
336 \\
311 \\
629 \\
746 \\
1,468 \\
1,968 \\
2,218\end{array}$ \\
\hline
\end{tabular}

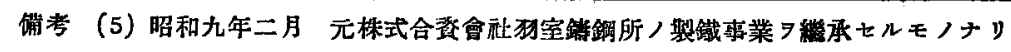


(筫

九)

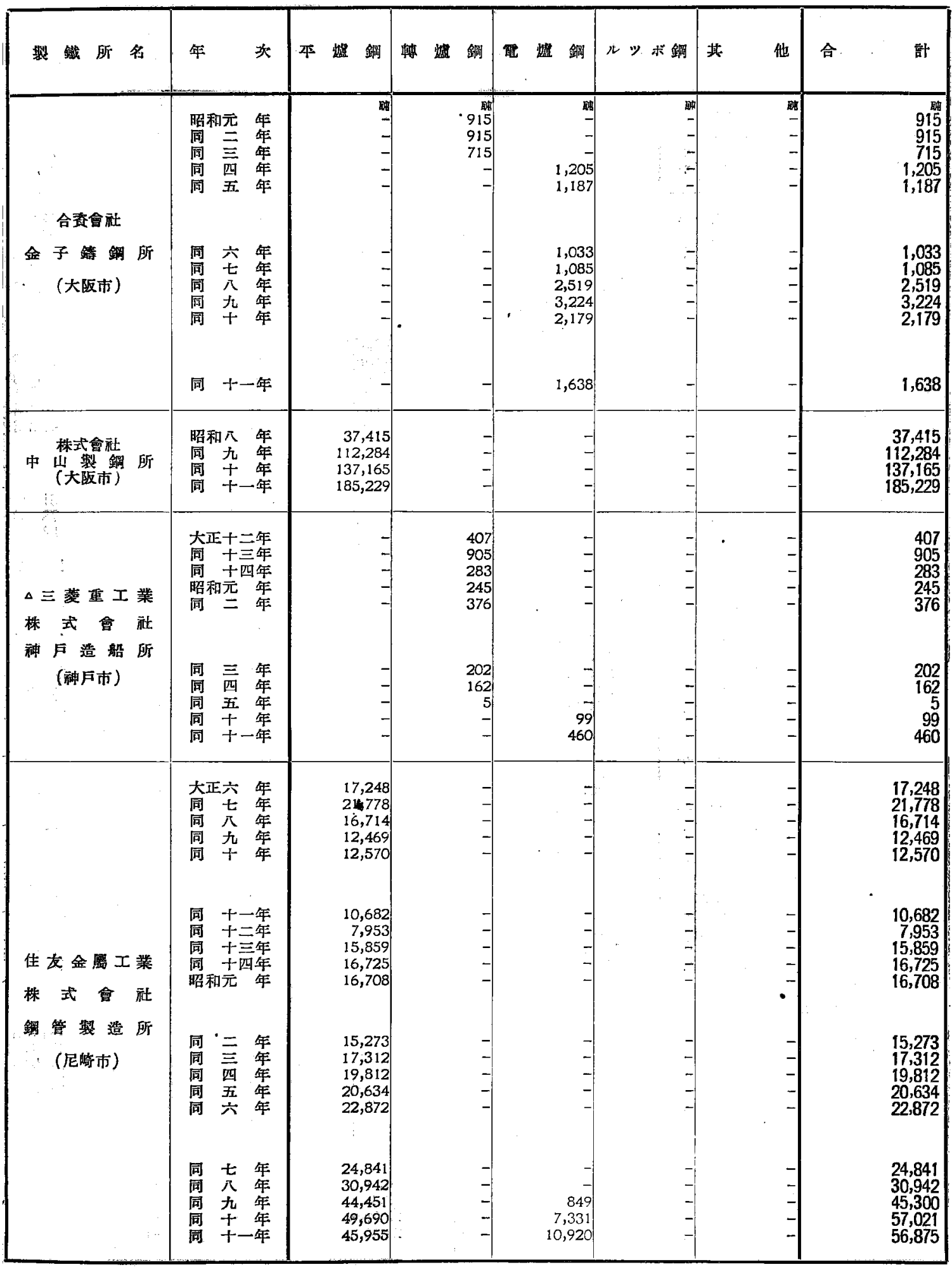




\section{鋼主要製鐵所別生產額調}

（其

十)

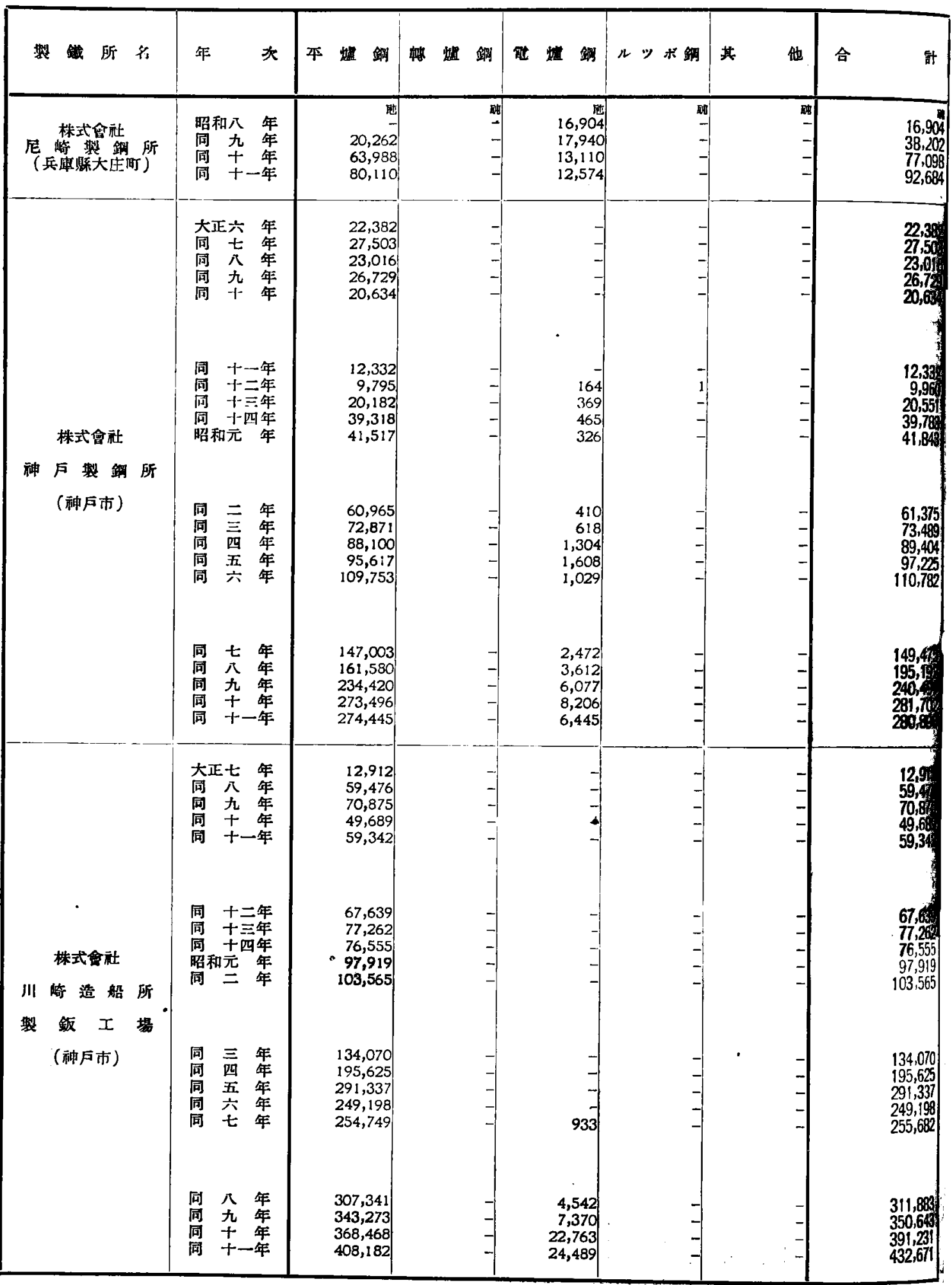


(其 十 一)

\begin{tabular}{|c|c|c|c|c|c|c|c|}
\hline 製 践 所 名 & 次 & 平 䗃 鎆 & 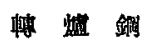 & 電 惯 鋼 & ルッポ銅 & 其 & 合 \\
\hline 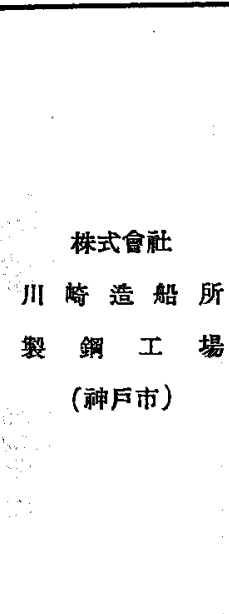 & 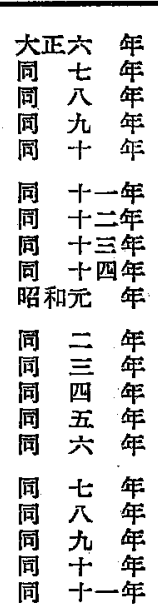 & $\begin{array}{r}189 \\
16,397 \\
28,711 \\
18,229 \\
17,198 \\
13,514 \\
12,406 \\
15,768 \\
19,112 \\
17,344 \\
18,685 \\
10,035 \\
6,097 \\
15,283 \\
10,017 \\
3,368 \\
1,348 \\
10,926 \\
16,289 \\
13,707 \\
25,976\end{array}$ & . & $\begin{array}{r}\text { 略 } \\
- \\
- \\
- \\
- \\
1,068 \\
1,602 \\
2,605 \\
2,047 \\
1,749 \\
1,800 \\
2,410 \\
1,619 \\
1,896 \\
2,383 \\
9,460 \\
8,40 \\
9,956\end{array}$ & 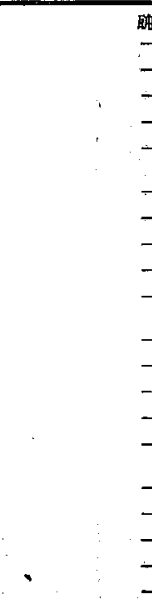 & $\begin{array}{l}x_{0} \\
- \\
- \\
- \\
- \\
- \\
- \\
- \\
- \\
- \\
- \\
- \\
- \\
- \\
- \\
- \\
- \\
- \\
-\end{array}$ & $\begin{array}{r}16,397 \\
16,71 \\
28,711 \\
18,229 \\
17,198 \\
13,514 \\
12,406 \\
15,768 \\
20,180 \\
18,946 \\
21,290 \\
12,082 \\
7,846 \\
17,083 \\
12,427 \\
4,987 \\
3,244 \\
13,309 \\
25,749 \\
22,177 \\
35,932\end{array}$ \\
\hline 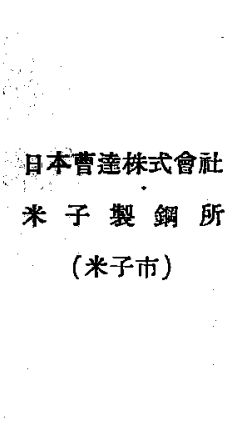 & 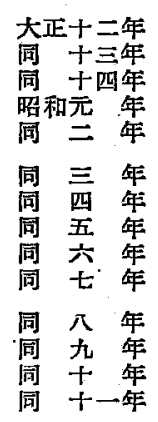 & $\begin{array}{l}- \\
- \\
-\end{array}$ & . & $\begin{array}{r}478 \\
631 \\
818 \\
609 \\
614 \\
628 \\
647 \\
644 \\
746 \\
771 \\
1,114 \\
1,042 \\
1,146 \\
1,059\end{array}$ & & $\begin{array}{l}- \\
- \\
- \\
- \\
- \\
- \\
- \\
- \\
- \\
- \\
-\end{array}$ & $\begin{array}{r}478 \\
631 \\
818 \\
609 \\
614 \\
628 \\
647 \\
644 \\
746 \\
771 \\
1,114 \\
1,042 \\
1,146 \\
1,059\end{array}$ \\
\hline $\begin{array}{l}\text { (6) } \\
\text { 株式會㕵 } \\
\text { 日立製 作 所 } \\
\text { 安 來 工 場 } \\
\text { (島根縣安來町) }\end{array}$ & 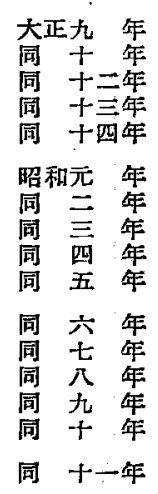 & $\begin{array}{l}- \\
- \\
-\end{array}$ & & $\begin{array}{r}460 \\
339 \\
266 \\
129 \\
212 \\
167 \\
265 \\
307 \\
336 \\
393 \\
399 \\
1,303 \\
2,468 \\
2,844 \\
2,546 \\
3,064\end{array}$ & C & $\begin{array}{l}- \\
- \\
- \\
- \\
- \\
- \\
- \\
- \\
- \\
- \\
- \\
-\end{array}$ & $\begin{array}{r}460 \\
339 \\
266 \\
129 \\
212 \\
167 \\
265 \\
307 \\
336 \\
393 \\
399 \\
1,33 \\
2,468 \\
2,844 \\
-2,546 \\
3,064\end{array}$ \\
\hline 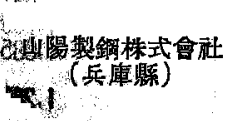 & $\begin{array}{l}\text { 昭和九 年 } \\
\text { 同 十 年 } \\
\text { 同 十一年 }\end{array}$ & - & & $\begin{array}{l}2,265 \\
3,675 \\
4,027\end{array}$ & & $\begin{array}{l}- \\
-\end{array}$ & $\begin{array}{l}2,265 \\
3,675 \\
4,027\end{array}$ \\
\hline
\end{tabular}

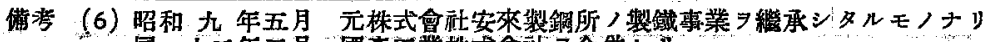

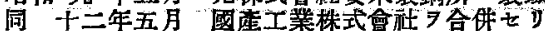




\section{鋼主要製鐵所別生產額調}

（其 + 二)

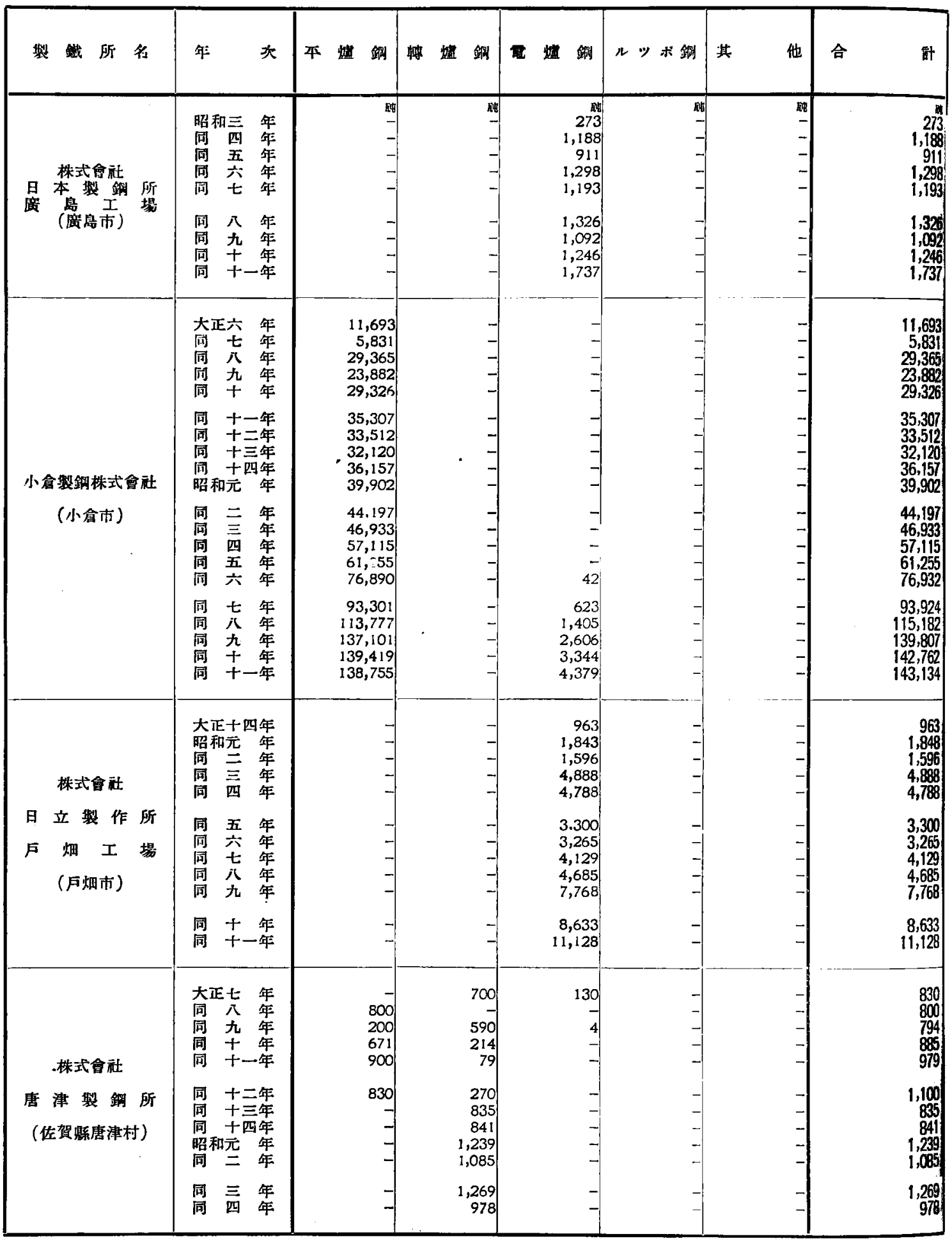


（其

\begin{tabular}{|c|c|c|c|c|c|c|c|}
\hline 帮 所 名 & 大 & 平 埴 鋮 & 轉 蛊 鋼 & 西 䖯 鋪 & ルッボ鋀 & 其 & 計 \\
\hline 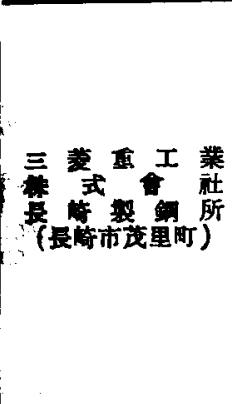 & 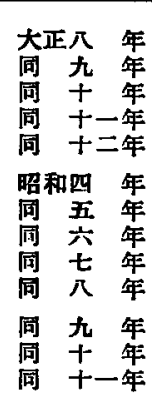 & $\begin{array}{r}3,331 \\
2,831 \\
5,651 \\
5,873 \\
5,374 \\
- \\
- \\
- \\
- \\
- \\
- \\
-\end{array}$ & $\begin{array}{l} \\
- \\
-1 \\
-1 \\
- \\
- \\
- \\
- \\
-\end{array}$ & $\begin{array}{r}\text { H } \\
- \\
- \\
- \\
- \\
1,898 \\
3,893 \\
4,385 \\
6,193 \\
12,383 \\
14,783 \\
14,783 \\
28,526\end{array}$ & $\begin{array}{l}\text { and } \\
- \\
- \\
- \\
- \\
- \\
- \\
- \\
- \\
- \\
- \\
-\end{array}$ & $\begin{array}{l}\text { 时 } \\
- \\
- \\
- \\
- \\
- \\
- \\
- \\
- \\
-\end{array}$ & $\begin{array}{r}3,331 \\
2,831 \\
5,651 \\
5,873 \\
5,374 \\
1,898 \\
3,893 \\
4,385 \\
6,193 \\
12,383 \\
14,783 \\
14,783 \\
28,526\end{array}$ \\
\hline 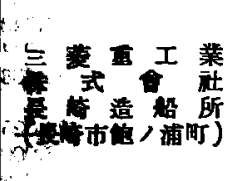 & $\begin{array}{l}\text { 大正十三年 } \\
\text { 同 十四年 } \\
\text { 照和元 年 } \\
\text { 同 三 年 } \\
\text { 同 三 年 } \\
\text { 同 四 年 }\end{array}$ & $\begin{array}{l}- \\
\overline{-} \\
\overline{-}\end{array}$ & $\begin{array}{l}-1 \\
z \\
- \\
-\end{array}$ & $\begin{array}{r}1,825 \\
1,229 \\
1,306 \\
1,206 \\
1,857 \\
701\end{array}$ & $\begin{array}{l}- \\
- \\
-\end{array}$ & $\begin{array}{l}- \\
- \\
- \\
- \\
-\end{array}$ & $\begin{array}{r}1,825 \\
1,229 \\
1,306 \\
1,206 \\
1,857 \\
701\end{array}$ \\
\hline 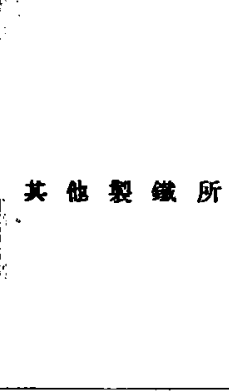 & 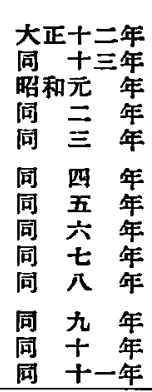 & - & $\begin{array}{r}- \\
\overline{-} \\
- \\
- \\
- \\
- \\
- \\
- \\
- \\
4,504\end{array}$ & $\begin{array}{r}704 \\
588 \\
- \\
- \\
645 \\
645 \\
2,865 \\
2,871 \\
4,244 \\
6,396 \\
11,631 \\
17,016 \\
32,123\end{array}$ & $\begin{array}{r}- \\
526 \\
135 \\
369 \\
379 \\
- \\
- \\
- \\
- \\
-\end{array}$ & $\begin{array}{r}408 \\
- \\
- \\
- \\
- \\
- \\
- \\
- \\
- \\
-\end{array}$ & $\begin{array}{r}704 \\
996 \\
526 \\
135 \\
369 \\
1,024 \\
2,865 \\
2,871 \\
4,244 \\
6,396 \\
11,631 \\
17,016 \\
42,354\end{array}$ \\
\hline 合 (丙 地) 䛎 & 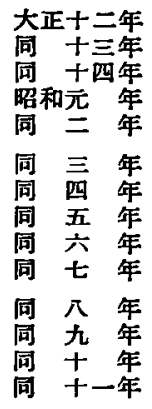 & $\begin{array}{r}847,725 \\
1,018,680 \\
1,208,580 \\
1,400,632 \\
1,569,552 \\
1,863,391 \\
2,238,198 \\
2,225,451 \\
1,828,823 \\
2,325,306 \\
3,056,347 \\
3,633,610 \\
4,459,737 \\
4,900,555\end{array}$ & $\begin{array}{r}103,474 \\
67,821 \\
74,923 \\
84,677 \\
87,998 \\
3,340 \\
1,210 \\
35 \\
- \\
940 \\
- \\
- \\
- \\
4,504\end{array}$ & $\begin{array}{r}6,292 \\
11,985 \\
15,496 \\
18,159 \\
26,517 \\
37,746 \\
52,654 \\
62,140 \\
52,765 \\
69,740 \\
139,561 \\
208,790 \\
241,669 \\
316,475\end{array}$ & \begin{tabular}{r|r|}
1,517 & 797 \\
1,204 \\
2,747 \\
1,175 \\
1,503 \\
1,778 \\
1,711 \\
1,537 \\
2,296 \\
2,192 \\
1,120 \\
1,200 \\
1,483
\end{tabular} & $\begin{array}{r}408 \\
- \\
- \\
- \\
- \\
- \\
- \\
- \\
- \\
- \\
- \\
- \\
-\end{array}$ & $\begin{array}{r}959,008 \\
1,099,691 \\
1,300,203 \\
1,506,215 \\
1,635,242 \\
1,905,980 \\
2,293,840 \\
2,289,337 \\
1,883,125 \\
2,398,282 \\
3,198,100 \\
3,843,520 \\
4,702,586 \\
5,223,017\end{array}$ \\
\hline 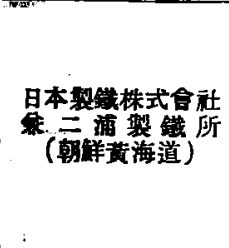 & $\begin{array}{l}\text { 大正八 年 } \\
\text { 同 } \\
\text { 同 年 } \\
\text { 同十一年 } \\
\text { 昭和八 年 } \\
\text { 同 九 年 } \\
\text { 同 十 年 } \\
\text { 同 十一年 }\end{array}$ & $\begin{array}{r}17,001 \\
34,211 \\
51,616 \\
8,389 \\
5,285 \\
59,697 \\
97,424 \\
87,014\end{array}$ & $\begin{array}{l}- \\
- \\
-1 \\
-1 \\
-1 \\
- \\
- \\
-\end{array}$ & $\begin{array}{l}-1 \\
-1 \\
-1\end{array}$ & 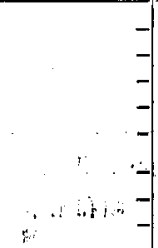 & $\begin{array}{l}- \\
- \\
- \\
- \\
- \\
- \\
-\end{array}$ & $\begin{array}{r}17,001 \\
34,211 \\
51,616 \\
8,389 \\
5,285 \\
59,697 \\
97,424 \\
87,014\end{array}$ \\
\hline 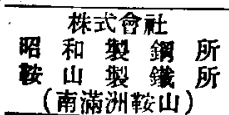 & $\begin{array}{l}\text { 照和十一年 } \\
\text { 十一年 }\end{array}$ & $\begin{array}{l}136,817 \\
344,051\end{array}$ & - & 9. & - & - & $\begin{array}{l}136,817 \\
344,051\end{array}$ \\
\hline
\end{tabular}


鋼 材圭要製 鐵

(其

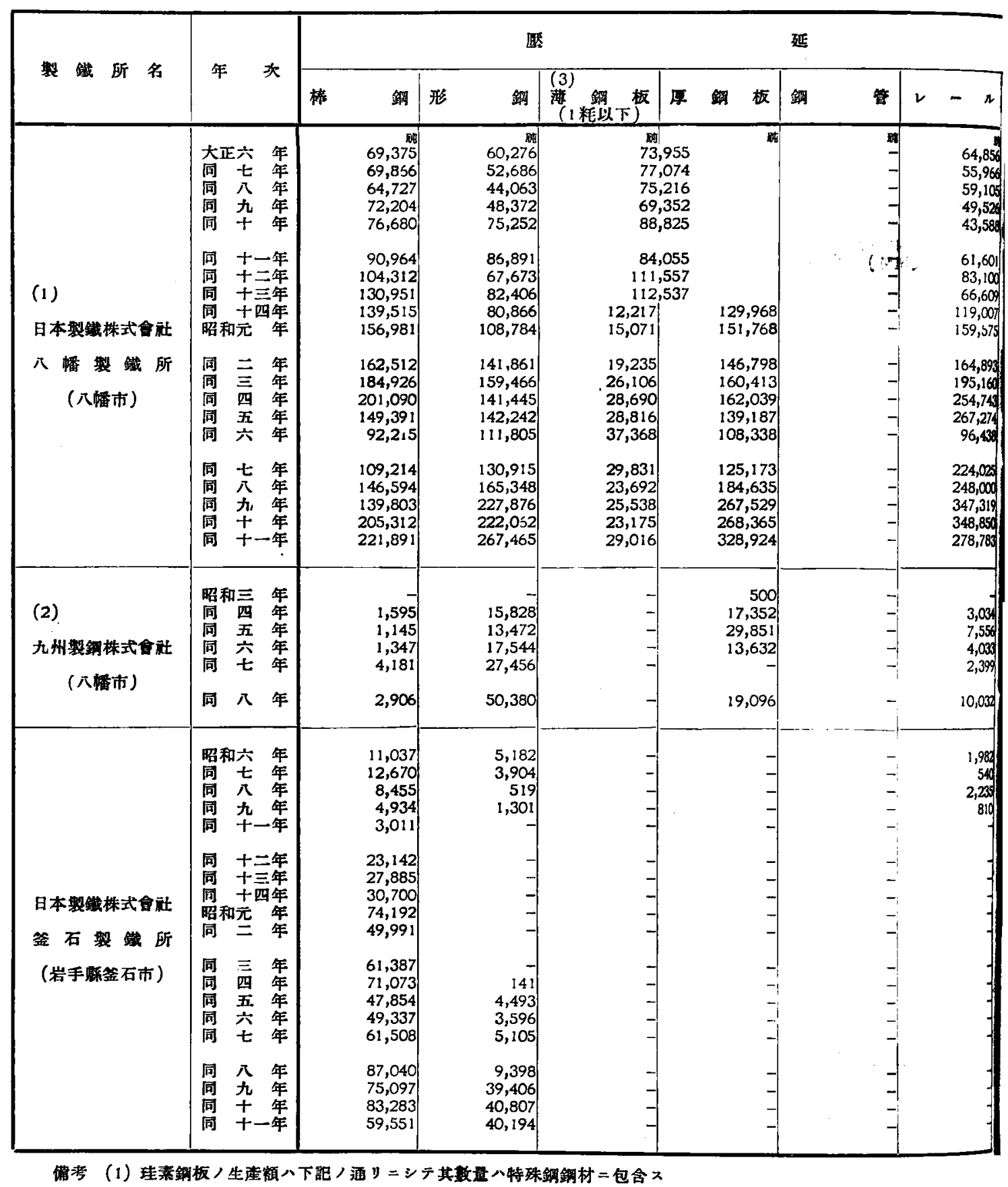

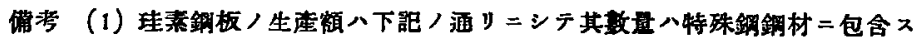

大正十四年 昭和元年 昭和二年 昭和三年 昭和四年

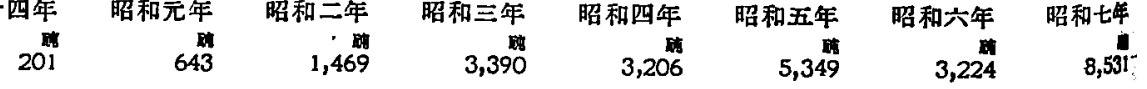

（2）昭和九年二月元九州製銅株式合社ノ製鐵事業》維承シタルモノナリ

（3）薄鎆板八昭和十年迄 0.7 粍以下 7 トレリ 


\section{所別生產額 調}

$-)$

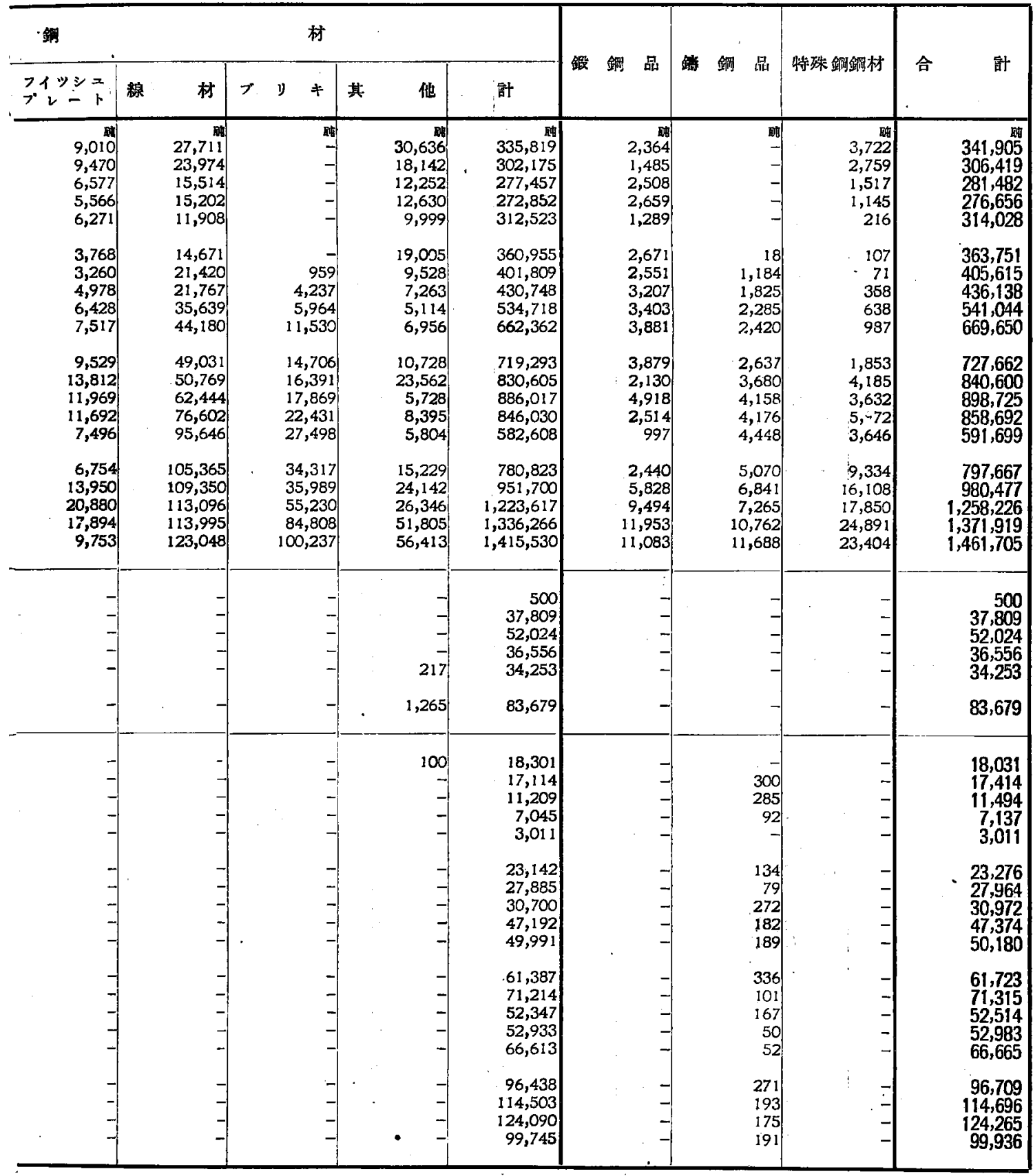
$\begin{array}{rrrr}\text { 昭和八年 } & \text { 昭和九年 } & \text { 昭和十年 } & \text { 昭和十一年 } \\ 14,551 & 16,718 & 24,447 & \text { 础 } \\ & & & 22,166\end{array}$ 
鋼材主要製 鐵

(其

\begin{tabular}{|c|c|c|c|c|c|c|c|c|}
\hline \multirow{2}{*}{ 製 䱛 所 名 } & \multirow{2}{*}{ 年 次 } & \multicolumn{4}{|c|}{ 短 } & \multicolumn{3}{|l|}{ 延 } \\
\hline & & 棒， & 形 & 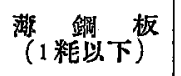 & 厚 飡 板 & 鋼 & $2-1$ & \\
\hline 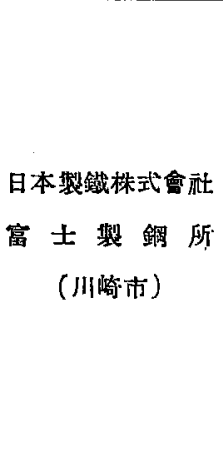 & 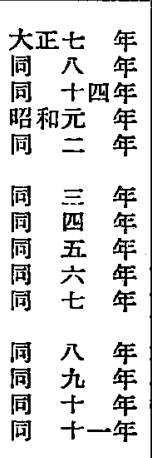 & $\begin{array}{r}\text { 啉 } \\
- \\
8,525 \\
21,324 \\
24,652 \\
34,041 \\
37,992 \\
26,904 \\
30,994 \\
41,408 \\
54,061 \\
55,41 \\
59,829 \\
61,226\end{array}$ & $\begin{array}{r}\text { z- } \\
- \\
- \\
- \\
- \\
993 \\
596 \\
838 \\
738 \\
89 \\
-\end{array}$ & $\begin{array}{l}\text { 傿- } \\
- \\
- \\
- \\
- \\
- \\
- \\
- \\
- \\
-\end{array}$ & $\begin{array}{l}\text { 胞 } \\
- \\
- \\
- \\
- \\
- \\
- \\
-\end{array}$ & $\begin{array}{l}0 \\
- \\
- \\
- \\
- \\
- \\
- \\
- \\
-\end{array}$ & & $\begin{array}{l}1 \\
-1 \\
-1 \\
-1 \\
-1 \\
-1 \\
-1\end{array}$ \\
\hline $\begin{array}{l}\text { 日本製鐵森式會社 } \\
\text { 大 阪 製 鐵 所 } \\
\text { · (大阪肪) }\end{array}$ & 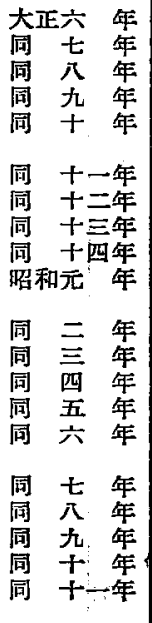 & $\begin{array}{r}5,512 \\
8,030 \\
7,952 \\
10,720 \\
10,145 \\
\\
12,690 \\
15,304 \\
18,485 \\
26,283 \\
35,991 \\
\\
38,632 \\
48,022 \\
51,128 \\
37,639 \\
38,068 \\
43,278 \\
57,933 \\
50,733 \\
70,190 \\
62,709\end{array}$ & $\begin{array}{r}- \\
- \\
- \\
- \\
- \\
- \\
- \\
- \\
1,142 \\
4,132 \\
2,039 \\
2,0302 \\
20,734 \\
22,161 \\
49,253\end{array}$ & $\begin{array}{r}- \\
- \\
61 \\
5 \\
-1 \\
-1 \\
y \\
- \\
-\end{array}$ & $\begin{array}{r}- \\
- \\
- \\
- \\
- \\
- \\
- \\
- \\
- \\
- \\
- \\
- \\
2,514 \\
14,467 \\
40,392 \\
44,970\end{array}$ & : & & $\begin{array}{l} \\
-1 \\
-1 \\
- \\
- \\
- \\
- \\
-\end{array}$ \\
\hline 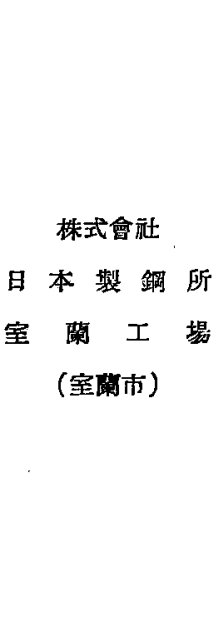 & 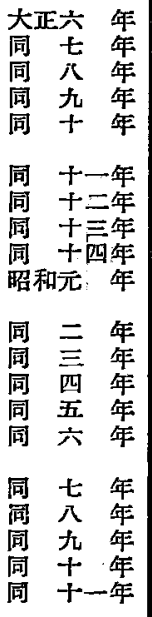 & $\begin{array}{r}1,493 \\
438 \\
1,507 \\
1,439 \\
2 \\
- \\
- \\
482 \\
897 \\
1,473 \\
244 \\
- \\
- \\
- \\
- \\
- \\
9,917 \\
10,191 \\
5,485 \\
2,756\end{array}$ & $\begin{array}{r}1,114 \\
230 \\
\overline{8} \\
6 \\
6 \\
- \\
- \\
- \\
118 \\
435 \\
- \\
- \\
- \\
- \\
- \\
- \\
- \\
- \\
- \\
-\end{array}$ & $\begin{array}{l}1 \\
-1 \\
-1 \\
-1 \\
-1 \\
-1\end{array}$ & - & $\begin{array}{l}- \\
- \\
- \\
- \\
- \\
- \\
-\end{array}$ & & $\begin{array}{l}- \\
- \\
- \\
- \\
- \\
- \\
-\end{array}$ \\
\hline
\end{tabular}




\section{所別生產額調}

二)

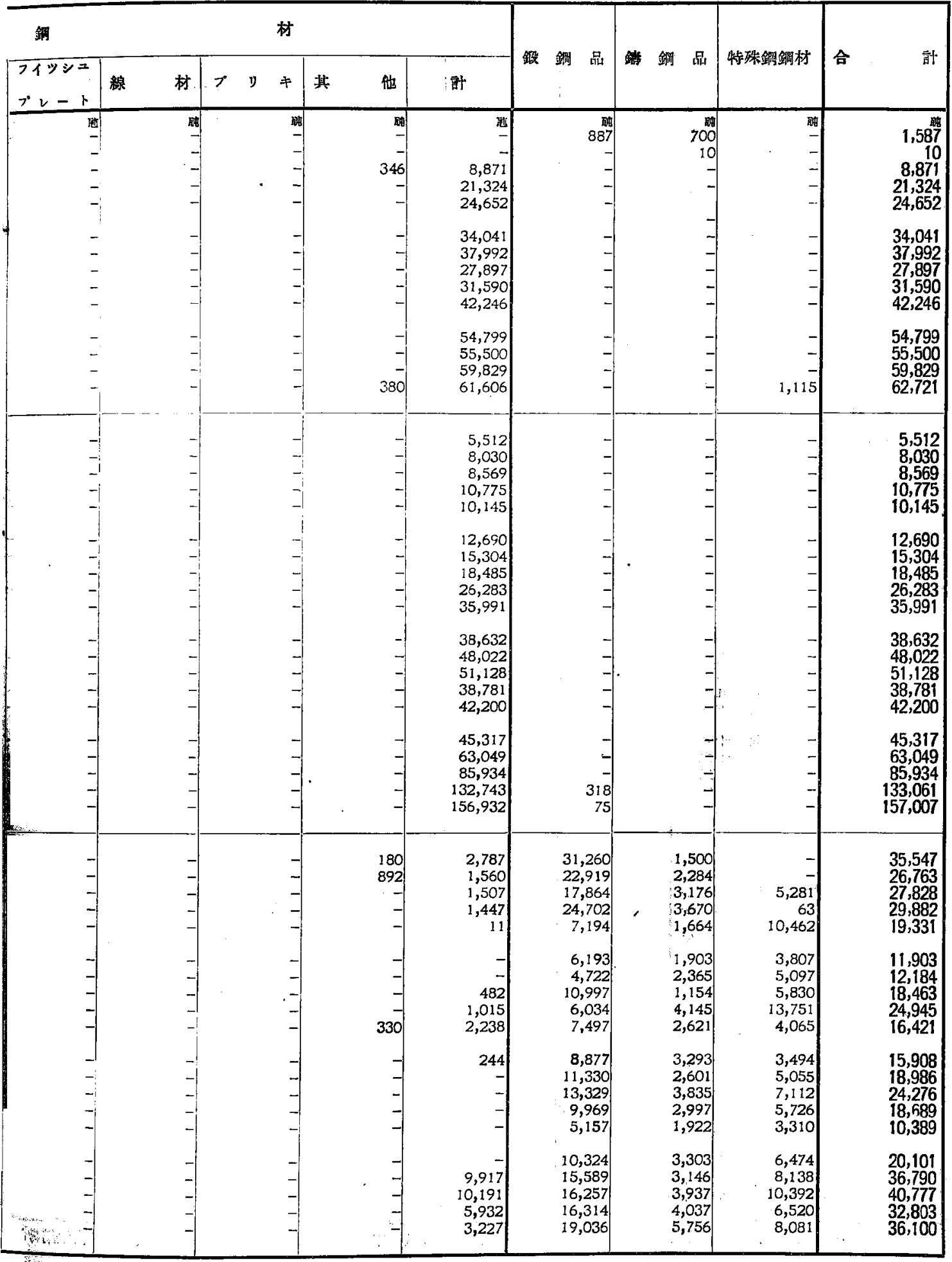


鋼 材主 要 製鐵

（其

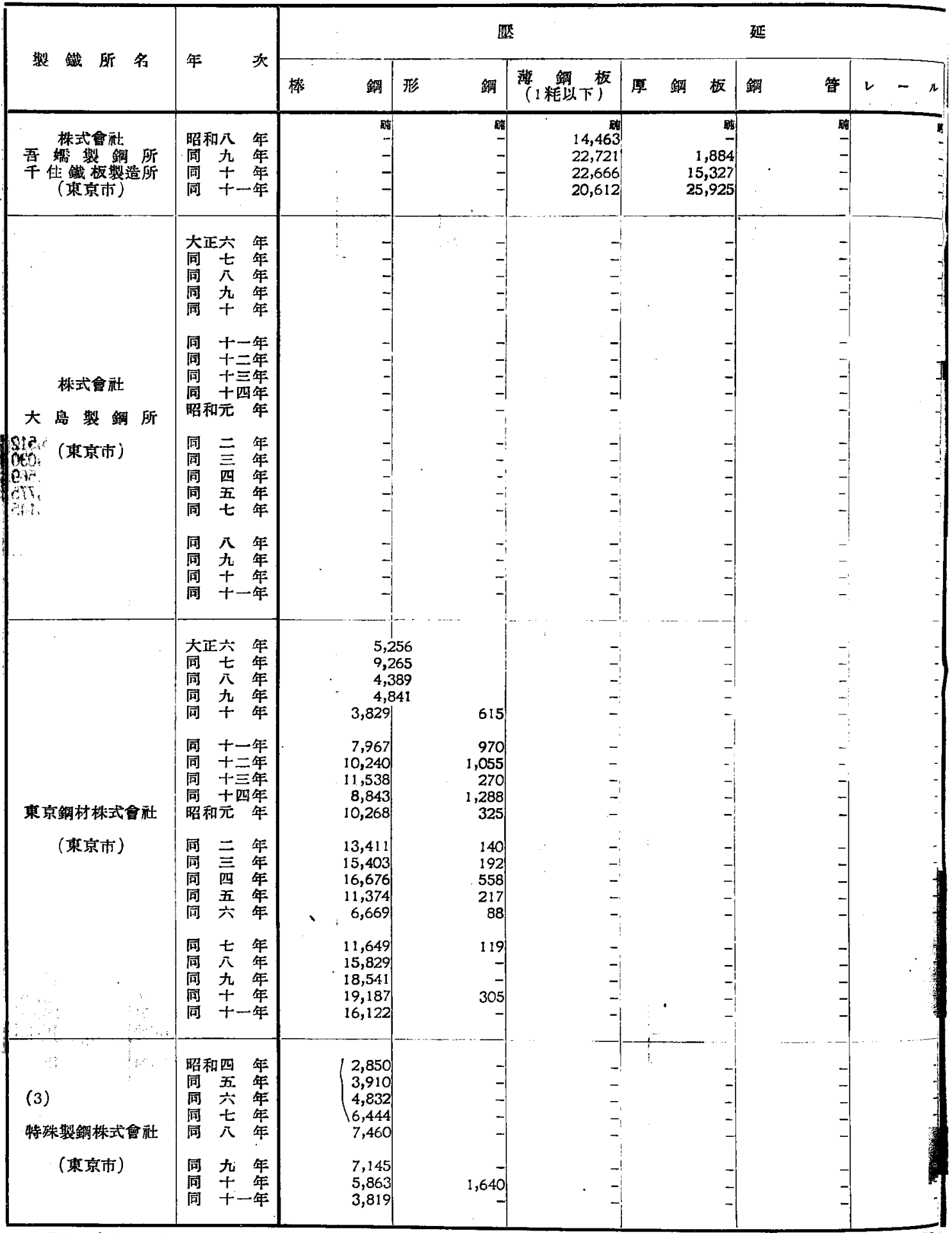

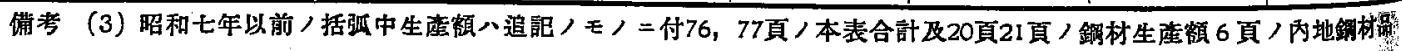




\section{所別生產額調}

\section{三)}

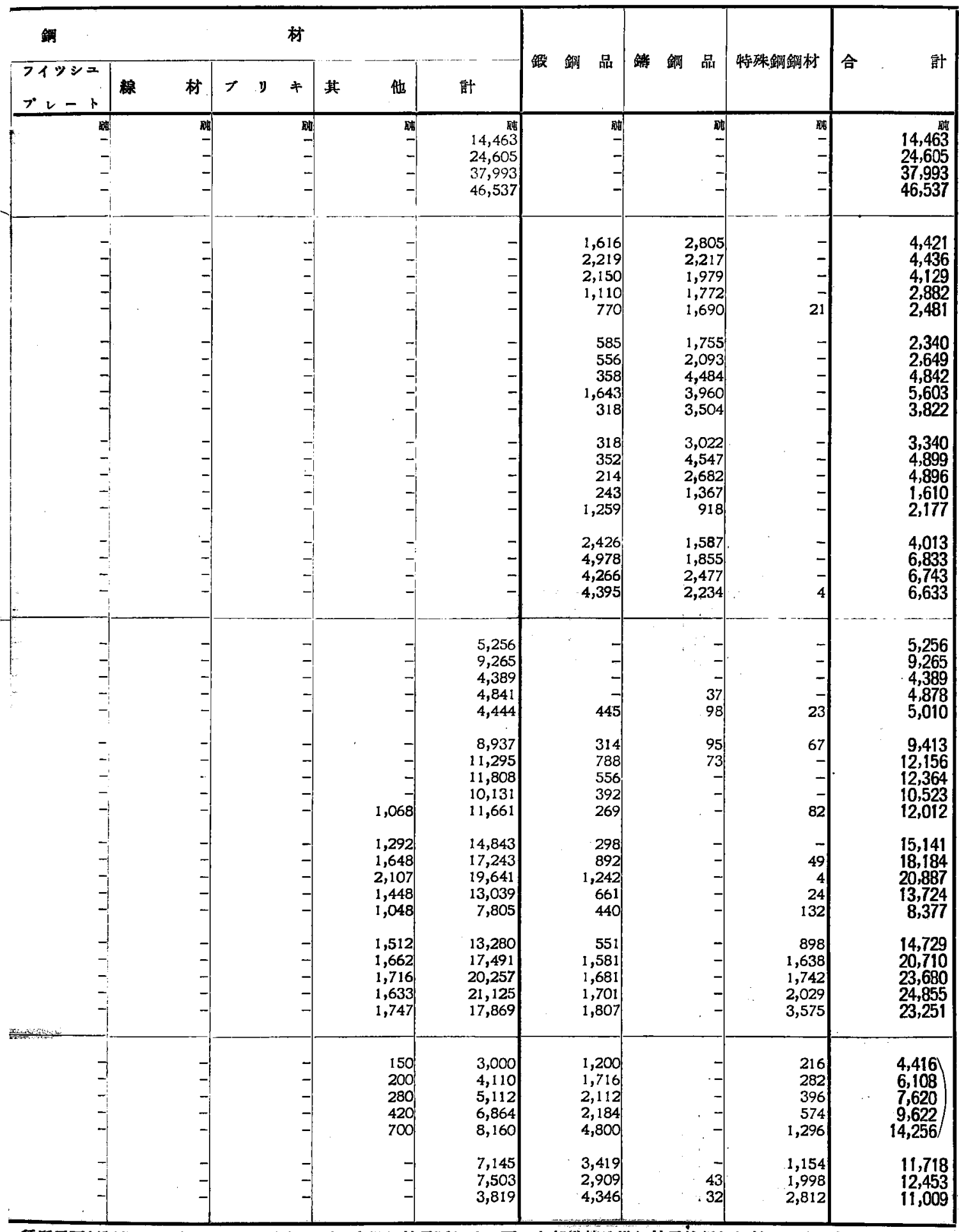


鋼材主要製鐵

(䨢

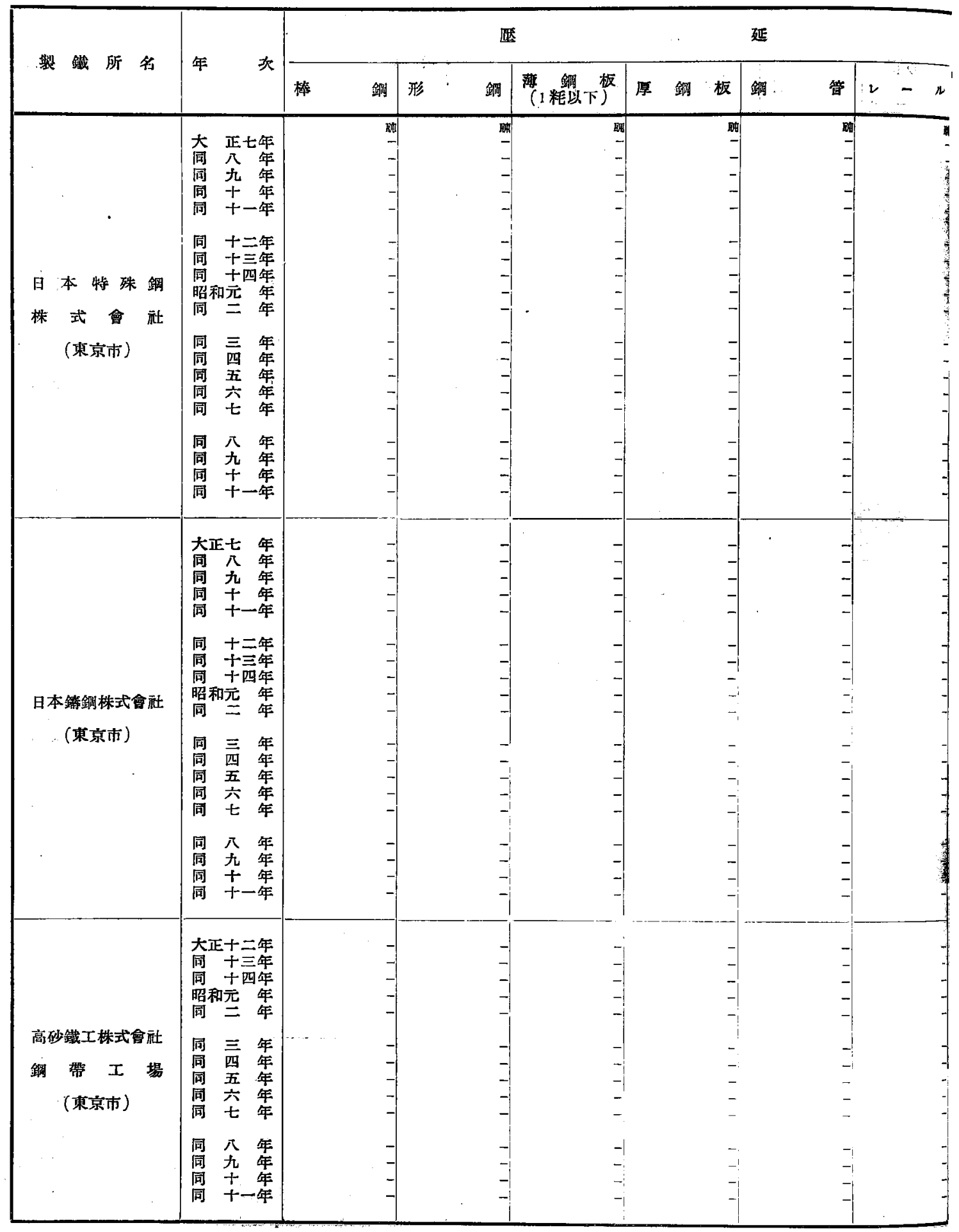




\section{所別生產額調}

四)

\begin{tabular}{|c|c|c|c|c|c|c|c|c|c|}
\hline 錋 & & 材 & & & & & & & \\
\hline $\begin{array}{l}\text { プンシュ } \\
\text { プレート. }\end{array}$ & 材 & ブ: キ & 他 & 剧 & & & & & \\
\hline $\begin{array}{l}\text { 口. } \\
- \\
- \\
- \\
- \\
- \\
- \\
- \\
- \\
- \\
- \\
- \\
- \\
- \\
- \\
- \\
- \\
- \\
-\end{array}$ & $\begin{array}{r}\text { 畹 } \\
- \\
- \\
- \\
- \\
- \\
- \\
- \\
- \\
- \\
- \\
- \\
- \\
- \\
- \\
- \\
- \\
-\end{array}$ & $\begin{array}{l}\text { nt } \\
- \\
- \\
- \\
- \\
- \\
- \\
- \\
- \\
- \\
- \\
- \\
- \\
- \\
- \\
-1\end{array}$ & $\begin{array}{r}- \\
- \\
- \\
319 \\
485 \\
117 \\
100 \\
132 \\
\\
157 \\
479 \\
433 \\
304 \\
393 \\
538 \\
724 \\
835 \\
681\end{array}$ & $\begin{array}{r}- \\
- \\
- \\
- \\
319 \\
485 \\
117 \\
100 \\
132 \\
157 \\
479 \\
433 \\
304 \\
393 \\
538 \\
724 \\
835 \\
681\end{array}$ & \begin{tabular}{r|}
$r$ \\
- \\
- \\
- \\
231 \\
236 \\
123 \\
172 \\
232 \\
\\
288 \\
427 \\
501 \\
392 \\
669 \\
\\
1,335 \\
1,095 \\
1,155 \\
1,092
\end{tabular} & $\begin{array}{r}7 \\
- \\
- \\
- \\
- \\
- \\
- \\
- \\
- \\
- \\
- \\
- \\
- \\
-\end{array}$ & $\begin{array}{r}120 \\
120 \\
957 \\
919 \\
989 \\
955 \\
\\
423 \\
554 \\
1,157 \\
1,263 \\
1,357 \\
1,804 \\
1,282 \\
1,248 \\
1,267 \\
2,564 \\
\\
4,550 \\
5,145 \\
5,388 \\
7,129\end{array}$ & & $\begin{array}{l}120 \\
957 \\
919 \\
989 \\
955 \\
973 \\
1,275 \\
1,397 \\
1,535 \\
1,721 \\
2,249 \\
2,188 \\
2,182 \\
1,963 \\
3,626 \\
6,423 \\
9,964 \\
7,378 \\
8,902\end{array}$ \\
\hline . & $\begin{array}{l}- \\
- \\
- \\
- \\
- \\
- \\
- \\
- \\
- \\
- \\
- \\
- \\
- \\
- \\
-\end{array}$ & $\begin{array}{l}-1 \\
-1 \\
-1 \\
-1 \\
- \\
- \\
- \\
- \\
- \\
- \\
- \\
-\end{array}$ & . & $\begin{array}{l}- \\
- \\
- \\
- \\
- \\
- \\
- \\
- \\
- \\
- \\
- \\
- \\
- \\
- \\
- \\
- \\
- \\
-\end{array}$ & $\begin{array}{l}- \\
- \\
- \\
- \\
- \\
- \\
- \\
- \\
- \\
- \\
- \\
- \\
-\end{array}$ & $\begin{array}{l}3,369 \\
2,102 \\
2,946 \\
2,603 \\
2,371 \\
\\
1,787 \\
2,231 \\
2,541 \\
3,030 \\
2,100 \\
\\
1,686 \\
1,472 \\
1,512 \\
1,670 \\
2,301 \\
\\
2,831 \\
3,630 \\
4,097 \\
3,217\end{array}$ & $\begin{array}{r}- \\
- \\
- \\
- \\
- \\
- \\
- \\
- \\
- \\
- \\
- \\
- \\
- \\
- \\
241 \\
- \\
770 \\
-\end{array}$ & & $\begin{array}{l}3,369 \\
2,102 \\
2,946 \\
2,603 \\
2,371 \\
1,787 \\
2,231 \\
2,541 \\
3,030 \\
2,100 \\
1,686 \\
1,472 \\
1,512 \\
1,670 \\
2,301 \\
3,072 \\
3,630 \\
4,867 \\
3,217\end{array}$ \\
\hline 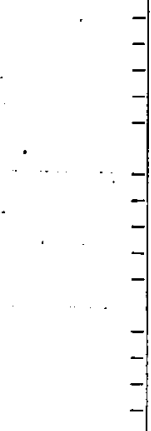 & $\begin{array}{l}- \\
- \\
- \\
- \\
- \\
- \\
- \\
- \\
- \\
-\end{array}$ & $\begin{array}{l}- \\
- \\
- \\
- \\
- \\
- \\
- \\
- \\
- \\
-\end{array}$ & $\begin{array}{l}1,300 \\
1,200 \\
2,400 \\
1,841 \\
2,100 \\
\\
3,000 \\
2,772 \\
2,230 \\
2,740 \\
3,313 \\
4,417 \\
5,109 \\
4,489 \\
6,801\end{array}$ & $\begin{array}{l}1,300 \\
1,200 \\
2,400 \\
1,841 \\
2,100 \\
3,000 \\
2,772 \\
2,230 \\
2,740 \\
3,313 \\
4,417 \\
5,109 \\
4,489 \\
6,801\end{array}$ & $\begin{array}{l}- \\
- \\
- \\
- \\
- \\
- \\
- \\
- \\
-\end{array}$ & - & $\begin{array}{l}- \\
- \\
- \\
- \\
-\end{array}$ & & $\begin{array}{l}1,300 \\
1,200 \\
2,400 \\
1,841 \\
2,100 \\
3,000 \\
2,772 \\
2,230 \\
2,740 \\
3,313 \\
4,417 \\
5,109 \\
4,489 \\
6,801 .\end{array}$ \\
\hline
\end{tabular}


鋼材主要製 鐵

（其

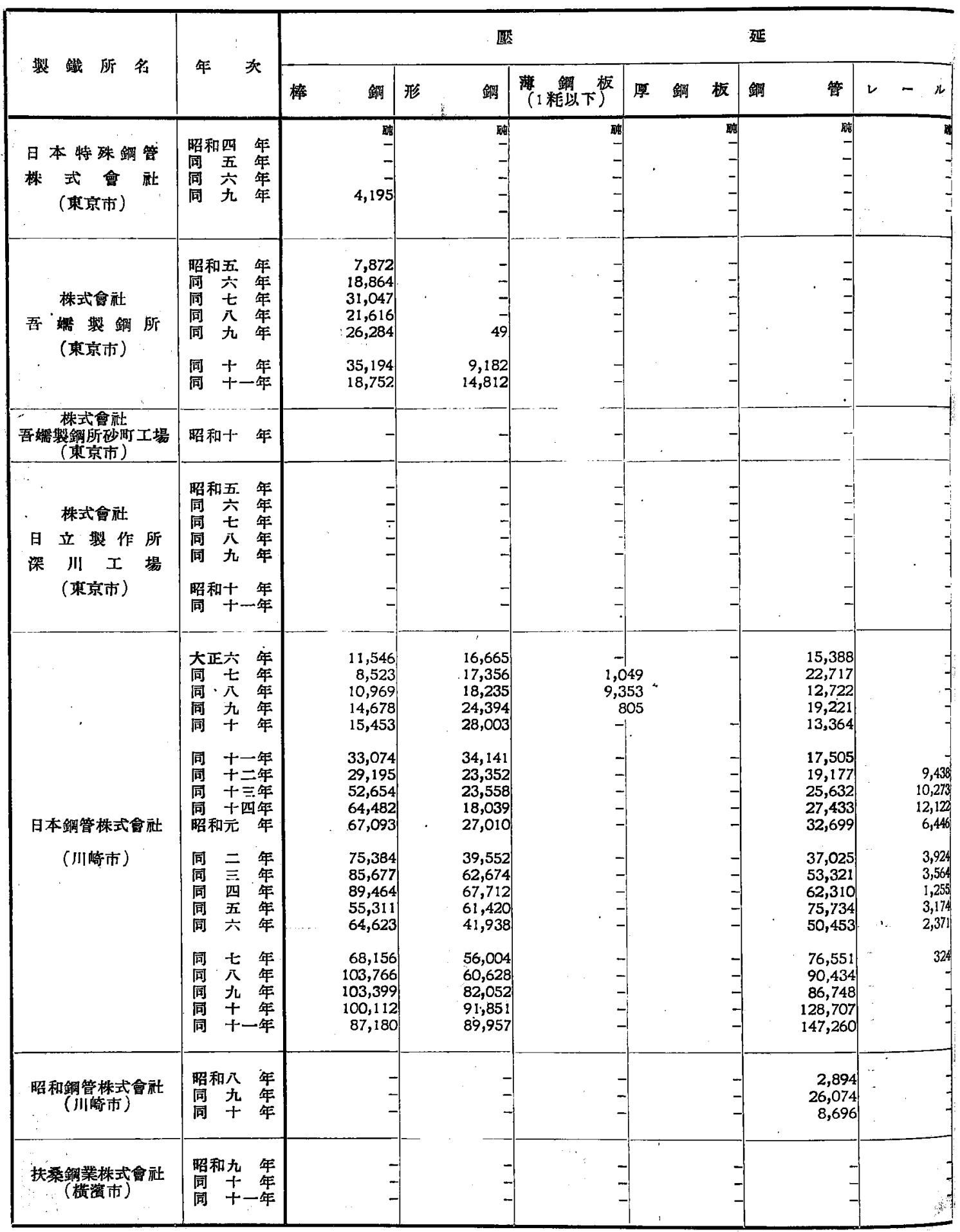




\section{所別生產額 調}

五)

\begin{tabular}{|c|c|c|c|c|c|c|c|c|}
\hline 錭 & & 材 & & & & & & \\
\hline 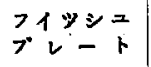 & 楾材。 & ブ: & 其 & 計 & 20. & 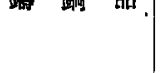 & 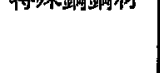 & 五 \\
\hline $\begin{array}{l}\text { 明 } \\
- \\
- \\
-\end{array}$ & $\begin{array}{l}\text { 昫 } \\
- \\
- \\
-\end{array}$ & $\begin{array}{l}\text { 做 } \\
- \\
- \\
- \\
-\end{array}$ & $\begin{array}{l}-1 \\
- \\
- \\
-\end{array}$ & $\begin{array}{r}\text { 湆 } \\
- \\
4,195\end{array}$ & $\begin{array}{l}\text { 础 } \\
- \\
-\end{array}$ & $\begin{array}{r}\text { Ry } \\
200 \\
200 \\
300 \\
1,291\end{array}$ & $\begin{array}{l}\text { at } \\
- \\
- \\
- \\
-\end{array}$ & $\begin{array}{r}200 \\
200 \\
300 \\
4,195 \\
1,291\end{array}$ \\
\hline $\begin{array}{l}- \\
- \\
- \\
-\end{array}$ & $\begin{array}{r}- \\
- \\
2,910 \\
9,208 \\
22,903 \\
39,718\end{array}$ & $\begin{array}{l}- \\
\bar{y} \\
- \\
-\end{array}$ & $\begin{array}{l}- \\
\\
- \\
- \\
- \\
-\end{array}$ & $\begin{array}{r}7,872 \\
18,864 \\
31,047 \\
30,526 \\
35,541 \\
\\
67,279 \\
73,282\end{array}$ & $\begin{array}{l}- \\
y \\
- \\
- \\
-\end{array}$ & $\begin{array}{r}- \\
677 \\
1,590 \\
2,081 \\
3,191 \\
2,947\end{array}$ & $\begin{array}{l}- \\
- \\
- \\
- \\
- \\
-\end{array}$ & $\begin{array}{r}7,872 \\
18,864 \\
31,724 \\
32,116 \\
37,622 \\
70,470 \\
76,229\end{array}$ \\
\hline - & & - & - & - & - & 455 & - & 455 \\
\hline $\begin{array}{l}- \\
- \\
- \\
-\end{array}$ & $\begin{array}{l}- \\
- \\
-\end{array}$ & $\begin{array}{l}- \\
- \\
-\end{array}$ & $\begin{array}{l}- \\
- \\
- \\
- \\
- \\
-\end{array}$ & $\begin{array}{l}- \\
- \\
- \\
- \\
-\end{array}$ & $\begin{array}{l}- \\
- \\
- \\
-\end{array}$ & $\begin{array}{r}438 \\
949 \\
1,909 \\
2,726 \\
2,275 \\
2,640 \\
5,377\end{array}$ & $\begin{array}{l}- \\
- \\
- \\
- \\
- \\
- \\
-\end{array}$ & $\begin{array}{r}438 \\
949 \\
1,909 \\
2,726 \\
2,275 \\
2,640 \\
5,377\end{array}$ \\
\hline $\begin{array}{r}- \\
- \\
- \\
- \\
- \\
-1 \\
107 \\
- \\
- \\
- \\
- \\
- \\
- \\
- \\
- \\
- \\
- \\
-\end{array}$ & $\begin{array}{l}- \\
- \\
- \\
- \\
- \\
- \\
- \\
- \\
- \\
- \\
- \\
- \\
- \\
- \\
- \\
-\end{array}$ & $\begin{array}{l}- \\
- \\
- \\
- \\
- \\
- \\
- \\
- \\
- \\
- \\
- \\
-\end{array}$ & $\begin{array}{r}- \\
143 \\
260 \\
614 \\
- \\
- \\
- \\
178 \\
242 \\
252 \\
209 \\
1,887 \\
1,751 \\
2,020 \\
4,900 \\
7,612 \\
9,756 \\
9,216 \\
10,269\end{array}$ & $\begin{array}{r}43,599 \\
49,788 \\
51,539 \\
59,712 \\
56,820 \\
\\
84,720 \\
81,162 \\
112,224 \\
122,254 \\
133,490 \\
\\
156,137 \\
205,445 \\
222,628 \\
197,390 \\
161,405 \\
\\
205,935 \\
262,440 \\
281,955 \\
329,886 \\
334,666\end{array}$ & $\begin{array}{l}- \\
- \\
- \\
- \\
- \\
- \\
\\
- \\
- \\
- \\
- \\
- \\
-\end{array}$ & $\begin{array}{l}- \\
- \\
- \\
- \\
- \\
- \\
- \\
- \\
- \\
- \\
- \\
- \\
- \\
- \\
- \\
-\end{array}$ & $\begin{array}{r}- \\
- \\
- \\
- \\
- \\
- \\
462 \\
- \\
- \\
- \\
- \\
-\end{array}$ & $\begin{array}{r}43,599 \\
49,788 \\
51,539 \\
59,712 \\
56,820 \\
84,720 \\
81,162 \\
112,224 \\
122,716 \\
133,490 \\
156,137 \\
205,445 \\
222,628 \\
197,390 \\
161,405 \\
205,935 \\
262,440 \\
281,955 \\
329,886 \\
334,666\end{array}$ \\
\hline & - & - & $\begin{array}{l}-1 \\
-1\end{array}$ & $\begin{array}{r}2,894 \\
26,074 \\
8,696\end{array}$ & $\begin{array}{l}- \\
- \\
-\end{array}$ & $\begin{array}{l}- \\
- \\
-\end{array}$ & $\begin{array}{l}- \\
-\end{array}$ & $\begin{array}{r}2,894 \\
26,074 \\
8,696\end{array}$ \\
\hline & - & $\begin{array}{r}5,931 \\
6,160 \\
13,768\end{array}$ & $\overline{-}$ & $\begin{array}{r}5,931 \\
6,160 \\
13,768\end{array}$ & - & $=$ & - & $\begin{array}{r}5,931 \\
6,160 \\
13,768\end{array}$ \\
\hline
\end{tabular}


58

鋼材主 要製 鐵

（其

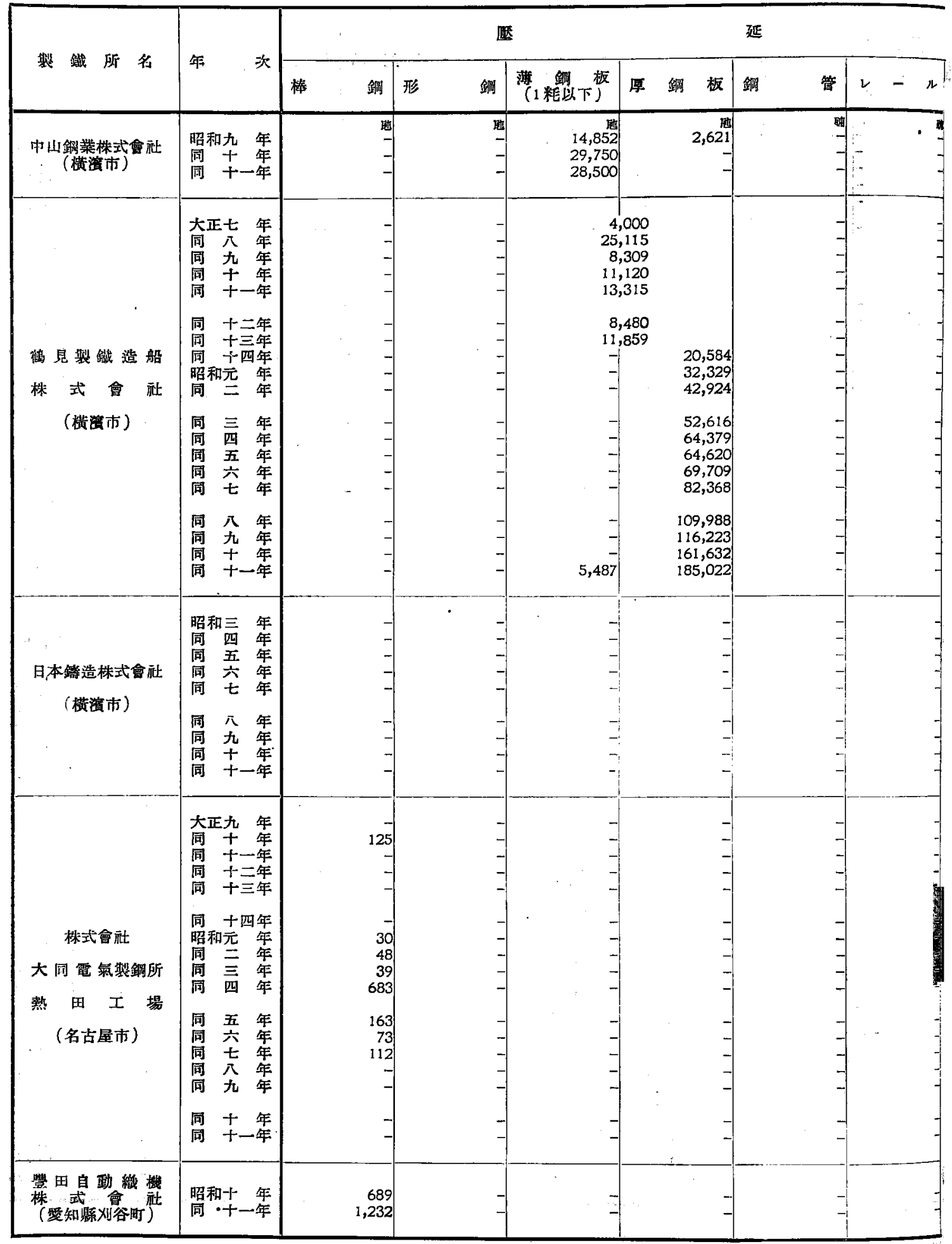




\section{所別生產額調}

六)

\begin{tabular}{|c|c|c|c|c|c|c|c|c|}
\hline 銅 & & 林 & & & & & & \\
\hline 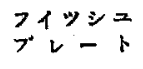 & 楾材 & $>\quad \neq \neq$ & 掑他 & 暗 & 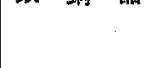 & 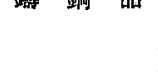 & 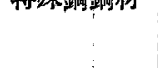 & 的 \\
\hline 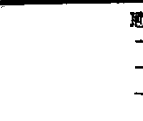 & 照 & 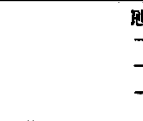 & $\begin{array}{l}\text { 溇 } \\
- \\
-\end{array}$ & $\begin{array}{l}17, \\
17,473 \\
29,750 \\
28,500\end{array}$ & $\begin{array}{l}\text { wat } \\
\frac{-1}{2}\end{array}$ & $\begin{array}{l}\frac{1}{1} \\
=\end{array}$ & $\begin{array}{l}\text { 㽖 } \\
- \\
-\end{array}$ & $\begin{array}{l}17,7 \\
29,730 \\
28,500\end{array}$ \\
\hline & $\begin{array}{l}- \\
- \\
- \\
- \\
- \\
\\
\end{array}$ & 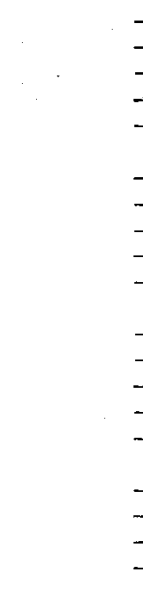 & $\begin{array}{l}= \\
= \\
= \\
= \\
- \\
= \\
- \\
- \\
- \\
=\end{array}$ & $\begin{array}{r}4,000 \\
25,115 \\
8,309 \\
11,120 \\
13,315 \\
8,480 \\
11,859 \\
20,584 \\
32,329 \\
42,924 \\
52,616 \\
64,379 \\
64,620 \\
69,709 \\
82,368 \\
109,988 \\
116,223 \\
161,632 \\
190,509\end{array}$ & $\begin{array}{l}- \\
\overline{-} \\
\overline{-}\end{array}$ & $\begin{array}{l}- \\
- \\
- \\
- \\
- \\
-\end{array}$ & 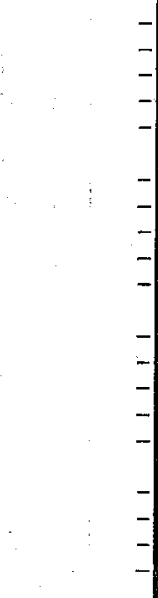 & $\begin{array}{r}4,000 \\
25,115 \\
8,309 \\
11,120 \\
13,315 \\
\mathbf{8}, 480 \\
11,859 \\
20,584 \\
32,329 \\
42,924 \\
52,616 \\
64,379 \\
64,620 \\
69,709 \\
82,368 \\
109,988 \\
116,223 \\
161,632 \\
190,509\end{array}$ \\
\hline & & & $\begin{array}{l}\bar{y} \\
\bar{y} \\
\overline{-}\end{array}$ & & 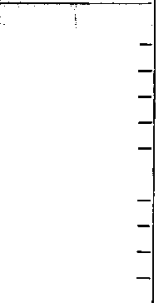 & $\begin{array}{r}132 \\
1,346 \\
865 \\
842 \\
1,305 \\
1,851 \\
2,415 \\
3,051 \\
3,430\end{array}$ & $\begin{array}{r}30 \\
6-1 \\
693 \\
448 \\
1,006 \\
870\end{array}$ & $\begin{array}{r}132 \\
1,376 \\
865 \\
911 \\
1,568 \\
2,299 \\
3,421 \\
3,921 \\
3,430\end{array}$ \\
\hline & -1 & & $\begin{array}{l}- \\
- \\
- \\
- \\
-\end{array}$ & $\begin{array}{r}125 \\
- \\
- \\
- \\
30 \\
48 \\
39 \\
683 \\
163 \\
73 \\
112 \\
- \\
- \\
-\end{array}$ & $\begin{array}{r}295 \\
138 \\
157 \\
114 \\
206 \\
643 \\
9 \\
588 \\
9 \\
523 \\
389 \\
242 \\
91 \\
- \\
-\end{array}$ & $\begin{array}{r}171 \\
160 \\
402 \\
569 \\
441 \\
1,329 \\
1,776 \\
2,151 \\
2,271 \\
2,773 \\
2,254 \\
2,187 \\
1,650 \\
2,026 \\
2,696 \\
1,549 \\
1,803\end{array}$ & $\begin{array}{r}- \\
16 \\
75 \\
158 \\
331 \\
608 \\
873 \\
863 \\
1,391 \\
807 \\
753 \\
803 \\
1,334 \\
1,405 \\
1,381\end{array}$ & $\begin{array}{r}466 \\
439 \\
-\quad 559 \\
758 \\
805 \\
2,303 \\
2,423 \\
3,660 \\
3,182 \\
5,370 \\
3,613 \\
2,255 \\
2,656 \\
3,360 \\
4,101 \\
2,930 \\
1,803\end{array}$ \\
\hline & & & & $\begin{array}{r}689 \\
1,232\end{array}$ & $\begin{array}{r}65 \\
166\end{array}$ & & $\begin{array}{r}287 \\
1,914\end{array}$ & $\begin{array}{l}1,041 \\
3,312\end{array}$ \\
\hline
\end{tabular}


60

銅材主要製鐵

（其

\begin{tabular}{|c|c|c|c|c|c|c|c|c|c|c|c|}
\hline \multirow{2}{*}{ 製 所 的 } & \multirow{2}{*}{ 年 羽 } & \multicolumn{10}{|c|}{ 延 } \\
\hline & & 棒 & 鍶 & 形 & 錯 & 薄 $(1$ 鍮以下 & 厚 鋼 & 板 & 铜 & 管 & $2-n$ \\
\hline 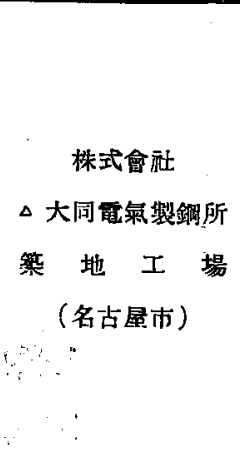 & 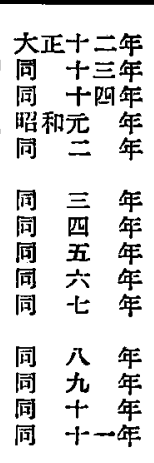 & & $\begin{array}{r}r \text { 朋 } \\
79 \\
264 \\
264 \\
61 \\
48 \\
106 \\
436 \\
255 \\
521 \\
875 \\
1,875 \\
2,33 \\
1,825\end{array}$ & & $\begin{array}{l}\text { 明 } \\
- \\
- \\
- \\
- \\
- \\
- \\
- \\
- \\
- \\
-\end{array}$ & . & & $\begin{array}{l}\text { ㅁot } \\
\overline{-} \\
\overline{-} \\
- \\
- \\
- \\
- \\
- \\
- \\
- \\
- \\
-\end{array}$ & & 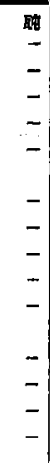 & $\begin{array}{l}\cdots \\
\cdots\end{array}$ \\
\hline 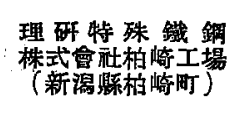 & $\begin{array}{l}\text { 照和十年 } \\
\text { 同 }+ \text { 年 }\end{array}$ & & 120 & & - & . & & - & & $\overline{-}$ & \\
\hline $\begin{array}{c} \\
\text { 小 株式會社 } \\
\text { (百川綦小松町) }\end{array}$ & 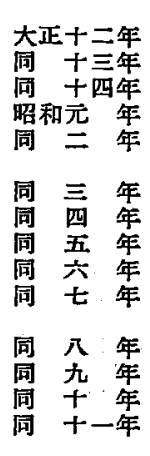 & & $\begin{array}{l}- \\
y \\
- \\
- \\
- \\
- \\
- \\
- \\
- \\
-\end{array}$ & & $\begin{array}{l}- \\
- \\
- \\
-\end{array}$ & . & & $\begin{array}{l}- \\
\bar{y} \\
-\end{array}$ & & $\begin{array}{l}- \\
\bar{z} \\
\overline{-} \\
- \\
- \\
z \\
-\end{array}$ & - \\
\hline 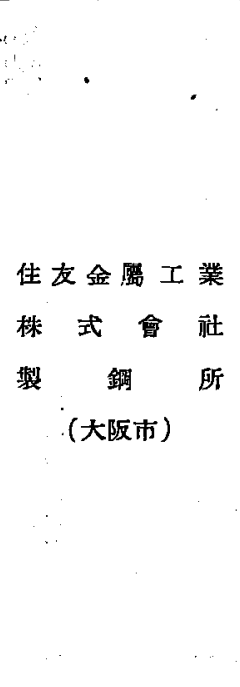 & 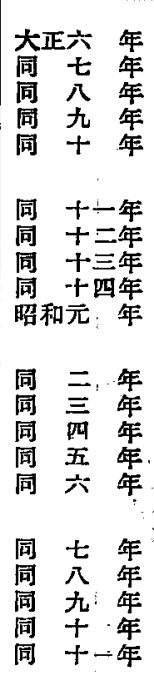 & & $\begin{array}{l}- \\
-\end{array}$ & & $\begin{array}{l}- \\
- \\
-\end{array}$ & 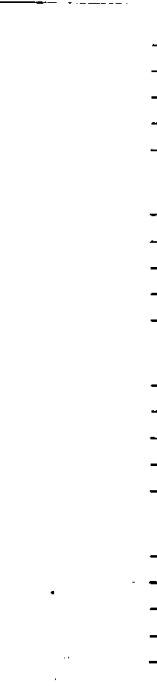 & & $\begin{array}{l}z \\
= \\
\end{array}$ & & 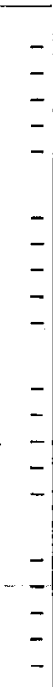 & \\
\hline
\end{tabular}




\section{所別生 產 額 調}

七)

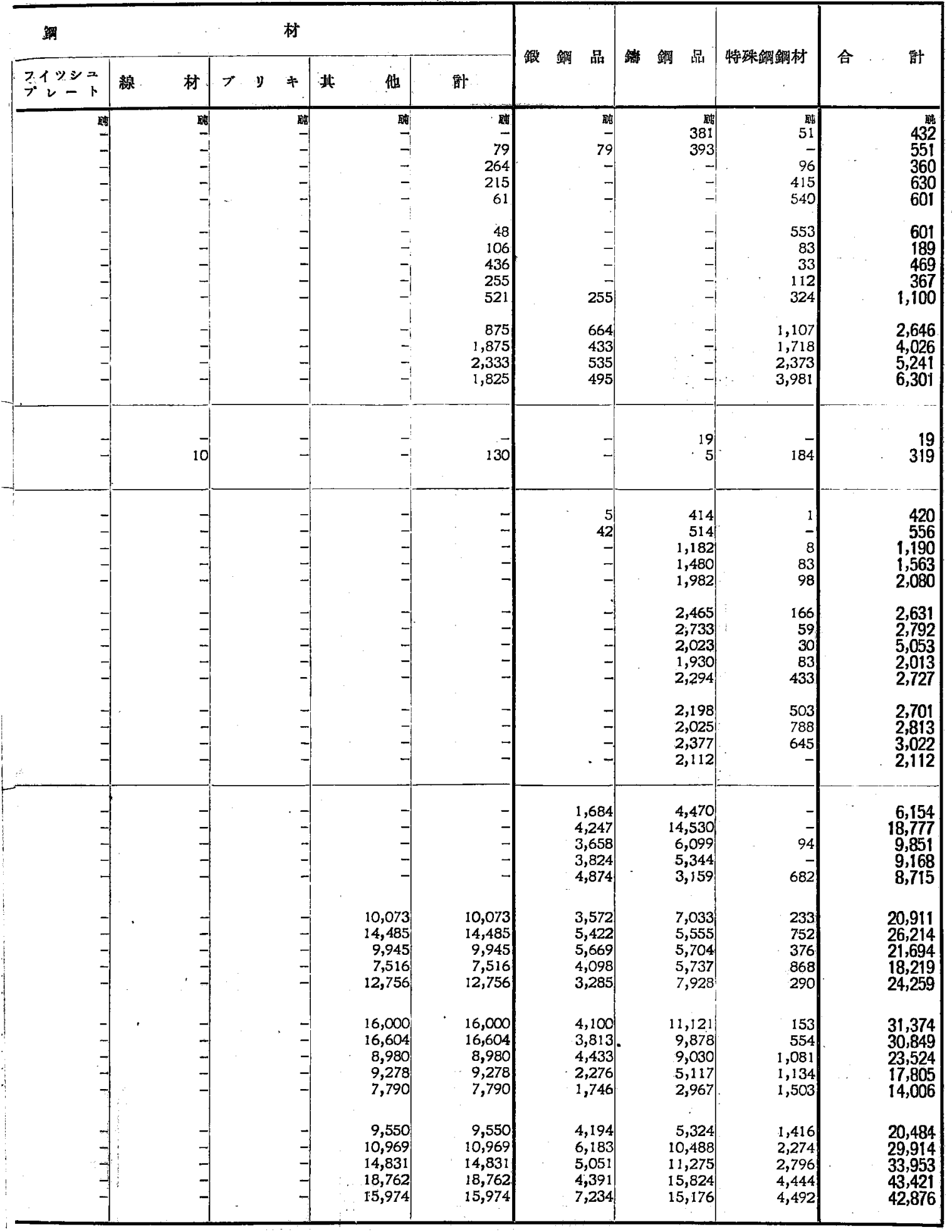


(其

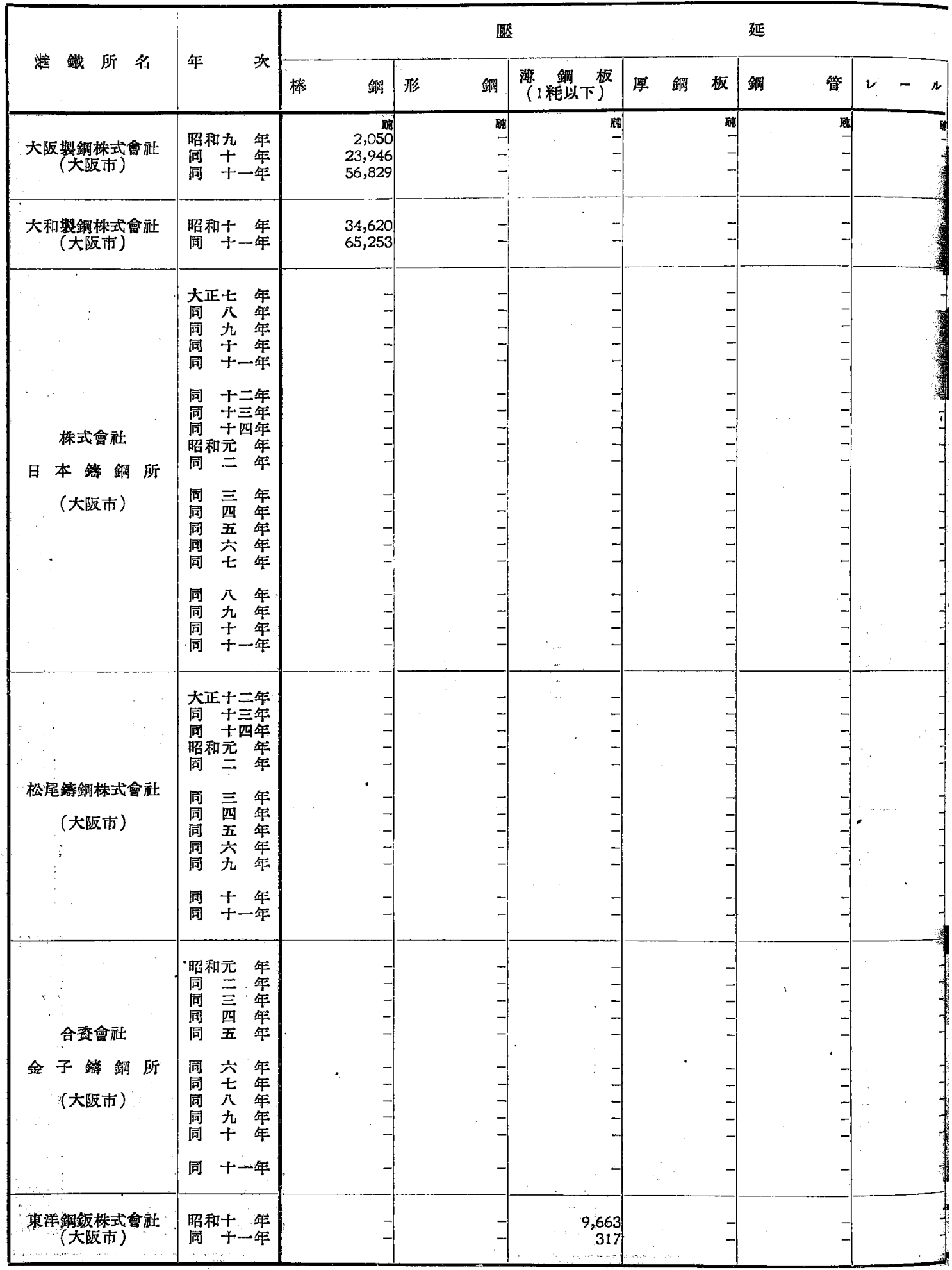




\section{所別生產額調}

त)

\begin{tabular}{|c|c|c|c|c|c|c|c|c|}
\hline 剑 & & 材 & & & & & & \\
\hline $\begin{array}{l}71 \% シ= \\
7 *-ト\end{array}$ & 楾材 & $\neg y \neq$ & 其他 & 計 & 政 & 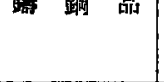 & 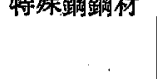 & 台 百 \\
\hline- & $\begin{array}{l}m \\
z\end{array}$ & - & $=$ & $\begin{array}{r}2,050 \\
23,946 \\
56,829\end{array}$ & $\begin{array}{l}\text { 明 } \\
- \\
-\end{array}$ & $\begin{array}{l}\text { nt } \\
- \\
-\end{array}$ & $\begin{array}{l}\text { 酎 } \\
- \\
-\end{array}$ & $\begin{array}{r}2,050 \\
23,946 \\
56,829\end{array}$ \\
\hline- & - & $\therefore$ & - & $\begin{array}{l}34,620 \\
65,253\end{array}$ & - & - & - & $\begin{array}{l}34,620 \\
65,253\end{array}$ \\
\hline $\begin{array}{l}- \\
- \\
- \\
-\end{array}$ & 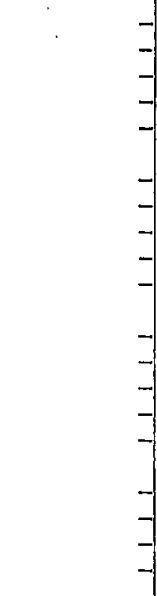 & $\begin{array}{l}- \\
- \\
- \\
- \\
- \\
- \\
- \\
- \\
- \\
- \\
- \\
- \\
- \\
- \\
-\end{array}$ & $\begin{array}{l}- \\
= \\
= \\
- \\
= \\
= \\
- \\
- \\
- \\
- \\
- \\
- \\
- \\
-\end{array}$ & $\begin{array}{l}- \\
= \\
- \\
- \\
= \\
= \\
- \\
- \\
- \\
- \\
- \\
- \\
- \\
- \\
- \\
-\end{array}$ & $\begin{array}{l}- \\
- \\
\overline{-} \\
- \\
\overline{-} \\
- \\
- \\
- \\
- \\
- \\
- \\
- \\
- \\
-\end{array}$ & $\begin{array}{r}3,314 \\
1,734 \\
2,117 \\
1,652 \\
1,455 \\
1,787 \\
1,502 \\
1,326 \\
1,501 \\
1,355 \\
1,496 \\
1,786 \\
902 \\
919 \\
1,603 \\
2,140 \\
2,065 \\
1,933 \\
2,099 \\
\end{array}$ & $\begin{array}{r}- \\
- \\
- \\
- \\
- \\
- \\
7 \\
27 \\
- \\
- \\
- \\
- \\
- \\
88 \\
-\end{array}$ & $\begin{array}{r}3,314 \\
1,734 \\
2,117 \\
1,652 \\
1,455 \\
1,787 \\
1,502 \\
1,326 \\
1,501 \\
1,362 \\
1,523 \\
1,786 \\
902 \\
919 \\
1,603 \\
2,140 \\
2,065 \\
2,021 \\
2,099\end{array}$ \\
\hline- & $\begin{array}{l}- \\
- \\
- \\
- \\
- \\
- \\
- \\
-\end{array}$ & $\begin{array}{l}- \\
- \\
- \\
- \\
-\end{array}$ & $\begin{array}{l}- \\
- \\
- \\
- \\
- \\
- \\
- \\
- \\
-\end{array}$ & $\begin{array}{l}- \\
- \\
- \\
- \\
- \\
- \\
- \\
- \\
- \\
-\end{array}$ & $\begin{array}{l}- \\
- \\
- \\
- \\
= \\
= \\
- \\
-\end{array}$ & $\begin{array}{r}866 \\
510 \\
488 \\
1,154 \\
748 \\
1,557 \\
963 \\
588 \\
158 \\
838 \\
\\
2,033 \\
1,132\end{array}$ & $\begin{array}{r}2 \\
27 \\
- \\
- \\
- \\
- \\
- \\
- \\
- \\
- \\
- \\
-\end{array}$ & $\begin{array}{r}868 \\
540 \\
488 \\
1,154 \\
748 \\
1,557 \\
963 \\
588 \\
158 \\
838 \\
2,033 \\
1,132\end{array}$ \\
\hline - & $\begin{array}{l}- \\
- \\
- \\
-\end{array}$ & $\begin{array}{l}- \\
- \\
- \\
-\end{array}$ & $\begin{array}{l}- \\
- \\
- \\
- \\
- \\
- \\
- \\
-\end{array}$ & $\begin{array}{l}- \\
- \\
- \\
- \\
- \\
- \\
- \\
-\end{array}$ & $\begin{array}{l}- \\
\overline{-} \\
-\end{array}$ & $\begin{array}{r}- \\
- \\
- \\
- \\
469 \\
1,527 \\
1,849 \\
2,177 \\
1,636\end{array}$ & $\begin{array}{r}915 \\
915 \\
695 \\
726 \\
966 \\
854 \\
539 \\
992 \\
1,375 \\
1,978 \\
\end{array}$ & $\begin{array}{r}915 \\
915 \\
695 \\
726 \\
966 \\
854 \\
1,008 \\
2,519 \\
3,224 \\
4,155 \\
1,636\end{array}$ \\
\hline & 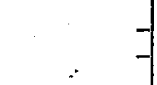 & $\begin{array}{r}3,506 \\
22,006 \\
\end{array}$ & - & $\begin{array}{l}13,169 \\
22,323\end{array}$ & - & & - & $\begin{array}{l}13,169 \\
22,323\end{array}$ \\
\hline
\end{tabular}


鋼材主要製鐵

（其

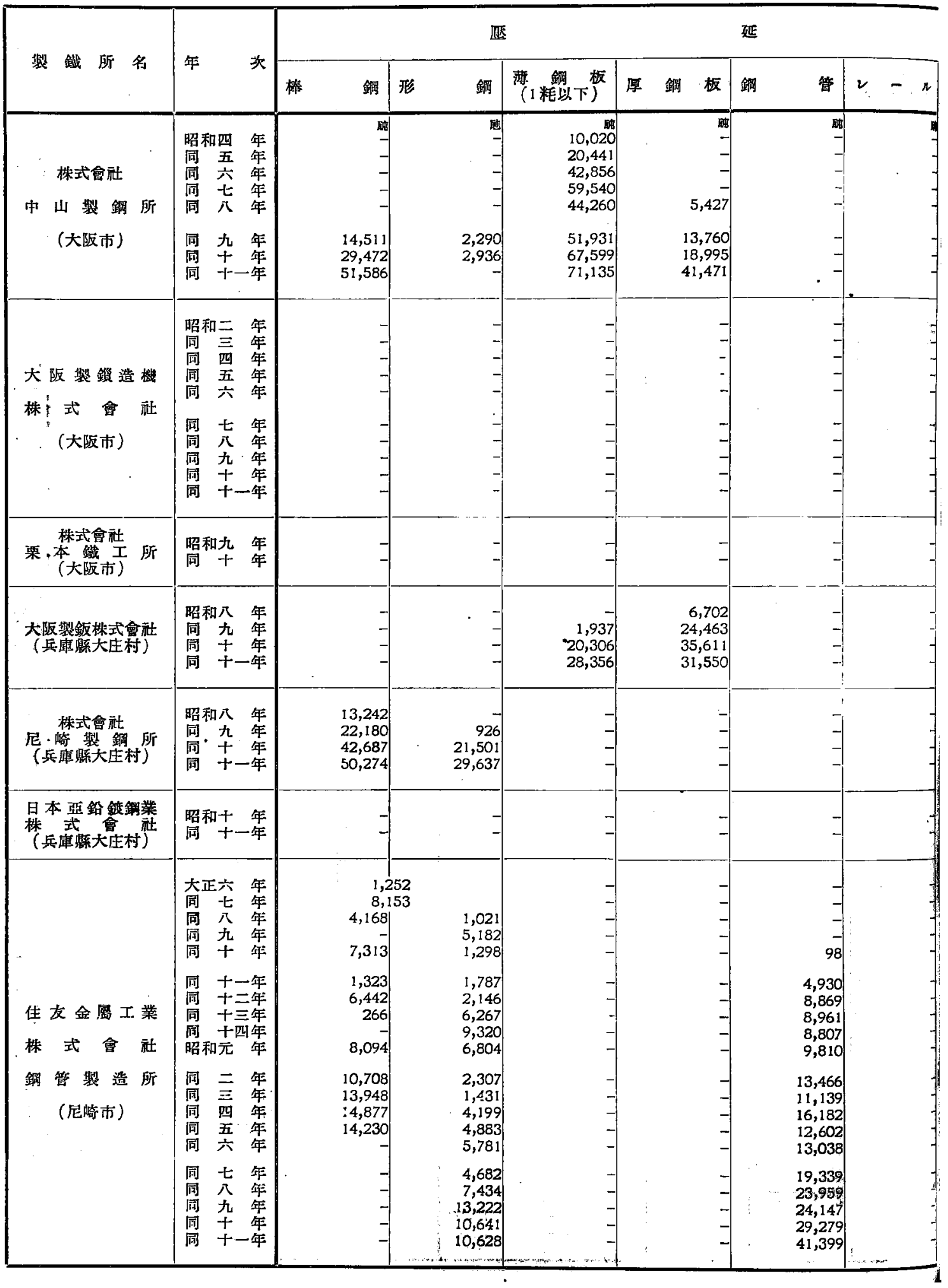




\section{所別生產額 調}

九）

\begin{tabular}{|c|c|c|c|c|c|c|c|c|}
\hline 鳎 & & 材 & & & & & & \\
\hline 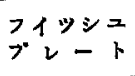 & 線 & $7 y \neq$ & 其 & 咶 & 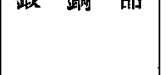 & 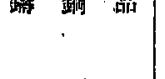 & 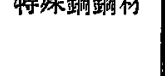 & 合 \\
\hline & $\begin{array}{r} \\
14,480 \\
32,772 \\
51,300 \\
77,601\end{array}$ & $\begin{array}{r}\text { 매 } \\
- \\
- \\
- \\
- \\
1,058\end{array}$ & $\begin{array}{l}\text { ab } \\
- \\
- \\
- \\
- \\
- \\
-\end{array}$ & \begin{tabular}{r|}
10,020 \\
20,441 \\
42,856 \\
59,540 \\
64,167 \\
115,264 \\
170,302 \\
242,851
\end{tabular} & $\begin{array}{l}7 \\
7\end{array}$ & $\begin{array}{l}= \\
= \\
=\end{array}$ & $\begin{array}{l}= \\
= \\
- \\
= \\
-\end{array}$ & $\begin{array}{r}10,020 \\
20,441 \\
42,856 \\
59,540 \\
64,167 \\
115,264 \\
170,302 \\
242,851\end{array}$ \\
\hline & & & $\begin{array}{l}\overline{-} \\
\overline{-}\end{array}$ & $\begin{array}{l}\bar{z} \\
\bar{z}\end{array}$ & I & $\begin{array}{r}93 \\
222 \\
401 \\
263 \\
293 \\
252 \\
421 \\
757 \\
1,981 \\
1,099\end{array}$ & $\begin{array}{r}129 \\
1 \\
19 \\
45 \\
18 \\
353 \\
325 \\
706 \\
- \\
-\end{array}$ & $\begin{array}{r}222 \\
222 \\
420 \\
308 \\
311 \\
605 \\
746 \\
1,463 \\
1,981 \\
1,099\end{array}$ \\
\hline & & - & - & & & $\begin{array}{l}1,202 \\
1,701\end{array}$ & $\begin{array}{r}49 \\
232\end{array}$ & $\begin{array}{l}1,251 \\
1,933\end{array}$ \\
\hline & & & $y$ & $\begin{array}{r}6,702 \\
26,400 \\
55,917 \\
59,906\end{array}$ & - & & $\begin{array}{l}- \\
-\end{array}$ & $\begin{array}{r}6,702 \\
26,400 \\
55,917 \\
59,906\end{array}$ \\
\hline & & $\begin{array}{l}- \\
-\end{array}$ & $=$ & $\begin{array}{l}13,242 \\
23,106 \\
64,188 \\
79,911\end{array}$ & & & & $\begin{array}{l}13,242 \\
23,106 \\
64,679 \\
80,484\end{array}$ \\
\hline & 50 & - & $\begin{array}{r}8,646 \\
29,803\end{array}$ & $\begin{array}{r}8,696 \\
29,803\end{array}$ & - & & & $\begin{array}{r}8,696 \\
29,803\end{array}$ \\
\hline & $\begin{array}{r}4,989 \\
6,674 \\
6,613 \\
4,851 \\
2,000 \\
171 \\
17 \\
- \\
- \\
- \\
- \\
- \\
- \\
-\end{array}$ & $\begin{array}{l}- \\
\overline{-}\end{array}$ & $r=$ & $\begin{array}{r}6,241 \\
14,968 \\
11,802 \\
10,033 \\
10,709 \\
8,040 \\
17,628 \\
15,494 \\
18,227 \\
24,708 \\
26,481 \\
26,518 \\
35,258 \\
31,715 \\
18,819 \\
24,021 \\
31,393 \\
37,369 \\
39,920 \\
52,027\end{array}$ & & $\begin{array}{l}- \\
- \\
- \\
- \\
- \\
-\end{array}$ & $\begin{array}{l}- \\
- \\
- \\
- \\
- \\
- \\
- \\
- \\
- \\
- \\
- \\
- \\
= \\
-\end{array}$ & $\begin{array}{r}6,241 \\
14,968 \\
11,802 \\
10,033 \\
10,709 \\
8,040 \\
17,628 \\
15,494 \\
18,127 \\
24,728 \\
26,481 \\
26,518 \\
35,258 \\
31,715 \\
18,819 \\
24,021 \\
31,393 \\
37,399 \\
39,920 \\
25,027\end{array}$ \\
\hline
\end{tabular}


鋼 材 主 要 製 鐵

(其

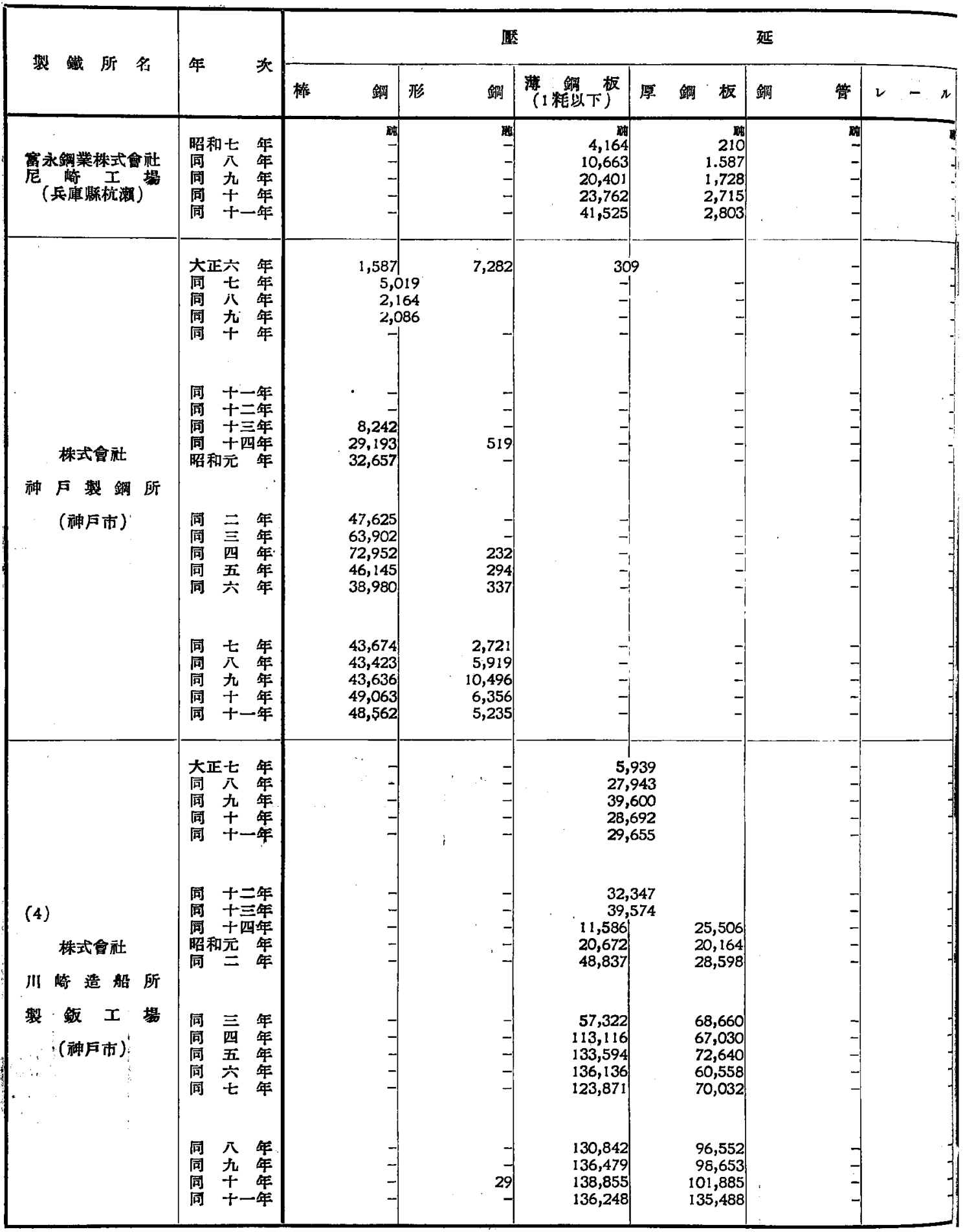

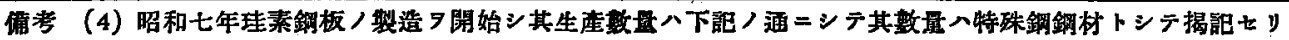

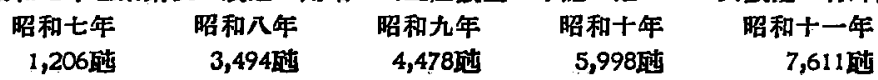


所別生產額 調

十)

\begin{tabular}{|c|c|c|c|c|c|c|c|c|}
\hline 銅 & & 材 & & & & & & \\
\hline 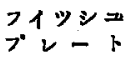 & 材 & ブ & 其 & 計 & 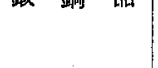 & 踹 & Fos & 口 \\
\hline 政 & 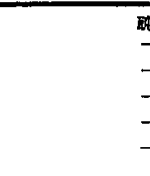 & $\bar{z}$ & - & $\begin{array}{r}\text { 阫 } \\
4,374 \\
18,250 \\
22,129 \\
26,477 \\
44,328\end{array}$ & $=$ & $\begin{array}{l}\bar{y} \\
\bar{z}\end{array}$ & $\begin{array}{l}\text { nt } \\
- \\
- \\
- \\
-\end{array}$ & $\begin{array}{r}4,374 \\
18,750 \\
182,250 \\
22,129 \\
26,477 \\
44,328\end{array}$ \\
\hline & $\begin{array}{r}248 \\
795 \\
2,445 \\
35,472 \\
58,566 \\
\\
75,170 \\
106,056 \\
113,572 \\
176,126 \\
176,752\end{array}$ & $\begin{array}{l}- \\
\overline{-}\end{array}$ & $\begin{array}{r}- \\
- \\
- \\
- \\
146 \\
558 \\
43 \\
\\
3,279 \\
3,560 \\
4,095 \\
1,112 \\
1,062 \\
\\
1,5610 \\
1,805 \\
1,851 \\
2,131 \\
1,653\end{array}$ & $\begin{array}{r}9,178 \\
5,019 \\
2,164 \\
2,086 \\
- \\
- \\
- \\
8,388 \\
30,270 \\
32,700 \\
\\
\\
51,152 \\
68,257 \\
79,724 \\
83,023 \\
98,945 \\
\cdot \\
122,725 \\
157,203 \\
199,555 \\
233,676 \\
232,207\end{array}$ & 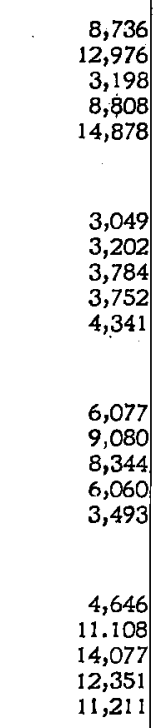 & $\begin{array}{r}3,928 \\
916 \\
3,762 \\
5,973 \\
\\
3,177 \\
3,115 \\
3,258 \\
3,690 \\
4,283 \\
\\
\\
6,320 \\
6,301 \\
5,796 \\
3,468 \\
2,766 \\
\\
\\
4,239 \\
6,330 \\
7,850 \\
12,093 \\
11,094\end{array}$ & $\begin{array}{r}- \\
- \\
- \\
\\
273 \\
482 \\
1,302 \\
1,125 \\
\therefore 818 \\
\\
\\
1,103 \\
1,353 \\
2,291 \\
1,590 \\
880 \\
\\
1,987 \\
3,913 \\
3,495 \\
3,713 \\
2,788\end{array}$ & $\begin{array}{r}17,914 \\
21,923 \\
6,278 \\
14,656 \\
20,851 \\
\\
6,49 \\
6,499 \\
6,799 \\
16,732 \\
38,837 \\
42,142 \\
\\
\\
64,652 \\
844,991 \\
96,155 \\
94,321 \\
106,084 \\
\\
\\
133,597 \\
179,054 \\
224,977 \\
261,833 \\
257,300\end{array}$ \\
\hline & - & $\begin{array}{r}446 \\
2,348\end{array}$ & $\begin{array}{r}3,189 \\
1,390 \\
12,436\end{array}$ & $\begin{array}{r}5,939 \\
27,943 \\
39,600 \\
28,692 \\
29,655 \\
\\
32,447 \\
39,574 \\
37,092 \\
40,836 \\
77,435 \\
\\
\\
125,982 \\
180,146 \\
206,234 \\
196,694 \\
193,903 \\
\\
\\
227,394 \\
238,321 \\
242,605 \\
286,570\end{array}$ & & - & $\begin{array}{r}- \\
\overline{-} \\
- \\
- \\
\overline{-} \\
\overline{-} \\
- \\
- \\
- \\
583 \\
\\
3,494 \\
4,478 \\
6,140 \\
8,328\end{array}$ & $\begin{array}{r}5,939 \\
27,943 \\
39,600 \\
28,6902 \\
29,655 \\
\\
\\
32,347 \\
39,574 \\
37,092 \\
40,836 \\
77,435 \\
\\
\\
125,982 \\
180,146 \\
206,234 \\
196,694 \\
194,486 \\
\\
\\
230,888 \\
242,799 \\
248,745 \\
294,898\end{array}$ \\
\hline
\end{tabular}


鋼材主要製鐵

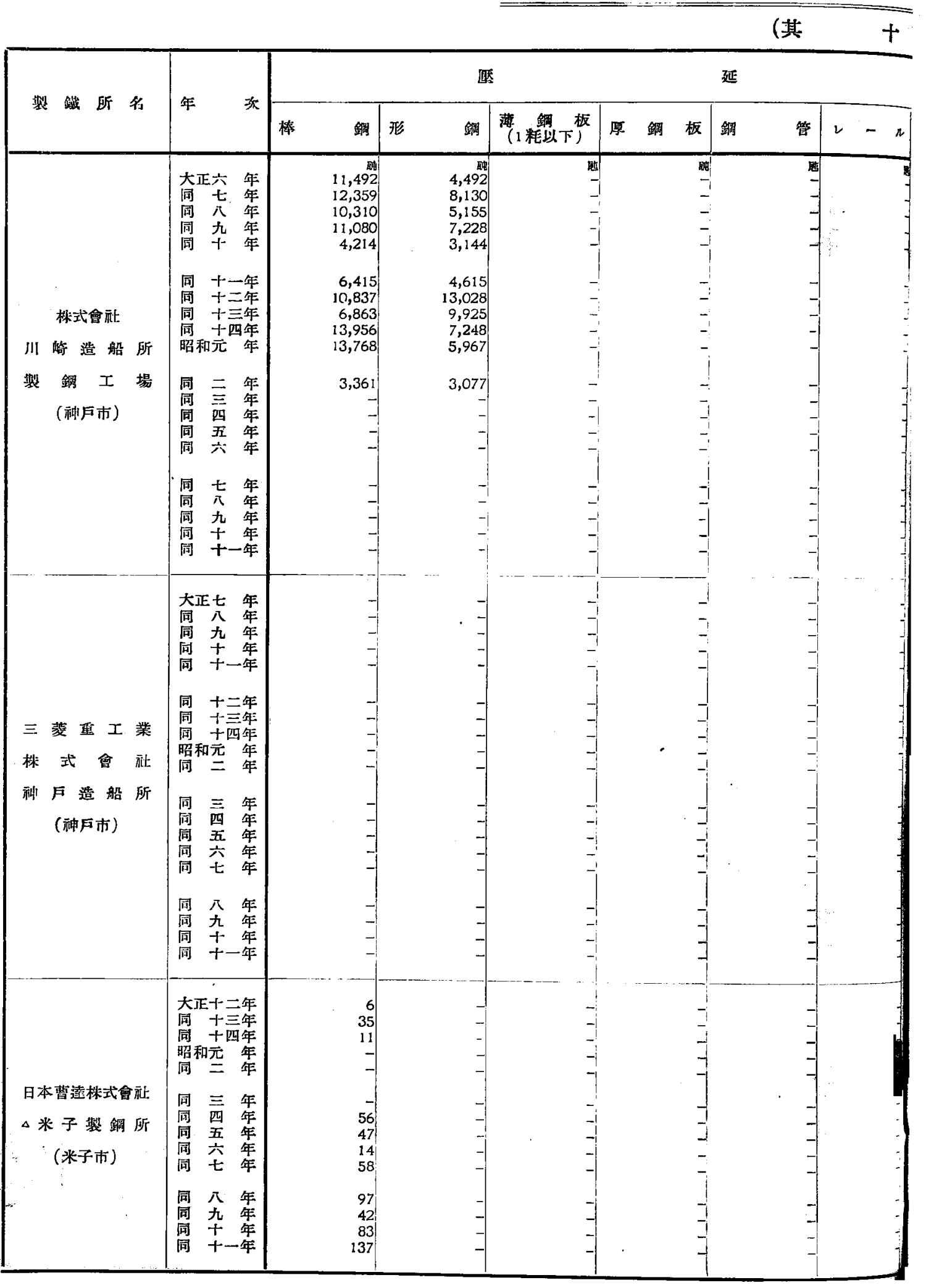




\section{所別生產額調}

-)

\begin{tabular}{|c|c|c|c|c|c|c|c|c|c|}
\hline 銅 & & 材 & & & & & & & \\
\hline $\begin{array}{l}\text { フィッシニ } \\
\text { プレート }\end{array}$ & 線材 & $7 y \neq$ & 其 & 就 & & & & & \\
\hline $\begin{array}{l}\text { 啿 } \\
- \\
- \\
- \\
- \\
- \\
- \\
- \\
- \\
-\end{array}$ & $\begin{array}{l}\text { 매 } \\
- \\
- \\
- \\
- \\
- \\
- \\
- \\
- \\
- \\
- \\
- \\
- \\
- \\
- \\
- \\
- \\
- \\
- \\
- \\
-\end{array}$ & & - & $\begin{array}{r}15,984 \\
20,489 \\
15,465 \\
18,308 \\
7,358 \\
\\
11,030 \\
23,865 \\
16,788 \\
21,204 \\
19,735 \\
6,438 \\
- \\
- \\
- \\
- \\
- \\
- \\
7,542\end{array}$ & $\begin{array}{r}\text { mo } \\
50 \\
1,961 \\
4,010 \\
3,439 \\
2,242 \\
\\
1,862 \\
2,504 \\
2,750 \\
2,322 \\
2,860 \\
\\
- \\
2,481 \\
2,769 \\
1,936 \\
999 \\
\\
1,785 \\
3,500 \\
4,255 \\
4,609 \\
4,290\end{array}$ & $\begin{array}{r}2,706 \\
2,964 \\
3,642 \\
7,230 \\
\\
4,256 \\
7,696 \\
3,080 \\
5,596 \\
7,002 \\
\\
3,621 \\
3,498 \\
3,133 \\
3,626 \\
1,791 \\
\\
1,182 \\
2,843 \\
3,833 \\
4,670 \\
4,194 !\end{array}$ & $\begin{array}{r}\text { 데 } \\
- \\
- \\
- \\
- \\
40 \\
37 \\
186 \\
274 \\
150 \\
- \\
169 \\
91 \\
111 \\
\\
286 \\
31 \\
49 \\
667 \\
583\end{array}$ & 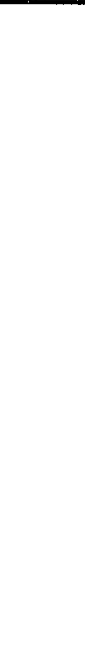 & $\begin{array}{r}18,740 \\
22,450 \\
22,439 \\
25,389 \\
16,830 \\
\\
17,148 \\
34,105 \\
22,655 \\
29,308 \\
29,871 \\
10,209 \\
5,979 \\
6,071 \\
5,653 \\
2,901 \\
\\
3,253 \\
6,374 \\
8,137 \\
9,946 \\
16,609\end{array}$ \\
\hline $\begin{array}{l}- \\
- \\
-\end{array}$ & $\begin{array}{l}- \\
- \\
-1 \\
-1 \\
-1 \\
- \\
- \\
- \\
- \\
- \\
- \\
- \\
- \\
- \\
- \\
-\end{array}$ & & $\begin{array}{l}- \\
- \\
- \\
- \\
- \\
- \\
- \\
-\end{array}$ & $\begin{array}{l}- \\
- \\
- \\
- \\
- \\
- \\
- \\
- \\
- \\
- \\
- \\
- \\
- \\
- \\
-\end{array}$ & $\begin{array}{r}943 \\
839 \\
978 \\
1,345 \\
1,378 \\
\\
632 \\
565 \\
615 \\
686 \\
701 \\
\\
894 \\
836 \\
564 \\
615 \\
806 \\
\\
960 \\
1,092 \\
1,096 \\
1,120 \\
\end{array}$ & $\begin{array}{r}582 \\
527 \\
375 \\
709 \\
1,341 \\
407 \\
367 \\
283 \\
245 \\
376 \\
202 \\
162 \\
5 \\
- \\
- \\
- \\
9 \\
460\end{array}$ & $\begin{array}{r}86 \\
- \\
- \\
- \\
- \\
- \\
- \\
30 \\
- \\
- \\
64 \\
67 \\
56 \\
88 \\
191 \\
145 \\
130 \\
193\end{array}$ & $\therefore i$ & $\begin{array}{r}1,611 \\
1,366 \\
1,353 \\
2.054 \\
2,719 \\
\\
1,039 \\
932 \\
898 \\
961 \\
1,077 \\
1,096 \\
1,062 \\
636 \\
671 \\
894 \\
\\
1,151 \\
1,237 \\
1,325 \\
1,773\end{array}$ \\
\hline & $\begin{array}{l}-1 \\
- \\
- \\
- \\
- \\
- \\
- \\
- \\
- \\
-\end{array}$ & & $\begin{array}{l}- \\
- \\
-\end{array}$ & $\begin{array}{r}6 \\
35 \\
11 \\
- \\
- \\
- \\
56 \\
47 \\
14 \\
58 \\
97 \\
42 \\
83 \\
137\end{array}$ & $\begin{array}{r}14 \\
9 \\
10 \\
12 \\
28 \\
48 \\
- \\
- \\
85 \\
75 \\
35 \\
12 \\
2\end{array}$ & $\begin{array}{l}256 \\
383 \\
655 \\
498 \\
492 \\
430 \\
375 \\
458 \\
472 \\
359 \\
455 \\
483 \\
531 \\
605\end{array}$ & $\begin{array}{r}161 \\
133 \\
116 \\
76 \\
85 \\
\\
129 \\
158 \\
80 \\
114 \\
193 \\
\\
: \quad 278 \\
376 \\
\quad 370 \\
: \quad 85\end{array}$ & & $\begin{array}{l}437 \\
560 \\
792 \\
586 \\
605 \\
607 \\
589 \\
585 \\
685 \\
685 \\
865 \\
913 \\
986 \\
828\end{array}$ \\
\hline
\end{tabular}


鋼 材主 要製 鐵

（其

$+$

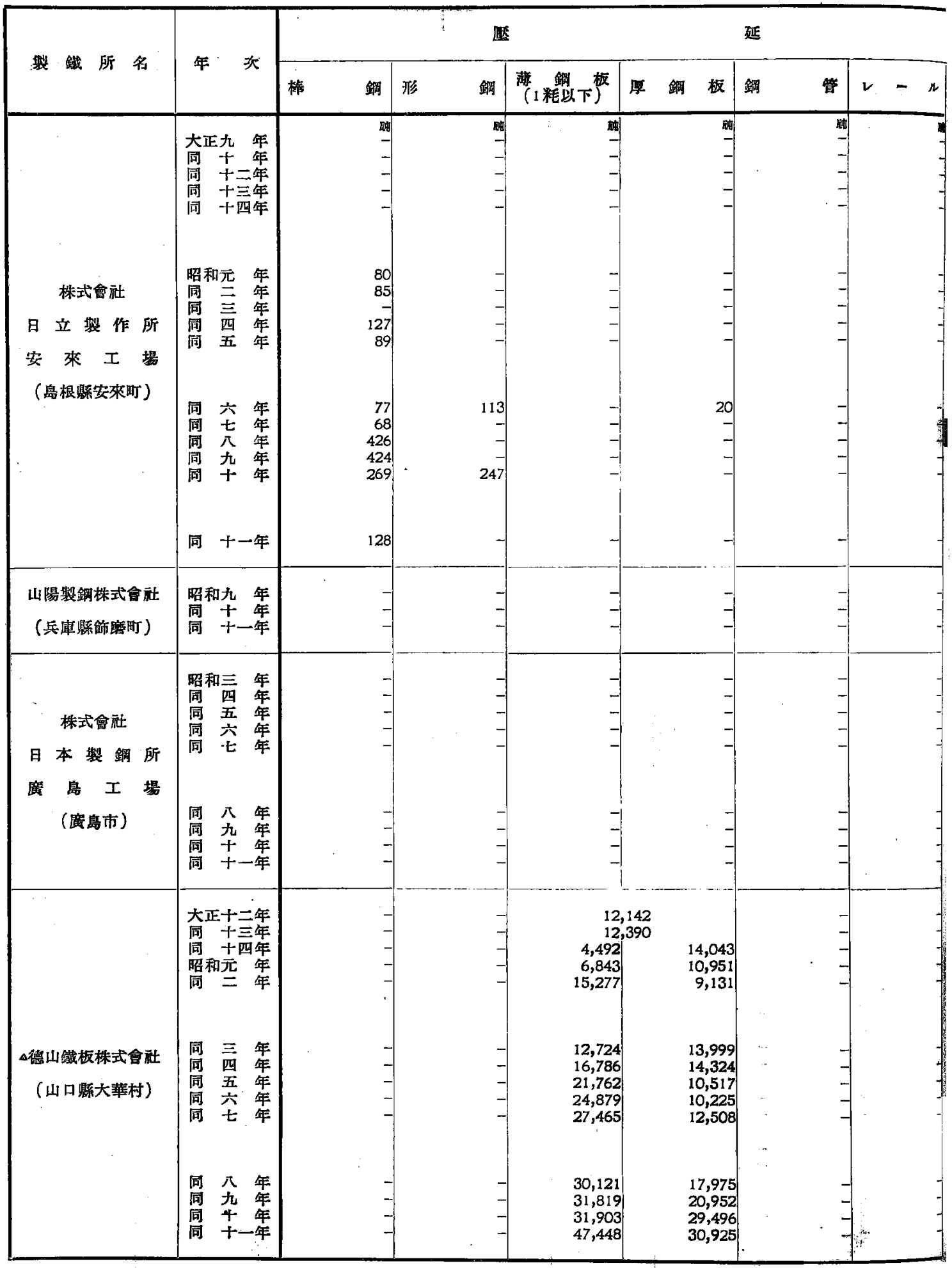


所別生產額 調

二)

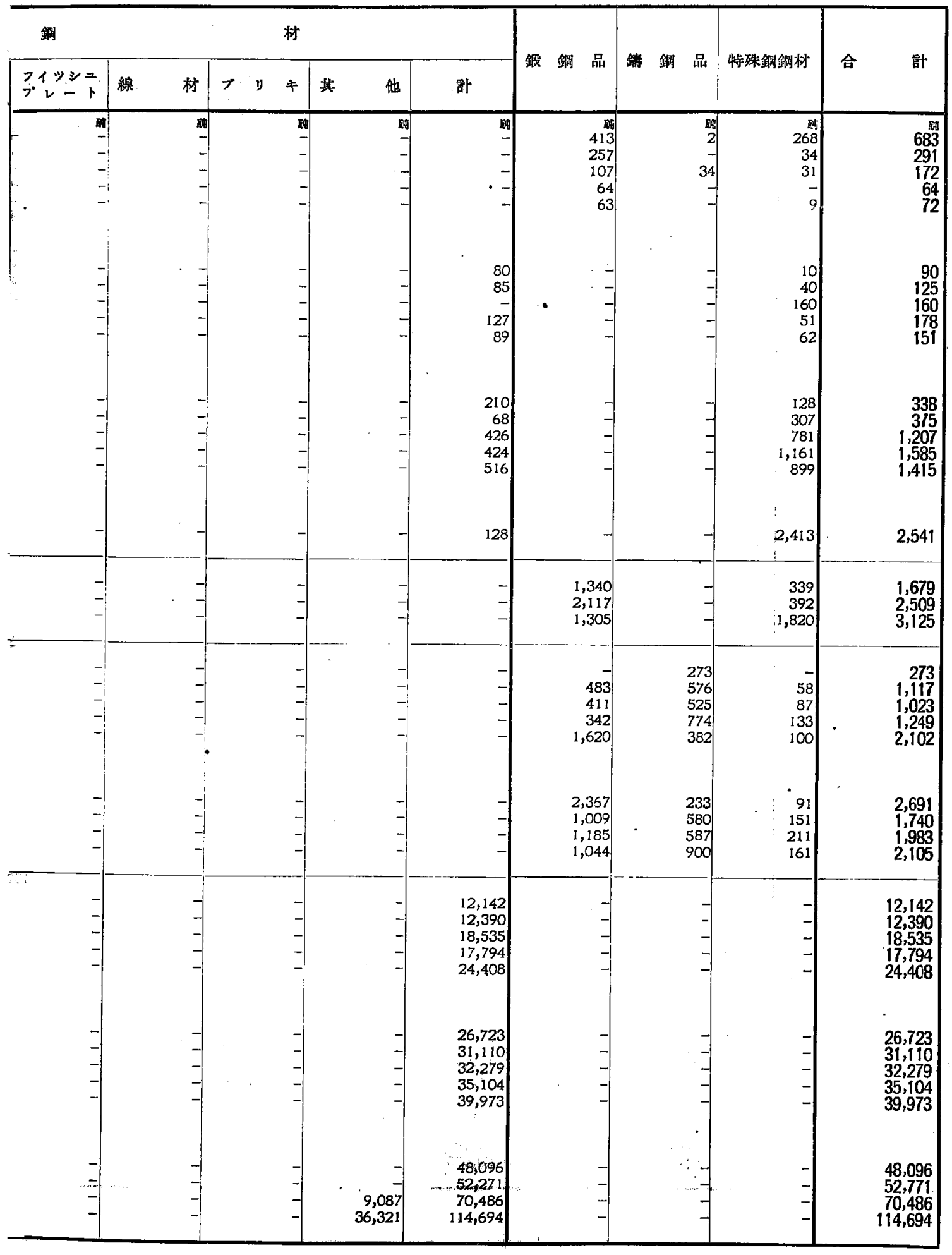


鋼材主要製鐵

(其

$+$

\begin{tabular}{|c|c|c|c|c|c|c|c|c|c|}
\hline \multirow{2}{*}{ 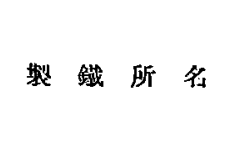 } & \multirow{2}{*}{ 年 灾 } & \multicolumn{5}{|c|}{ 硻 } & 延 & \\
\hline & & 銅 & 形 & 䔳 & 厚 & 鋼 板 & 銅 & 管 & $2-n$ \\
\hline $\begin{array}{l}\text { 小倉裴銅楼式會社 } \\
\text { (小會市) }\end{array}$ & 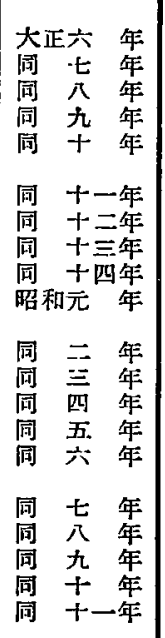 & 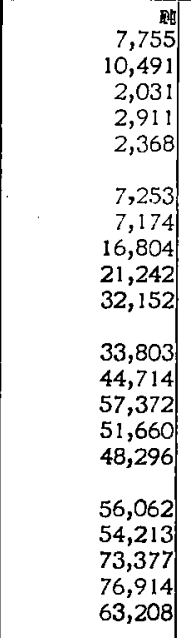 & $\begin{array}{r}7 \\
- \\
- \\
- \\
- \\
- \\
-\end{array}$ & $\begin{array}{l}\text { 明 } \\
= \\
- \\
- \\
- \\
= \\
= \\
- \\
- \\
= \\
= \\
- \\
= \\
-\end{array}$ & & $\begin{array}{l}\text { 明 } \\
- \\
= \\
= \\
- \\
- \\
= \\
= \\
-\end{array}$ & & $\begin{array}{l}\text { 明 } \\
= \\
- \\
- \\
= \\
= \\
= \\
- \\
=\end{array}$ & \\
\hline 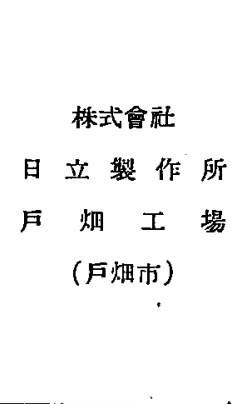 & 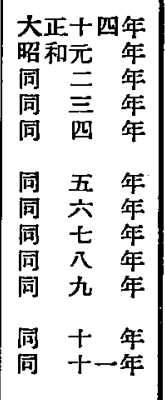 & $\begin{array}{l}- \\
- \\
-\end{array}$ & $\begin{array}{l}\bar{y} \\
\bar{y}\end{array}$ & $\begin{array}{l}- \\
- \\
- \\
- \\
-1 \\
-1 \\
-1 \\
-1\end{array}$ & & - & & $=$ & \\
\hline 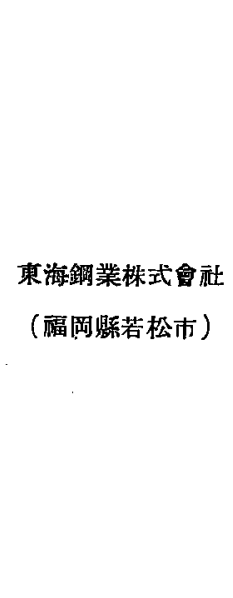 & 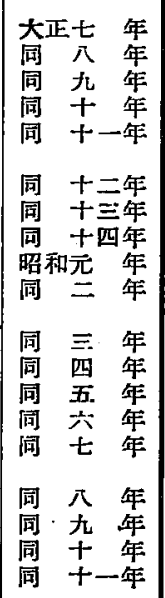 & $\begin{array}{r}69 \\
2,798 \\
1,433 \\
2,020 \\
2,487 \\
2,000 \\
721 \\
166 \\
320 \\
- \\
- \\
- \\
- \\
868 \\
- \\
-\end{array}$ & $\begin{array}{r}- \\
- \\
1,029 \\
8,614 \\
14,365 \\
15,715 \\
20,114 \\
20,252 \\
21,064 \\
29,464 \\
25,438 \\
20,974 \\
13,840 \\
21,043 \\
25,492 \\
30,871 \\
31,499 \\
38,575\end{array}$ & $\begin{array}{r}9, \\
12, \\
= \\
=\end{array}$ & $\begin{array}{l}195 \\
203 \\
186 \\
294 \\
537 \\
702 \\
461\end{array}$ & $\begin{array}{l}14,106 \\
16,717 \\
17,866 \\
19,419 \\
24,426 \\
13,569 \\
13,385 \\
21,857 \\
26,898 \\
36,328 \\
34,784 \\
34,454\end{array}$ & & 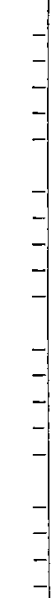 & $\begin{array}{l}3399 \\
990 \\
845\end{array}$ \\
\hline
\end{tabular}


所別生產 額 調

三)

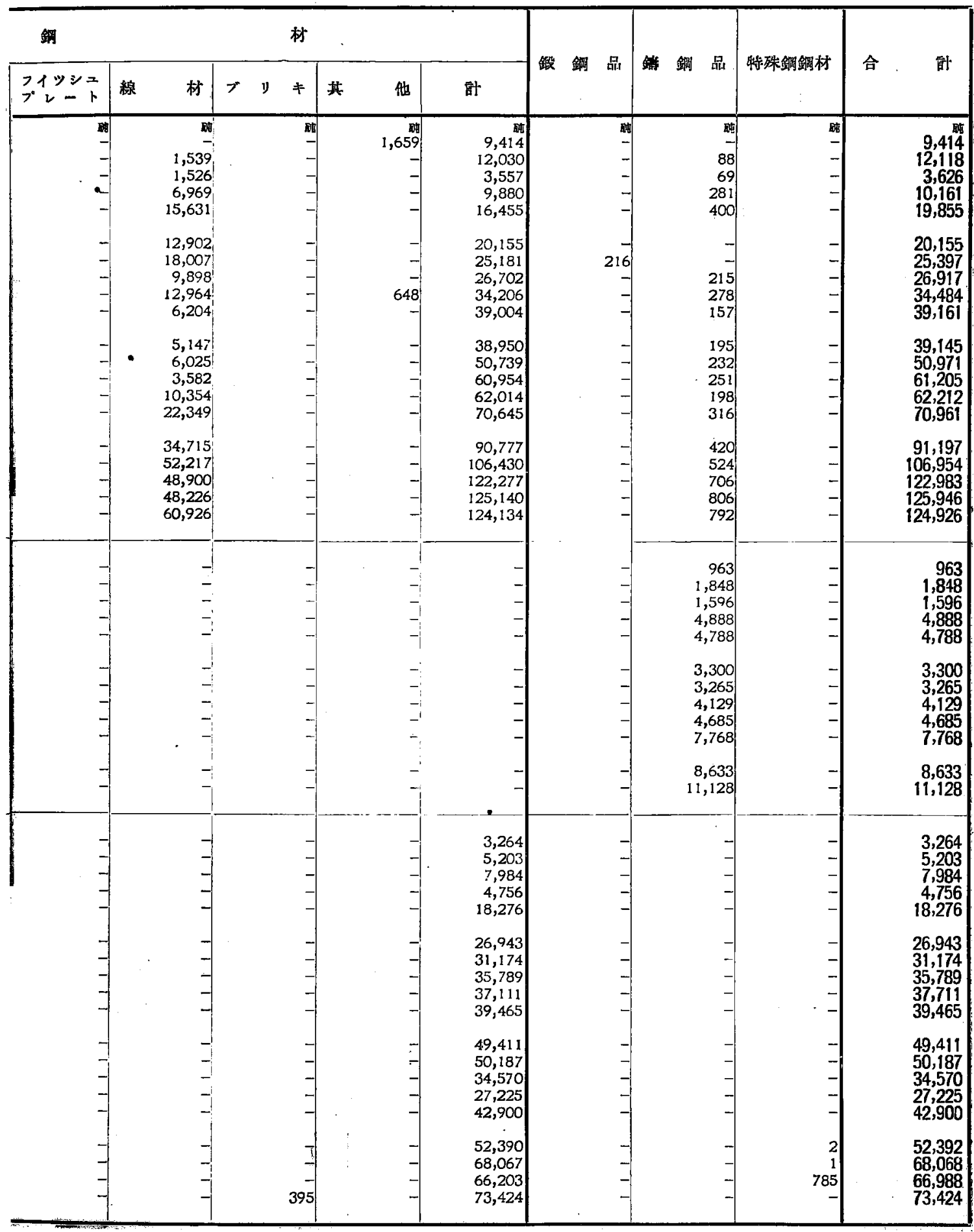


鋼材圭要製鐵

(其

$+$

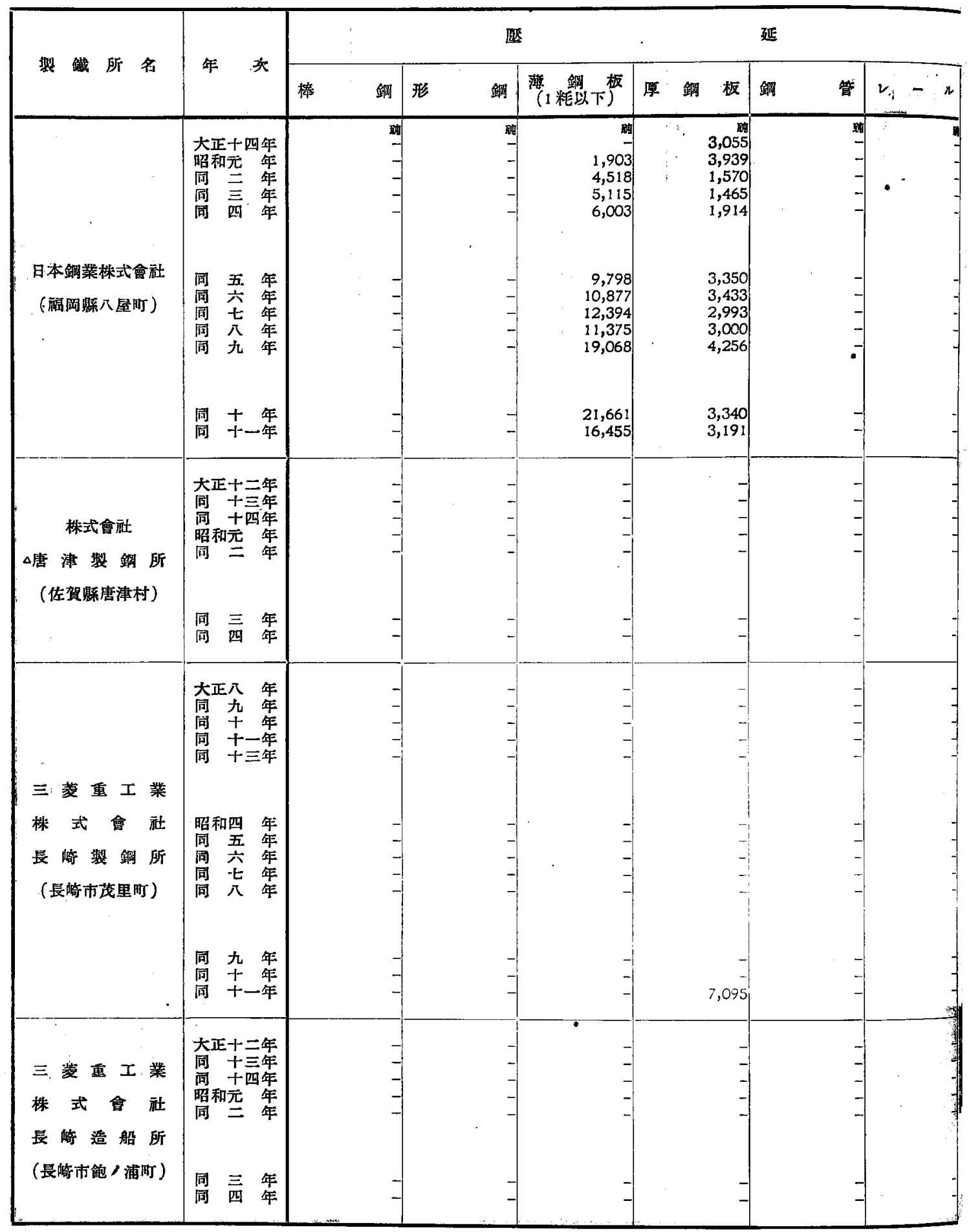

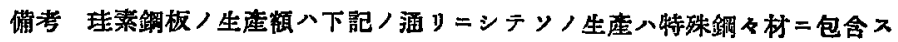

昭和十一年 49 聉 
所別生產額調

四）

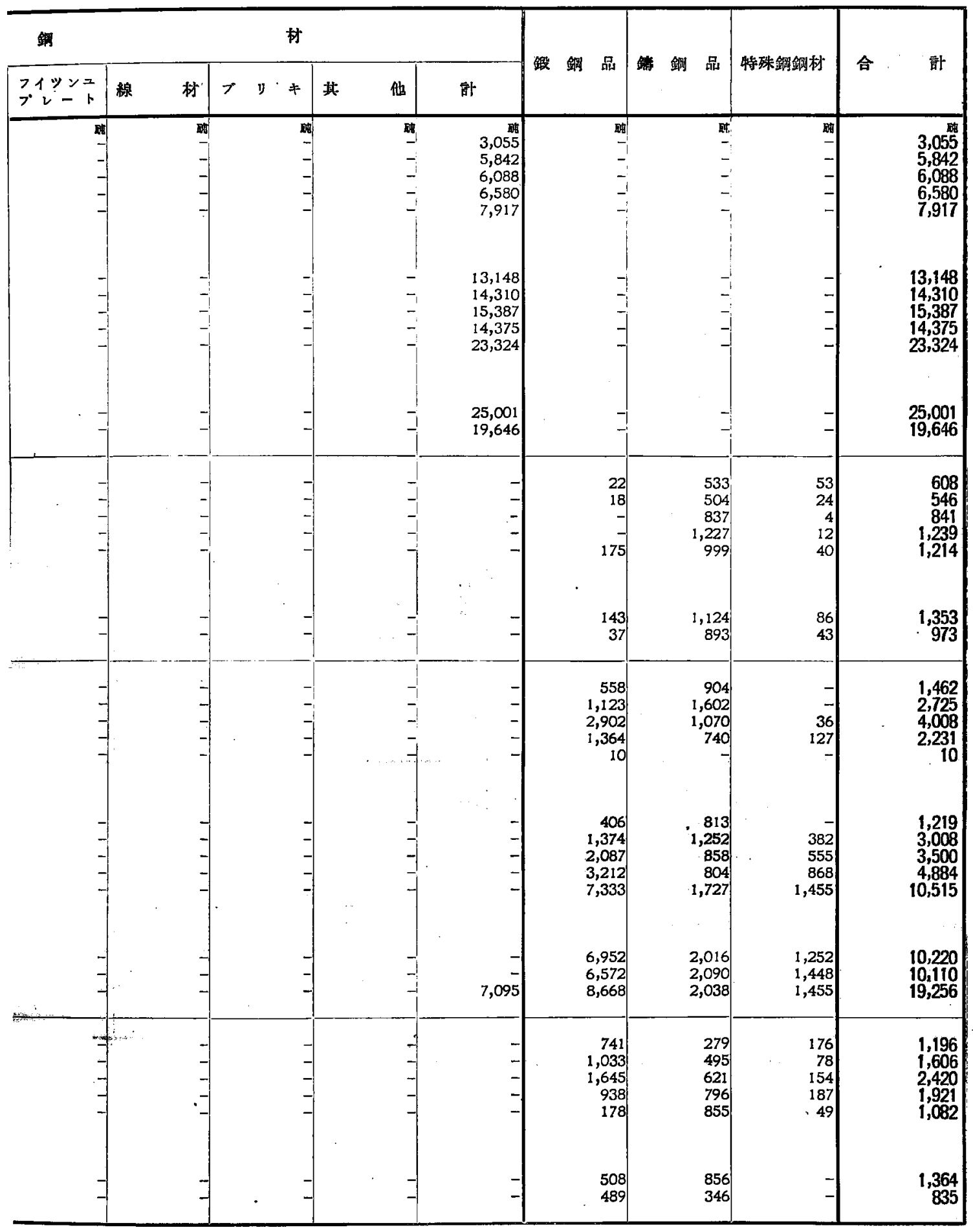


鋼 材主要製 鐵

（其

$+$

\begin{tabular}{|c|c|c|c|c|c|c|c|c|c|c|}
\hline \multirow{2}{*}{ 制 所 和 } & \multirow{2}{*}{ 年 次 } & \multicolumn{4}{|c|}{ 最 } & \multicolumn{3}{|c|}{ 延 } & & \multirow[b]{2}{*}{$-n$} \\
\hline & & 棒 & 形 & 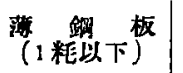 & 厚 & 銿 板 & 銅 & 管 & 2 & \\
\hline 其 他 製 所 & 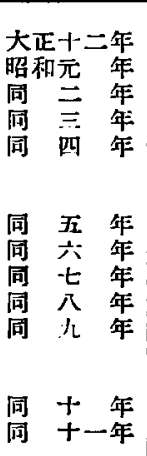 & $\begin{array}{r}r \\
- \\
- \\
- \\
68,350 \\
\\
33,296 \\
77,521 \\
97,510 \\
148,431 \\
128,689 \\
\\
171,213 \\
154,158\end{array}$ & $\begin{array}{r}\text { 吡 } \\
- \\
- \\
- \\
\\
\\
623 \\
2,738 \\
1,930 \\
3,500 \\
2,310 \\
\\
6,619 \\
9,059\end{array}$ & $\begin{array}{l}\text { 球 } \\
- \\
- \\
- \\
- \\
- \\
- \\
- \\
- \\
-\end{array}$ & ; & $\begin{array}{r}r \\
- \\
- \\
- \\
1,142 \\
1,121 \\
1,348 \\
- \\
5,278\end{array}$ & & $\begin{array}{l}\text { 暗 } \\
-1 \\
- \\
- \\
- \\
- \\
- \\
- \\
- \\
- \\
- \\
- \\
- \\
-\end{array}$ & & - \\
\hline & $\begin{array}{l}\text { 犬正十三年 } \\
\text { 同 十三年 } \\
\text { 同 十四年 } \\
\text { 昭和元 年 } \\
\text { 同 二 年 }\end{array}$ & $\begin{array}{l}209,139 \\
276,284 \\
344,632 \\
427,484 \\
460,484\end{array}$ & $\begin{array}{l}121,619 \\
138,141 \\
137,512 \\
169,577 \\
208,001\end{array}$ & $\begin{array}{r}174, \\
188, \\
28,295 \\
44,489 \\
87,867\end{array}$ & $\begin{array}{l}228 \\
821\end{array}$ & $\begin{array}{l}207,262 \\
235,868 \\
246,887\end{array}$ & & $\begin{array}{l}28,046 \\
34,593 \\
36,240 \\
42,509 \\
50,491\end{array}$ & & $\begin{array}{r}92,927 \\
77,880 \\
131,972 \\
166,597 \\
169,03 \text { \% }\end{array}$ \\
\hline 合 & 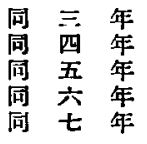 & $\begin{array}{l}552,107 \\
683,841 \\
483,555 \\
467,333 \\
568,446\end{array}$ & $\begin{array}{l}253,227 \\
255,553 \\
250,753 \\
202,508 \\
252,402\end{array}$ & $\begin{array}{l}101,267 \\
174,469 \\
214,411 \\
252,116 \\
257,265\end{array}$ & & $\begin{array}{l}317,072 \\
531,610 \\
333,761 \\
280,442 \\
316,262\end{array}$ & & $\begin{array}{l}64,460 \\
78,492 \\
88,336 \\
63,491 \\
95,890\end{array}$ & & $\begin{array}{l}199,25 \\
259,35 \\
278,00 \\
102,84 \\
226,74\end{array}$ \\
\hline$\cdot$ & 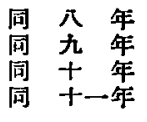 & $\begin{array}{r}773,829 \\
778,451 \\
1,015,744 \\
1,027,318\end{array}$ & $\begin{array}{l}331,439 \\
430,321 \\
467,836 \\
554,815\end{array}$ & $\begin{array}{l}271,416 \\
324,746 \\
389,340 \\
520,314\end{array}$ & & $\begin{array}{l}475,722 \\
602,864 \\
712,909 \\
877,567\end{array}$ & & $\begin{array}{l}117,287 \\
136,969 \\
166,682 \\
188,659\end{array}$ & & $\begin{array}{l}258,08 \\
347,3 f_{1} \\
348,864 \\
278,78\end{array}$ \\
\hline 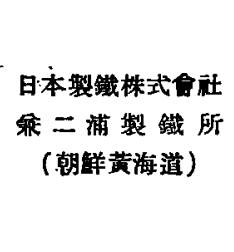 & $\begin{array}{l}\text { 大正八 年 } \\
\text { 同 九 年 } \\
\text { 同 十 年 } \\
\text { 同十一年 } \\
\text { 昭和九 年 } \\
\text { 同 + 年 } \\
\text { 同 +一年 }\end{array}$ & $\begin{array}{r}1,362 \\
21,817 \\
27,714 \\
7,053 \\
-\end{array}$ & $\begin{array}{r}3,222 \\
3,628 \\
- \\
- \\
\\
13,603 \\
17,634\end{array}$ & $\begin{array}{l}- \\
- \\
- \\
-\end{array}$ & & $\begin{array}{r}- \\
- \\
2,312 \\
2,359 \\
21,619 \\
\\
38,229 \\
38,978\end{array}$ & & $\begin{array}{l}- \\
- \\
- \\
- \\
- \\
- \\
- \\
-\end{array}$ & & \\
\hline 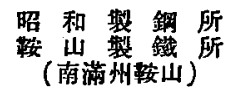 & $\begin{array}{l}\text { 照和十 年 } \\
\text { 同 十一年 }\end{array}$ & $\begin{array}{l}12,346 \\
67,287\end{array}$ & - & $\begin{array}{r}4,704 \\
29,141\end{array}$ & & 498 & & - & & $\begin{array}{r}8,397 \\
39,22\end{array}$ \\
\hline
\end{tabular}

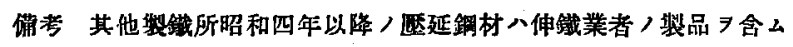




\section{所別生產 額 調}

五)

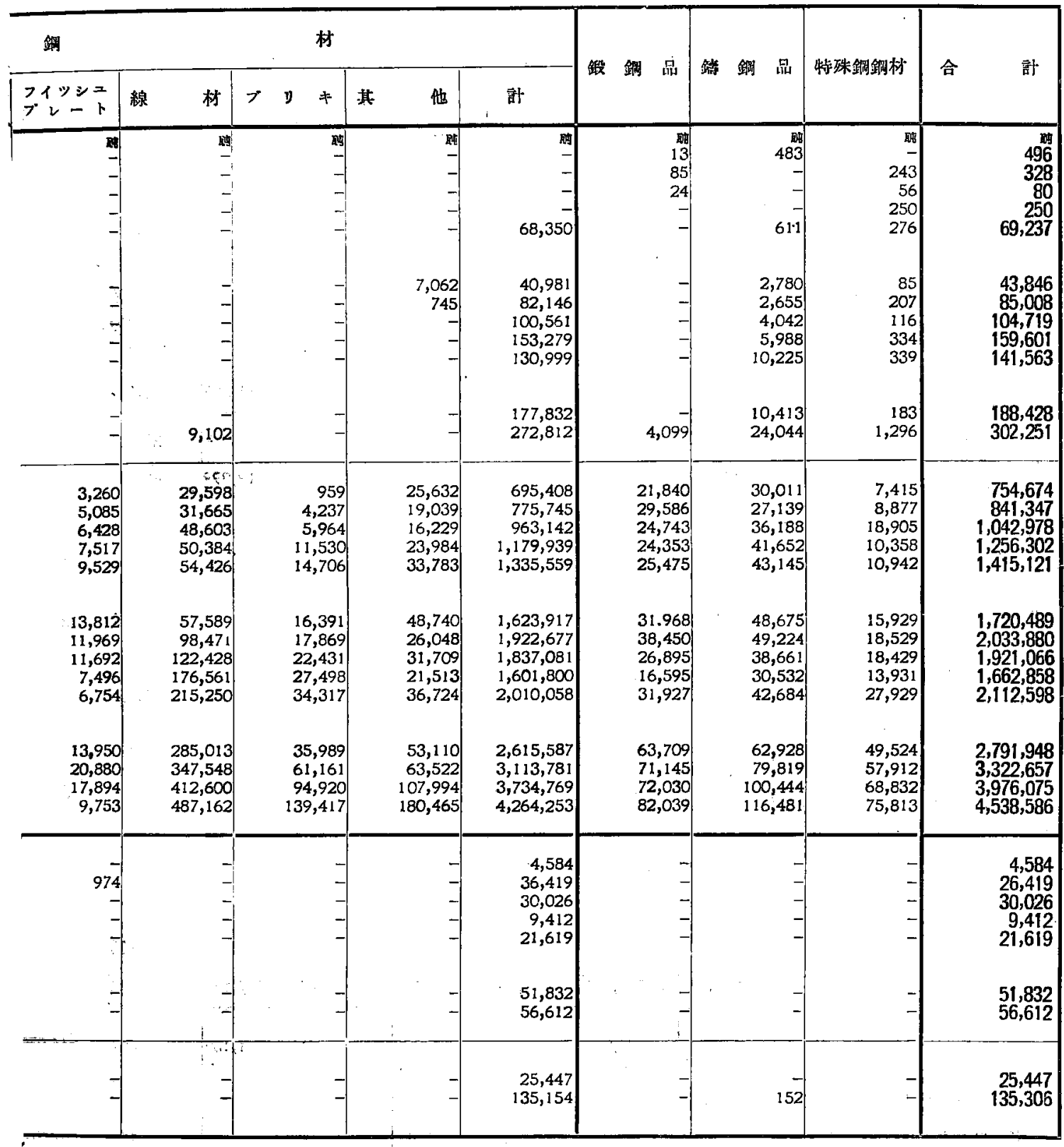


本邦鐵鐄及鐵銅

(其

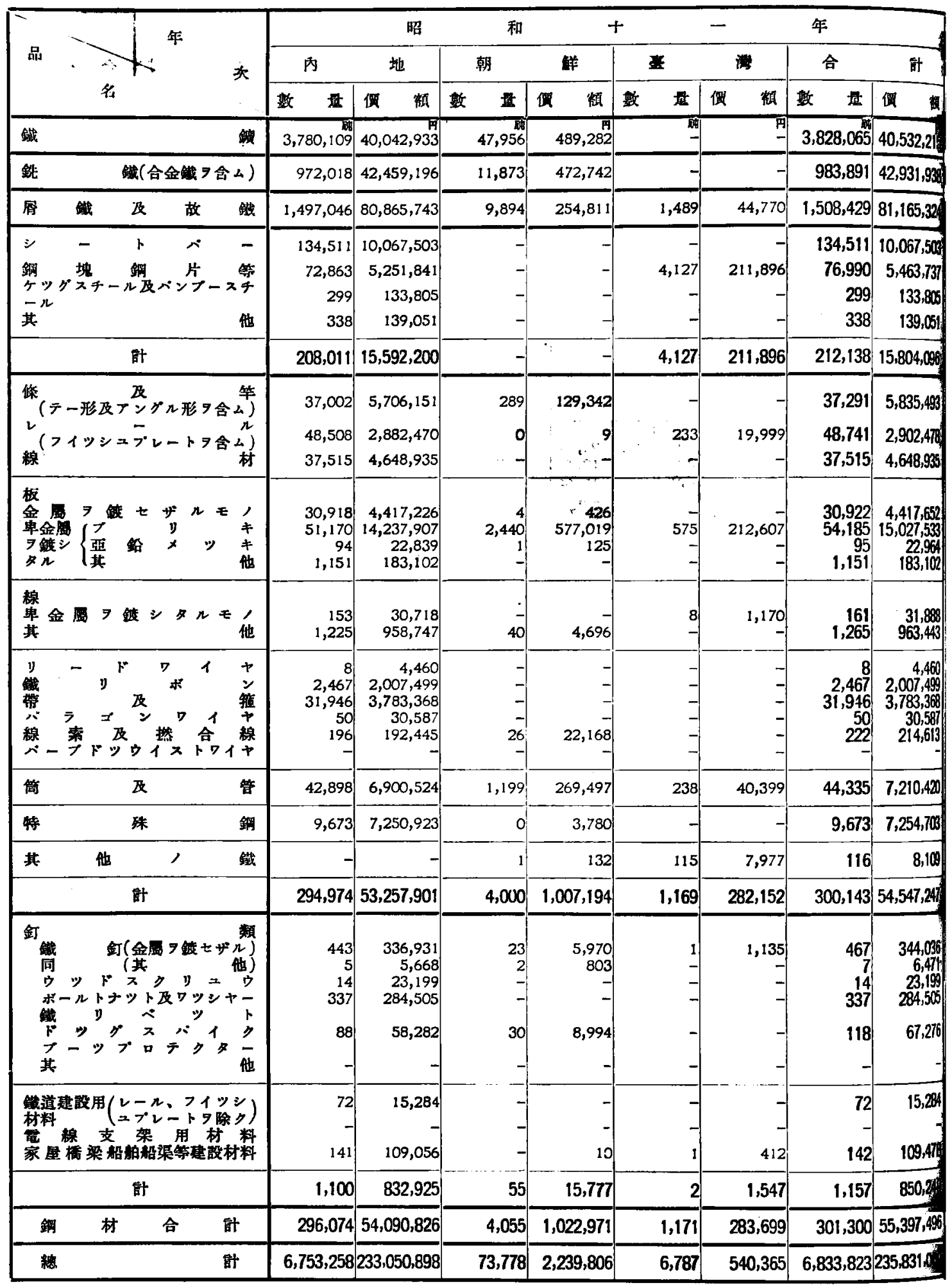




\section{材品種別輸入表}

-)

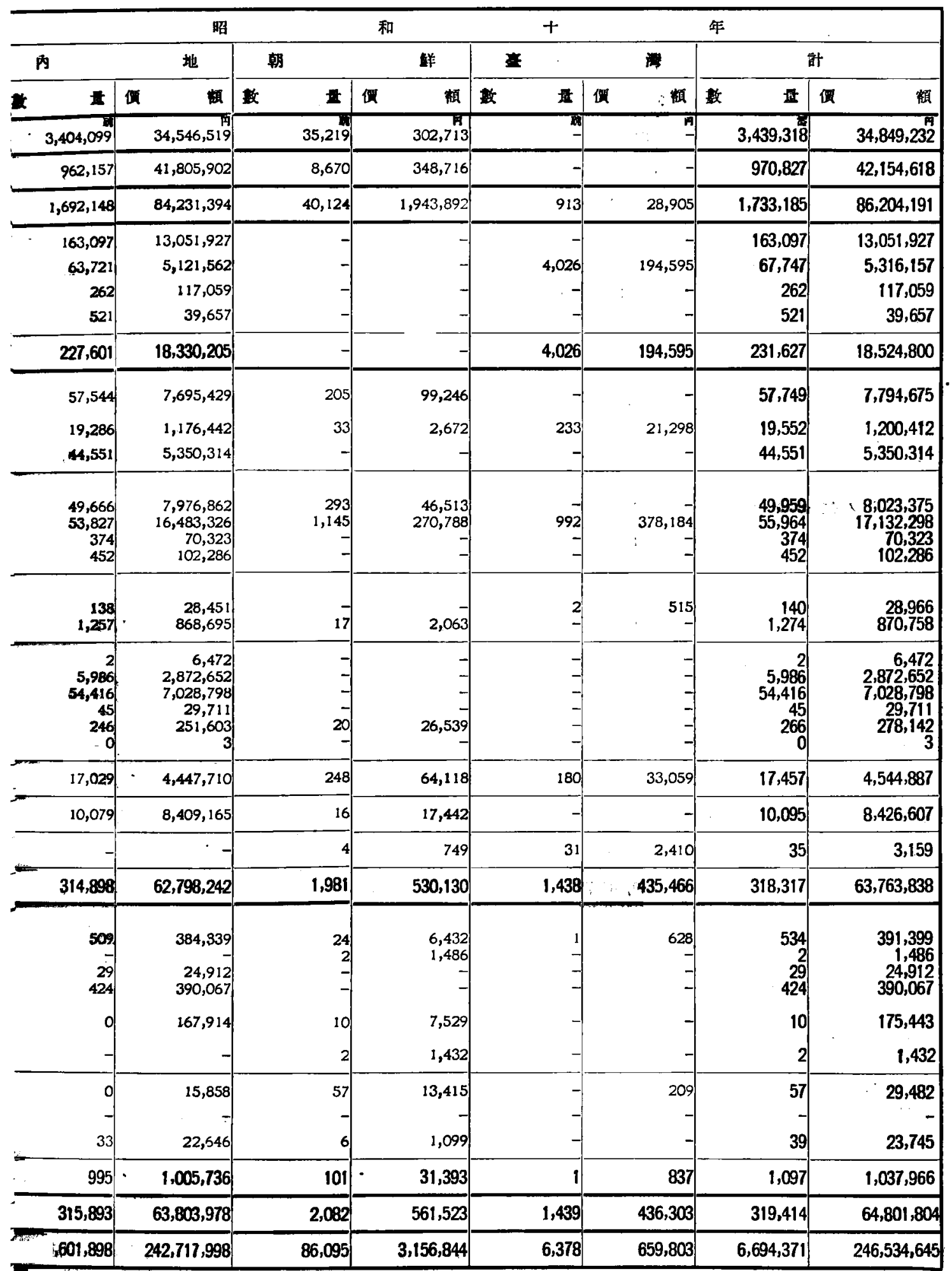


本邦鐵鐄及鐵銅

（其

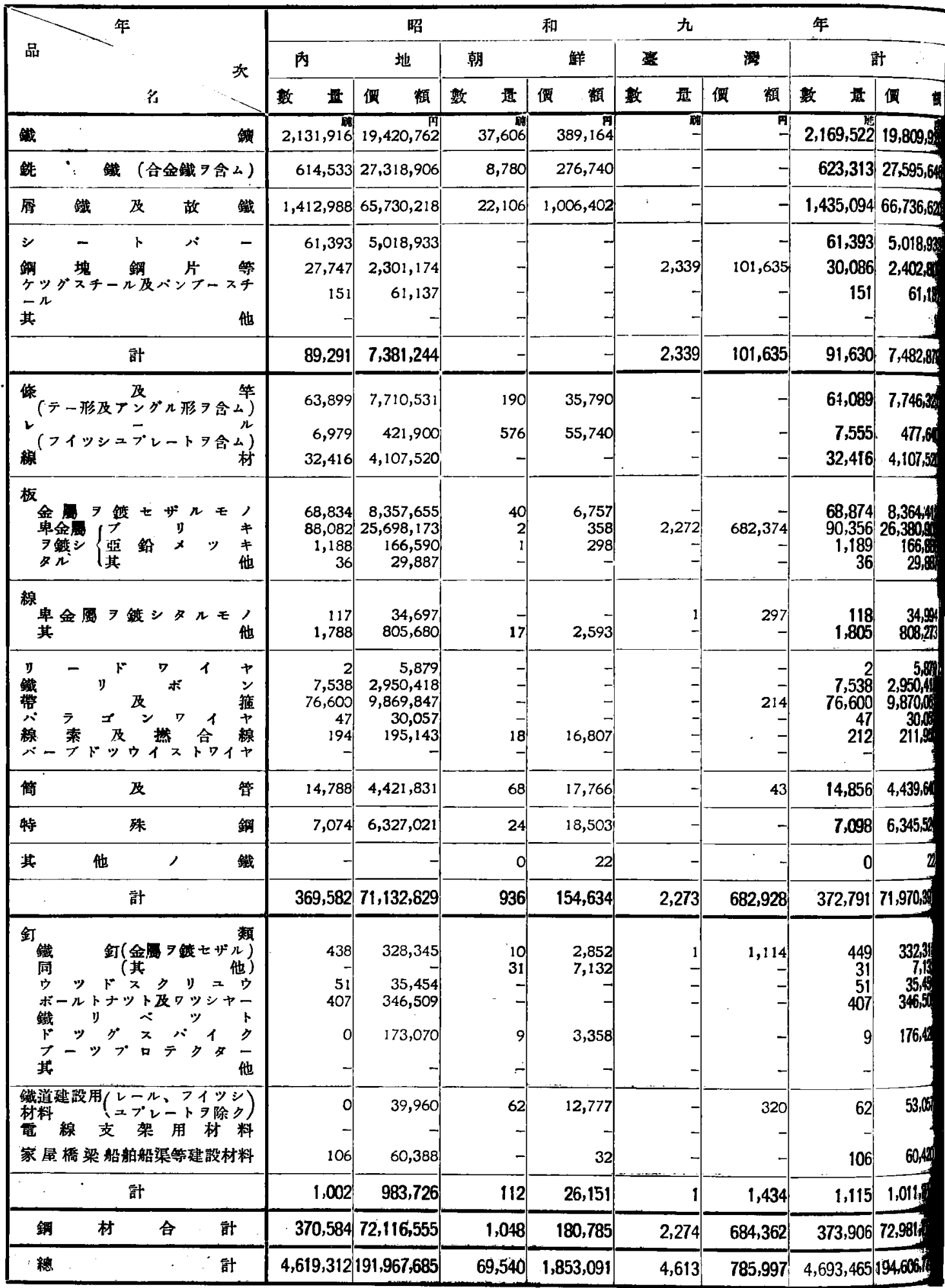




\section{材品種別輸入表}

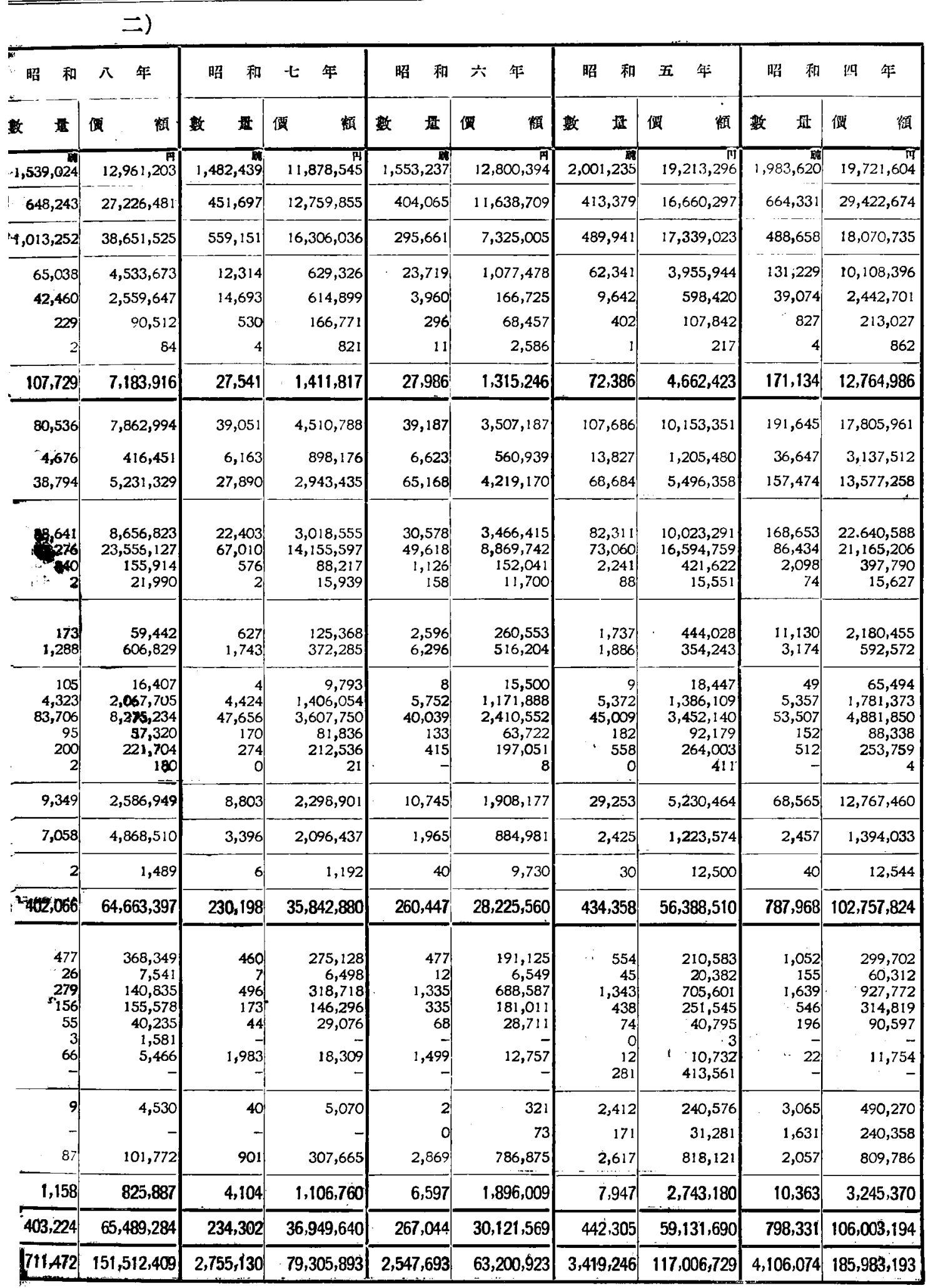




\section{本邦鐵䥄及鐵鋼材品種別輸入表}

（其 三)

\begin{tabular}{|c|c|c|c|c|c|c|}
\hline 年 & 和 & 年 & 昭 & 年 & 昭 & 元 \\
\hline 名。 & 垬 & 顧 & 數 遮 & 額 & 數 & 促 \\
\hline 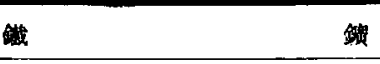 & $1,659,948$ & $16,604,166$ & 951,966 & $9,257,664$ & 810,705 & $7,389,09$ \\
\hline 践(合全鐵 7 含 4 ) & 579,640 & $26,380,192$ & 485,124 & $22,308,151$ & 409,287 & $18,787,880$ \\
\hline 届 故 鐵 & 364,309 & $13,378,202$ & 225,031 & $8,305,317$ & 80,454 & 2,928 \\
\hline - $1 \quad ハ$ sir & 73,401 & $5,750,196$ & 55,463 & $3,818,239$ & - & \\
\hline 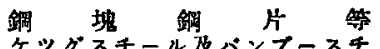 & 18,056 & $1,245,133$ & 34,548 & $2,171,661$ & 11,693 & 695,852 \\
\hline 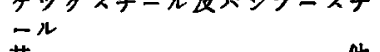 & 680 & 220,534 & 404 & 102,738 & & \\
\hline & 131 & 18,381 & - & - & 24,100 & $1,646,219$ \\
\hline 郭 & 92,268 & $7,234,244$ & 90,415 & $6,092,638$ & 35,793 & $2,342,071$ \\
\hline 倈 & 142,547 & $12,734,162$ & 206,884 & $13,691,515$ & 278,816 & 22,22 \\
\hline レ(フイッシニデレートヨ念ム) & 50,425 & $4,252,726$ & 94,424 & $7,419,176$ & 101,687 & $7,762,2^{3}$ \\
\hline 線材 & 172,643 & $13,378,746$ & 109,090 & $8,297,638$ & 117,971 & $9,325,8$ \\
\hline 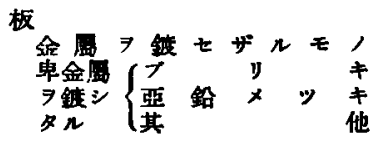 & $\begin{array}{r}270,926 \\
75,001 \\
1,782 \\
6\end{array}$ & $\begin{array}{r}38,724,633 \\
17,493,672 \\
361,812 \\
4,881\end{array}$ & $\begin{array}{r}240,373 \\
63,446 \\
1,523 \\
30\end{array}$ & $\begin{array}{r}35,879,930 \\
15,758,448 \\
318,822 \\
14,003\end{array}$ & $\begin{array}{r}260,904 \\
52,402 \\
995 \\
181\end{array}$ & $\begin{array}{r}40,780,24 \\
12,294, \\
193,2 \\
44,5\end{array}$ \\
\hline 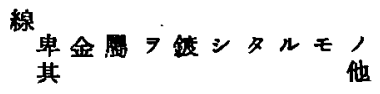 & $\begin{array}{l}7,018 \\
2,447\end{array}$ & $\begin{array}{r}1,493,280 \\
482,222\end{array}$ & $\begin{array}{r}10,714 \\
1,337\end{array}$ & $\begin{array}{r}1,852,832 \\
322,103\end{array}$ & $\begin{array}{r}35,232 \\
1,413\end{array}$ & $\begin{aligned} 5,455, \\
308,\end{aligned}$ \\
\hline 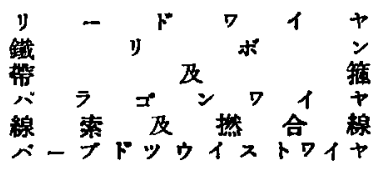 & $\begin{array}{r}127 \\
4,771 \\
30,232 \\
\because \quad 196 \\
\hdashline \quad 628 \\
\hdashline \quad 457\end{array}$ & $\begin{array}{r}80,353 \\
1,538,372 \\
2,486,433 \\
124,175 \\
312,533 \\
19,772\end{array}$ & $\begin{array}{r}50 \\
3,329 \\
14,843 \\
167 \\
503 \\
1,945\end{array}$ & $\begin{array}{r}66,922 \\
1,153,736 \\
1,304,901 \\
111,887 \\
274,449 \\
58,554\end{array}$ & $\begin{array}{r}2,67 \overline{1} \\
15,052 \\
501\end{array}$ & $\begin{array}{r}1,036,654 \\
1,750,674 \\
269,518\end{array}$ \\
\hline 及 & 58,677 & $10,224,050$ & 57,322 & $9,747,613$ & 51,999 & 9,890 \\
\hline 特 & 2,790 & $1,517,855$ & 2,578 & $1,302,260$ & - & \\
\hline 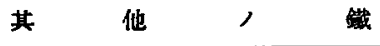 & 13 & 7,760 & 111 & 19,336 & 1,281 & 247,28 \\
\hline 計 & 820,686 & $105,237,442$ & 808,369 & $97,594,125$ & 921,105 & $112,278,50^{\circ}$ \\
\hline 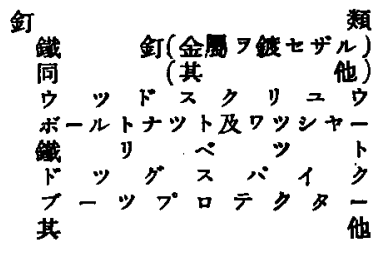 & $\begin{array}{r}788 \\
186 \\
1,975 \\
474 \\
178 \\
44 \\
35 \\
-\end{array}$ & $\begin{array}{r}285,672 \\
70,954 \\
1,056,023 \\
191,485 \\
70,124 \\
6,103 \\
17,650\end{array}$ & $\begin{array}{r}518 \\
390 \\
1,797 \\
395 \\
352 \\
168 \\
33\end{array}$ & $\begin{array}{r}176,399 \\
13,209 \\
1,032,206 \\
170,345 \\
65,903 \\
23,368 \\
16,335\end{array}$ & $\begin{array}{r}830 \\
1,482 \\
84 \\
847 \\
141 \\
- \\
- \\
98\end{array}$ & $\begin{array}{r}364,316 \\
935,686 \\
361,77 \\
68,150\end{array}$ \\
\hline 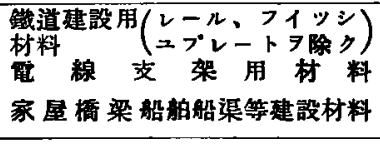 & $\begin{array}{l}2,982 \\
1,481 \\
3,132\end{array}$ & $\begin{array}{l}354,660 \\
294,779 \\
928,200\end{array}$ & $\begin{array}{r}198 \\
3 \\
5,431\end{array}$ & $\begin{array}{r}313,257 \\
9,412 \\
1,453,854\end{array}$ & $\begin{array}{r}99 \\
5,011\end{array}$ & $1,467,467$ \\
\hline 嘼 & 11,275 & $3,275,650$ & 9,285 & $3,274,288$ & 8,508 & $3,260,14$ \\
\hline 合 & 831,961 & $108,513,092$ & 817,654 & $100,868,413$ & 929,613 & $115,538 \mathrm{~B}$ \\
\hline 的 & $3,528,126$ & $172,109,896$ & $2,570,190$ & $146,832,183$ & $2,265,852$ & $146,986,19$ \\
\hline
\end{tabular}




\section{內地鐵鑛及鐵鋼材輸入表}

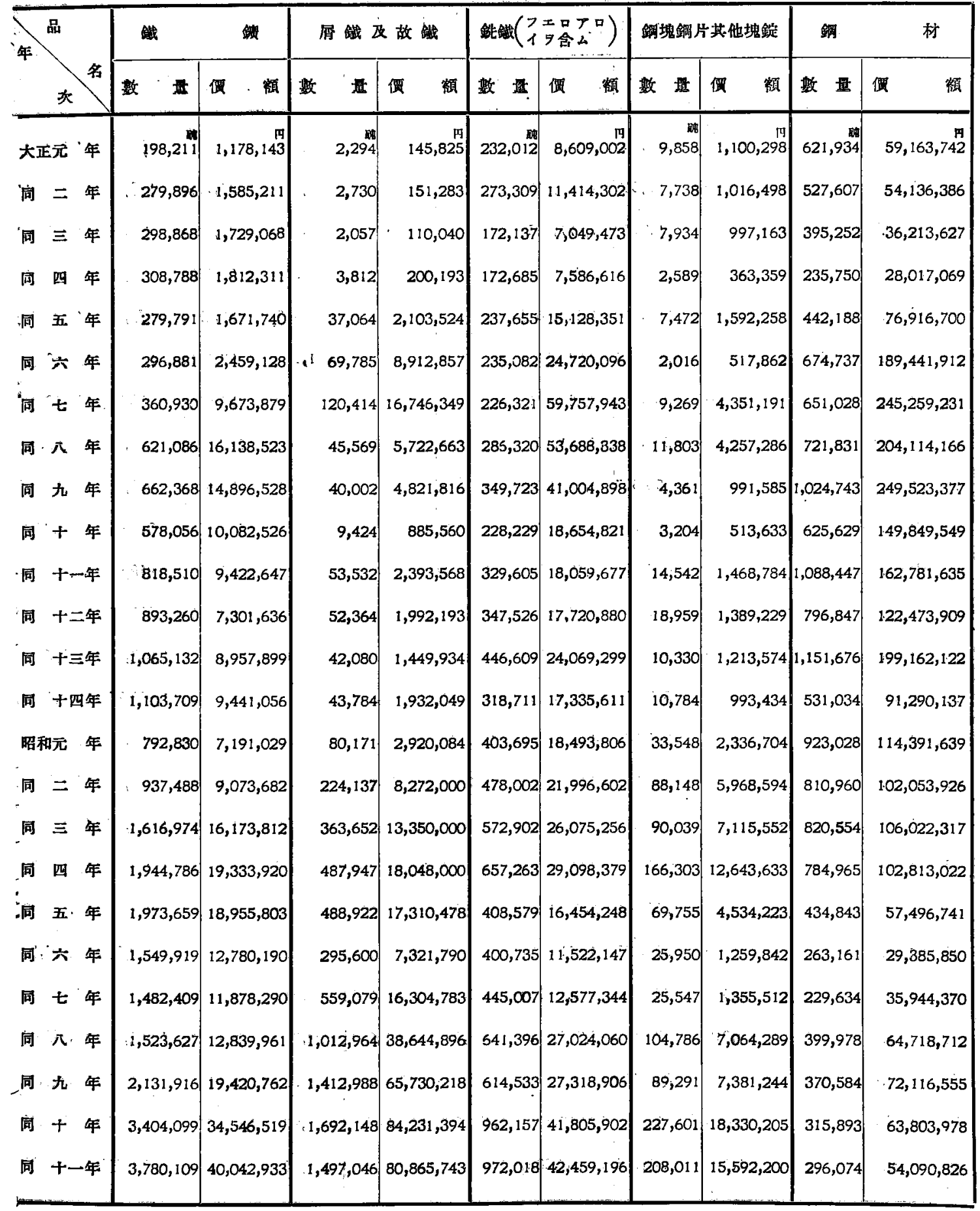

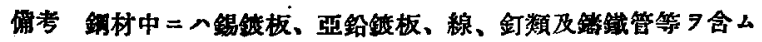




\section{內地鐵鐄輸入國別表}

\begin{tabular}{|c|c|c|c|c|c|c|c|c|c|c|c|}
\hline \multirow{2}{*}{\multicolumn{2}{|c|}{ 年 }} & 溯 & \multirow{2}{*}{ 洲 } & \multicolumn{2}{|c|}{ 中茟 民国 } & \multicolumn{2}{|c|}{ 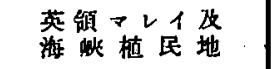 } & 其 & 他 & \multicolumn{2}{|l|}{ 合 } \\
\hline & & 数 & & 量 & 顧 & 表 & 徐 & 数 堤 & 矤 & 教 星 & 僄 \\
\hline 大正 & E元 年 & أ & $\mathbf{A}$ & 195,625! & $1,100,748$ & - & m & 2,586 & $\begin{array}{r}\text { 口 } \\
77,395\end{array}$ & 198,211 & $1,178,148$ \\
\hline 同 & 二 年 & - & - & $277,883^{\prime}$ & $1,537,012$ & - & - & 2,013 & 48,199 & 279,896 & $1,585,211$ \\
\hline 同 & 三 年 & - & - & 297,183 & $1,671,428$ & - & - & 1,685 & 57,640 & 298,868 & $1,729,008$ \\
\hline & 四 年 & - & - & 308,074 & $1,786,324$ & - & - & 714 & 25,987 & 308,798 & $1,812,311$ \\
\hline 同 & 五 年 & - & - & 279,216 & $1,641,467$ & - & - & 575 & 30,273 & 279,791 & $1,671,740$ \\
\hline 同 & 六 年 & - & - & 295,588 & $2,382,011$ & - & - & 1,193 & 77,117 & 296,881 & $2,459,18$ \\
\hline 同 & 七 年 & - & - & 359,698 & $9,601,071$ & - & - & 1,232 & 72,808 & 360,930 & $9,673,879$ \\
\hline 阙 & 八 年 & - & - & 595,140 & $15,331,000$ & 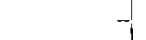 & - & 25,946 & 807,523 & 621,086 & 16,138 \\
\hline 洞 & 九 年 & - & - & 650,527 & $14,372,905$ & - & - & 11,841 & 523,623 & 662,368 & 14,896 \\
\hline 同 & 十年 & - & - & 439,769 & $7,265,693$ & （不形 $=$ 付 & $r($ 他 $=$ 前人) & 138,287 & $2,816,833$ & 578,056 & 10,082 \\
\hline 同 & 十一年 & - & - & 644,730 & $6,621,733$ & 6 & 2 & 173,780 & $2,800,914$ & 818,510 & $9,422,647$ \\
\hline 同 & 十二年 & - & - & $661,796^{\prime}$ & $4,855,092$ & 163,441 & $1,737,607$ & 68,023 & 708,937 & 893,260 & $7,301,636$ \\
\hline 同 & 十三年 & - & - & 800,157 & $6,109,856$ & 264,933 & $2,844,484$ & $42^{i}$ & 3,559 & $1,065,132$ & $8,957,899$ \\
\hline 同 & 十四年 & - & - & 813,490 & $6,299,131$ & 290,213 & $3,141,738$ & 6 & 187 & $1,103,709$ & 9,441 \\
\hline 昭和 & 吅元 年 & - & - & 502,747 & $4,002,336$ & 290,053 & $3,167,732$ & 30 & 961 & 792,830 & 7,19 \\
\hline & 二 年 & - & - & 502,597 & $4,264,276$ & 434,837 & $4,804,962$ & 54 & 4,444 & 937,488 & 9,07 \\
\hline 同 & 三年 & - & - & 877,841 & $8,001,243$ & 738,502 & $8,139,320$ & 631 & 33,249 & $1,616,974$ & 16,17 \\
\hline 同 & 四年 & - & - & 950,303 & $8,550,609$ & 958,619 & $10,396,455$ & 35,864 & 386,856 & $1,944,786$ & 19,3 \\
\hline 间 & 五 年 & - & - & 790,566 & $6,723,256$ & 997,891 & $10,401,074$ & $185,20 ?$ & $1,831,463$ & $1,973,659$ & 18,95 \\
\hline 同 & 六 年 & - & - & 593,589 & $4,191,375$ & 921,601 & $8,274,966$ & 34,729 & 313,849 & $1,549,919$ & 12,78 \\
\hline 同 & 七 年 & 6,182 & 45,417 & 557,092 & $3,726,975$ & 877,886 & $7,638,963$ & 41,249 & 466,935 & $1,482,409$ & 11,87 \\
\hline 同 & 八 年 & 206 & 4,010 & 573,467 & $3,966,068$ & 927,232 & $8,573,201$ & 22,722 & 296,682 & $1,523,627$ & 12,83 \\
\hline & 九 年 & 3,307 & 34,788 & $825,46 \mathrm{I}$ & $6,389,995$ & 873,395 & $8,505,651$ & $429,753^{\prime}$ & $4,490,328$ & $2,131,916$ & 19,42 \\
\hline & 十年 & 58 & 628 & $1,261,786$ & $10,915,609$ & $1,474,282$ & $15,024,001$ & 667,973 & $8,606,281$ & $3,404,099$ & 34,54 \\
\hline 同 & 十一年 & 66 & 1,164 & $1,251,908$ & $11,607,282$ & $1,691,432$ & $18,131,873$ & $836,703^{\prime}$ & $10,302,614$ & $3,780,109$ & \\
\hline
\end{tabular}

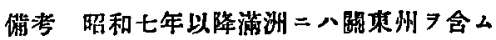


內地肩鐵及故

\begin{tabular}{|c|c|c|c|c|c|c|c|c|c|c|}
\hline \multirow{2}{*}{ 國年 } & \multicolumn{2}{|c|}{ 炤 和 十一年 } & \multicolumn{2}{|c|}{ 昭 和 十 年 } & \multicolumn{2}{|c|}{ 昭 和 九 年 } & \multicolumn{2}{|c|}{ 昭 和 八 年 } & \multicolumn{2}{|c|}{ 昭 和 七 年 } \\
\hline & 数 贯 & 額 & 理 & 㑭 & 數 境 & 洒 & 数 理 & 㵋 & 数 量 & 洒 \\
\hline & 19,962 & 922,027 & 4,101 & 218,307 & 5,180 & 228,799 & $\begin{array}{l}\text { हnन } \\
6,878\end{array}$ & $225,590^{\prime \prime}$ & 2,675 & \\
\hline 東 & 11,148 & 493,254 & 2,120 & 88,204 & 1,808 & 64,279 & 2,986 & 97,594 & 6,339 & \\
\hline 中灌 民國 & 30,071 & $1,416,941$ & 5,920 & 279,709 & 12,989 & 504,397 & 20,002 & 726,201 & 9,917 & 232 \\
\hline 英 領 印 度 & 139,484 & $7,135,791$ & 96,771 & $4,667,094$ & 100,400 & $4,545,758$ & 194,683 & $7,922,500$ & 113,272 & $2,857,78$ \\
\hline 海跠植民地 & 15,362 & 789,183 & 12,330 & 613,080 & 14,352 & 617,950 & 11,850 & 456,233 & 9,180 & 233 \\
\hline 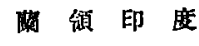 & 63,463 & $3,215,599$ & 37,199 & $2,229,564$ & 34,190 & $1,522,965$ & 27,641 & $1,044,569$ & 18,164 & $455,38 \mathrm{~B}$ \\
\hline 露領 亞 湅 亞 & 7 & 335 & - & - & 3,064 & 73,123 & 1,089 & 22,114 & 8,405 & 186 \\
\hline 吉 & 5,757 & 396,241 & 40,417 & $2,499,451$ & 95,645 & $3,875,858$ & 124,392 & $4,447,05$ & 98,040 & $3,390,758$ \\
\hline 獨 & 1,886 & 123,693 & 5,984 & 379,667 & 10,950 & 457,103 & 5,269 & 305,554 & 7,042 & 249,5 \\
\hline 耳 & 7,669 & 539,388 & 23,964 & $1,603,907$ & 17,638 & $1,193,064$ & 20,275 & $1,305,292$ & 18,595 & 581 \\
\hline 和 & 641 & 42,575 & 921 & 59,515 & 2,873 & 175,609 & 9,266 & 395,640 & 25,725 & \\
\hline 北米合衆國 & $1,027,682$ & $56,304,867$ & $1,326,171$ & $65,182,747$ & 960,032 & $45,564,065$ & 454,520 & $16,673,425$ & 154,798 & 4,673 \\
\hline 南 阿 㷁 邦 & 10,586 & 555,430 & 4,190 & 241,114 & 6,488 & 272,140 & 8,084 & 291,541 & 28,712 & 781, \\
\hline 東部亞弗利加 & 10,258 & 520,630 & 3,499 & 159,152 & 1,628 & $.72,455$ & 3,141 & 109,413 & 11,099 & 307, \\
\hline 浇 太刺 利 & 56,865 & $3,012,558$ & 48,638 & $2,511,357$ & 48,269 & $2,223,015$ & 35,140 & $1,410,688$ & 28,594 & 693,6003 \\
\hline 其 & 96,205 & $5,397,231$ & 79,923 & \begin{tabular}{l|l}
3 & $3,498,256$
\end{tabular} & 97,482 & $4,339,638$ & 87,748 & $3,211,491$ & 18,072 & \\
\hline 計 & $1,497,046$ & $80,865,743$ & $1,692,148$ & B $84,231,394$ & $1,412,988$ & $65,730,218$ & $1,012,964$ & $38,644,896$ & 559,079 & 16,304 \\
\hline
\end{tabular}




\section{鐵輸入國別表}

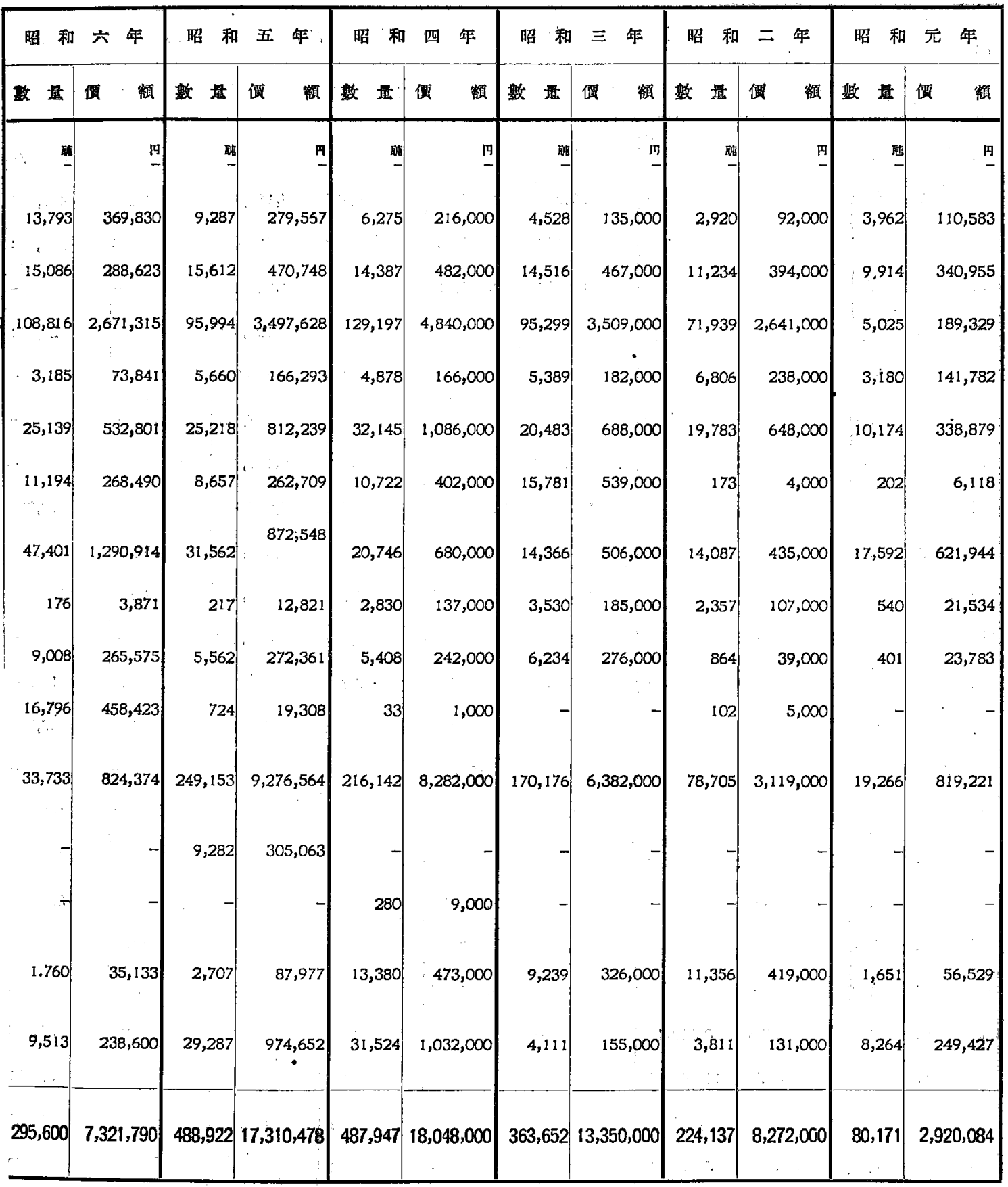




\begin{tabular}{|c|c|c|c|c|c|c|c|c|c|c|c|}
\hline 年 & 國 & & & & 洲 & 中 曅 & 民國 & 英 & 利: & 城 & 逼 \\
\hline & 次 & 名 & 数 & 量 & 瀷 & 贯 & 俓 & 數 & 侕 & 堪 & 詈 \\
\hline 大正 & 元 & 年 & & nt & 모- & 7,285 & 219,022 & 157,039 & $5,585,502$ & 8,224 & 308,371 \\
\hline 间 & $=$ & 年 & & & - & 59,945 & $2,054,099$ & 99,430 & $4,164,059$ & 11,278 & 441,038 \\
\hline 同 & $\equiv$ & 年 & & - & - & 55,188 & $1,940,036$ & 60,214 & $2,518,437$ & 6,354 & 224,324 \\
\hline 同 & 四 & 年 & & - & - & 82,904 & $2,889,011$ & 36,729 & $1,826,193$ & - & \\
\hline 同 & 伍 & 年 & & - & - & 102,383 & $5,028,534$ & 31,615 & $2,105,466$ & 364 & 26,364 \\
\hline 同： & :六 & 年. & & & - & 109,768 & 9,$337 ; 678$ & 5,462 & 625,044 & & \\
\hline 闹 & $t$ & 年 & & & - & 157,747 & $41,814,158$ & 17,846 & $3,877,627$ & & \\
\hline 同 & 八 & 年 & & - & - & 95,189 & $16,287,588$ & 44,762 & $9,128,852$ & & \\
\hline 同 & 九 & 年 & & & - & 140,740 & $14,552,572$ & 58,565 & $8,009,724$ & 500 & 28,300 \\
\hline 同、 & -1 & 年 & & & - & 76,160 & $5,066,540$ & 22,628 & $3,495,593$ & $3 ; 444$ & 294,355 \\
\hline 同 & + & 年 & & - & - & 129,274 & $6,790,895$ & 9,726 & 760,512 & $: 4,506$ & 260,145 \\
\hline 同 & + & & & - & - & 97,630 & $4,819,465$ & 6,365 & 406,204 & & \\
\hline 同 & + & & & - & - & 165,219 & $7,653,704$ & 7,809 & 518,540 & 203 & 10,740 \\
\hline 同 & + & & & - & - & 47,822 & $2,160,563$ & 8,185 & 535,918 & 711 & 47,753 \\
\hline 炤 和 & 元 & 年 & & & - & 3,796 & 187,037 & 7,595 & 433,307 & & : \\
\hline 同 & $=$ & & & J & - & 5,849 & $269,0,19$ & 6,727 & 340,769 & 2,266 & 165,822 \\
\hline 间 & $\equiv$ & 年 & & - & - & 30,748 & $1,463,384$ & 8,397 & 450,215 & 6,586 & 507,793 \\
\hline 同 & 四 & & & - & - & 56,836 & $2,794,863$ & 9,134 & 496,711 & 4,896 & 338,943 \\
\hline 同 & 五. & 年 & & - & - & 35,255 & $\lfloor, 482,351$ & 4,034 & 213,895 & 4,317 & 300,194 \\
\hline 同 & 六 & & & - & - & 77,735 & $2,356,527$ & 3,669 & 148,328 & 1,132 & 63,845 \\
\hline 可 & $t$ & & & 322,476 & $8,882,403$ & & & 2,947 & 166,597 & 310 & 30,345 \\
\hline 同 & 八 & & & 455,379 & $18,161,939$ & - & $\vdots$ & 2,797 & 216,347 & 324 & $39,05:$ \\
\hline 同 & 九 & 年 & & 409,427 & $18,968,274$ & 0 & 2 & 1,321 & 110,122 & 152 & 22,090 \\
\hline 同 & + & 年 & & 382,728 & $18,812,014$ & - & - & 2,504 & 195,410 & 406 & 53,979 \\
\hline 同 & + & & & 271,225 & $14,658,904$ & & & 2,263 & 220,364 & - & \\
\hline
\end{tabular}




\section{䡕一入 國 別表}

\begin{tabular}{|c|c|c|c|c|c|c|c|c|c|}
\hline 瑞 & 典 & 北 米 & 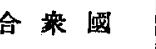 & 菼 & 度 & 其 & 他 & 合 & 計 \\
\hline 数 & 頼 & 数 迤 & 㵋 & 显 & 儥 & 聂 & 俳 & 数 & 瀷 \\
\hline 5,274 & $\begin{array}{r}\text { 19 } \\
336,476\end{array}$ & 608 & 19,709 & 50,065 & $1,679,554$ & ， 51 & $\begin{array}{r}19 \\
11,600\end{array}$ & 228,546 & $8,150,234$ \\
\hline$\therefore \quad 12,125$ & 783,736 & 406 & 15,451 & 81,881 & $2,931,370$ & 1 & 25 & 265,066 & $10,389,778$ \\
\hline 11,178 & 679,381 & 3,154 & 134,996 & 31,433 & $1,046,764$ & 1,573 & 51,304 & 169,094 & $6,595,242$ \\
\hline 6,868 & 473,550 & 1,017 & 62,512 & 38,040 & $1,233,301$ & 1,285 & 64,390 & 166.843 & $6,548,957$ \\
\hline 2,777 & 243,582 & 3,683 & 354,407 & 62,750 & $3,613,216$ & 28,476 & $2,421,733$ & 232,048 & $13,794,302$ \\
\hline 3,767 & 708,892 & 24,816 & 3,$224 ; 940$ & 61,119 & $5,318,302$ & 27,320 & $4,633,469$ & 232,252 & $23,848,325$ \\
\hline 4,217 & $1,034,99 i$ & 13,010 & $2,998,422$ & 7,054 & 911,420 & 25,226 & $8.455,719$ & 225,100 & $59,092,337$ \\
\hline 10,783 & $2,761,740$ & 35,560 & $6,291,553$ & 28,850 & $4,744,259$ & 68,012 & $12,931,342$ & 283,166 & $52,145,334$ \\
\hline 14,158 & $2,643,469$ & 35,512 & $3,751,755$ & 47,921 & $5,291,204$ & 51,252 & $6,282,009$ & 348,648 & $40,559,033$ \\
\hline 18,065 & $2,826,156$ & 1,247 & 133,579 & 34,351 & $2,745,600$ & 71,197 & $3,784,883$ & 227,092 & $18,346,706$ \\
\hline 4,066 & 392,74 & ${ }^{\prime} 1,245$ & 86,299 & 100,656 & $5,620,299$ & 78,503 & $3,852,390$ & 327,976 & $17,763,254$ \\
\hline 662 & 57,707 & 25 & 2,836 & 136,929 & $6,570,254$ & 104,422 & $5,596,587$ & 346,033 & $17,453,053$ \\
\hline 14,075 & $1,259,017$ & $\begin{array}{ll}31 \\
-3\end{array}$ & 3,173 & 159,978 & $8,384,480$ & 94,629 & $5,257,568$ & 441,944 & $23,087,222$ \\
\hline (2,958 & 255,705 & 86 & 9,597 & 153,332 & $8,481,433$ & 103,265 & $5,167,364$ & 316,359 & $16,658,333$ \\
\hline$\because 238$ & $\quad 19,531$ & 102 & 9,675 & 227,628 & $9,547,944$ & $\mathrm{i} 60,381$ & $7,400,767$ & 399,640 & $17,598,261$ \\
\hline 2,197 & $-149,806$ & $\therefore 102$ & 9,361 & 261,130 & $11,040,161$ & 194,676 & $8,999,942$ & 472,947 & $20,975,480$ \\
\hline 1,695 & 132,971 & 27,766 & $1,168,770$ & 310,489 & $12,929,854$ & 183,533 & $8,601,325$ & 569,214 & $25,254,312$ \\
\hline 814 & 62,429 & 30,474 & $1,177,616$ & 411,477 & $17,049,686$ & 140,424 & $6,515,218$ & 654,055 & $28,435,466$ \\
\hline 1,960 & $-151,861$ & 1,761 & 90,417 & 214,374 & $7,666,834$ & 144,128 & $5,940,256$ & 405,829 & $15,845^{‘} 808$ \\
\hline 1,469 & $\because 70,081$ & 540 & 39,625 & 150,491 & $3,626,284$ & 164,412 & $4,924,377$ & 399,448 & $11,229,067$ \\
\hline 520 & $\because 36,164$ & $\because 310$ & 30,565 & 117,862 & $3,027,734$ & - & - & 444,425 & $12,173,808$ \\
\hline 10,003 & 992,469 & 254 & 34,628 & 172,060 & $5,802,808$ & 35 & 4,517 & 640,852 & $25,251,759$ \\
\hline 256 & 28,291 & 773 & 83,822 & 202,154 & $7,292,397$ & 315 & 23,473 & 614,398 & $26,528,461$ \\
\hline 610 & $\because 64,311$ & 852 & 98,752 & 338,332 & $12,728,281$ & 236,482 & $9,227,215$ & 961,914 & $41,179,962$ \\
\hline$\quad 63$ & 6,633 & $\cdots \quad 573$ & 67,685 & 375,323 & $14,569,724$ & 322,522 & $12,540,782$ & 971,969 & $42,064,092$ \\
\hline
\end{tabular}


内地フエロ”口

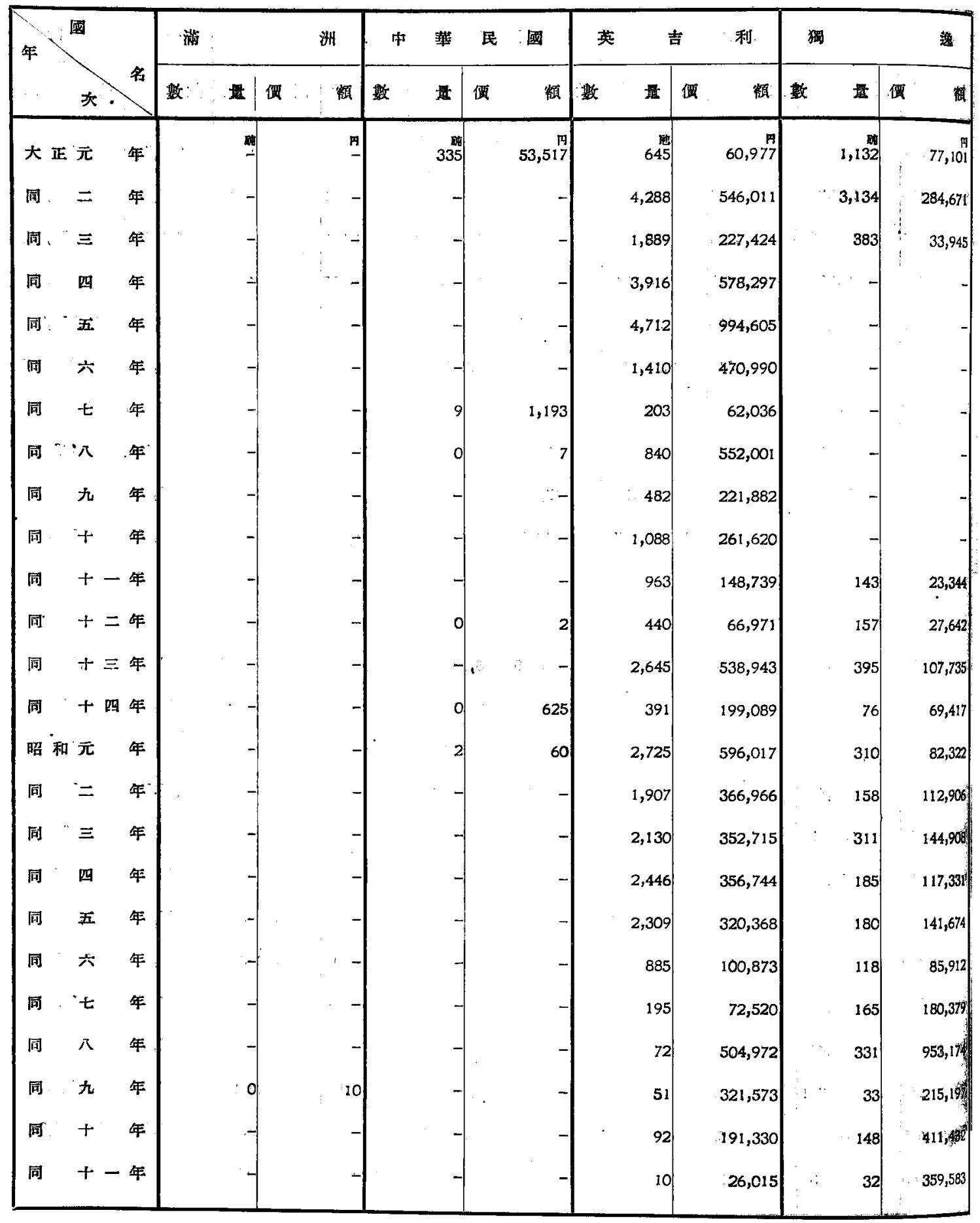




\section{1 輸入國別表}

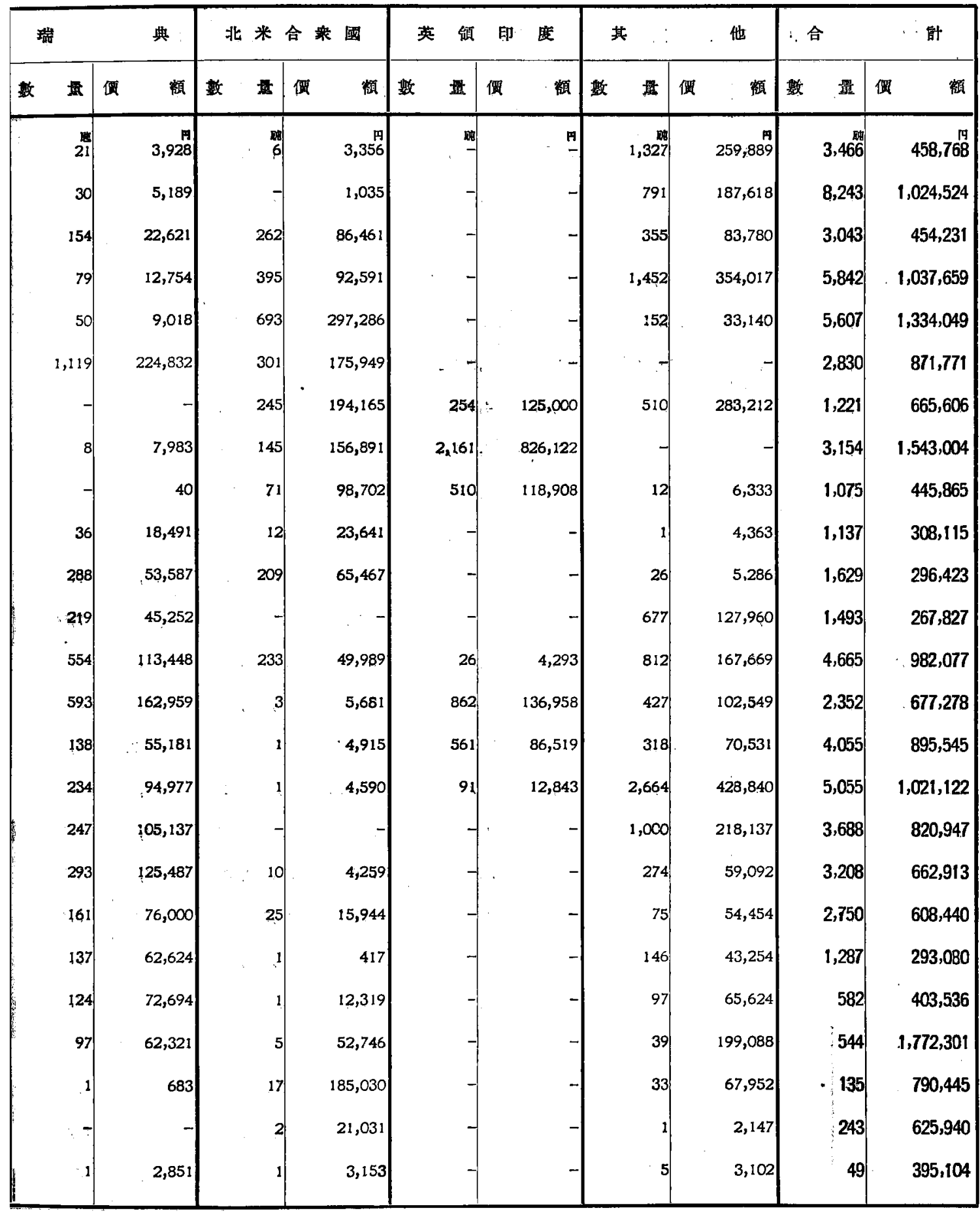


内地 鋼 材

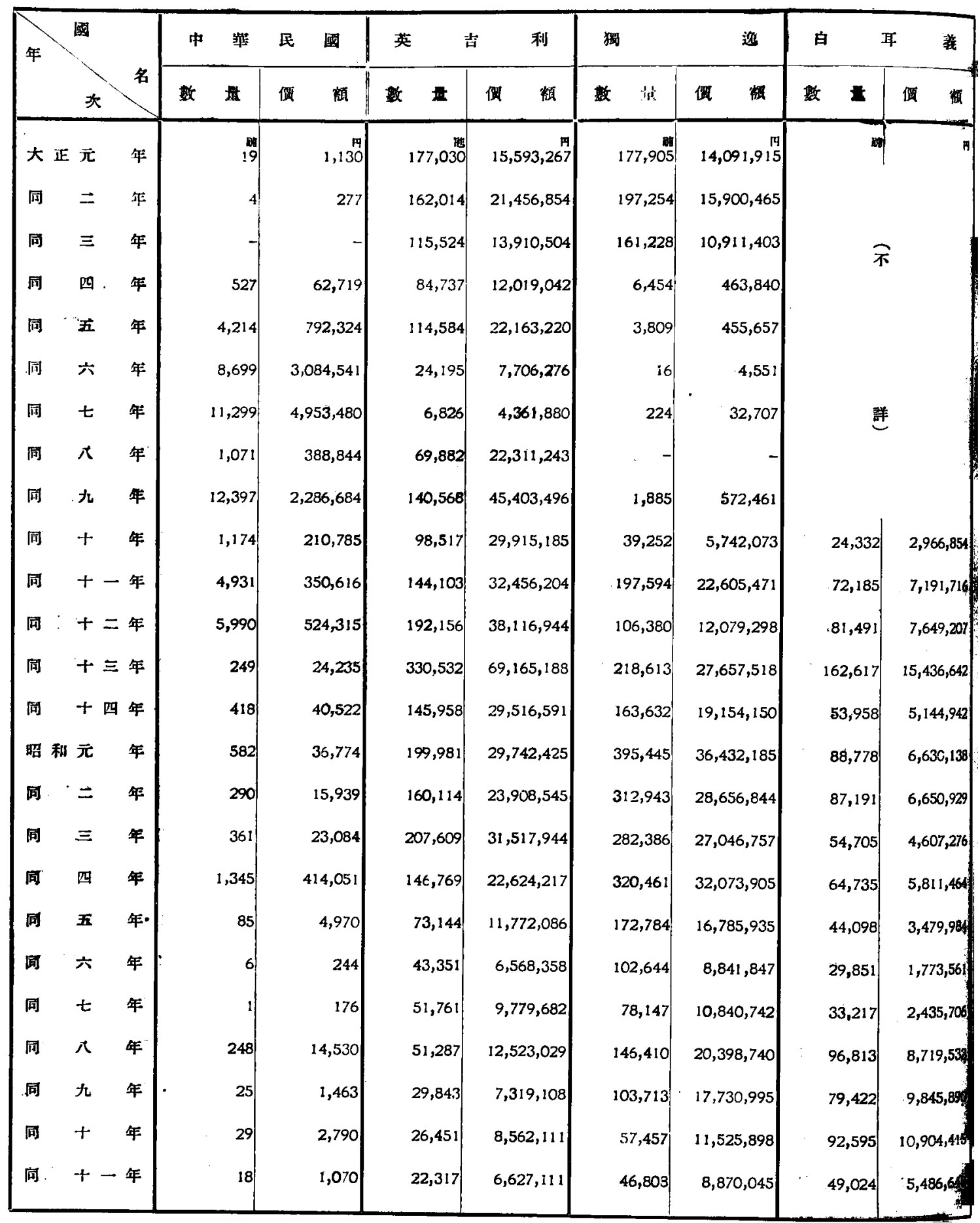

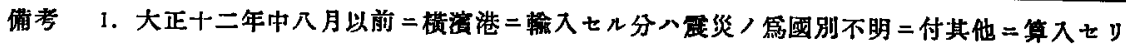

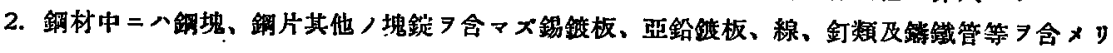




\section{輸入國別表}

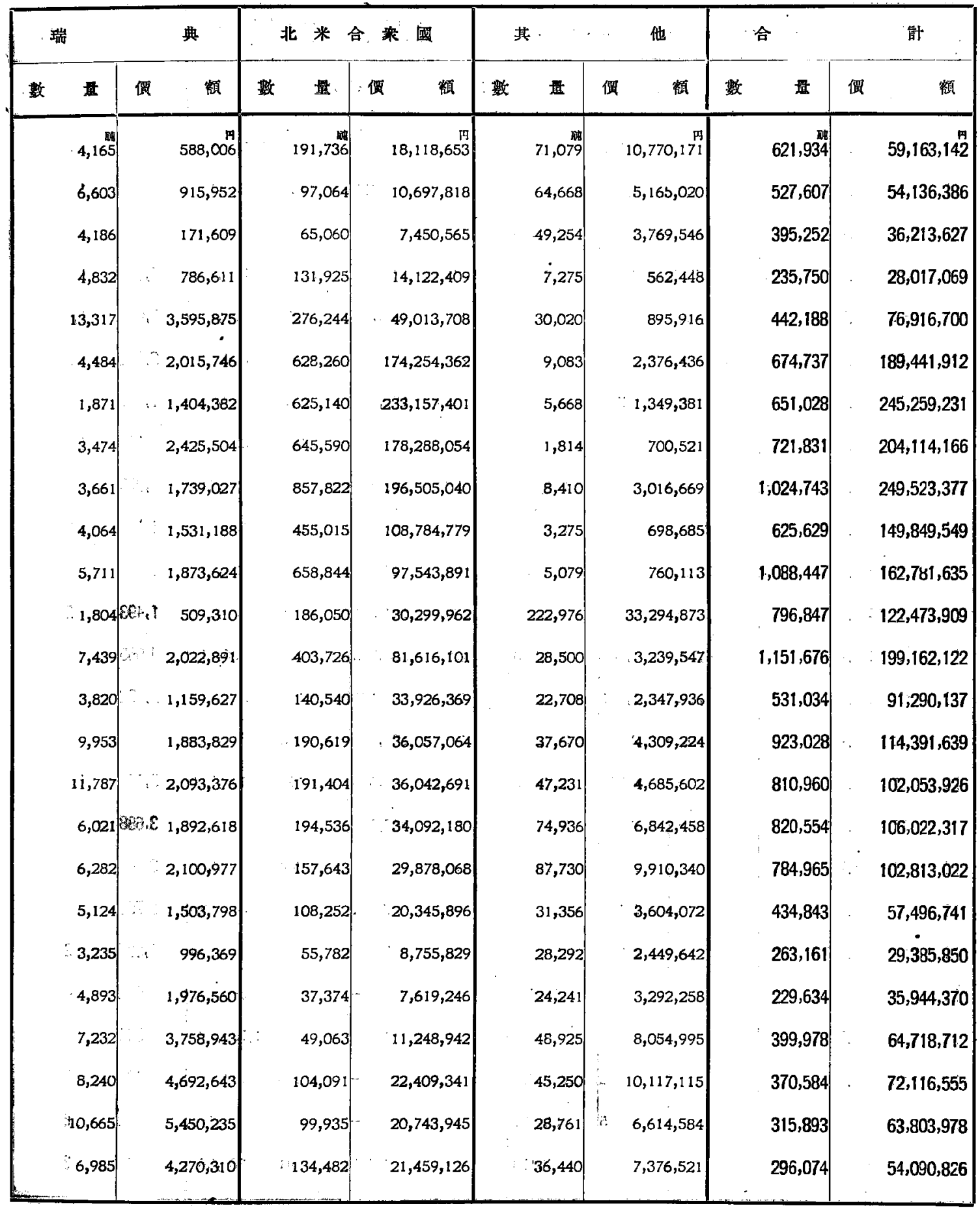


內地フエロアロイ輸入品種別表

\begin{tabular}{|c|c|c|c|c|c|c|c|c|c|c|c|c|}
\hline \multirow[t]{2}{*}{ 年 } & & \multirow{2}{*}{ 名 } & \multicolumn{2}{|c|}{ 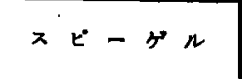 } & \multicolumn{2}{|c|}{ フェロマンガン } & \multicolumn{2}{|c|}{$\begin{array}{l}\text { フロジコン及 } \\
\text { ショコスビーゲル }\end{array}$} & \multicolumn{2}{|c|}{ 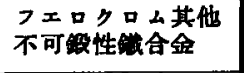 } & \multicolumn{2}{|l|}{ 合 } \\
\hline & & & 量 & 頭 & 数 & 顧 & 数 责 & 稹 & 数 量 & 促 & 数，昔 & 揀 \\
\hline 大 & 元 & 年 & 804 & 43,890 & 1,107 & 100,293 & $\begin{array}{r}\text { 缡 } \\
865\end{array}$ & $99,95 i^{\text {PI }}$ & 690 & 214,634 & 3,466 & \\
\hline & $=$ & 年 & 1,814 & 109,170 & 4,047 & 514,527 & 1,709 & 169,677 & 673 & 231,150 & 8,243 & $1,024,524$ \\
\hline 同 & 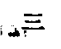 & 年 & 655 & 45,331 & 1,084 & 131,458 & 1,097 & 190,746 & 207 & 86,696 & 3,043 & 454,23 \\
\hline 同 & 四 & 年 & 579 & 44,797 & 2,654 & 423,543 & 1,538 & 247,752 & 1,071 & 321,567 & 5,842 & $1,037,65 ?$ \\
\hline 同 & 五 & 年 & 940 & 88,579 & 2,351 & 583,146 & 1,971 & 458,763 & 345 & 203,561 & 5,607 & $1,334,049$ \\
\hline 同 & 六 & 年 & 1,227 & 190,107 & 603 & 195,171 & 465 & 151,944 & 535 & 334,549 & $\therefore 2,830$ & 871,771 \\
\hline 同 & $t$ & 年 & 9 & 1,193 & 764 & 408,128 & 376 & 155,964 & 72 & 100,321 & $, 1,221$ & 665,606 \\
\hline 同 & 八 & 年 & -1 & - & 2,519 & 960,440 & 296 & 209,547 & 339 & 373,017 & 3,154 & $1,543,004$ \\
\hline 同 & 九 & 年 & - & - & 510 & 118,908 & 447 & 127,708 & 118 & 199,249 & 1,075 & 445,865 \\
\hline 同 & + & 年 & 10 & 2,966 & 707 & 119,938 & 150 & 26,794 & 270 & 158,417 & 1,137 & 308,115 \\
\hline 同 & + & 年 & 1 & 7,190 & 1,157 & 182,730 & 464 & 85,440 & 7 & 21,063 & 1,629 & 296,48 \\
\hline 同 & + & & -1 & - & .555 & 93,865 & 873 & 144,681 & 65 & 29,281 & 1,493 & 267,829 \\
\hline 问 & + & 年 & 26 & 4,293 & 3,181 & 605,383 & 1,340 & 275,752 & 118 & 96,649 & 4,665 & 982,07 \\
\hline 同 & + & 年 & 52 & 9,402 & 1,411 & 256,416 & 739 & 186,188 & 150 & 225,272 & 2,352 & 677,278 \\
\hline 昭 & $\bar{\pi}$ & 年 & 2 & 60 & 2,692 & 396,265 & 746 & 137,746 & 615 & 361,474 & 4,055 & 895,545 \\
\hline 同 & $=$ & & - & - & 3,396 & 520,523 & 1,467 & 300,848 & 192 & 199,751 & 5,055 & $1,021,122$ \\
\hline 同 & $\equiv$ & 年 & - & - & 2,097 & 300,878 & 1,198 & 269,862 & 393 & 250,207 & 3,688 & 820,947 \\
\hline 同 & 四 & & - & - & 2,468 & 357,496 & 396 & 94,094 & 344 & 211,323 & 3,208 & 662,913 \\
\hline 同 & 五 & & & - & 2,132 & 271,950 & 60 & 17,034 & 558 & 319,456 & $\therefore 2,750$ & 608,440 \\
\hline 同 & 六 & 年 & & - & 917 & 98,738 & 52 & 7,484 & 318 & 186,858 & 1,287 & 293,080 \\
\hline 同 & $t$ & 年 & & - & 201 & 33,566 & - & - & 381 & 369,970 & 582 & 403,536 \\
\hline 同 & $\pi$ & 年 & $n-1$ & - & 10 & 13,088 & 3 & 1,837 & 531 & $1,757,376$ & 544 & $1,772,301$ \\
\hline 同 & 九 & 年 & $\because \because-1$ & - & 2 & 8,790 & - & - & 133 & 781,655 & 135 & 790,445 \\
\hline 同 & + & 年 & & - & 5 & 30,137 & - & - & 238 & 595,803 & 243 & 625,940 \\
\hline 同 & + & & $\pi, 2:-1$ & - & 6 & 7,174 & 2 & 1,343 & 41 & 386,587 & 49 & 395,104 \\
\hline
\end{tabular}




\section{內地鋼材輸入品種別表}

（其 一)

\begin{tabular}{|c|c|c|c|c|c|c|}
\hline 年 & 昭 和 & 一 年 & 昭 & + & 昭 & 九 \\
\hline 名 & 数 & 額 & 數 & 㴶 & 数 & 偠 \\
\hline 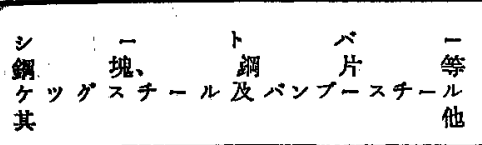 & \begin{tabular}{r|r|} 
㩆 \\
134,511 \\
72,863 \\
299 \\
338
\end{tabular} & $\begin{array}{r}\mathrm{p} \\
10,067,503 \\
5,251,841 \\
133,805 \\
139,051\end{array}$ & $\begin{array}{r}\text { 畉 } \\
163,097 \\
63,721 \\
262 \\
521\end{array}$ & $\begin{array}{r}13,051,927 \\
5,121,562 \\
117,059 \\
39,657\end{array}$ & \begin{tabular}{r|r|r}
61,393 \\
27,747 \\
151
\end{tabular} & $\begin{array}{r}5,018,933 \\
2,301,174 \\
61,137\end{array}$ \\
\hline 㖕 & 208,011 & $15,592,200$ & 227,601 & $18,330,205$ & 89,291 & $7,381,244$ \\
\hline 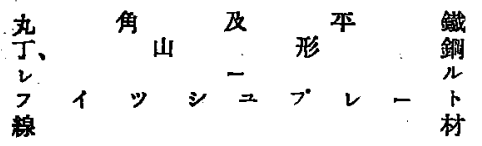 & $\begin{array}{r}25,125 \\
11,877 \\
48,479 \\
29 \\
37,515\end{array}$ & $\begin{array}{r}4,105,650 \\
1,599,501 \\
2,880,308 \\
2,162 \\
4,648,935\end{array}$ & $\begin{array}{r}29,57 ? \\
27,967 \\
19,187 \\
99 \\
44,551\end{array}$ & $\begin{array}{r}\mathbf{4}, 653,685 \\
3,041,744 \\
1,153,787 \\
22,655 \\
\mathbf{5}, 350,314\end{array}$ & $\begin{array}{r}35,1 \\
28,731 \\
6,914 \\
65 \\
32,416\end{array}$ & $\begin{array}{r}4,932,187 \\
2,778,344 \\
416,525 \\
\quad 5,375 \\
4,107,520\end{array}$ \\
\hline 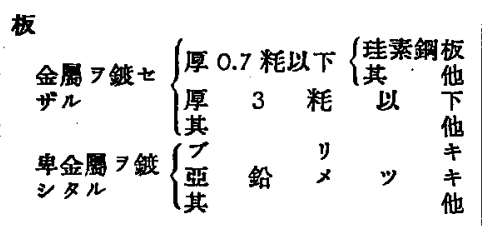 & $\begin{array}{r}1,747 \\
2,092 \\
12,726 \\
14,353 \\
51,170 \\
94 \\
1,151\end{array}$ & $\begin{array}{r}469,383 \\
386,645 \\
1,655,588 \\
1,905,610 \\
14,237,907 \\
22,839 \\
183,102\end{array}$ & $\begin{array}{r}5,611 \\
5,032 \\
17,272 \\
21,751 \\
53,827 \\
374 \\
452\end{array}$ & $\begin{array}{r}1,763,116 \\
1,026,010 \\
2,444,647 \\
2,743,089 \\
16,483,326 \\
70,323 \\
102,286\end{array}$ & $\begin{array}{r}1,893 \\
837 \\
11,839 \\
54,265 \\
88,082 \\
1,188 \\
35\end{array}$ & $\begin{array}{r}554,545 \\
170,543 \\
1,751,243 \\
5,881,324 \\
25,698,173 \\
166,590 \\
29,887\end{array}$ \\
\hline 楾晴金閩 & $\begin{array}{r}153 \\
1,225\end{array}$ & $\begin{array}{r}30,718 \\
958,747\end{array}$ & $\begin{array}{r}138 \\
1,257\end{array}$ & $\begin{array}{r}28,451 \\
868,695\end{array}$ & $\begin{array}{r}117 \\
1,788\end{array}$ & $\begin{array}{r}34,697 \\
805,680\end{array}$ \\
\hline 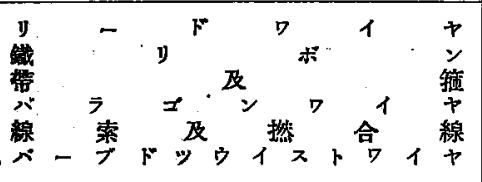 & $\begin{array}{r}8 \\
2,467 \\
31,946 \\
50 \\
196\end{array}$ & $\begin{array}{r}4,460 \\
2 ; 007,479 \\
3,783,368 \\
30,587 \\
192,445\end{array}$ & $\begin{array}{r}5,986 \\
54,416 \\
45 \\
246 \\
0\end{array}$ & $\begin{array}{r}6,472 \\
2,872,652 \\
7,028,798 \\
29,711 \\
251,603 \\
3\end{array}$ & $\begin{array}{r}2 \\
7,538 \\
76,600 \\
47 \\
194\end{array}$ & $\begin{array}{r}5,879 \\
2,950,418 \\
9,869,847 \\
\quad 30,057 \\
\therefore \quad 195,143\end{array}$ \\
\hline 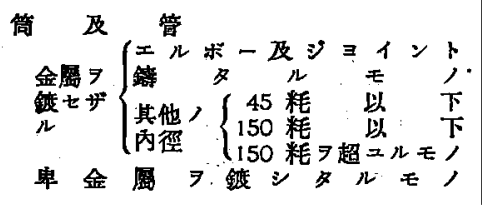 & $\begin{array}{r}10 \\
7 \\
38,360 \\
4,521 \\
-\end{array}$ & $\begin{array}{r}18,805 \\
3,277 \\
5,791,405 \\
1,086,598 \\
439\end{array}$ & $\begin{array}{r}39 \\
13 \\
12,310 \\
4,589 \\
78\end{array}$ & $\begin{array}{r}35,918 \\
1,570 \\
2,706,101 \\
1,678,944 \\
25,177\end{array}$ & $\begin{array}{r}415 \\
19 \\
9,761 \\
4,584 \\
9\end{array}$ & $\begin{array}{r}190,336 \\
3,796 \\
2,548,447 \\
1,673,823 \\
5,429\end{array}$ \\
\hline 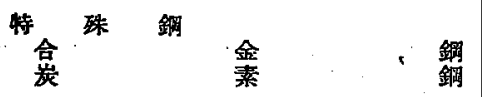 & $\begin{array}{r}9,363 \\
310\end{array}$ & $\begin{array}{r}7,134,727 \\
116,196\end{array}$ & $\begin{array}{r}9,745 \\
334\end{array}$ & $\begin{array}{r}8,285,620 \\
122,545\end{array}$ & $\begin{array}{r}6,854 \\
220\end{array}$ & $\begin{array}{r}6,224,992 \\
102,029\end{array}$ \\
\hline 暗 & 294,974 & $53,257,901$ & 314,898 & $62,798,242$ & 369,582 & $71,132,829$ \\
\hline 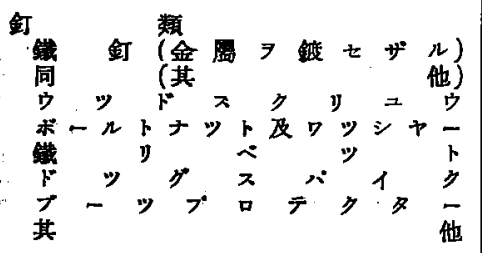 & $\begin{array}{r}443 \\
5 \\
14 \\
337 \\
84 \\
2 \\
2\end{array}$ & $\begin{array}{r}336,931 \\
5,668 \\
23,199 \\
284,505 \\
48,713 \\
1,688 \\
7,881\end{array}$ & \begin{tabular}{r|}
509 \\
29 \\
424
\end{tabular} & $\begin{array}{r}384,339 \\
24,912 \\
390,067 \\
167,914\end{array}$ & \begin{tabular}{r|r}
438 \\
51 \\
51 \\
407
\end{tabular} & $\begin{array}{r}328,345 \\
35,454 \\
346,509 \\
173,070\end{array}$ \\
\hline 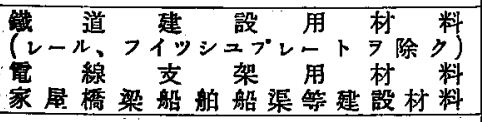 & $\begin{array}{r}72 \\
141 \\
\end{array}$ & $\begin{array}{r}15,284 \\
109,756 \\
\end{array}$ & 33 & $\begin{array}{r}15,858 \\
22,546 \\
\end{array}$ & $\begin{array}{r}0 \\
105 \\
\end{array}$ & $\begin{array}{r}39,960 \\
60,388 \\
\end{array}$ \\
\hline 部 & 1,100 & 832,925 & 995 & $1,005,736$ & 1,002 & 983,726 \\
\hline 合 & 296,074 & $54,090,826$ & 315,893 & $63,803,978$ & 370,584 & $72,116,555$ \\
\hline 練 & 504,085 & $69,683,026$ & 543,494 & $82,134,183$ & 459,875 & $79,497,799$ \\
\hline
\end{tabular}


内地 鋼 材 輸

（其

\begin{tabular}{|c|c|c|c|c|c|c|}
\hline 年 & 昭 & 年 & 炤 & $七$ & 昭 & 六 \\
\hline 名 17 & 量 & 蟫 & 敖 & 價 & 數 & 價 \\
\hline 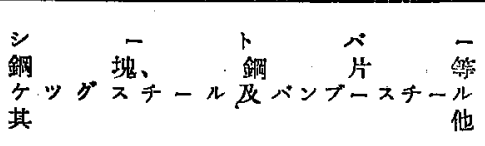 & $\begin{array}{r}65,038 \\
39,517 \\
229 \\
2\end{array}$ & $\begin{array}{r}\mathrm{m} \\
4,533,673 \\
2,440,020 \\
90,512 \\
84\end{array}$ & $\begin{array}{r}\text { nम } \\
12,314 \\
12,699 \\
530 \\
4\end{array}$ & $\begin{array}{r}111 \\
629,326 \\
558,594 \\
166,771 \\
821\end{array}$ & $\begin{array}{r}\text { nht } \\
23,719 \\
1,924 \\
296 \\
11\end{array}$ & $\begin{array}{r}1,077,478 \\
111,321 \\
68,457 \\
2,586\end{array}$ \\
\hline 合 & 104,786 & $7,064,289$ & 25,547 & $1,355,512$ & 25,950 & $1,259,842$ \\
\hline 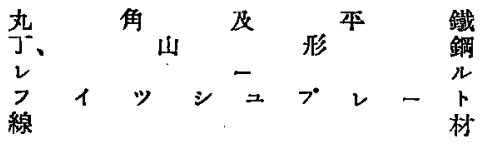 & $\begin{array}{r}41,614 \\
38,836 \\
3,852 \\
142 \\
38,794\end{array}$ & $\begin{array}{r}4,176,573 \\
3,662,662 \\
331,910 \\
14,307 \\
5,231,329\end{array}$ & $\begin{array}{r}15,739 \\
22,987 \\
5,660 \\
172 \\
27,890\end{array}$ & $\begin{array}{r}1,793,455 \\
2,664,491 \\
841,894 \\
32,744 \\
2,943,435\end{array}$ & $\begin{array}{r}21,531 \\
16,749 \\
5,963 \\
316 \\
65,168\end{array}$ & $\begin{array}{r}1,645,681 \\
1,730,579 \\
497,250 \\
37,976 \\
4,219,170\end{array}$ \\
\hline 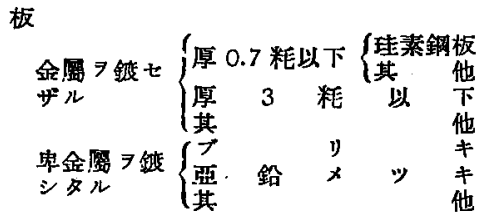 & $\begin{array}{r}1,249 \\
1,487 \\
13,954 \\
71,923 \\
79,915 \\
840 \\
2\end{array}$ & $\begin{array}{r}346,836 \\
309,331 \\
1,800,049 \\
6,196,205 \\
22,916,015 \\
155,912 \\
21,990\end{array}$ & $\begin{array}{r}2,475 \\
11,079 \\
3,902 \\
4,947 \\
63,470 \\
576 \\
2\end{array}$ & $\begin{array}{r}697,663 \\
1,279,855 \\
598,533 \\
442,504 \\
13,324,459 \\
88,217 \\
15,939\end{array}$ & $\begin{array}{r}2,700 \\
18,587 \\
4,799 \\
4,462 \\
47,749 \\
1,126 \\
146\end{array}$ & $\begin{array}{r}626,37 \\
1,980,4 \\
537,69 \\
318,0 \% \\
8,490,17 \\
152,041 \\
8,99\end{array}$ \\
\hline 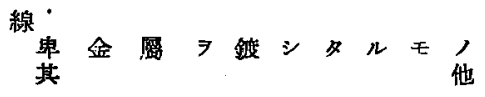 & $\begin{array}{r}170 \\
1,287\end{array}$ & $\begin{array}{r}59,154 \\
606,562\end{array}$ & $\begin{array}{r}627 \\
1,737\end{array}$ & $\begin{array}{l}125,368 \\
371,330\end{array}$ & $\begin{array}{l}2,595 \\
6,296\end{array}$ & $\begin{array}{l}260,48 \\
516,20\end{array}$ \\
\hline 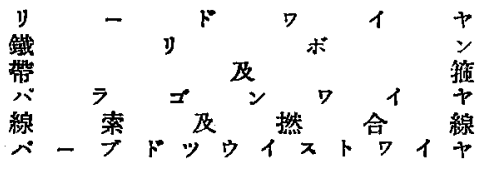 & $\begin{array}{r}105 \\
4,323 \\
83,706 \\
95 \\
189 \\
2\end{array}$ & $\begin{array}{r}16,407 \\
2,067,705 \\
8,275,234 \\
57,320 \\
211,339 \\
180\end{array}$ & $\begin{array}{r}4 \\
4,424 \\
47,655 \\
170 \\
250 \\
0\end{array}$ & $\begin{array}{r}9,793 \\
1,406,054 \\
3,607,637 \\
81,836 \\
193,061 \\
21\end{array}$ & $\begin{array}{r}8 \\
5,752 \\
40,038 \\
133 \\
391 \\
-\end{array}$ & 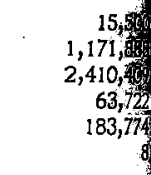 \\
\hline 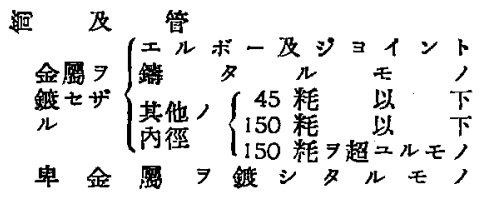 & $\begin{array}{r}955 \\
28 \\
5,392 \\
2,934 \\
24\end{array}$ & $\begin{array}{r}394,999 \\
3,888 \\
1,067,720 \\
1,110,301 \\
8,446\end{array}$ & $\begin{array}{r}411 \\
48 \\
4,652 \\
2,759 \\
498\end{array}$ & $\begin{array}{r}145,383 \\
12,415 \\
1,079,089 \\
886,439 \\
99,558\end{array}$ & $\begin{array}{r}199 \\
60 \\
3,857 \\
3,194 \\
2,203 \\
696\end{array}$ & $\begin{array}{r}84,564 \\
20,921 \\
488,637 \\
546,443 \\
528,198 \\
120,776\end{array}$ \\
\hline 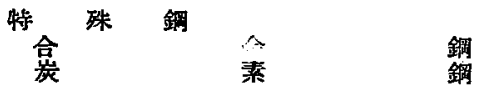 & $\begin{array}{r}6,769 \\
284\end{array}$ & $\begin{array}{r}4,744,103 \\
120,915\end{array}$ & $\begin{array}{r}2,775 \\
621\end{array}$ & $\begin{array}{r}1,801,635 \\
294,802\end{array}$ & $\begin{array}{r}1,578 \\
387\end{array}$ & $\begin{array}{r}34 \\
732,99 \\
151,96\end{array}$ \\
\hline 幛 & 398,871 & $63,907,392$ & 225,530 & $34,837,610$ & 256,683 & $27,540,94$ \\
\hline 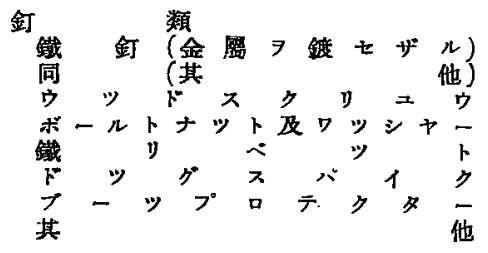 & $\begin{array}{r}458 \\
6 \\
279 \\
156 \\
55 \\
0 \\
66\end{array}$ & $\begin{array}{r}362,085 \\
5,347 \\
140,835 \\
155,578 \\
40,235 \\
2 \\
2,456 \\
-\end{array}$ & $\begin{array}{r}460 \\
7 \\
496 \\
173 \\
44 \\
- \\
1,983\end{array}$ & $\begin{array}{r}275,128 \\
6,498 \\
318,718 \\
146,296 \\
29,076 \\
- \\
18,309 \\
-\end{array}$ & $\begin{array}{r}465 \\
6 \\
1,335 \\
335 \\
68 \\
-1 \\
1,499 \\
-\end{array}$ & $\begin{array}{r}1 \\
189,169 \\
3,75 \\
688,58 \\
181,011 \\
28,711 \\
12,577\end{array}$ \\
\hline 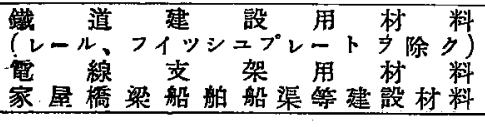 & $\begin{array}{r}- \\
- \\
\end{array}$ & - & $\begin{array}{r}40 \\
901 \\
\end{array}$ & $\begin{array}{r}5,070 \\
- \\
307,665 \\
\end{array}$ & $\begin{array}{r}2 \\
0 \\
2,768 \\
\end{array}$ & $\begin{array}{r}321 \\
73 \\
740,759 \\
\end{array}$ \\
\hline : 計 & 1,107 & 811,320 & 4,104 & $1,106,760$ & 6,478 & $1,844,3$ \\
\hline 鋼 & 399,978 & $64,718,712$ & 229,634 & $35,944,370$ & 263,161 & $29,380,8$ \\
\hline 總 & 504,764 & $71,783,001$ & 255,181 & $37,299,882$ & 289,111 & $30,64,6 \%$ \\
\hline
\end{tabular}


入品種 別 表

二)

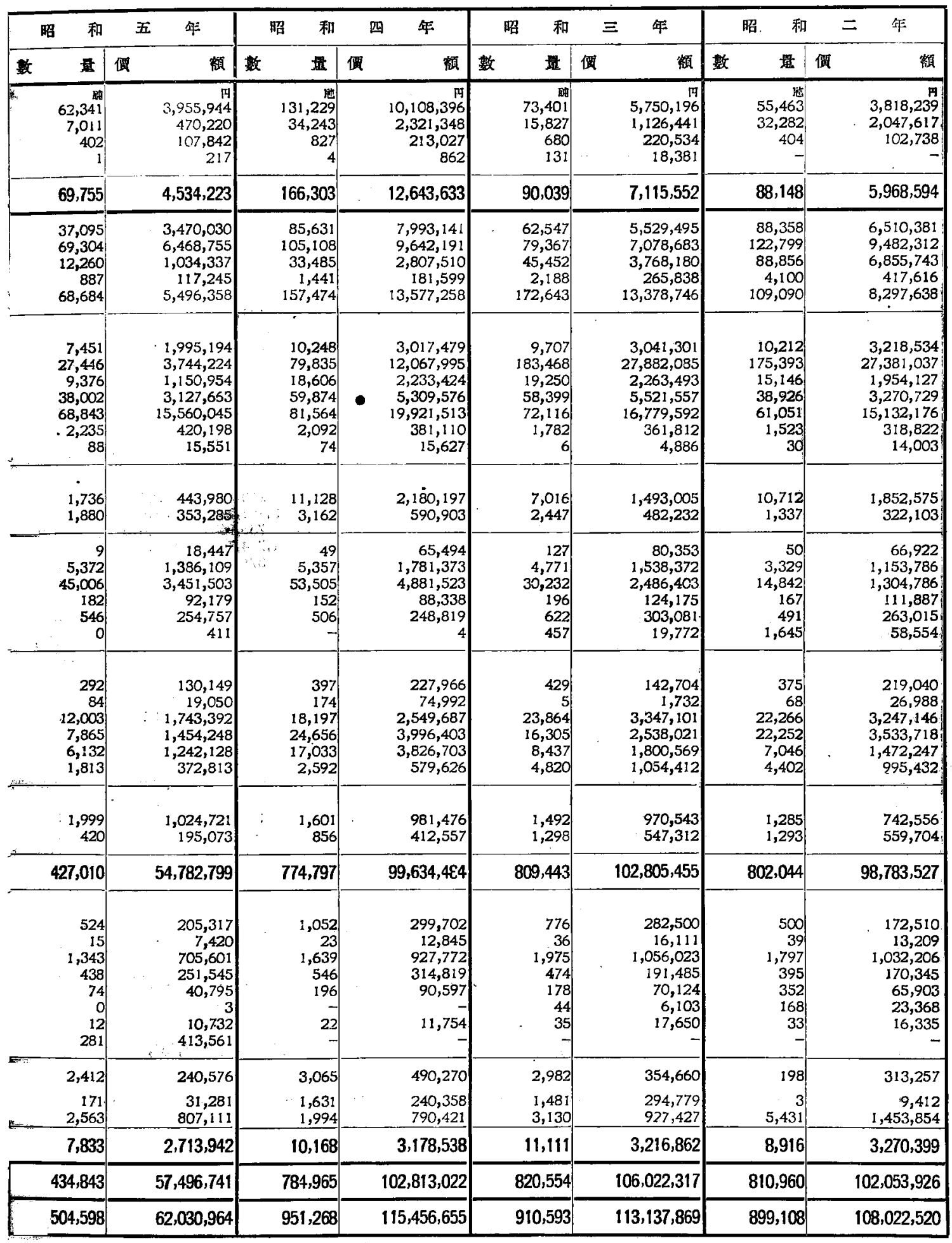




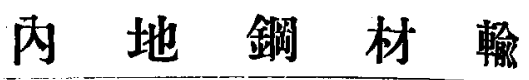

(其

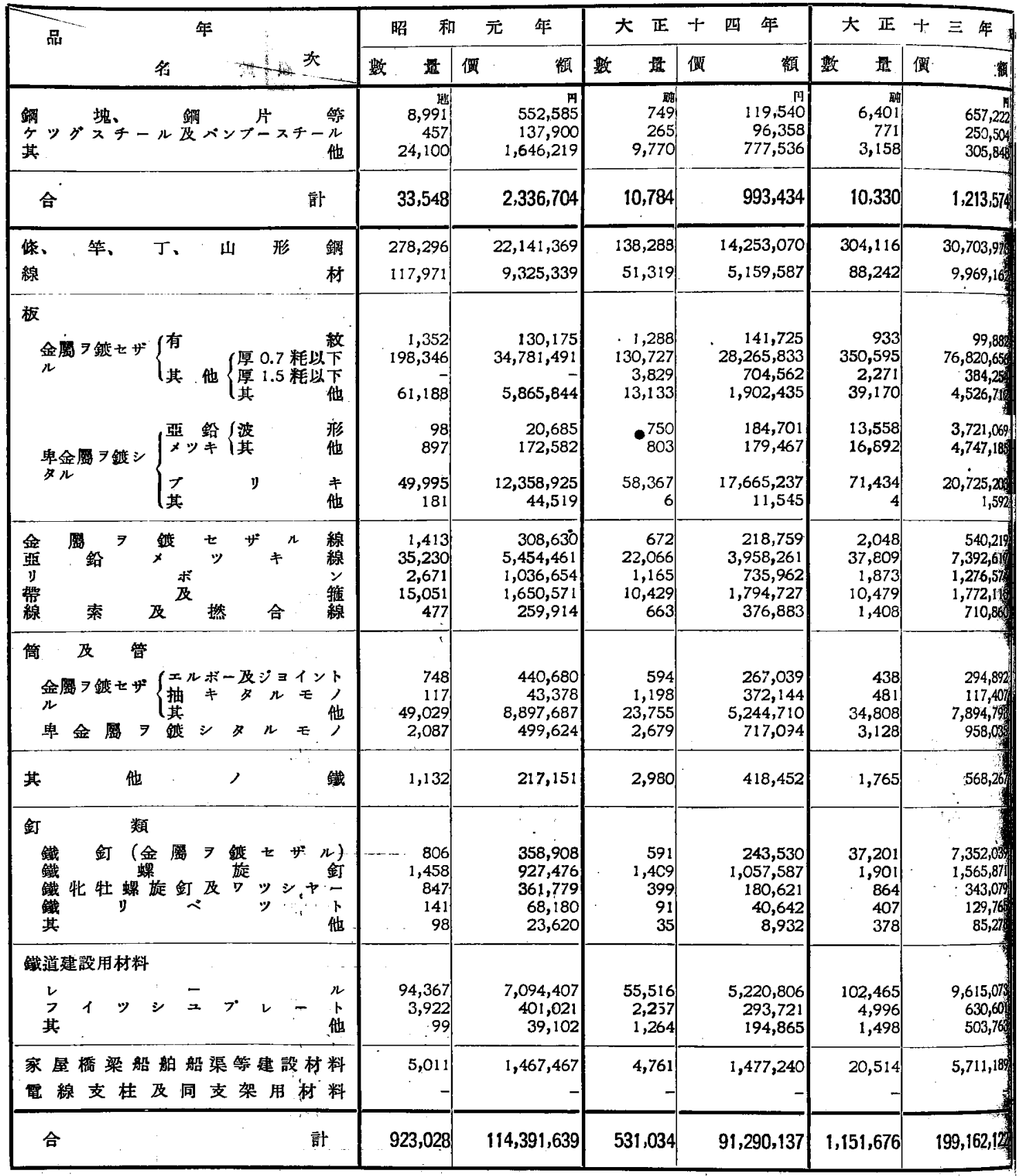

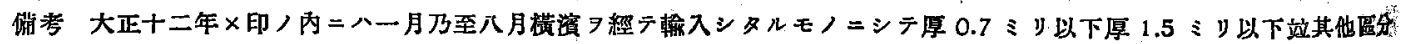




\section{入品種 別表}

\section{三)}

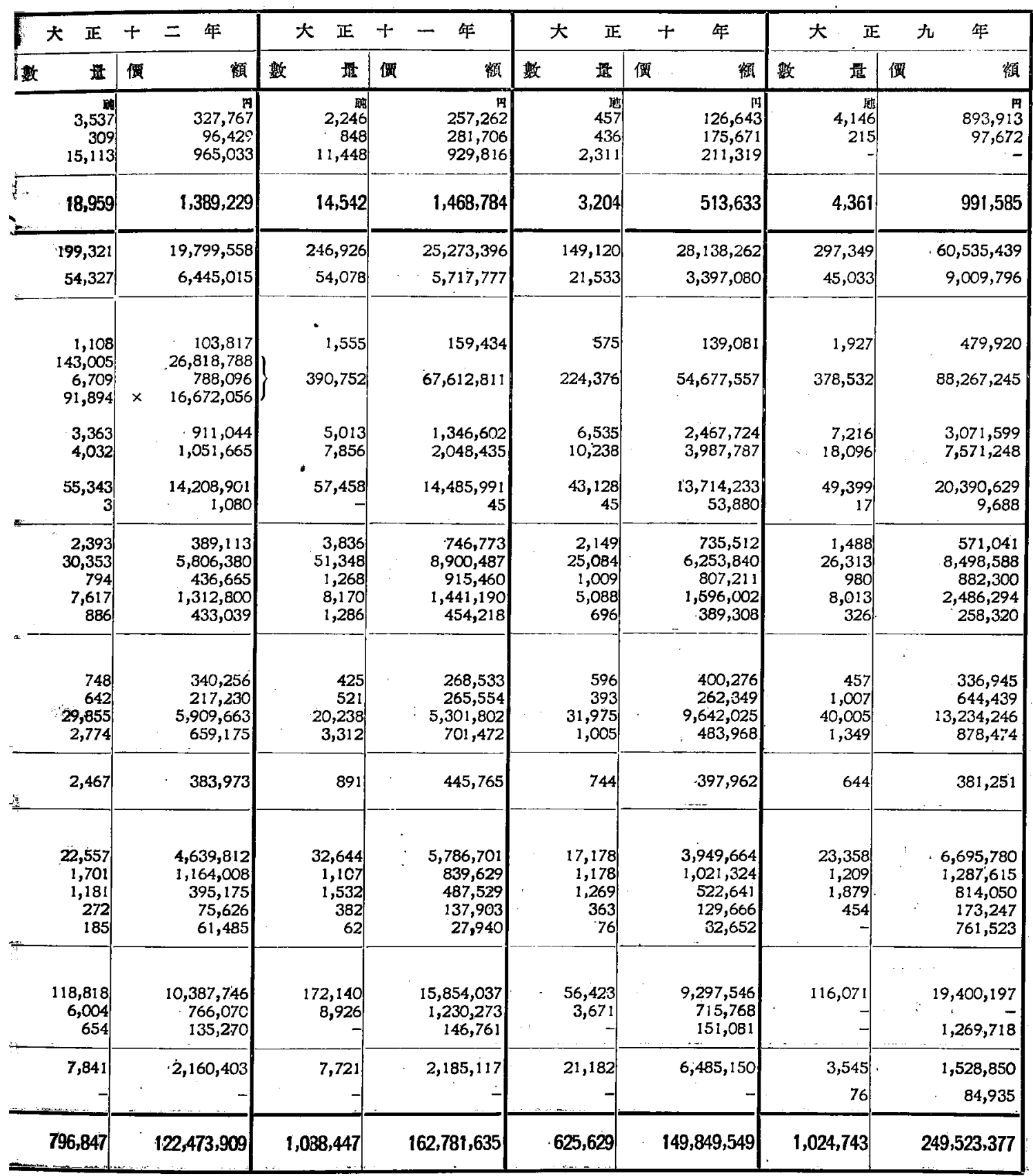

不明ナルモノノ数共 64,371殉其，洒額 10,912,151圆 7 含么 
內 地鋼 材 輸

(筫

\begin{tabular}{|c|c|c|c|c|c|c|}
\hline 年 & 大 & 年 & 大 & t & 大 & 宍 \\
\hline 名广次 & 教 & 価 & 数 & 傎 & 数 & 便 \\
\hline 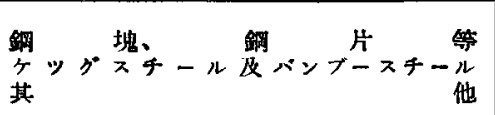 & 11,802 & $\begin{array}{r}\text { Pि| } \\
4,252,554 \\
4,629 \\
103\end{array}$ & $\begin{array}{r}\text { ren } \\
9,269 \\
- \\
-\end{array}$ & \begin{tabular}{r|} 
円 \\
$4,348,445$ \\
1,532 \\
1,214
\end{tabular} & \begin{tabular}{r|r|}
1,993 \\
2 \\
21
\end{tabular} & $\begin{array}{r}715,008 \\
752 \\
2,102 \\
\end{array}$ \\
\hline 合計 & 11,803 & $4,257,286$ & 9,269 & $4,351,191$ & 2,016 & 517,862 \\
\hline $\begin{array}{lllll}\text { 條、等、 ゴ、山 形銅 } \\
\text { 線 }\end{array}$ & $\begin{array}{r}190,926 \\
37,696\end{array}$ & $\begin{array}{r}47,721,390 \\
9,990,551\end{array}$ & $\begin{array}{r}265,791 \\
33,987\end{array}$ & $\begin{array}{r}84,221,802 \\
8,794,449\end{array}$ & $\begin{array}{r}197,639 \\
25,374\end{array}$ & $\begin{array}{r}46,369,428 \\
6,930,644\end{array}$ \\
\hline $\begin{array}{l}\text { 板 } \\
\text { 金筑 } \text { 鍍セザ }\end{array}$ & $\begin{array}{r}1,615 \\
239,589 \\
\\
1,076 \\
3,553 \\
37,336 \\
28\end{array}$ & $\begin{array}{r}627,292 \\
67,854,935 \\
\\
424,621 \\
1,452,447 \\
17,515,565 \\
19,198\end{array}$ & $\begin{array}{r}564 \\
160,138 \\
\\
850 \\
1,431 \\
29,319 \\
22\end{array}$ & $\begin{array}{r}477,348 \\
77,932,198 \\
\\
371,993 \\
760,165 \\
\\
20,836,713 \\
10,179\end{array}$ & $\begin{array}{r}1,105 \\
298,086 \\
\\
2,606 \\
1,713 \\
26,848 \\
250\end{array}$ & $\begin{array}{r}319,994 \\
91,395,551 \\
825,158 \\
581,56 \% \\
11,725,622 \\
120,489\end{array}$ \\
\hline 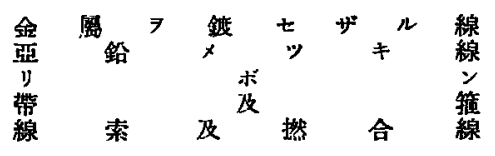 & $\begin{array}{r}3,069 \\
24,965 \\
994 \\
5,421 \\
232 \\
\end{array}$ & $\begin{array}{r}1,180,818 \\
7,796,850 \\
891,556 \\
2,093,987 \\
208,063\end{array}$ & $\begin{array}{r}5,791 \\
21,173 \\
789 \\
4,349 \\
72\end{array}$ & $\begin{array}{r}1,906,530 \\
7,560,156 \\
863,076 \\
1,901,799 \\
42,802\end{array}$ & $\begin{array}{r}4,408 \\
18,560 \\
394 \\
4,079 \\
363\end{array}$ & $\begin{array}{r}1,303,054 \\
5,858,75 \\
242,284 \\
1,243,16 \\
170,218\end{array}$ \\
\hline 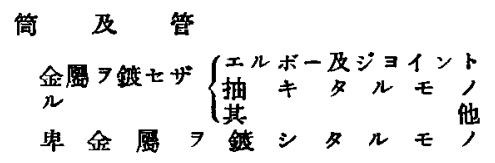 & $\begin{array}{r}243 \\
713 \\
30,066 \\
584\end{array}$ & $\begin{array}{r}207,355 \\
698,996 \\
11,804,174 \\
465,069\end{array}$ & $\begin{array}{r}146 \\
104 \\
33,469 \\
814\end{array}$ & $\begin{array}{r}97,922 \\
81,506 \\
13,205,183 \\
384,960\end{array}$ & $\begin{array}{r}177 \\
92 \\
26,063 \\
834\end{array}$ & $\begin{array}{r}88,336 \\
90,721 \\
8,298,958 \\
327,890\end{array}$ \\
\hline 其他少鐵 & 315 & 278,405 & 435 & 391,936 & 329 & 197,807 \\
\hline 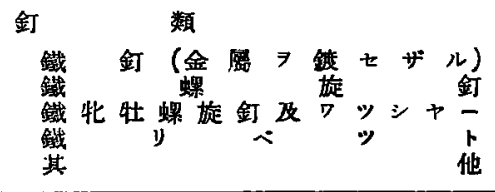 & $\begin{array}{r}16,306 \\
1,307 \\
2,366 \\
419 \\
-\end{array}$ & $\begin{array}{r}5,125,072 \\
1,390,550 \\
1,139,415 \\
243,794 \\
755,411\end{array}$ & $\begin{array}{r}16,453 \\
1,009 \\
3,261 \\
809 \\
-\end{array}$ & $\begin{array}{r}5,309,536 \\
962,444 \\
1,548,768 \\
450,221 \\
337,750\end{array}$ & $\begin{array}{r}9,432 \\
1,010 \\
597 \\
546 \\
-\end{array}$ & $\begin{array}{r}2,530,252 \\
696,871 \\
233,320 \\
262,950 \\
260,20\end{array}$ \\
\hline 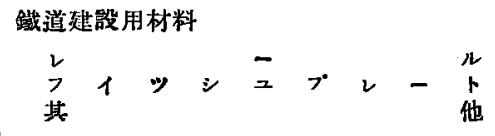 & $\begin{array}{r}121,299 \\
-\end{array}$ & $\begin{array}{r}21,866,848 \\
- \\
1,598,974\end{array}$ & $\begin{array}{r}67,773 \\
- \\
-\end{array}$ & $\begin{array}{r}14,941,164 \\
895,468\end{array}$ & $\begin{array}{r}51,077 \\
2,020 \\
-7\end{array}$ & $\begin{array}{r}8,114,151 \\
431,738 \\
447,859\end{array}$ \\
\hline $\begin{array}{l}\text { 家屋橋梁船舶船渠等建設材料 } \\
\text { 管線支杜及同势架用材料 }\end{array}$ & $\begin{array}{r}1,330 \\
383\end{array}$ & $\begin{array}{l}610,844 \\
151,986\end{array}$ & $\begin{array}{r}2,465 \\
14\end{array}$ & $\begin{array}{r}956,778 \\
16,385\end{array}$ & $\begin{array}{r}1,101 \\
34\end{array}$ & $\begin{array}{r}365,90 \% \\
9,03 \%\end{array}$ \\
\hline 31 & $: 721,831$ & $204,114,166$ & 651,028 & $245,259,231$ & 674,737 & $189,441,912$ \\
\hline
\end{tabular}




\section{入品 種 別 表}

四）

\begin{tabular}{|c|c|c|c|c|c|c|c|c|c|}
\hline 大 正 & 五 年 & 大 正 & 年 & 大 IE & 三 年 & 大 正 & 二 年 & 大 正 & 元 年 \\
\hline 易 & 頖 & 㙁 & 霓 & 数 & 制 & 数 贯 & 锁 & 政 徥 & 曋 \\
\hline \begin{tabular}{r|}
7,065 \\
377 \\
30
\end{tabular} & $\begin{array}{r}\text { 四 } \\
1,522,465 \\
67,193 \\
2,600\end{array}$ & $\begin{array}{r}2,331 \\
258 \\
-\end{array}$ & $\begin{array}{r}\text { m } \\
327,707 \\
35,652 \\
-\end{array}$ & $\begin{array}{r}7,157 \\
775 \\
2\end{array}$ & $\begin{array}{r}14 \\
890,971 \\
104,961 \\
1,231\end{array}$ & 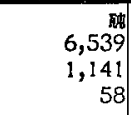 & $\begin{array}{r}\mathrm{P} \\
861,340 \\
146,789 \\
8,369\end{array}$ & $\begin{array}{r}\text { 㽢 } \\
-1,172 \\
8,686\end{array}$ & $\begin{array}{r}\text { म } \\
- \\
147,788 \\
952,510\end{array}$ \\
\hline 7,472 & $1,592,258$ & 2,589 & 363,359 & 7,934 & 997,163 & 7,738 & $1,016,498$ & 9,858 & $1,100,298$ \\
\hline 143,658 & - $22,507,892$ & 58,622 & $5,601,838$ & I 54,749 & $9,866,280$ & 185,207 & $13,840,079$ & 220,175 & $15,392,270$ \\
\hline 18,900 & $4,076,082$ & 10,005 & $1,080,749$ & 3,457 & 412,306 & 4,595 & 567,552 & 2,531 & 317,354 \\
\hline 759 & 122,799 & 403 & 46,349 & 862 & 53,309 & 997 & 71,540 & 1,410 & 109,576 \\
\hline 160,400 & $22,619,249$ & 77,787 & $7,733,155$ & 88,176 & $6,942,091$ & 94,052 & $8,620,850$ & 111,057 & $9,449,545$ \\
\hline $\begin{array}{r}2,579 \\
2,301\end{array}$ & $\begin{array}{l}596,190 \\
562,373\end{array}$ & $\begin{array}{l}2,617 \\
4,7 ! 0\end{array}$ & $\begin{array}{l}432,082 \\
792,412\end{array}$ & $\begin{array}{r}8,115 \\
11,719\end{array}$ & $\begin{array}{l}1,131,459 \\
1,828,627\end{array}$ & $\begin{array}{l}14,587 \\
19,709\end{array}$ & $\begin{array}{l}2,221,070 \\
3,160,086\end{array}$ & $\begin{array}{l}15,620 \\
37,057\end{array}$ & $\begin{array}{l}2,285,172 \\
5,808,760\end{array}$ \\
\hline $\begin{array}{r}39,305 \\
r, 401\end{array}$ & $\begin{array}{r}10,083,698 \\
459,471\end{array}$ & $\begin{array}{r}29,707 \\
870\end{array}$ & $\begin{array}{r}4,792,181 \\
236,360\end{array}$ & 26,119 & $\begin{array}{r}4,010,274 \\
11,396\end{array}$ & $\begin{array}{r}26,486 \\
31\end{array}$ & $\begin{array}{r}4,603,305 \\
5,096\end{array}$ & $\begin{array}{r}25,715 \\
18\end{array}$ & $\begin{array}{r}4,274,498 \\
3,025\end{array}$ \\
\hline $\begin{array}{r}2,865 \\
18,460 \\
1,090 \\
-\quad 3,084 \\
455\end{array}$ & $\begin{array}{r}625,998 \\
4,324,365 \\
579,342 \\
594,116 \\
183,339\end{array}$ & $\begin{array}{r}2,712 \\
21,986 \\
700 \\
1,300 \\
368\end{array}$ & $\begin{array}{r}383,269 \\
3,175,377 \\
247,670 \\
159,018 \\
119,275\end{array}$ & $\begin{array}{r}2,671 \\
20,521 \\
833 \\
3,487 \\
1,185\end{array}$ & $\begin{array}{r}282,651 \\
2,127,642 \\
242,410 \\
300,538 \\
368,585\end{array}$ & $\begin{array}{r}5,121 \\
22,603 \\
1,413 \\
3,053 \\
1,427\end{array}$ & $\begin{array}{r}572,036 \\
2,447,193 \\
395,869 \\
295,280 \\
406,636\end{array}$ & $\begin{array}{r}4,904 \\
33,169 \\
957 \\
3,484 \\
1,527\end{array}$ & $\begin{array}{r}522,765 \\
3,499,299 \\
260,271 \\
229,530 \\
451,515\end{array}$ \\
\hline $\begin{array}{r}92 \\
124\end{array}$ & $\begin{array}{l}32,943 \\
74,708\end{array}$ & $\begin{array}{l}118 \\
190\end{array}$ & $\begin{array}{l}31,922 \\
63,482\end{array}$ & $\begin{array}{l}444 \\
533\end{array}$ & $\begin{array}{l}148,301 \\
173,435\end{array}$ & $\begin{array}{l}987 \\
933\end{array}$ & $\begin{array}{l}300,974 \\
256,361\end{array}$ & $\begin{array}{l}1,515 \\
1,267\end{array}$ & $\begin{array}{l}390,329 \\
320,805\end{array}$ \\
\hline $\begin{array}{r}15,878 \\
760\end{array}$ & $\begin{array}{r}3,080,723 \\
246,170\end{array}$ & $\begin{array}{r}8,147 \\
613\end{array}$ & $\begin{array}{r}1,148,954 \\
135,789\end{array}$ & 28,403 & $3,808,330$ & 43,641 & $6,376,555$ & 33,209 & $4,251,588$ \\
\hline 417 & 144,798 & 291 & 89,935 & 270 & 69,562 & 260 & 66,336 & 258 & 80,287 \\
\hline $\begin{array}{r}21,388 \\
848 \\
479 \\
697 \\
-\end{array}$ & $\begin{array}{r}4,202,521 \\
432,928 \\
185,620 \\
179,290 \\
43,969\end{array}$ & $\begin{array}{r}3,510 \\
584 \\
302 \\
210 \\
-\end{array}$ & $\begin{array}{r}537,864 \\
220,059 \\
78,858 \\
46,657 \\
75,167\end{array}$ & $\begin{array}{r}5,230 \\
739 \\
1,408 \\
512\end{array}$ & $\begin{array}{r}508,258 \\
246,945 \\
280,785 \\
71,099 \\
165,780\end{array}$ & $\begin{array}{r}13,657 \\
487 \\
2,503 \\
847\end{array}$ & $\begin{array}{r}1,370,404 \\
192,862 \\
461,593 \\
125,271 \\
247,969\end{array}$ & $\begin{array}{r}37,888 \\
1,172 \\
3,742 \\
1,583 \\
-\end{array}$ & $\begin{array}{r}3,449,502 \\
413,749 \\
618,087 \\
200,958 \\
254,840\end{array}$ \\
\hline $\begin{array}{r}4,379 \\
179\end{array}$ & $\begin{array}{r}440,883 \\
31,855 \\
43,969\end{array}$ & $\begin{array}{r}8,992 \\
267 \\
-\end{array}$ & $\begin{array}{r}603,382 \\
23,941 \\
6,742\end{array}$ & $\begin{array}{r}27,715 \\
836 \\
-\end{array}$ & $\begin{array}{r}1,878,624 \\
72,101 \\
74,610\end{array}$ & $\begin{array}{r}60,764 \\
2,583\end{array}$ & $\begin{array}{r}4,086,333 \\
227,540 \\
20,087\end{array}$ & $\begin{array}{r}63,456 \\
2,729 \\
-\end{array}$ & $\begin{array}{r}3,939,337 \\
222,455 \\
32,727\end{array}$ \\
\hline 1,666 & 437,113 & 737 & 152,700 & 3,090 & 525,995 & 19,629 & $2,871,501$ & 16,127 & $2,146,837$ \\
\hline 24 & 4,296 & 2 & 1,882 & 4,105 & $612 ; 224$ & 2,035 & 306,028 & 1,364 & 238,661 \\
\hline 442.188 & $76,916,700$ & 235,750 & $28,017,069$ & 395,252 & $36,213,627$ & 527,607 & $54,136,386$ & 621,934 & $59,163,742$ \\
\hline
\end{tabular}


内地

鐵

（其

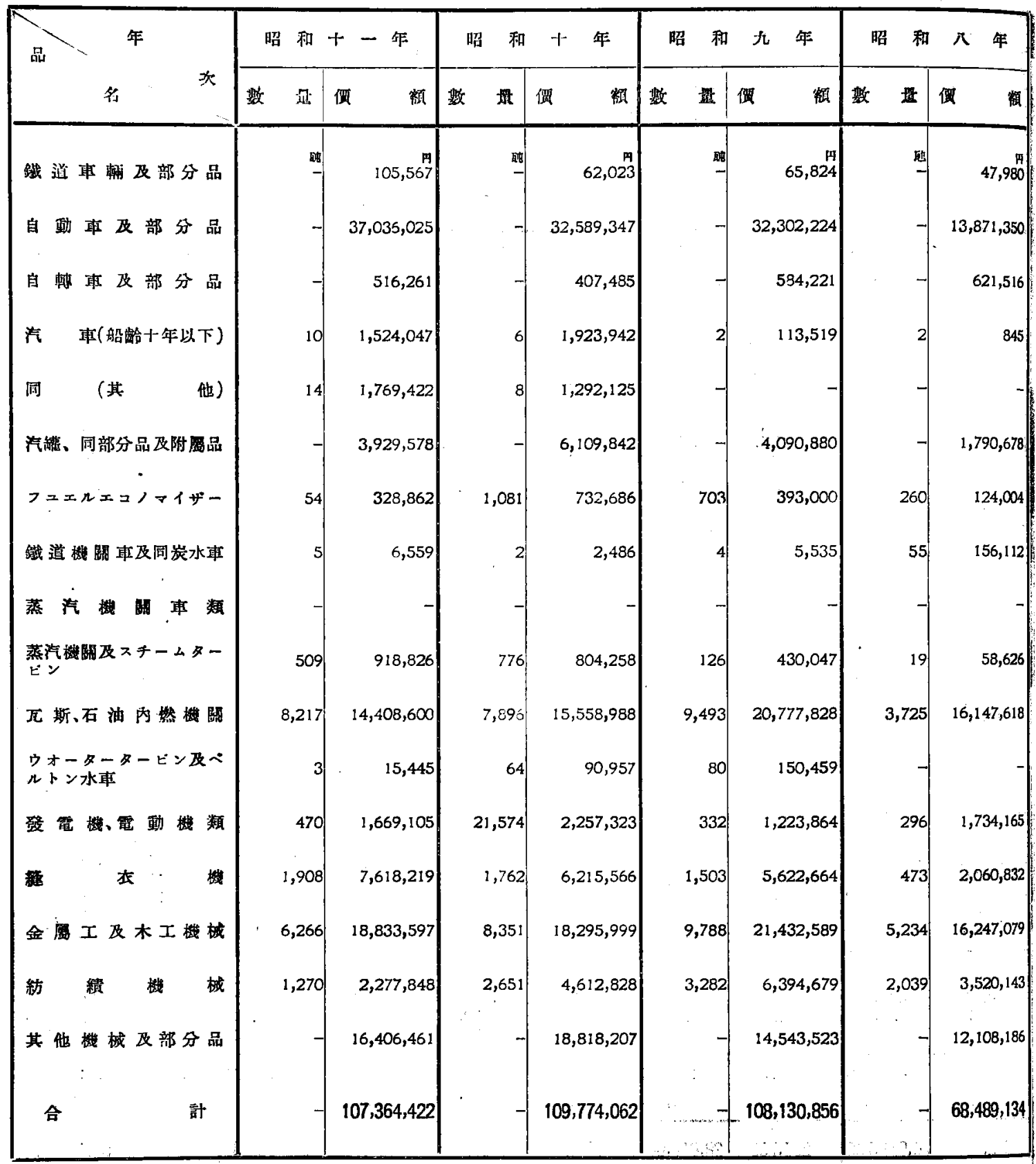

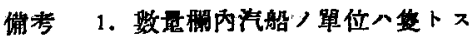

2. 昭和二年以降/汽船八船龄二十年以下ト 


\section{製 品 輸入表}

-)

\begin{tabular}{|c|c|c|c|c|c|c|c|c|c|c|c|}
\hline 昭 和 & 七 年 & 昭 和 & 六 年 & 昭 & 年 & 昭 & 四 年 & 昭 & 三 年 & 昭．和 & $=$ \\
\hline 数 显 & 洒 & 蜘 塭 & 偩 額 & 数 曻 & 㑔 & 数 露 & 俩 & 数 恶 & 熘 & 数 福 & 僄 \\
\hline 䏛 & $\begin{array}{r}\text { M } \\
74,347\end{array}$ & - & $\begin{array}{r}\text { 的 } \\
132,856\end{array}$ & 则 & 324,218 & 明 & $1,420,673$ & 酎 & $2,091,839$ & $\stackrel{\text { 漚 }}{-}$ & $1,443,9.16$ \\
\hline & $14,821,423$ & - & $16,329,168$ & - & $20,773,730$ & - & $33,608,383$ & - & $32,244,822$ & - & $18,281,971$ \\
\hline- & 795,286 & - & $1,153,545$ & - & $1,563,699$ & - & $2,842,846$ & - & $3,257,429$ & $\therefore$ & $3,527,634$ \\
\hline- & - & 1 & 12,000 & 1 & 73,035 & 8 & $2,478,775$ & 21 & $10,710,177$ & 19 & $4,131,367$ \\
\hline . & - & 2 & 68,360 & 1. & 157,560 & 1 & 200 & 4 & 349,000 & - & - \\
\hline$\because \div \quad$ & $1,192,482$ & - & $2,237,654$ & - & $3,124,470$ & - & $2 ; 376,404$ & -1 & $3,349,590$ & - & $2,818,471$ \\
\hline$\because 129$ & 50,407 & 625 & 267,949 & 370 & 131,551 & 858 & 302,974 & 736 & 293,530 & 1,110 & 466,254 \\
\hline$\because 54$ & 70,397 & 59 & 59,530 & 441 & 544,389 & 847 & $1,062,555$ & 608 & 905,264 & 836 & 927,222 \\
\hline 1139 & 182,291 & 498 & 695,713 & 1,140 & $1,024,989$ & 538 & 825,180 & 145 & 244,598 & 638 & $1,26 \mathrm{~T}, 492$ \\
\hline 4,277 & $12,471,317$ & 5,625 & $10,929,656$ & 10,338 & $14,476,911$ & 11,975 & $18,113,303$ & 7,089 & $12,842,277$ & 4,073 & $5,090,732$ \\
\hline 2 & 9,081 & $\therefore-$ & - & 32 & 36,136 & 1,061 & $1,095,931$ & 520 & 559,205 & 496 & 517, or 1 \\
\hline 250 & $1,643,969$ & 944 & $1,999,408$ & 1,827 & $3,538,611$ & 4,631 & $6,832,409$ & 3,725 & $6,416,372$ & 5,079 & $7,030,207$ \\
\hline 860 & $3,106,274$ & 1,190 & $2,627,981$ & 1,787 & $3,940,018$ & 3,783 & $9,220,086$ & 2,096 & $5,242,884$ & 2,594 & $6,583,263$ \\
\hline 1,734 & $5,808,181$ & 1,702 & $3,070,106$ & 2,550 & $4,841,017$ & 3,656 & $5,624,385$ & 2,327 & $4,381,878$ & 4,433 & $4,985,827$ \\
\hline 8,419 & $7,998,254$ & 4,575 & $3,512,433$ & 8,630 & $6,365,232$ & 16,632 & $14,486,612$ & - & $10,431,087$ & 9,376 & $10 ; 204,753$ \\
\hline & $8,909,341$ & - & $6,937,279$ & - & $11,180,394$ & & $15,983,275$ & - & $19,190,058$ & & $15,016,926$ \\
\hline$i$ & $57,133,050$ & - & $50,033,638$ & -1 & $72 ; 095 ; 960$ & & $116,272,991$ & -1 & $112,510,010$ & - & $82,287,046$ \\
\hline
\end{tabular}


内地

(其

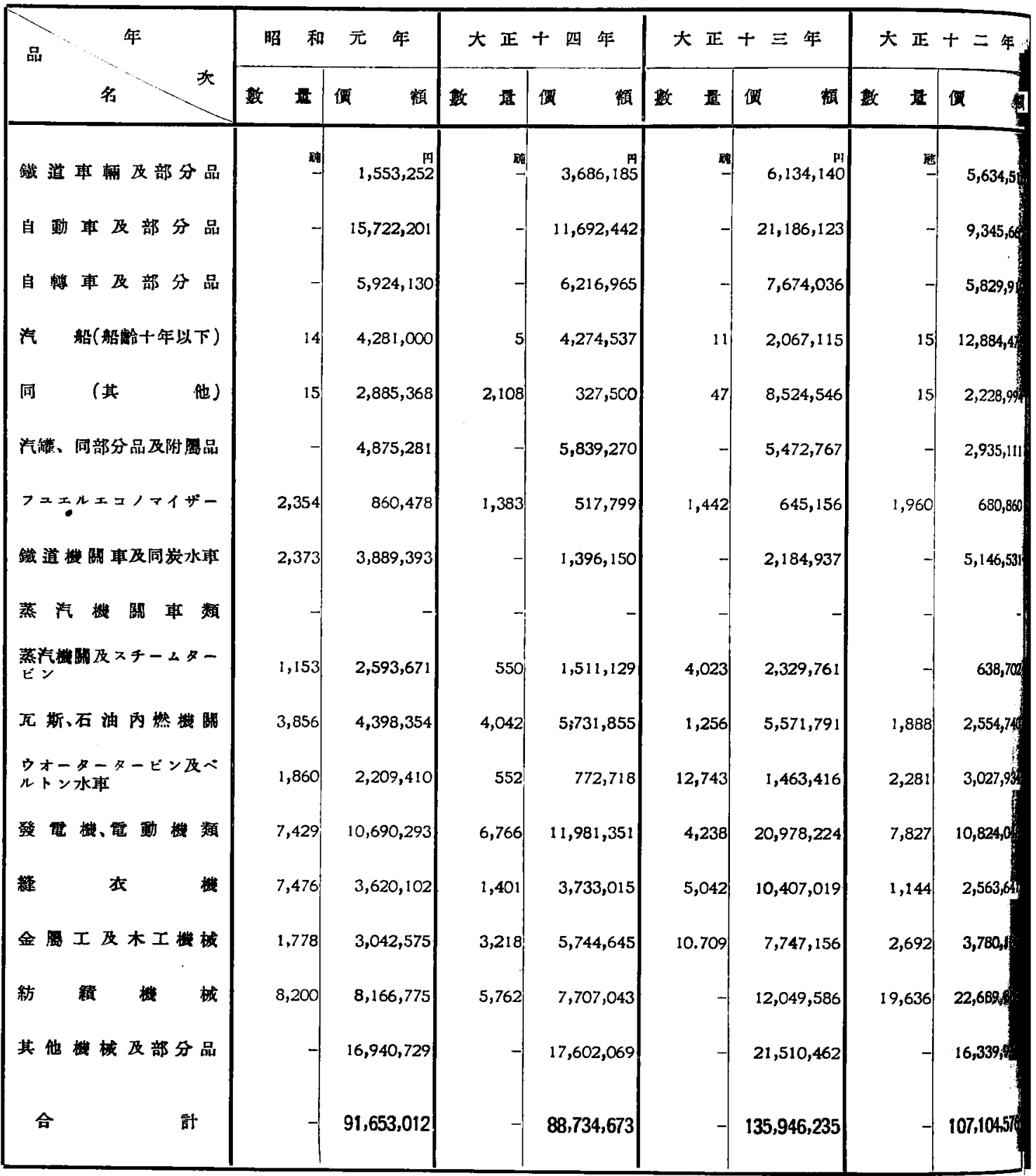




\section{製 品 輸 入 表}

二)

\begin{tabular}{|c|c|c|c|c|c|c|c|c|c|c|c|}
\hline \multicolumn{2}{|c|}{ 大正十一年 } & \multicolumn{2}{|c|}{ 大 正 十 年 } & \multicolumn{2}{|c|}{ 大 正 九 年 } & \multicolumn{2}{|c|}{ 大 正 八 年 } & \multicolumn{2}{|c|}{ 大 正 七 年 } & \multicolumn{2}{|c|}{ 大 正 六 年 } \\
\hline 数量 & 價 額 & 數 哑 & 僄殥 & 数 墥 & 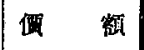 & 数 垭 & 俩 鹤 & 数 堪 & 鼬 & 龉 䭪 & 俩 \\
\hline 政 & $2,701,516^{中}$ & 胡 & $\underset{5,255,174}{\text { P }}$ & 䃑 & $7,117,372$ & 殐 & $6,782,674$ & 酗 & $3,097,127^{\mathbf{m}}$ & 研 & $\underset{2,2: 9,273}{\mathrm{M}}$ \\
\hline- & $6,309,835$ & - & $8,067,540$ & - & $10,478,756$ & - & $-11,282,301$ & - & $7,672,569$ & - & $2,667,601$ \\
\hline- & $6,477,321$ & - & $6,411,396$ & - & $6,719,923$ & - & $2,579,551$ & - & $1,499,878$ & - & 709,812 \\
\hline 6 & $1,397,750$ & 1 & 450 & 2 & 178,000 & 9 & 117,500 & 7 & 551,160 & 5 & 213,000 \\
\hline 12 & $2,532,623$ & .2 & 262,000 & I & 85,000 & 6 & 351,075 & 14 & $2,897,355$ & 17 & $6,679,661$ \\
\hline- & $6,402,695$ & - & $7,605,623$ & - & $6,680,337$ & - & $8,335,958$ & - & $7,466,103$ & - & $2,711,613$ \\
\hline 2,364 & 932,109 & 3,433 & $1,510,830$ & 1,518 & 613,688 & 751 & 272,351 & 471 & 131,422 & 873 & 171,890 \\
\hline- & $1,446,136$ & - & $1,910,081$ & - & 914,738 & - & 408,628 & - & 398,397 & -1 & 111,969 \\
\hline- & & - & - & 165 & 180,810 & $3 i$ & 23,945 & 11 & 7,502 & - & - \\
\hline- & $1,172,494$ & - & $2,683,342$ & - & $2,193,516$ & 802 & $1,367,828$ & 318 & 737,670 & - & 563,384 \\
\hline 1,921 & $2,370,799$ & 480 & $1,111,336$ & 1,061 & $4,771,267$ & 229 & 966,374 & 333 & 492,907 & 118 & 262,804 \\
\hline 1,797 & $2,978,986$ & 1,137 & $1,600,301$ & 457 & 779,152 & 948 & $1,787,733$ & 66 & 82,324 & 363 & 305,646 \\
\hline 7,059 & $11,947,498$ & 4,762 & $9,664,446$ & 3,323 & $6,080,114$ & 2,738 & $5,245,443$ & 1,837 & $2,977,278$ & 865 & $1,129,644$ \\
\hline 2,027 & $4,176,528$ & 1,574 & $3,169,997$ & 3,161 & $6,321,872$ & 2,590 & $4,765,061$ & 1,816 & $2,948,732$ & 723 & $1,001,533$ \\
\hline 4,110 & $6,521,357$ & 7,159 & $10,976,988$ & 8,687 & $13,650,737$ & 6,145 & $10,563,324$ & 5,165 & $6,553,210$ & $3 ; 744$ & $3,452,183$ \\
\hline 25,489 & $30,596,030$ & 30,946 & $29,180,085$ & 18,353 & $18,163,921$ & 13,026 & $13,864,157$ & 10,844 & $8,545,732$ & 8,748 & $4,791,486$ \\
\hline & $16,379,703$ & - & $17,499,499$ & - & $17,199,730$ & - & $12,243,458$ & - & $22,980,095$ & - & $13,770,577$ \\
\hline & $104,343,380$ & & $106,909,088$ & & $102,123,933$ & - & $80,957,361$ & - & $69,039,461$ & - & $40,762,076$ \\
\hline
\end{tabular}


内地鐵鋼製品签入表

（其 三）

\begin{tabular}{|c|c|c|c|c|c|c|c|c|c|c|}
\hline \multirow{2}{*}{ 品 } & \multicolumn{2}{|c|}{ 大 正 五 年 } & \multicolumn{2}{|c|}{ 大 正 四 年 } & \multicolumn{2}{|c|}{ 大 正 三 年 } & \multicolumn{2}{|c|}{ 大 正 二 年 } & \multicolumn{2}{|c|}{ 大 正 元 年 } \\
\hline & 数惯 & 偳 & 效理 & 額 & 数植 & 溉 & 数 量 & 洒 & 數量 & 偶 \\
\hline 幽道車輛及部分品 & & 298,975 & at & 619,101 & & $=1,981,40 !$ & & $\begin{array}{r}\text { M } \\
2,074,515\end{array}$ & & 3,131 \\
\hline 自動車及部 分品 & - & 713,485 & - & 165,265 & - & 498,412 & - & $1,110,044$ & - & 894 \\
\hline 自轉束及部分品 & - & 477,914 & - & 313,002 & & $1,035,094$ & - & $2,134,281$ & - & $2,002,88$ \\
\hline 汽船(船柃十年以下) & 2 & 229,030 & 3 & $1,882,826$ & 7 & $2,230,197$ & 5 & $1,793,415$ & 12 & 2,383 \\
\hline 同 （其 他） & 13 & $10,585,519$ & 7 & 752,038 & 6 & $: 612,473$ & 15 & $2,207,194$ & 13 & $1,565,51$ \\
\hline 汽鑵、同部分品及附風品 & - & $1,367,147$ & - & 570,071 & & 860,851 & - & 976,341 & & $1,174,71$ \\
\hline フニエルエコノマイザー & 552 & 119,004 & 421 & 61,915 & 598 & 84,472 & 947 & 146,263 & 626 & 84,44 \\
\hline 幽道㯊 & - & 120,544 & - & 228,335 & - & 447,476 & - & $2,386,710$ & - & 801, \\
\hline 丞 汽 機 距 車 類 & 1.1 & 6,010 & 19 & 8,933 & 43 & 25,060 & 82 & 34,664 & 89 & 32,90 \\
\hline 丞汽機戌及スチームター & - & 261,864 & - & 78,282 & - & 615,892 & - & 633,015 & - & 524,104 \\
\hline 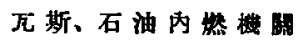 & 164 & 179,908 & 142 & 163,194 & 485 & 365,659 & 1,968 & $1,261,252$ & 5,295 & $1,390,198$ \\
\hline $\begin{array}{l}\text { ウオータータービン及べ } \\
\text { ルトン水車 }\end{array}$ & 124 & 115,245 & 139 & 116,360 & 539 & 321,745 & 1,347 & 728,872 & 1,607 & 808,804 \\
\hline 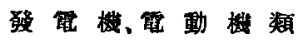 & 305 & 391,958 & 587 & 501,406 & 3,301 & $2,407,634$ & 5,352 & $3,659,130$ & 5,028 & $3,198,555$ \\
\hline 衣 & 492 & 790,079 & 225 & 243,156 & 162 & 219,486 & 878 & 809,910 & 1,228 & $1,210,406$ \\
\hline 给感工及木エ棤械 & 1,499 & $1,783,414$ & 1,434 & 890,918 & 4,555 & $2,480,628$ & 5,971 & $3,279,026$ & 7,559 & $3,966,421$ \\
\hline 紡． 綪 & 3,920 & $2,408,542$ & 2,755 & $1,335,579$ & 12,449 & $5,332,391$ & 13,708 & $5,069,793$ & 4,306 & $1,802,555$ \\
\hline 其他機柀及部分品 & & $7,719,361$ & - & $4,097,906$ & & $10,792,698$ & - & $16,807,807$ & - & $13,549,753$ \\
\hline 合 & & $27,567,699$ & & $12,028,287$ & & $30,311,580$ & & $45,111,732$ & $\cdots$ & $38,522,85$ \\
\hline
\end{tabular}




\section{鐵 鋼 材 輸 出 表}

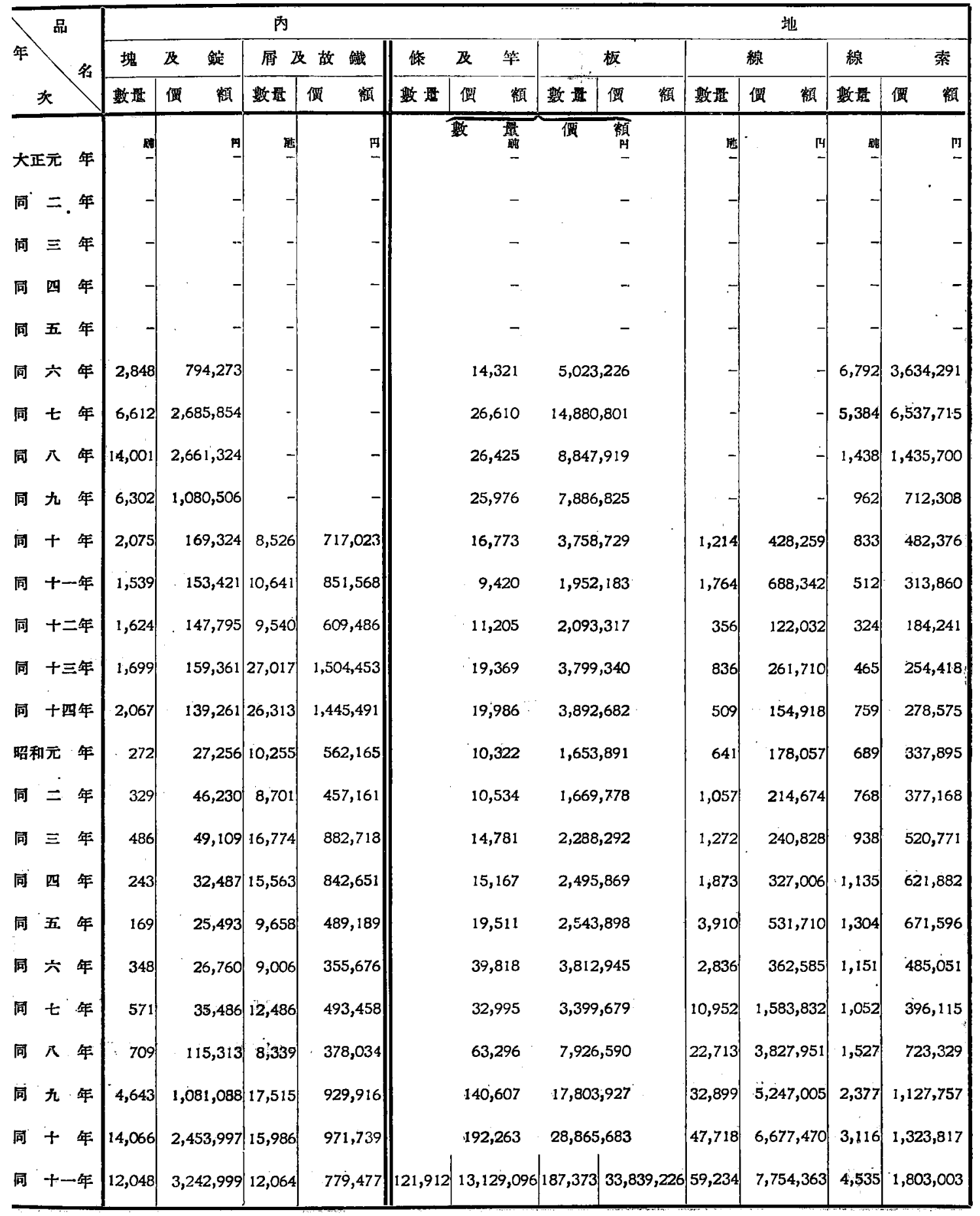




\begin{tabular}{|c|c|c|c|c|c|c|c|c|c|c|c|c|c|c|c|}
\hline \multirow{3}{*}{\multicolumn{3}{|c|}{$\begin{array}{c}\text { 年 } \\
\text { 次 }\end{array}$}} & \multicolumn{4}{|c|}{ 内 } & \multicolumn{9}{|c|}{ 地 } \\
\hline & & & 简 & 及 筞 & 釬 & \multirow{2}{*}{$\frac{\text { 類 }}{\text { 頖 }}$} & \multirow{2}{*}{ 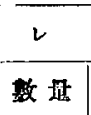 } & - & \multicolumn{3}{|c|}{ 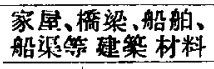 } & 其 & \multirow{2}{*}{$\frac{\text { 他 }}{\text { 頖 }}$} & \multicolumn{2}{|l|}{ 合 } \\
\hline & & & 敏典 & 愘 & 數是 & & & 罢 & 数姆 & 摆 & 額 & 數堤 & & 数最 & 價 \\
\hline 大I & E元 & 年 & 1,210 & 107,000 & 虽 & $\mathbf{A H}$ & 知 & 円 & - & & I & 5,489 & 178,000 & 6,699 & 285,00 \\
\hline & 二 & 年 & 628 & $67, \infty 00$ & - & $\therefore$ & - & - & - & & - & 9,092 & 331,000 & 9,720 & 398,000 \\
\hline & $\equiv$ & 年 & 385 & 48,000 & -1 & -1 & - & - & - & & & 9,607 & 323,000 & 9,992 & 371,000 \\
\hline 同 & 四 & 年 & 1,434 & 198,924 & - & - & - & & - & & & 6,392 & 253,029 & 7,826 & 451,98 \\
\hline 阁 & $\pi$ & 年 & 4,510 & 930,421 & -1 & - & - & - & - & & - & 4,177 & 355,442 & 8,687 & $1,285,8$ \\
\hline & 六 & 年 & $8,43 !$ & $2,039,757$ & - & - & - & - & - & & 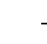 & 3,986 & $1,158,434$ & 33,530 & $11,855,7 x$ \\
\hline 同 & $t$ & 年 & 4,156 & $2,991,304$ & - & - & - & - & - & & - & 4,774 & $2,062,245$ & 40,924 & $26,472,006$ \\
\hline 同 & $\pi$ & 年 & 7,516 & $3,008,3 ! 1$ & - & - & - & - & - & & - & 19,866 & $3,035,120$ & 55,245 & 16,327 \\
\hline 同 & 九 & 年 & 4,828 & $1,915,269$ & - & - & - & - & - & & - & 10,265 & $1,858,416$ & 42,031 & $12,372,8$ \\
\hline 同 & 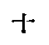 & 年 & 3,949 & $1,164,326$ & - & 613,635 & 1,112 & 349,617 & - & & - & 663 & 91,469 & 24,544 & $6,888,411$ \\
\hline 同 & + & 一年 & 4,539 & 888,074 & - & 575,142 & 1,125 & 168,472 & - & & - & 216 & 45,328 & 17,576 & $4,631,401$ \\
\hline 同 & $+=$ & 二年 & 4,349 & 773,168 & - & 544,504 & 347 & 51,857 & - & & - & 67 & 21,839 & 16,648 & $3,790,958$ \\
\hline 同 & $+\equiv$ & 三年 & 1,947 & 518,095 & - & 919,370 & 2,295 & 264,148 & -1 & & - & 307 & 49,006 & 25,219 & $6,066,087$ \\
\hline 同 & $+R$ & 回年 & 2,979 & 751,055 & - & 753,355 & 9,287 & 969,863 & - & & - & 2,060 & 123,162 & 35,580 & $6,923,610$ \\
\hline 昭和 & & 年 & 2,550 & 666,129 & - & 536,099 & 10,649 & $1,037,243$ & - & & - & 480 & 95,189 & 25,331 & $4,504,50$ \\
\hline 同 & $=$ & 年 & 2,294 & 541,389 & - & 789,028 & 185 & 60,777 & - & & - & 1,090 & 150,840 & 15,928 & 3,80 \\
\hline 同 & & 年 & 3,182 & 792,571 & 2,295 & 567,041 & - & - & - & & - & 415 & 72,352 & 22,883 & 4,48 \\
\hline 同 & 四 & 年 & 3,691 & 805,611 & 2,813 & 694,692 & - & - & - & & - & 822 & 126,727 & 25,501 & 5,0 \\
\hline 同 & 五 & 年 & 6,149 & $1,241,586$ & 4,818 & 797,975 & - & - & - & & - & 32,112 & $3,564,882$ & 67,804 & 9,35 \\
\hline 同 & 六 & 年 & 18,558 & $2,124,797$ & 5,011 & 640,371 & - & - & -1 & & - & 2,113 & 241,991 & 69,487 & 7,66 \\
\hline 同 & $t$ & 年 & 15,053 & $2,023,608$ & 18,999 & $2,486,010$ & - & - & - & & - & 42,503 & $4,346,234$ & 121,554 & 14,2 \\
\hline 同 & 八 & 年 & 29,465 & $4,5: 8,370$ & 25,046 & $4,491,305$ & - & . & - & & & 104,469 & $17,175,997$ & 246,516 & 38,66 ? \\
\hline 同 & 九 & 年 & 49,212 & $9,457,551$ & 36,788 & $6,746,828$ & 95,401 & $16,192,316$ & - & & - & 7,647 & $1,187,6103$ & 364,931 & 57,76 \\
\hline 同 & + & 年 & 43,226 & $9,705,912$ & 36,170 & $6,618,121$ & 100,200 & $13,526,164$ & 10,749 & & & 15,425 & $2,311,1144$ & 448,867 & 71,6 \\
\hline 同 & + & 一年 & 35,444 & $7,582,957$ & 42,443 & $6,935,229$ & 30,010 & $3,467,076$ & 18,524 & & 2,735 & 38,335 & $4,821,9545$ & 537,810 & 82 \\
\hline
\end{tabular}


輸出表

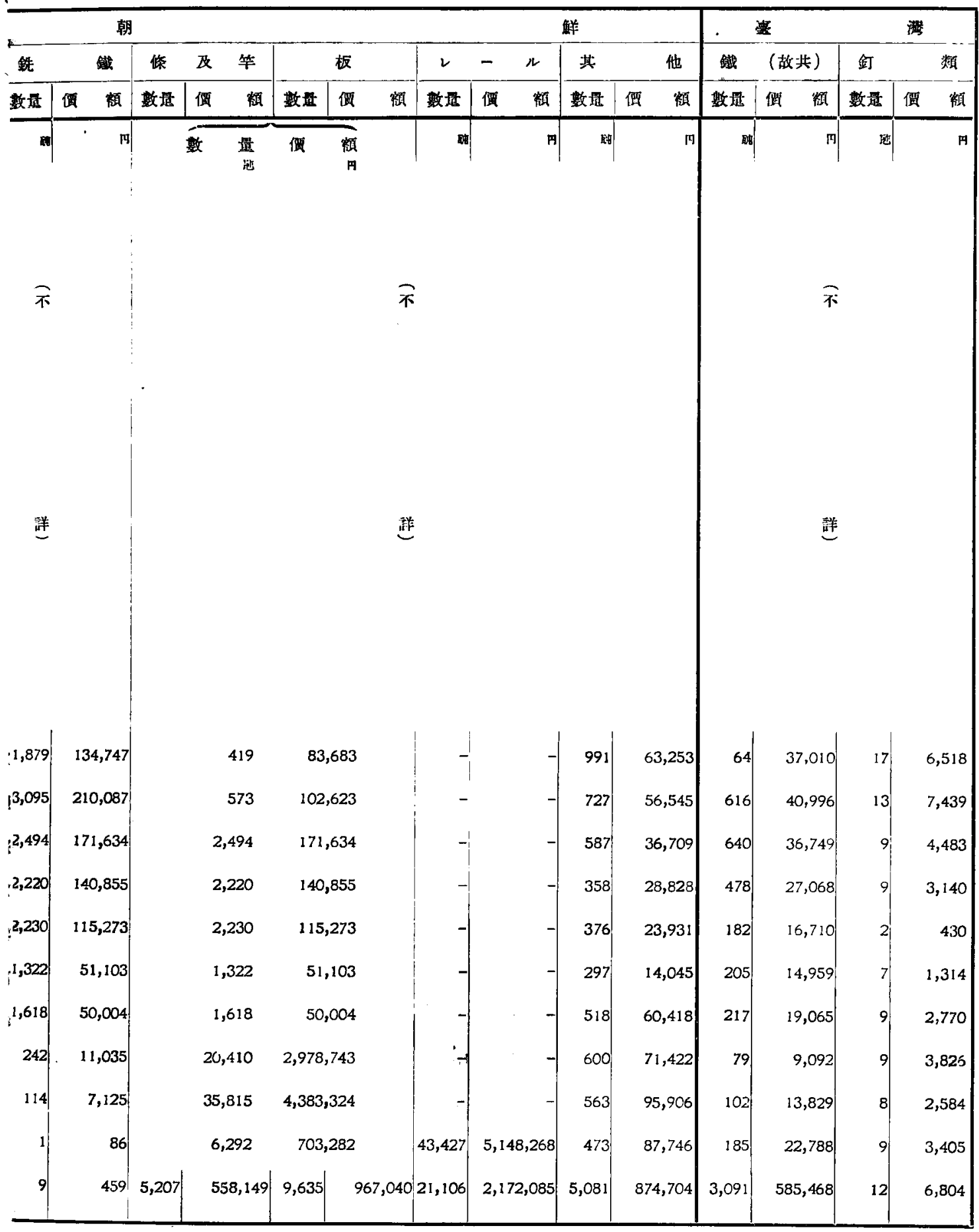


内地 鐵 鍓 林

（其

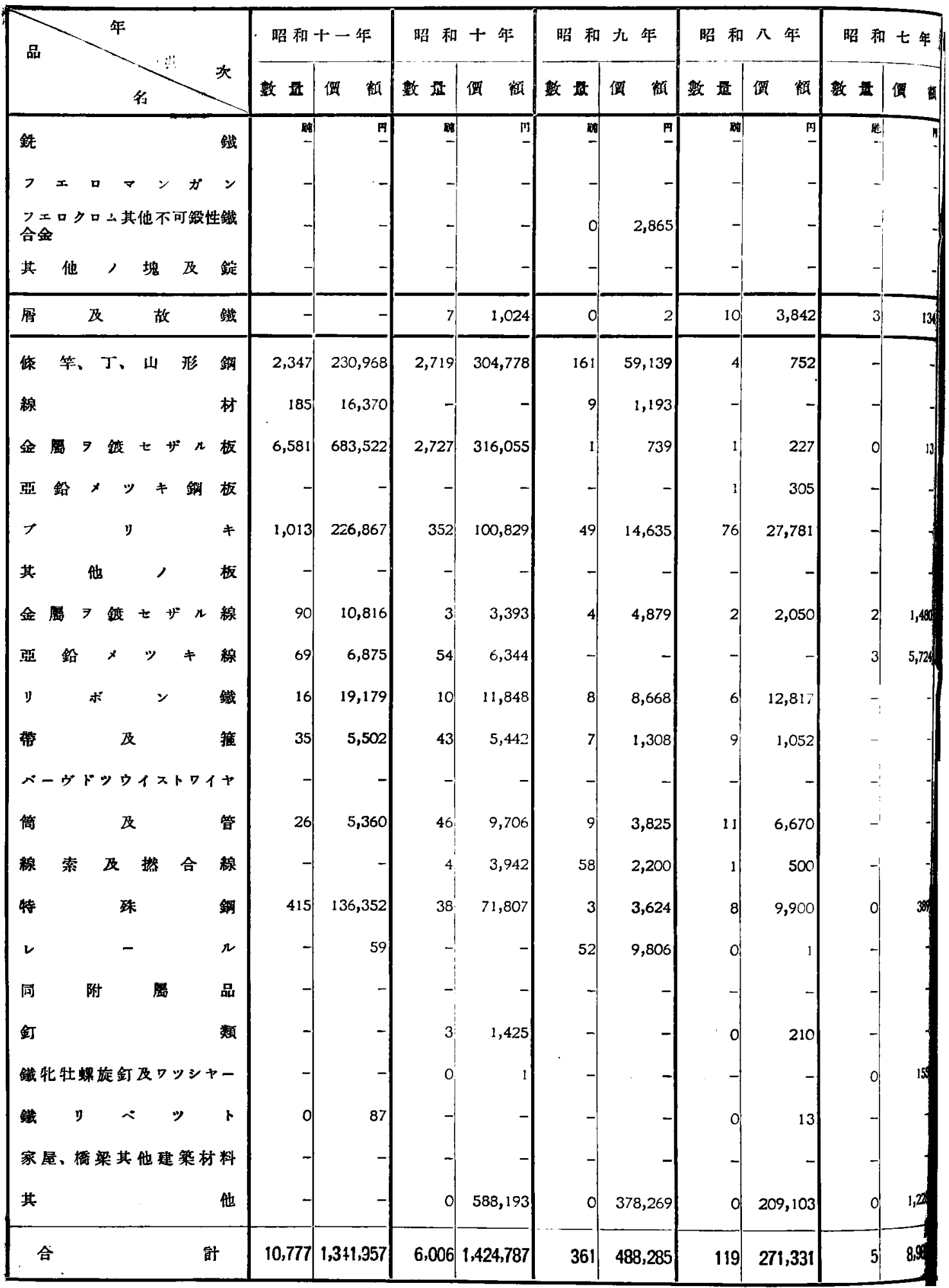




\section{再 輸 出 表}

$$
\text { -) }
$$

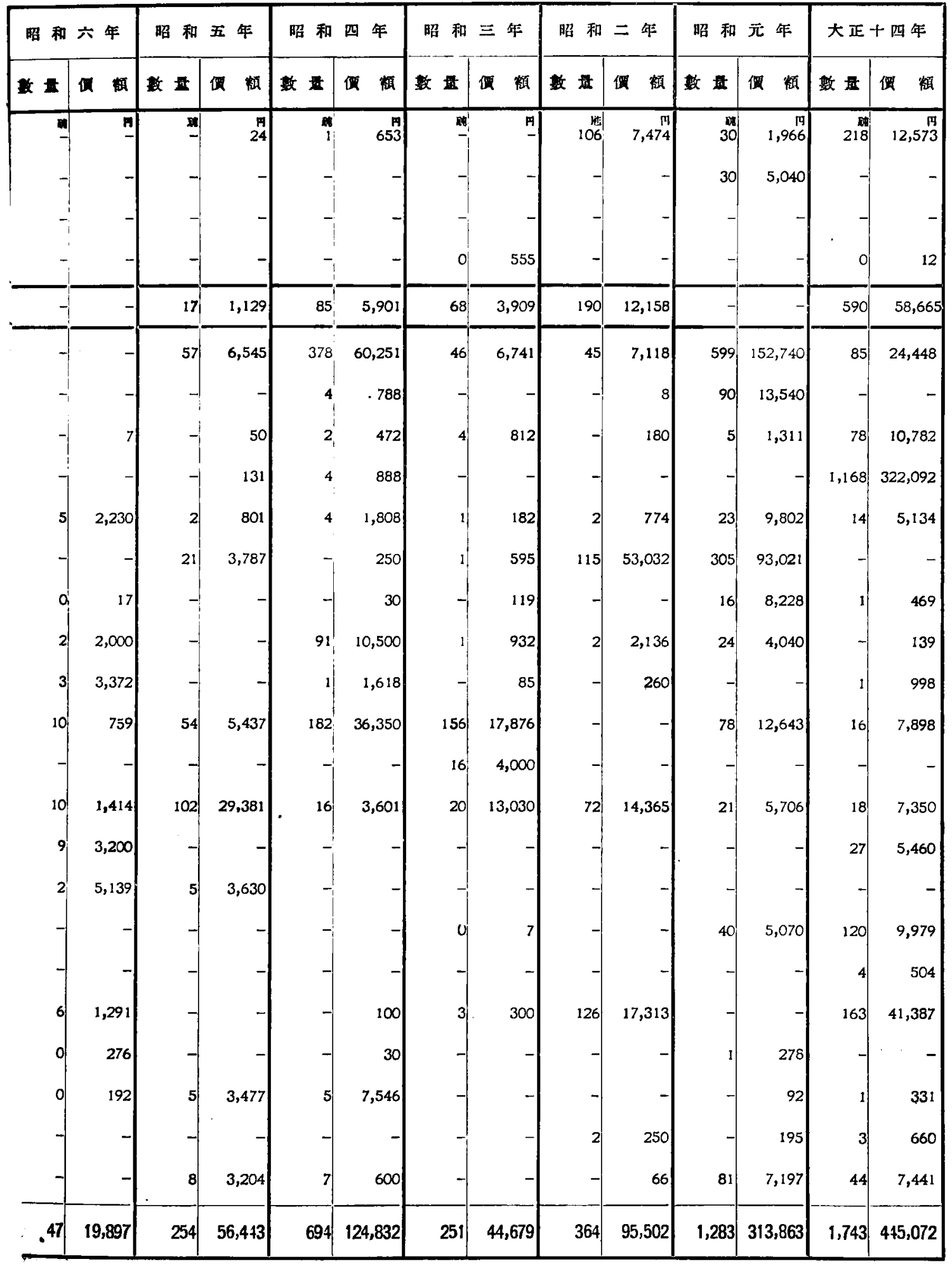


内地 鐵 鋼 材

(其

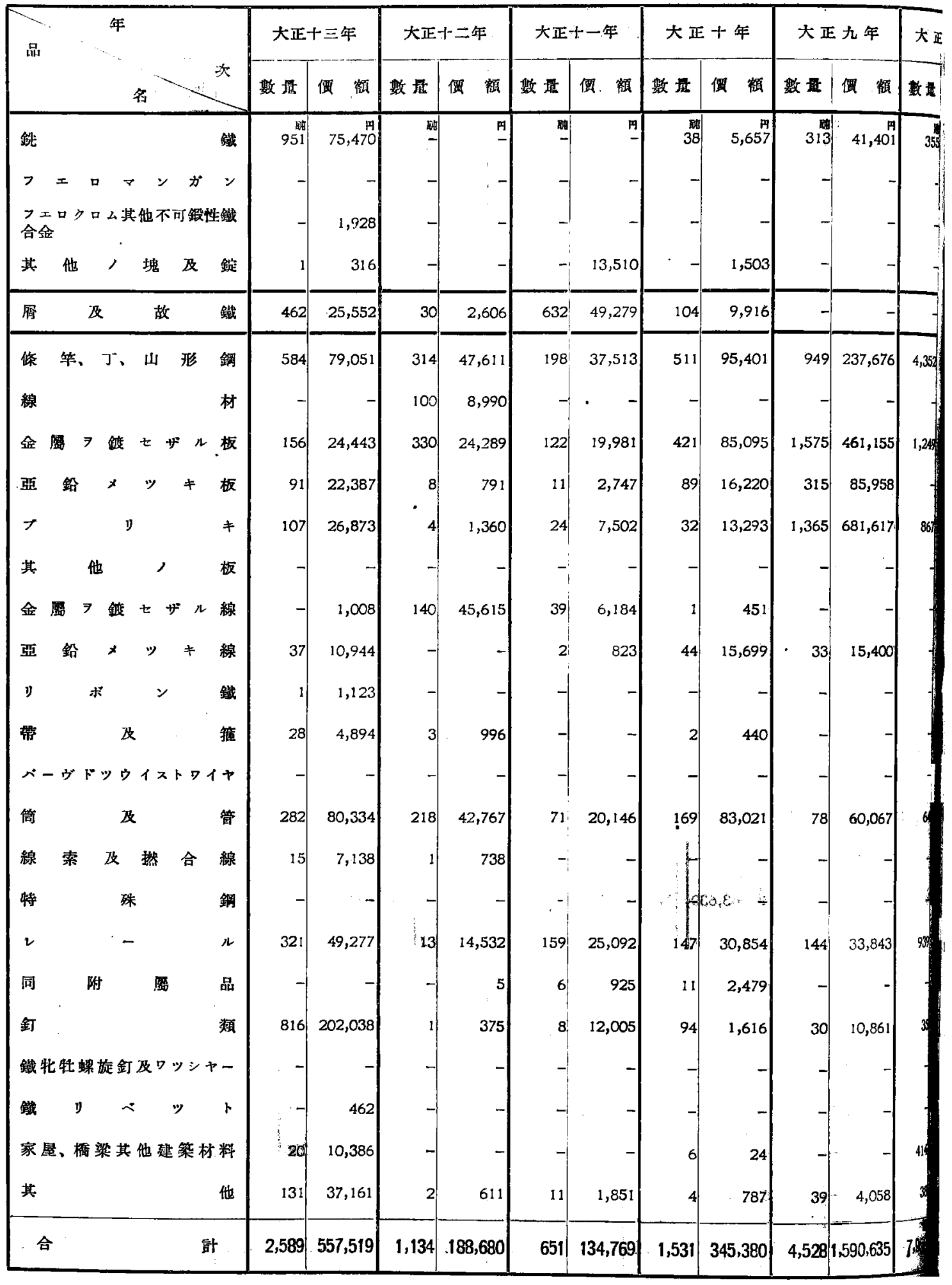


再 輸 出 表

二)

\begin{tabular}{|c|c|c|c|c|c|c|c|c|c|c|c|c|c|c|}
\hline \multirow{2}{*}{ 八 年 } & \multicolumn{2}{|c|}{ 大正七年 } & \multicolumn{2}{|c|}{ 大正六年 } & \multicolumn{2}{|c|}{ 大正五年 } & \multicolumn{2}{|c|}{ 大正四年 } & \multicolumn{2}{|c|}{ 大正三年 } & \multicolumn{2}{|c|}{ 大正二年 } & \multicolumn{2}{|c|}{ 大正元 年 } \\
\hline & 数量 & 僄 額 & 数㙁 & 佂 䅡 & 数数 & 価 額 & 数贯 & 覞 額 & 数郶 & 惯 顧 & 数量 & 價 頖 & 数量 & 㑑 顧 \\
\hline 57,875 & 120 & $\begin{array}{r}\text { म } \\
60,702\end{array}$ & 231 & $\begin{array}{r}\mathrm{A} \\
23,822\end{array}$ & 盟 & $\begin{array}{r}\text { म } \\
351\end{array}$ & 40 & 15,856 & $\begin{array}{r}10 \\
186\end{array}$ & $\begin{array}{r}\text { M } \\
9,107\end{array}$ & 358 & $\begin{array}{r}14 \\
17,789\end{array}$ & $\begin{array}{r}\text { 的 } \\
324\end{array}$ & $\begin{array}{r}17 \\
16,595\end{array}$ \\
\hline- & & 402 & 152 & 30,100 & - & - & & $\begin{array}{lll}- & - \\
-1\end{array}$ & 1 & 195 & 1,030 & 130,799 & - & - \\
\hline- & 45 & 9,075 & 21 & 1,610 & 18 & 1,274 & 6,529 & 257,684 & 9,608 & 323,011 & 9,378 & 343,829 & 6,021 & 197,556 \\
\hline$, 302,159$ & 9,011 & $4,532,480$ & 2,347 & 977,726 & 2,044 & 547,321 & 764 & 115,025 & 433 & 50,847 & 821 & 105,013 & 623 & 73,380 \\
\hline 458,039 & 1,576 & 904,716 & 1,460 & 704,910 & 2,316 & 651,772 & 927 & 135,427 & 304 & 32,799 & 190 & 20,578 & 485 & 60,917 \\
\hline 425,868 & 68 & 61,392 & 62 & 27,294 & 60 & 21,911 & 68 & 16,163 & 35 & 6,380 & 83 & 14,499 & 70 & 12,651 \\
\hline & 160 & 172,989 & 43 & 37,605 & 61 & 22,783 & .120 & 21,725 & 6 & 1,665 & - & - & - & - \\
\hline - & 4 & 2,373 & - & - & 18 & 9,067 & 127 & 10,047 & - & -1 & - & - & - & - \\
\hline- & 202 & 105,013 & 102 & 45,428 & 65 & 21,367 & 14 & 2,160 & 20 & 2,885 & - & - & 31 & 5,044 \\
\hline- & 2 & 987 & 78 & 29,813 & 163 & 47,235 & 31 & 3,924 & 17 & 2,482 & - & - & 78 & 8,322 \\
\hline 28,825 & 306 & 178,564 & 128 & 77,191 & 258 & 102,759 & 1,599 & 235,456 & 452 & 63,691 & 697 & 83,888 & 1,251 & 114,348 \\
\hline 271,118 & 3 & 5,575 & 69 & 22,565 & 161 & 29,093 & 221 & 15,638 & - & - & - & - & - & - \\
\hline 12,998 & 26 & 14,910 & 18 & 10,382 & 209 & 94,354 & 68 & 11,828 & - & - & 21 & 3,500 & & - \\
\hline 36,938 & & - & 66 & 20,848 & 32 & 9,313 & 41 & 7,487 & 65 & 6,948 & 73 & 7,474 & - & - \\
\hline 430 & 59 & 16,953 & 25 & 4,055 & 15 & 9,277 & 8 & 1,116 & 41 & $3 ; 776$ & 31 & 4,698 & 14 & 3,002 \\
\hline 375 & 11,4175 & $, 995,952$ & 4,398 & $1,957,817$ & 5,402 & $1,566,252$ & 3,988 & 575,996 & 1,373 & 171,473 & 9,916 & 239,650 & 2,552 & 277,664 \\
\hline
\end{tabular}


（其

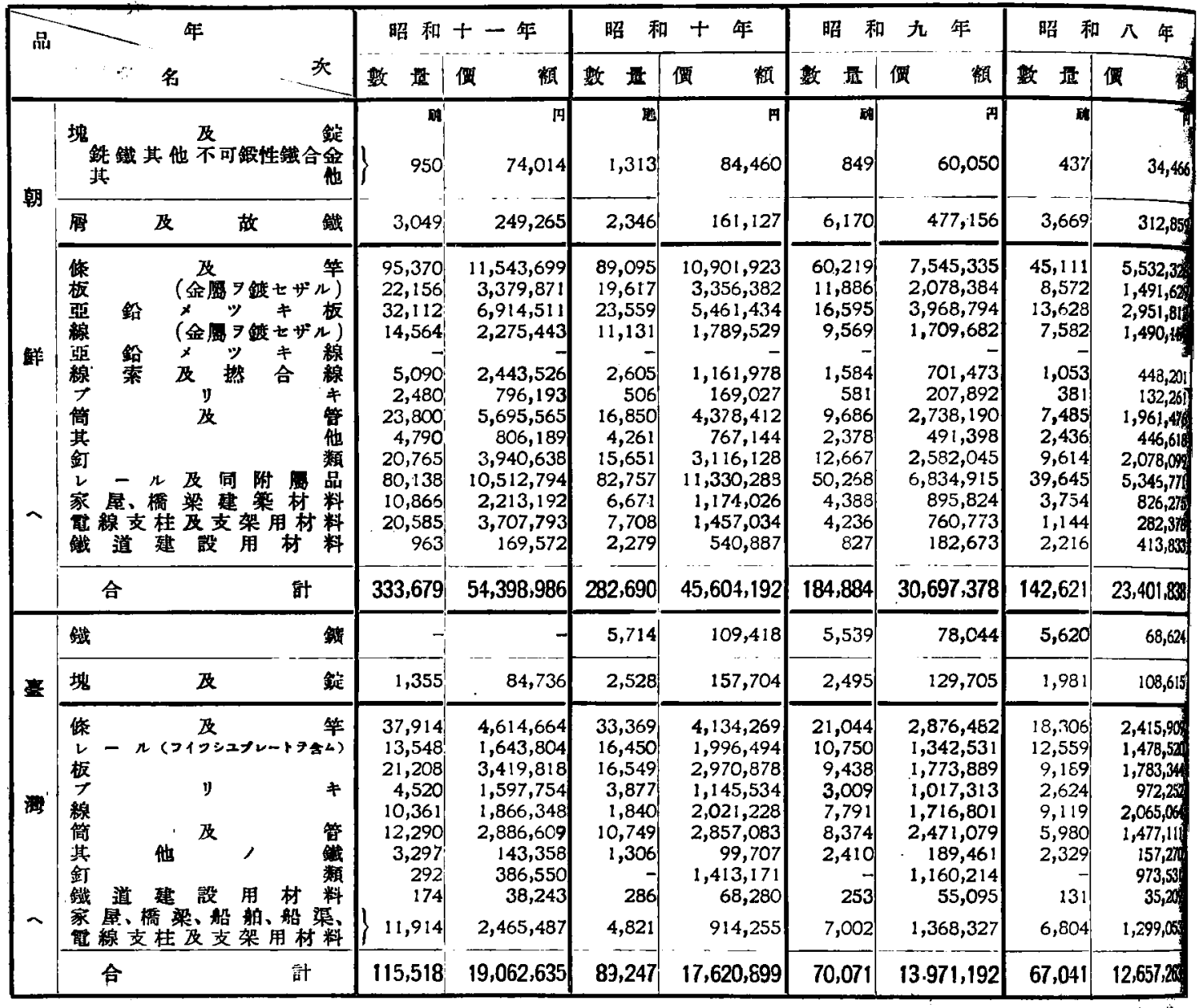

移

（其

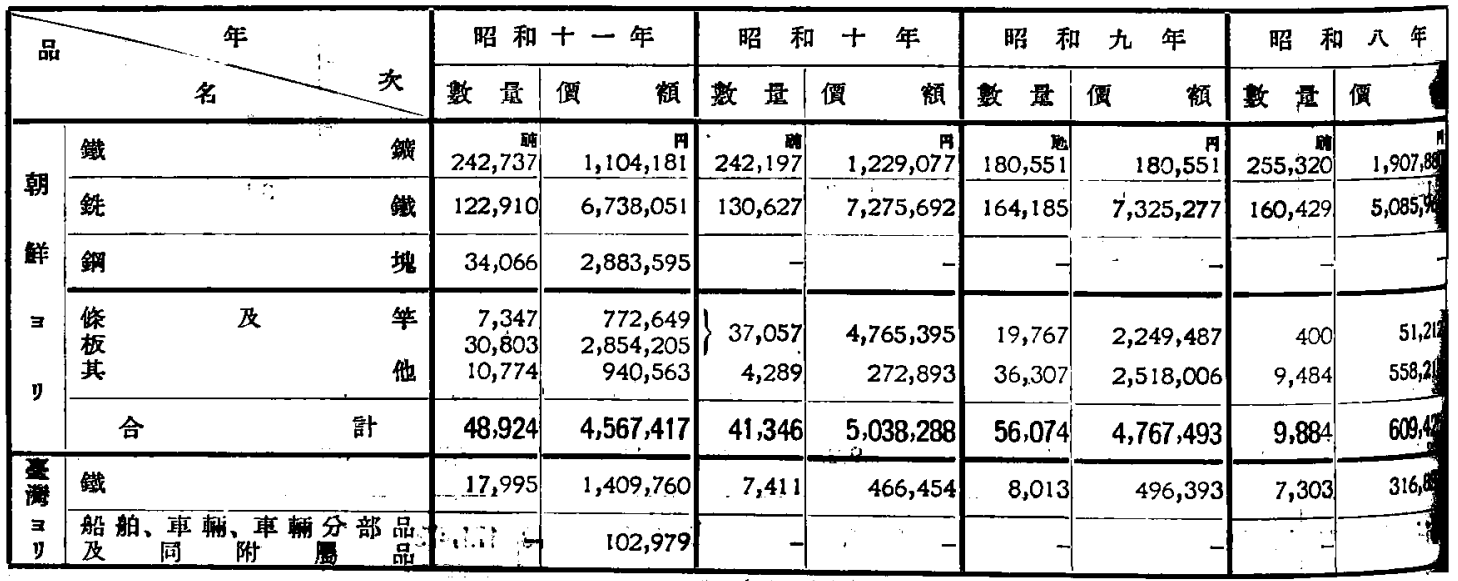




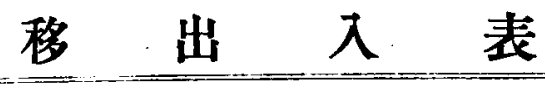

出

-)

\begin{tabular}{|c|c|c|c|c|c|c|c|c|c|}
\hline 和 & 年 & 昭 & 年 & 昭 和 & $\pi$ & 昭 & 四 & 昭 和 & $\equiv$ \\
\hline 最 & 顧 & 要 & 䄱頍 & 量 & 傊 & 塭 & 俓 & 数 堤 & 㒔 \\
\hline 652 & 44,110 & 820 & 53,990 & $\begin{array}{r}\text { 砘 } \\
1,459 \\
80\end{array}$ & $\begin{array}{r}\mathrm{H} \\
114,379 \\
9,616\end{array}$ & $\begin{array}{r}1,222 \\
80\end{array}$ & $\begin{array}{r}106,011 \\
8,518\end{array}$ & $\begin{array}{r}1,587 \\
4\end{array}$ & $\begin{array}{r}\text { म } \\
148,789 \\
567\end{array}$ \\
\hline 1,070 & 82,862 & 862 & 61,980 & 723 & 64,352 & 1,226 & 109,266 & 1,196 & 105,442 \\
\hline $\begin{array}{r}34,827 \\
7,762 \\
11,588\end{array}$ & $\begin{array}{l}3,719,640 \\
1,070,240 \\
2,414,820\end{array}$ & $\begin{array}{r}26,201 \\
9,042 \\
11,702\end{array}$ & $\begin{array}{l}2,707,426 \\
1,046,261 \\
2,434,723\end{array}$ & $\begin{array}{l}30,181 \\
13,167 \\
12,220\end{array}$ & $\begin{array}{l}4,092,299 \\
1,683,701 \\
3,116,640\end{array}$ & $\begin{array}{l}35,999 \\
10,330 \\
11,888\end{array}$ & $\begin{array}{l}5,019,545 \\
1,464,731 \\
3,323,895\end{array}$ & $\begin{array}{r}29,783 \\
8,620 \\
11,309\end{array}$ & $\begin{array}{l}4,165,201 \\
1,448,568 \\
3,216,521\end{array}$ \\
\hline 6,280 & 991,264 & 6,540 & 932,773 & $\begin{array}{r}985 \\
: \quad 4,263\end{array}$ & $\begin{array}{l}189,157 \\
705,671\end{array}$ & $\begin{array}{l}1,192 \\
4,400\end{array}$ & $\begin{array}{l}204,759 \\
768,256\end{array}$ & $\begin{array}{l}1,199 \\
3,942\end{array}$ & $\begin{array}{l}222,994 \\
732,430\end{array}$ \\
\hline 533 & 206,213 & 528 & 207,852 & 595 & 288,931 & $\cdot 655$ & 340,350 & & 415,551 \\
\hline & 93,458 & 371 & 92,505 & 490 & 136,722 & 720 & 214,734 & 452 & 146,350 \\
\hline 9,048 & $1,725,451$ & 6,485 & $1,158,320$ & 8,300 & $1,752,797$ & 7,683 & $1,717,457$ & 13,306 & $2,482,762$ \\
\hline $\begin{array}{l}1,110 \\
8,024\end{array}$ & $\begin{array}{r}198,714 \\
\end{array}$ & $\begin{array}{r}981 \\
7258\end{array}$ & 150,213 & 1,090 & 17,981 & 1,304 & 211,180 & 6851 & $\begin{array}{r}133,703 \\
1,507,392\end{array}$ \\
\hline 35,829 & $4,253,402$ & 21,142 & $2,703,474$ & 25,080 & $3,015,344$ & 31,558 & $4,029,201$ & 18,050 & $2,461,657$ \\
\hline 7,237 & $1,028,298$ & 2,054 & 394,664 & 4,679 & 945,964 & 3,099 & 719,937 & 4,482 & $1,015,836$ \\
\hline & $\begin{array}{r}1 / 0,079 \\
-\end{array}$ & 1,132 & 210,0 & 1,040 & 360 & .070 & & & 93,890 \\
\hline 123,640 & $17,259,228$ & 93,442 & $-13,326,387$ & 110,303 & $17,995,270$ & 117,769 & $20,024,782$ & 100,066 & $18,043,055$ \\
\hline 4,252 & 70,103 & 5,176 & $.91,395$ & 2,466 & 53,666 & 4,299 & 76,472 & - & - \\
\hline 1,444 & 63,611 & 1,338 & 70,181 & 3,784 & $239,27 !$ & 2,305 & 158,277 & 2,831 & 187,140 \\
\hline 20,316 & $1,862,998$ & 16,502 & $1,394,295$ & 18,722 & $1,928,955$ & 19,877 & $2,404,440$ & 18,331 & $2,227,787$ \\
\hline $\begin{array}{l}10,962 \\
2,072 \\
8,620 \\
6,775 \\
1,106 \\
2,007 \\
7,977\end{array}$ & $\begin{array}{r}1,687,742 \\
507,905 \\
1,554,013 \\
1,437,279 \\
82.277 \\
688,455 \\
783,388\end{array}$ & $\begin{array}{r}10,089 \\
2,121 \\
7,986 \\
8,901 \\
765 \\
1,881 \\
8,818\end{array}$ & $\begin{array}{r}1,575,029 \\
530,920 \\
1,180,034 \\
1,597,948 \\
63,709 \\
615,037 \\
954,992\end{array}$ & $\begin{array}{r}10,393 \\
1,274 \\
6,994 \\
3,968 \\
1,299 \\
1,693 \\
12,254\end{array}$ & $\begin{array}{r}1,764,749 \\
362,470 \\
1,091,598 \\
878,606 \\
317,623 \\
781,610 \\
1,398,565\end{array}$ & $\begin{array}{r}11,268 \\
1,693 \\
5,867 \\
5,736 \\
1,297 \\
1,721 \\
10,571\end{array}$ & $\begin{array}{r}2,264,415 \\
513,167 \\
1,001,688 \\
1,228,452 \\
375,073 \\
270,334 \\
1,252,329\end{array}$ & $\begin{array}{r}10,020 \\
1,764 \\
4,727 \\
6,450 \\
1,366 \\
1,605 \\
8,310\end{array}$ & $\begin{array}{r}2,048,848 \\
524,640 \\
847,466 \\
1,564,388 \\
377,128 \\
261,948 \\
1,010,699\end{array}$ \\
\hline 9,812 & $1,332,069$ & 3,922 & 586,406 & 2,761 & 632,574 & 1,777 & 422,240 & 6,171 & $1,698,622$ \\
\hline 69,647 & $9,936,126$ & 60,985 & $8,498,370$ & 59,358 & $9,156,750$ & 59,807 & $9,732,138$ & 58,744 & $10,561,526$ \\
\hline
\end{tabular}

入

-)

\begin{tabular}{|c|c|c|c|c|c|c|c|c|c|}
\hline 昭 & $t$ & 和 & 六 & 昭 & 五 & 昭 & 四 & 昭 & $\equiv$ \\
\hline 量 & 傮 & 數 & 唒 & 數 & 僧 & 数 & 售 & 數 & 偠 \\
\hline 151,60 & $\begin{array}{r}\text { m } \\
1,081,926\end{array}$ & 176,585 & $\begin{array}{r}1 \\
1,197,519 \\
\end{array}$ & $\begin{array}{r}\text { 垡 } \\
287,729 \\
\end{array}$ & $\begin{array}{r}\mathrm{m} \\
1,474,385 \\
\end{array}$ & 314,134 & $\begin{array}{r}\text { Py } \\
1,676,491 \\
\end{array}$ & $\begin{array}{r}\text { n } \\
225,389 \\
\end{array}$ & $\begin{array}{r}\text { 14 } \\
1,545,398 \\
\end{array}$ \\
\hline 205,955 & $6,178,657$ & 95,127 & $3,027,030$ & 109,432 & $5,404,119$ & 137,598 & $6,946,921$ & 139,832 & $6,998,400$ \\
\hline & - & & - & - & - & - & - & - & - \\
\hline 489 & 44,333 & 311 & 33,877 & 134 & 20,971 & 532 & 97,723 & 2,280 & $241 ; 463$ \\
\hline 5,042 & 211,105 & 2,076 & 101,308 & 2,126 & 119,525 & 4,561 & 285,018 & 1,903 & 166,441 \\
\hline 5,531 & 255,438 & 2,387 & 135,185 & 2,260 & 140,496 & 5,093 & 382,741 & 4,183 & 407,904 \\
\hline 4,138 & 150,049 & 1,437 & 42,576 & 1,702 & 56,621 & 3,414 & 147,149 & 2,070 & 101,277 \\
\hline & - & - & - & - & - & - & - & 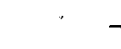 & $: r$ \\
\hline
\end{tabular}


（其

\begin{tabular}{|c|c|c|c|c|c|c|c|c|c|}
\hline \multirow[t]{2}{*}{ 品 } & \multirow{2}{*}{ 名 } & \multicolumn{2}{|c|}{ 昭 和 二 年 } & \multicolumn{2}{|c|}{ 昭 和 元 年 } & \multicolumn{2}{|c|}{ 大正十四年 } & \multicolumn{2}{|c|}{ 大正十三年 } \\
\hline & & 数 贵 & 顧 & 数 㙋 & 疑 & 数 趾 & 額 & 數 是 & 雖 \\
\hline & 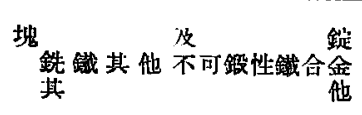 & $\begin{array}{r}1,964 \\
2\end{array}$ & $\begin{array}{r}194,511 \\
1,047\end{array}$ & 2,412 & $\begin{array}{r}234,579 \\
125\end{array}$ & $\begin{array}{r}1,644 \\
91\end{array}$ & $\begin{array}{r}171,847 \\
14,474\end{array}$ & $\begin{array}{r}1,691 \\
38\end{array}$ & $\begin{array}{r}157,363 \\
5,169\end{array}$ \\
\hline & 及 & 1,153 & 108,268 & 1,269 & 124,250 & 1,440 & 149,306 & 1,999 & 198,64 \\
\hline & 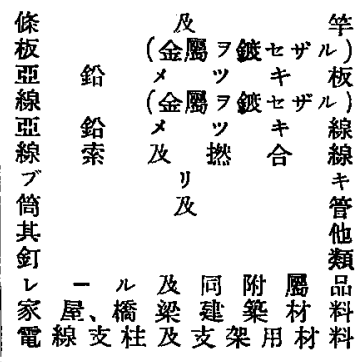 & $\begin{array}{r}26,396 \\
5,298 \\
9,910 \\
1,113 \\
3,138 \\
562 \\
355 \\
4,258 \\
924 \\
5,706 \\
23,31 \\
5,89 \\
335\end{array}$ & $\begin{array}{r}3,443,872 \\
879,896 \\
2,957,848 \\
213,210 \\
615,155 \\
291,214 \\
115,547 \\
1,008,957 \\
109,859 \\
1,219,308 \\
3,215,736 \\
1,315,935 \\
71,153\end{array}$ & $\begin{array}{r}16,074 \\
4,510 \\
8,168 \\
1,002 \\
2,091 \\
495 \\
350 \\
2,223 \\
741 \\
4,830 \\
12,656 \\
1,027 \\
70\end{array}$ & $\begin{array}{r}2,302,278 \\
776,082 \\
2,530,430 \\
217,988 \\
436,236 \\
237,725 \\
122,386 \\
573,732 \\
105,452 \\
1,186,778 \\
1,820,364 \\
221,778 \\
33,972\end{array}$ & $\begin{array}{r}10,019 \\
2,238 \\
6,440 \\
851 \\
1,115 \\
281 \\
360 \\
2,324 \\
748 \\
3,909 \\
5,382 \\
487 \\
12\end{array}$ & $\begin{array}{r}1,556,498 \\
428,092 \\
2,130,000 \\
232,531 \\
295,062 \\
133,971 \\
150,230 \\
593,092 \\
122,954 \\
989,988 \\
847,430 \\
143,788 \\
5,795\end{array}$ & $\begin{array}{r}10,660 \\
2,406 \\
6,487 \\
604 \\
1,12 \\
237 \\
55: \\
2,691 \\
5, \\
3,95 \\
3,700 \\
2,428 \\
9\end{array}$ & $\begin{array}{r}, 741,070 \\
483,486 \\
, 001,716 \\
164,941 \\
324,166 \\
155,726 \\
204,598 \\
646,921 \\
108,444 \\
, 098,846 \\
648,313 \\
605,020 \\
5,000\end{array}$ \\
\hline & 合 & 87,428 & $15,457,690$ & 54,237 & $10,565,201$ & 34,166 & 29,431 & 35,403 & 188,25 \\
\hline \multirow{5}{*}{ 吐 } & 鐵 & & & & & & & & \\
\hline & 塊 & 1,926 & 131,056 & 1,942 & 132,879 & 2,574 & 205,120 & 2,929 & 222,84 \\
\hline & 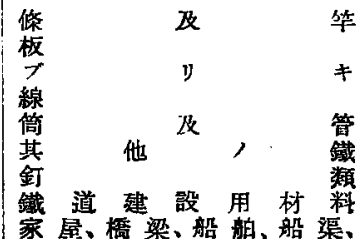 & $\begin{array}{r}17,510 \\
8,222 \\
1,702 \\
3,734 \\
5,904 \\
1,34 \\
1,46 \\
9,427\end{array}$ & $\begin{array}{r}2,093,930 \\
1,767,947 \\
536,102 \\
654,307 \\
1,494,902 \\
435,669 \\
223,544 \\
1,063,053\end{array}$ & $\begin{array}{r}15,920 \\
6,934 \\
1,622 \\
3,17 \\
3,350 \\
1,200 \\
1,273 \\
5,687\end{array}$ & & $\begin{array}{r}11,428 \\
5,254 \\
2,406 \\
2,56 \\
3,853 \\
1,153 \\
2,231 \\
6,563\end{array}$ & & $\begin{array}{r}7,305 \\
3,901 \\
3,437 \\
1,243 \\
2,023 \\
881 \\
1,912 \\
5,291\end{array}$ & $\begin{array}{l}, 088,041 \\
977,066 \\
, 332,360 \\
323,388 \\
635,388 \\
317,269 \\
531,779 \\
761,355\end{array}$ \\
\hline & 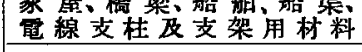 & & 611,3 & 446 & 80 & 624 & 175,5 & 1,891 & 479,506 \\
\hline & 合 & 52,023 & $8,880,819$ & 39,608 & 年 & 6,028 & $1,592,098$ & 24,884 & $6,446,65 \%$ \\
\hline
\end{tabular}

移

（其

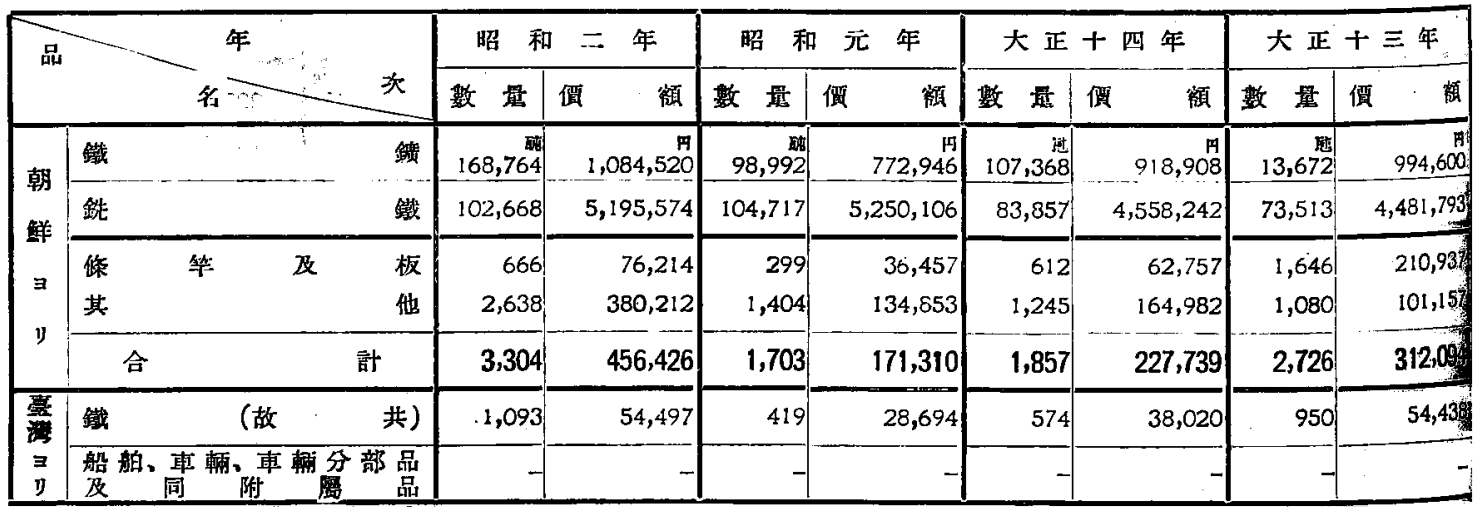


移出入表

出

二)

\begin{tabular}{|c|c|c|c|c|c|c|c|c|c|}
\hline \multicolumn{2}{|c|}{ 大 正十二年 } & \multicolumn{2}{|c|}{ 大正 十一年 } & \multicolumn{2}{|c|}{ 大 正 十 年 } & \multicolumn{2}{|c|}{ 大 正 九 年 } & \multicolumn{2}{|c|}{ 大 正 八 年 } \\
\hline 贵 & 䒜 & 是 & 顧 & 数 & 頖 & 数 & 類 & 数 & 貲 \\
\hline $\begin{array}{r}1,664 \\
21\end{array}$ & $\begin{array}{r}\text { f } \\
155,891 \\
7,053\end{array}$ & $\begin{array}{r}1,5 \\
1,526 \\
9\end{array}$ & $\begin{array}{r}\mathbf{m} \\
120,395 \\
1,506\end{array}$ & 2,066 & 293,221 & 969 & 196,916 & 1,139 & $\begin{array}{r}\mathrm{P} \\
178,394\end{array}$ \\
\hline 1,694 & 156,863 & 2,554 & 255,529 & 2,307 & 228,941 & 4,448 & 455,092 & 4,610 & 778,830 \\
\hline $\begin{array}{r}12,853 \\
2,411 \\
4,660 \\
554 \\
1,491 \\
257 \\
393 \\
4,253 \\
185 \\
3,249 \\
20,262 \\
4,098 \\
163\end{array}$ & $\begin{array}{r}1,997,985 \\
489,741 \\
1,461,909 \\
167,020 \\
451,521 \\
124,112 \\
160,959 \\
583,974 \\
51,036 \\
965,234 \\
2,628,887 \\
641,697 \\
42,742\end{array}$ & $\begin{array}{r}8,854 \\
1,770 \\
3,956 \\
220 \\
45 ! \\
230 \\
185 \\
2,486 \\
184 \\
1,857 \\
9,953 \\
2,457 \\
-\end{array}$ & $\begin{array}{r}1,286,515 \\
292,524 \\
854,833 \\
60,166 \\
121,104 \\
93,093 \\
50,718 \\
534,720 \\
28,265 \\
515,894 \\
955,057 \\
463,512 \\
-\end{array}$ & $\begin{array}{r}8,976 \\
1,983 \\
2,276 \\
151 \\
564 \\
137 \\
116 \\
1,184 \\
323 \\
1,392 \\
3,488 \\
2,961\end{array}$ & $\begin{array}{r}1,390,627 \\
333,325 \\
959,239 \\
37,912 \\
167,784 \\
62,663 \\
44,671 \\
344,216 \\
91,499 \\
623,080 \\
632,174 \\
787,206 \\
-\end{array}$ & $\begin{array}{r}3,742 \\
770 \\
1,136 \\
193 \\
795 \\
74 \\
9 \\
666 \\
87 \\
1,017 \\
4,823 \\
1,172 \\
-\end{array}$ & $\begin{array}{r}966,115 \\
193,599 \\
622,798 \\
52,947 \\
306,325 \\
45,714 \\
5,171 \\
289,094 \\
45,574 \\
494,050 \\
1,024,257 \\
302,002 \\
-\end{array}$ & $\begin{array}{r}6,341 \\
1,220 \\
657 \\
103 \\
736 \\
180 \\
2 \\
1,233 \\
395 \\
959 \\
14,237 \\
6 \\
-\end{array}$ & $\begin{array}{r}1,789,963 \\
427,618 \\
427,193 \\
34,772 \\
264,482 \\
164,476 \\
3,605 \\
551,846 \\
169,907 \\
637,194 \\
3,169,248 \\
1,200 \\
-\end{array}$ \\
\hline 54,829 & $10,036,814$ & 32,603 & $5,256,411$ & 23,551 & $5,479,396$ & 14,484 & $4,347,646$ & 26,069 & $7,641,504$ \\
\hline- & - & - & - & - & - & 8,075 & 103,350 & 2,656 & 33,927 \\
\hline 1,943 & 154,805 & 2,217 & 171,756 & 1,589 & 140,128 & 2,201 & 333,917 & 1,539 & 341,076 \\
\hline $\begin{array}{l}6,964 \\
2,917 ! \\
1,755 \\
2,048 \\
1,748 \\
1,055 \\
1,556 \\
5,650\end{array}$ & $\begin{array}{r}1,106,714 \\
734,307 \\
698,866 \\
551,307 \\
545,394 \\
273,159 \\
482,438 \\
834,099\end{array}$ & $\begin{array}{r}6,776 \\
3,258 \\
1,543 \\
3,274 \\
2,439 \\
821 \\
1,834 \\
12,039\end{array}$ & $\begin{array}{r}1,080,533 \\
864,253 \\
507,754 \\
804,543 \\
618,434 \\
214,652 \\
549,872 \\
1,819,131\end{array}$ & $\begin{array}{r}7,529 \\
3,909 \\
504 \\
4,342 \\
4,899 \\
1,766 \\
1,876 \\
6,280\end{array}$ & $\begin{array}{r}1,433,197 \\
1,121,027 \\
193,203 \\
1,188,747 \\
1,649,027 \\
305,718 \\
619,832 \\
1,254,330\end{array}$ & $\begin{array}{r}5,950 \\
3,615 \\
1,103 \\
2,518 \\
1,853 \\
1,099 \\
2,046 \\
16,768\end{array}$ & $\begin{array}{r}1,647,502 \\
1,250,387 \\
563,981 \\
981,254 \\
738,370 \\
333,156 \\
894,052 \\
4,362,740\end{array}$ & $\begin{array}{r}4,468 \\
1,633 \\
353 \\
1,193 \\
1,726 \\
700 \\
1,835 \\
6,182\end{array}$ & $\begin{array}{r}1,304,820 \\
693,224 \\
196,440 \\
873,604 \\
628,690 \\
202,431 \\
782,152 \\
1,782,813\end{array}$ \\
\hline 1,549 & 426,233 & 479 & 151,195 & 4,000 & $1,425,489$ & 1,387 & 428,470 & 1,083 & 323,747 \\
\hline 25,242 & $5,652,517$ & 32,463 & $6,610,367$ & 35,105 & $9,190,570$ & 36,339 & $11,259,912$ & 19,173 & $6,787,621$ \\
\hline
\end{tabular}

入

二)

\begin{tabular}{|c|c|c|c|c|c|c|c|c|c|}
\hline \multicolumn{2}{|c|}{ 大正 $+=$ 年 } & \multicolumn{2}{|c|}{ 大正十一年 } & 大 正 & t & \multicolumn{2}{|c|}{ 大 正 九 年 } & \multicolumn{2}{|c|}{ 大 正八 年 } \\
\hline 量 & 洒 & 数 & 頼 & 数 & 額 & 數 & 價 & 數 & 價 \\
\hline $\begin{array}{r}59,390 \\
0\end{array}$ & $725,71{ }^{\text {P1 }}$ & 89,827 & 767,982 & $\begin{array}{r}\text { 赌 } \\
190,541\end{array}$ & $\begin{array}{r}\text { 19 } \\
1,702,277\end{array}$ & 332,533 & $\begin{array}{r}\text { 叫 } \\
3,358,037 \\
\end{array}$ & $\begin{array}{r}\text { 酺 } \\
333,521 \\
\end{array}$ & $2,340,384_{4}^{\text {P }}$ \\
\hline 81,916 & $5,691,677$ & 80,001 & $6,283,023$ & 48,055 & $4,073,606$ & 40,743 & $5,821,270$ & 62,387 & $9,735,064$ \\
\hline $\begin{array}{r}1,656 \\
674\end{array}$ & $\begin{array}{r}310,950 \\
48,387\end{array}$ & $\begin{array}{r}11,851 \\
540\end{array}$ & $\begin{array}{r}2,497,694 \\
15,034\end{array}$ & $\begin{array}{r}21,053 \\
119\end{array}$ & $\begin{array}{r}4,450,323 \\
13,464\end{array}$ & $\begin{array}{r}14,628 \\
47\end{array}$ & $\begin{array}{r}5,136,380 \\
12,056\end{array}$ & $\begin{array}{r}3,053 \\
107\end{array}$ & $\begin{array}{r}867,948 \\
9,123\end{array}$ \\
\hline 2,330 & 359,337 & 12,391 & $2,512,728$ & 21,172 & $4,463,787$ & 14,675 & $5,148,436$ & 3,160 & 877,071 \\
\hline 428 & 38,348 & 224 & 19,922 & 52 & 4,890 & 130 & 14,224 & 1,129 & 180,638 \\
\hline & . & & & . & & & 22 & - & - \\
\hline
\end{tabular}


移

（其

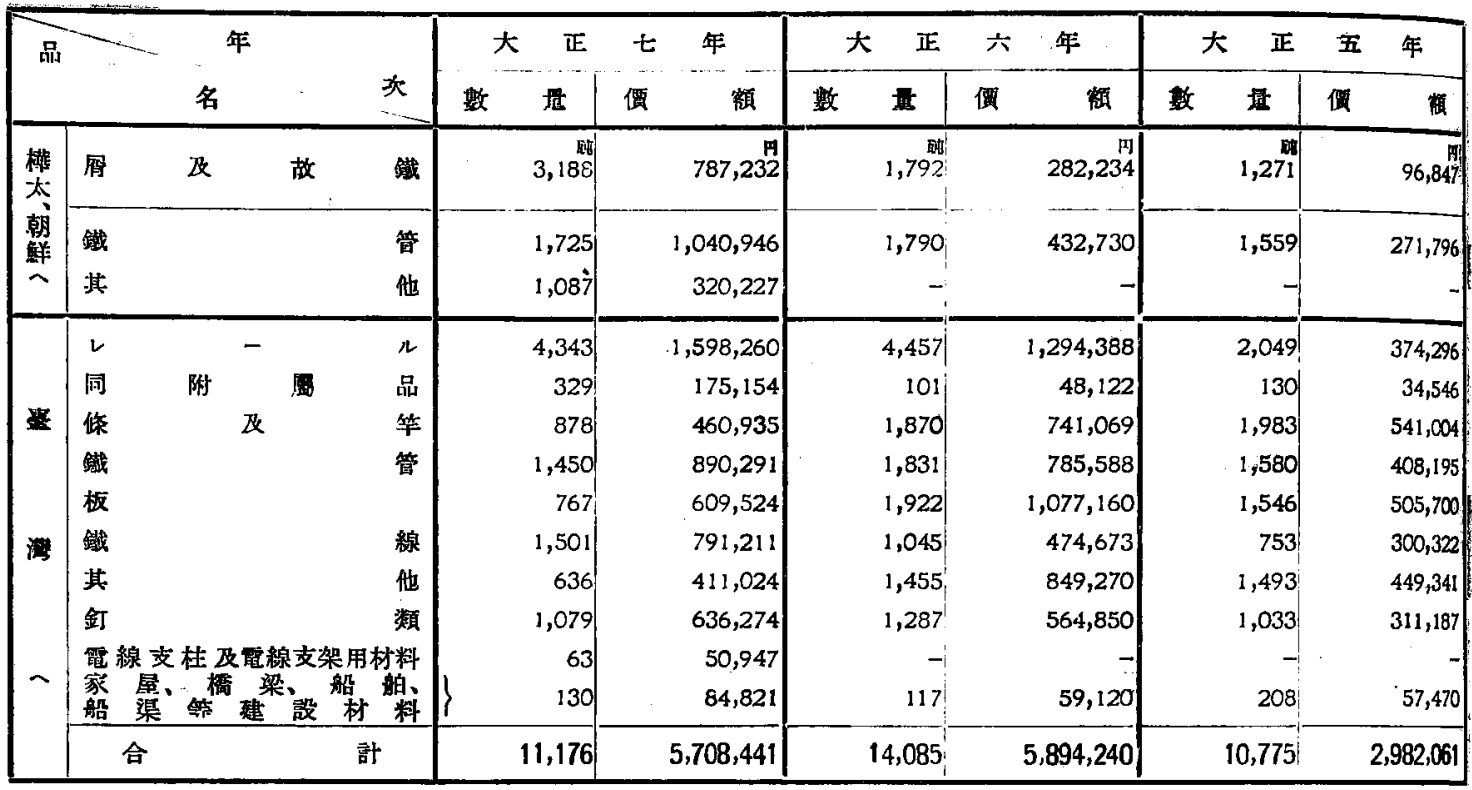

移

（其

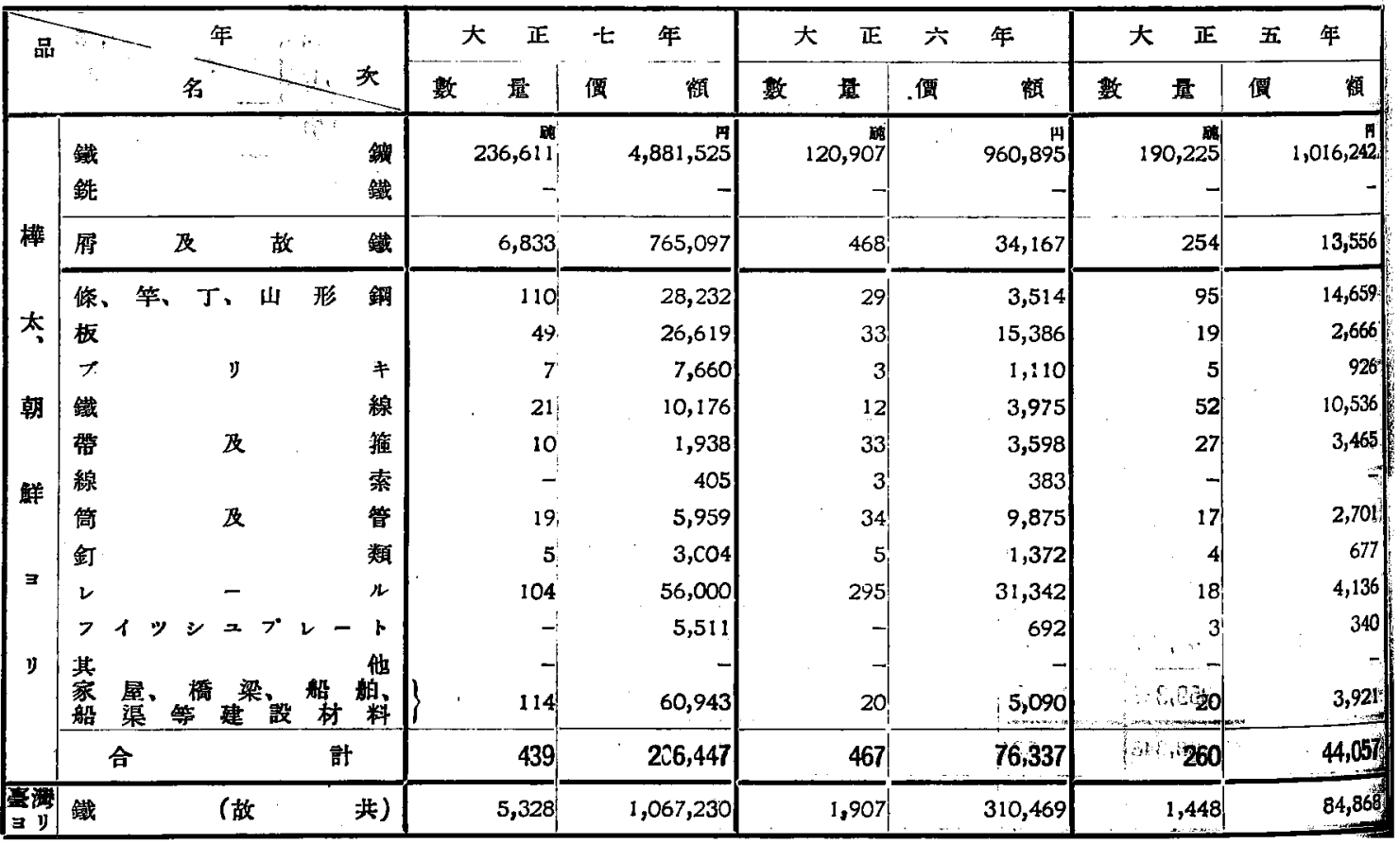




\section{移出入表}

出

\section{三)}

\begin{tabular}{|c|c|c|c|c|c|c|c|c|c|c|c|c|c|c|c|}
\hline 大 & 正 & $\mu$ & 年 & & 正 & $\equiv$ & 年 & た & 正 & & 年 & \multicolumn{2}{|c|}{ 大 } & 元 & 年 \\
\hline 数 & 量 & 偪 & 頝 & 数 & 连 & 㵋 & 蝢 & 数 & 量 & 摆 & 顁 & 数 & 基 & 㗄 & 唃 \\
\hline & $\begin{array}{r}\text { 15 } \\
797\end{array}$ & & 37,240 & & $\begin{array}{r}\text { 䧺 } \\
925\end{array}$ & & $\begin{array}{r}\mathrm{P} \\
35,544\end{array}$ & & $\begin{array}{r}\text { nd } \\
1,741\end{array}$ & & $\begin{array}{r}\mathrm{M} \\
69,675\end{array}$ & & 1,700 & & 64,017 \\
\hline & 1,545 & & 142,174 & & 1,752 & & 127,611 & & 2,460 & & 203,342 & & 4,214 & & 291,911 \\
\hline & 2,404 & & 211,473 & & 1,1111 & & 99,553 & & 1,116 & & 99,122 & & 1,922 & & 171,825 \\
\hline & 66 & & 9,854 & & 143 & & 15,988 & & 52 & & 7,521 & & 132 & & 20,501 \\
\hline & 2,498 & & 335,628 & & 3,542 & & 361,729 & & 3,150 & & 324,091 & & 3,905 & & 394,340 \\
\hline & 2,762 & & 351,878 & & 3,027 & & 407,593 & & 2,268 & & 299,994 & & 2,331 & & 302,126 \\
\hline & 1,770 & & 350,661 & & 1,847 & & 295,271 & & 2,098 & & 325,420 & & & & \\
\hline & 1,262 & & 278,349 & & 2,162 & & 306,767 & & 2,523 & & 370,756 & & 10,492 & & $1,183,359$ \\
\hline & 3,023 & & 325,960 & & 2,260 & & 173,115 & & 2,904 & & 272,906 & & & & \\
\hline & 1,022 & & 204,879 & & 1,194 & & 180,445 & & 1,005 & & 203,856 & & 1,628 & & 254,648 \\
\hline & 703 & & 113,662 & & 678 & & 92,701 & & 2,209 & & 343,277 & & 2,232 & & 327,034 \\
\hline$\ldots$ & 15,510 & & $2,182,344$ & & 15,964 & & $1,933,162$ & & 17,325 & & $2,246,943$ & & $22,6+2$ & & $2,653,833$ \\
\hline
\end{tabular}

入

三)

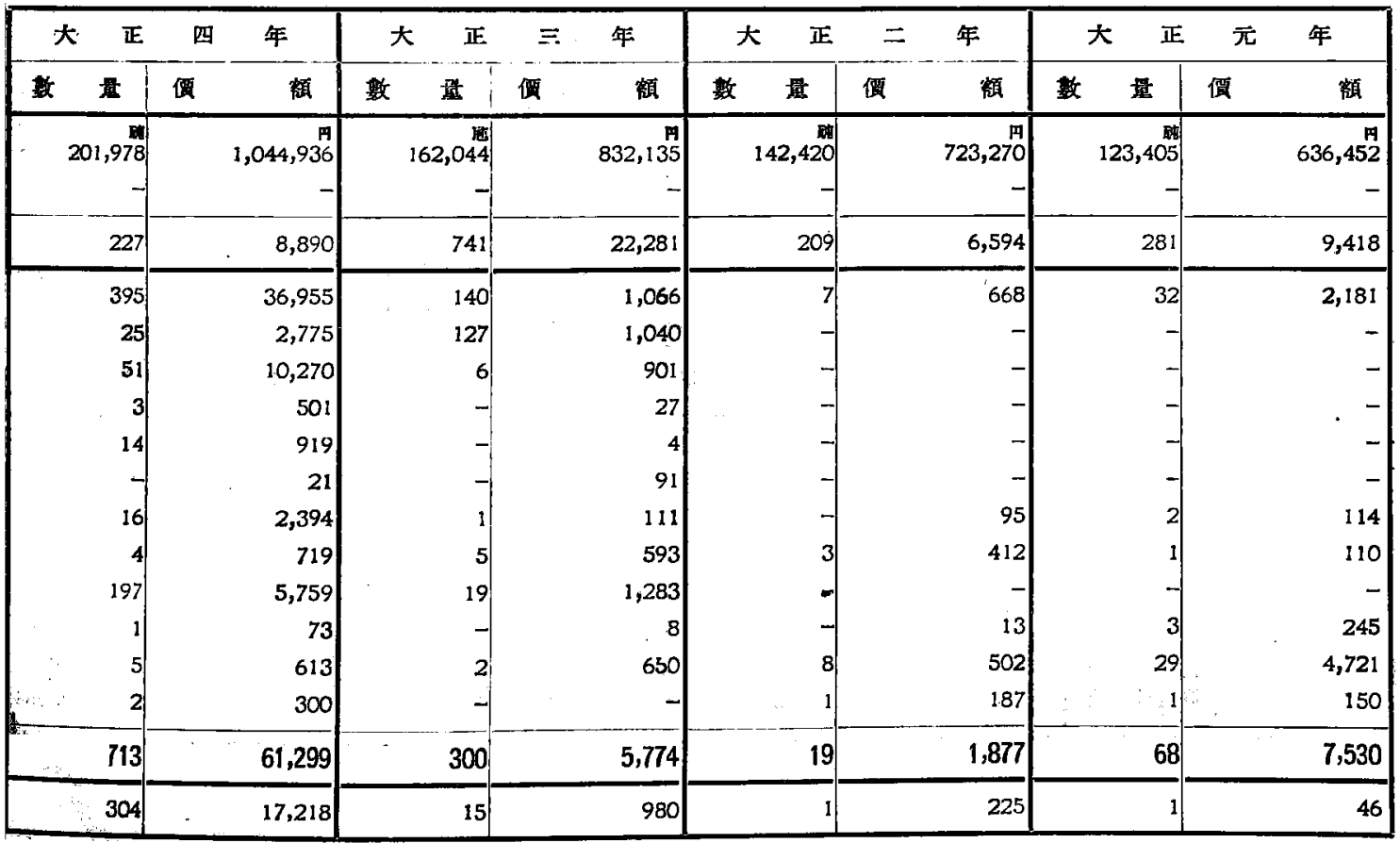


内地普通鋼壓延

(其

\begin{tabular}{|c|c|c|c|c|c|c|c|c|c|c|c|c|}
\hline \multirow{2}{*}{\multicolumn{3}{|c|}{ 品 }} & \multicolumn{5}{|c|}{ レ一、ル 及附露品 } & \multicolumn{3}{|c|}{ 㱫 } & \multicolumn{2}{|c|}{ 鈨 } \\
\hline & & & $\begin{array}{l}\text { 45诗度 } \\
\text { 以 上 }\end{array}$ & $\begin{array}{l}\text { 45封庫 } \\
\text { 未 濑 }\end{array}$ & $\begin{array}{l}\text { フィッ } \\
シ ニ フ ゚ ~ \\
レ ー ト\end{array}$ & 其 他 & 鱽 & 九 銓 & 角 銅 & 平 鍓 & 其 & 敬 \\
\hline 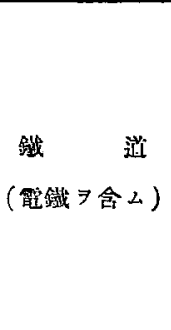 & 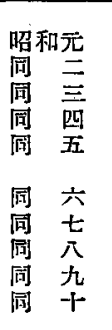 & $\begin{array}{l}\text { 年 } \\
\text { 年 } \\
\text { 年 } \\
\text { 年 } \\
\text { 年 } \\
\text { 年 } \\
\text { 年 } \\
\text { 年 } \\
\text { 年 } \\
\text { 年 }\end{array}$ & $\begin{array}{r}\text { nt } \\
138,822 \\
169,024 \\
231,108 \\
191,822 \\
144,526 \\
\\
86,547 \\
125,109 \\
86,029 \\
165,443 \\
117,445\end{array}$ & $\begin{array}{r}\text { and } \\
2,271 \\
3,402 \\
7,863 \\
2,744 \\
2,056 \\
\\
1,996 \\
1,626 \\
2,340 \\
76: \\
3,044\end{array}$ & $\begin{array}{r}8,245 \\
8,433 \\
8,409 \\
9,509 \\
11,970 \\
8,987 \\
\\
3,588 \\
5,485 \\
4,511 \\
13,408 \\
5,847\end{array}$ & $\begin{array}{r}\text { mg } \\
2,773 \\
947 \\
4,253 \\
5,350 \\
865 \\
\\
609 \\
2,415 \\
2,024 \\
585 \\
1,926\end{array}$ & $\begin{array}{r}\text { 响 } \\
152,111 \\
181,806 \\
252,733 \\
211,896 \\
156,434 \\
\\
92,740 \\
134,635 \\
94,904 \\
180,197 \\
128,262\end{array}$ & 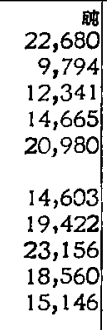 & $\begin{array}{r}\text { 蠤 } \\
5,895 \\
4,102 \\
7,578 \\
10,500 \\
5,720 \\
\\
4,417 \\
6,511 \\
16,195 \\
19,139 \\
7,225\end{array}$ & $\begin{array}{r}\text { 哺 } \\
7,903 \\
4,990 \\
5,407 \\
6,729 \\
4,707 \\
\\
8,747 \\
8,294 \\
9,185 \\
11,659 \\
8,381\end{array}$ & \begin{tabular}{r|} 
rof \\
1,337 \\
166 \\
6,998 \\
497 \\
565 \\
\\
1,273 \\
971 \\
405 \\
210 \\
754
\end{tabular} & $\begin{array}{l}37,8 \\
19,05 \\
32,32 \\
32,39 \\
31,97 \\
\\
29,04 \\
35,19 \\
48,99 \\
49,56 \\
31,50\end{array}$ \\
\hline $\begin{array}{l}\text { 士末建築 } \\
\text { 鐵骨榄造 }\end{array}$ & $\begin{array}{l}\text { 昭和元 } \\
\text { 同 } \\
\text { 同 } \\
\text { 同 } \\
\text { 同 } \\
\text { 五 } \\
\text { 同 } \\
\text { 同 } \\
\text { 同 } \\
\text { 同 } \\
\text { 同 九 } \\
\text { 同 十 }\end{array}$ & $\begin{array}{l}\text { 年 } \\
\text { 年 } \\
\text { 年 } \\
\text { 年 } \\
\text { 年 } \\
\text { 年 } \\
\text { 年 } \\
\text { 年 } \\
\text { 年 } \\
\text { 年 }\end{array}$ & $\begin{array}{r}383 \\
77 \\
3,181 \\
2,243 \\
1,801 \\
\\
765 \\
622 \\
1,040 \\
684 \\
779\end{array}$ & $\begin{array}{r}708 \\
2,034 \\
5,833 \\
4,077 \\
6,242 \\
\\
8,475 \\
12,479 \\
13,784 \\
13,255 \\
14,536\end{array}$ & $\begin{array}{r}68 \\
94 \\
387 \\
322 \\
353 \\
\\
661 \\
2,484 \\
669 \\
467 \\
1,287\end{array}$ & $\begin{array}{r}64 \\
82 \\
1,169 \\
298 \\
411 \\
\\
346 \\
750 \\
674 \\
807 \\
1,146\end{array}$ & $\begin{array}{r}1,223 \\
2,287 \\
10,570 \\
6,940 \\
8,807 \\
\\
10,247 \\
16,335 \\
16,167 \\
15,213 \\
17,748\end{array}$ & $\begin{array}{l}143,258 \\
127,892 \\
234,603 \\
293,754 \\
287,785 \\
\\
200,869 \\
291,837 \\
359,131 \\
382,275 \\
430,412\end{array}$ & $\begin{array}{r}6,231 \\
9,326 \\
9,872 \\
10,154 \\
10,266 \\
\\
8,202 \\
10,638 \\
11,969 \\
11,498 \\
12,271\end{array}$ & $\begin{array}{l}12,195 \\
20,562 \\
19,460 \\
31,325 \\
22,145 \\
\\
20,849 \\
30,067 \\
27,412 \\
25,174 \\
13,300\end{array}$ & $\begin{array}{r}3,770 \\
944 \\
1,478 \\
1,346 \\
2,061 \\
\\
5,280 \\
2,780 \\
1,524 \\
2,123 \\
1,805\end{array}$ & $\begin{array}{l}165,45 \\
158,72 \\
265,41 \\
336,57 \\
322,2 \\
2 \\
235,2 \\
335,32 \\
400,08 \\
421,0 \\
457,7\end{array}$ \\
\hline 船 & 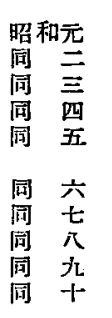 & $\begin{array}{l}\text { 年 } \\
\text { 年 } \\
\text { 年 } \\
\text { 年 } \\
\text { 年 } \\
\text { 年 } \\
\text { 年 } \\
\text { 年 } \\
\text { 年 } \\
\text { 年 }\end{array}$ & $\begin{array}{r}635 \\
12 \\
153 \\
530 \\
99 \\
57 \\
589 \\
1,034 \\
661 \\
1,251\end{array}$ & $\begin{array}{r}36 \\
8 ! \\
1,341 \\
73 \\
25 \\
503 \\
175 \\
753 \\
440 \\
149\end{array}$ & $\begin{array}{r}34 \\
2 \\
6 \\
32 \\
10 \\
11 \\
23 \\
34 \\
80 \\
124\end{array}$ & $\begin{array}{r}90 \\
2 \\
7 \\
30 \\
74 \\
51 \\
123 \\
256 \\
173 \\
230\end{array}$ & $\begin{array}{r}795 \\
97 \\
1,507 \\
665 \\
208 \\
\\
622 \\
910 \\
2,127 \\
1,354 \\
1,754\end{array}$ & $\begin{array}{r}6,710 \\
10,327 \\
16,088 \\
17,259 \\
11,685 \\
\\
14,076 \\
16,551 \\
31,020 \\
30,352 \\
28,677\end{array}$ & $\begin{array}{l}1,705 \\
i, 505 \\
3,017 \\
3,898 \\
2,257 \\
\\
2,982 \\
3,345 \\
3,391 \\
5,753 \\
4,042\end{array}$ & $\begin{array}{r}3,106 \\
9,574 \\
6,265 \\
7,186 \\
6,037 \\
\\
6,916 \\
7,312 \\
7,354 \\
12,064 \\
16,303\end{array}$ & $\begin{array}{r}410 \\
4,828 \\
2,180 \\
682 \\
411 \\
\\
1,381 \\
542 \\
1,923 \\
4,777 \\
2,223\end{array}$ & $\begin{array}{l}11,931 \\
26,234 \\
27,550 \\
29,025 \\
20,390 \\
25,355 \\
27,750 \\
43,60 \\
52,96 \\
51,24,\end{array}$ \\
\hline 機栈鐵工策 & $\begin{array}{l}\text { 昭和元 } \\
\text { 同 } \\
\text { 同 } \\
\text { 同 } \\
\text { 同 } \\
\text { 西 } \\
\text { 同 六 } \\
\text { 同 } \\
\text { 同 } \\
\text { 同 } \\
\text { 同 } \\
\text { 占 }\end{array}$ & $\begin{array}{l}\text { 年 } \\
\text { 年 } \\
\text { 年 } \\
\text { 年 } \\
\text { 年 } \\
\text { 年 } \\
\text { 年 } \\
\text { 年 } \\
\text { 年 } \\
\text { 年 }\end{array}$ & $\begin{array}{r}306 \\
191 \\
2,223 \\
553 \\
1,106 \\
\\
831 \\
119 \\
300 \\
747 \\
1,165\end{array}$ & $\begin{array}{r}21 \\
64 \\
128 \\
367 \\
177 \\
\\
712 \\
106 \\
177 \\
638 \\
274\end{array}$ & $\begin{array}{r}47 \\
29 \\
117 \\
24 \\
9 \\
10 \\
14 \\
40 \\
68 \\
237\end{array}$ & $\begin{array}{r}9 \\
79 \\
30 \\
15 \\
24 \\
5 \\
5 \\
40 \\
8 \\
208\end{array}$ & $\begin{array}{r}383 \\
363 \\
2,498 \\
959 \\
1,316 \\
\\
1,558 \\
245 \\
557 \\
1,461 \\
1,884\end{array}$ & $\begin{array}{r}42,690 \\
36,582 \\
47,333 \\
57,416 \\
38,201 \\
\\
43,527 \\
55,766 \\
124,403 \\
133,319 \\
109,478\end{array}$ & $\begin{array}{r}9,288 \\
12,394 \\
13,535 \\
16,935 \\
12,397 \\
14,342 \\
18,954 \\
30,858 \\
33,420 \\
30,008\end{array}$ & $\begin{array}{r}19,809 \\
27,758 \\
26,858 \\
30,044 \\
21,913 \\
27,547 \\
202,344 \\
253,207 \\
74,406 \\
81,247\end{array}$ & $\begin{array}{r}857 \\
927 \\
59,261 \\
8,424 \\
2,156 \\
\\
7,787 \\
72,182 \\
49,569 \\
12,658 \\
6,872\end{array}$ & $\begin{array}{r}72,64 \\
77,661 \\
146,98 \\
112,81 \\
74,667 \\
\\
93,2 \\
349,24 \\
458,09 \\
253,809 \\
227,64\end{array}$ \\
\hline $\begin{array}{l}\text { 石 } \\
\text { 压 } \\
\text { 水 }\end{array}$ & 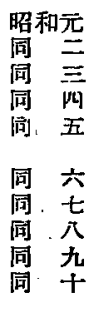 & $\begin{array}{l}\text { 年 } \\
\text { 年 } \\
\text { 年 } \\
\text { 年 } \\
\text { 年 } \\
\text { 年 } \\
\text { 年 } \\
\text { 年 } \\
\text { 年 } \\
\text { 年 }\end{array}$ & $\begin{array}{r}1 \\
10 \\
9 \\
1 \\
22 \\
2 \\
5 \\
10 \\
384\end{array}$ & \begin{tabular}{r|}
2 \\
.2 \\
51 \\
35 \\
41 \\
274 \\
98 \\
20 \\
11 \\
47
\end{tabular} & $\begin{array}{r}- \\
- \\
- \\
3 \\
3 \\
22 \\
4 \\
2 \\
1 \\
27\end{array}$ & $\begin{array}{r}10 \\
2 \\
3 \\
39\end{array}$ & $\begin{array}{r}4 \\
2 \\
62 \\
48 \\
45 \\
\\
328 \\
166 \\
27 \\
25 \\
517\end{array}$ & $\begin{array}{l}2,713 \\
3,628 \\
3,082 \\
4,573 \\
7,911\end{array}$ & $\begin{array}{r}358 \\
100 \\
96 \\
649 \\
326\end{array}$ & $\begin{array}{r}759 \\
1,837 \\
548 \\
662 \\
1,164\end{array}$ & $\begin{array}{r}1 \\
9 \\
110 \\
58 \\
77 \\
70 \\
213 \\
128 \\
1,585 \\
637\end{array}$ & $\begin{array}{r}2,149 \\
1,960 \\
4,560 \\
4,43 \\
5,055\end{array}$ \\
\hline
\end{tabular}


鋼材消費數量調

-)

\begin{tabular}{|c|c|c|c|c|c|c|c|c|c|c|c|c|c|}
\hline \multicolumn{2}{|c|}{ 形 } & \multicolumn{4}{|c|}{ 䥨 } & 鋼 & \multicolumn{3}{|c|}{ 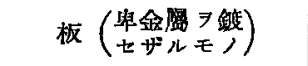 } & \multirow{2}{*}{ 線 材 } & \multirow{2}{*}{ 䥰 䈏 } & \multirow{2}{*}{ 掑 他 } & \multirow{2}{*}{ 合 䧼 } \\
\hline 出 形 & 清 形 & 工 形 & 乙形 & 其他 & 暗 & 番 物 & $\begin{array}{l}\text { 基䇣 } \\
\text { 銷板 }\end{array}$ & $\begin{array}{l}\text { 其他 }{ }^{\prime} \\
\text { 鈮 板 }\end{array}$ & 計 & & & & \\
\hline $\begin{array}{r}-10 \\
20,091 \\
18,605 \\
11,014 \\
19,186 \\
17,307\end{array}$ & \begin{tabular}{r|}
8 \\
8,317 \\
5,213 \\
4,324 \\
5,130 \\
3,720
\end{tabular} & \begin{tabular}{r|}
3,588 \\
5,368 \\
2,878 \\
1,592 \\
1,314
\end{tabular} & \begin{tabular}{r|}
346 \\
376 \\
48 \\
226 \\
175
\end{tabular} & \begin{tabular}{|r|} 
喟| \\
1,379 \\
1,39 \\
89 \\
39 \\
1,831
\end{tabular} & $\begin{array}{r}32,642 \\
30,941 \\
18,353 \\
26,173 \\
24,347\end{array}$ & $\begin{array}{r}\text { 的 } \\
2,943 \\
1,078 \\
739 \\
751 \\
594\end{array}$ & $\begin{array}{r}\text { 奛 } \\
103 \\
3 \\
111 \\
119 \\
8\end{array}$ & $\begin{array}{r}\text {. } \\
32,441 \\
30,273 \\
16,233 \\
41,867 \\
18,800\end{array}$ & $\begin{array}{r}35,487 \\
31,354 \\
17,083 \\
42,737 \\
19,402\end{array}$ & \begin{tabular}{r|} 
明 \\
1 \\
10 \\
3 \\
21 \\
7
\end{tabular} & $\begin{array}{l}\text { 嗢 } \\
3,408 \\
4,743 \\
3,035 \\
4,883 \\
7,436\end{array}$ & $\begin{array}{r}\text { 聑 } \\
3,245 \\
6,831 \\
13,666 \\
13,067 \\
11,784\end{array}$ & $\begin{array}{l}\text { 蜗 } \\
264,709 \\
274,737 \\
337,197 \\
331,168 \\
251,382\end{array}$ \\
\hline $\begin{array}{l}12,246 \\
20,175 \\
21,479 \\
29,704 \\
17,823\end{array}$ & $\begin{array}{l}2,491 \\
3,699 \\
5,256 \\
5,576 \\
5,617\end{array}$ & $\begin{array}{l}2,886 \\
4,215 \\
2,466 \\
5,335 \\
2,004\end{array}$ & \begin{tabular}{r|}
86 \\
49 \\
50 \\
123 \\
136
\end{tabular} & $\begin{array}{r}1,430 \\
295 \\
468 \\
986 \\
64\end{array}$ & $\begin{array}{l}19,139 \\
28,433 \\
29,719 \\
41,724 \\
25,644\end{array}$ & $\begin{array}{l}1,420 \\
2,786 \\
3,363 \\
3,139 \\
1,749\end{array}$ & $\begin{array}{r}8 \\
136 \\
41 \\
233 \\
27\end{array}$ & $\begin{array}{l}16,565 \\
15,254 \\
18,364 \\
17,637 \\
17,049\end{array}$ & $\begin{array}{l}17,993 \\
18,176 \\
21,768 \\
21,009 \\
18,825\end{array}$ & $\begin{array}{r}339 \\
890 \\
226 \\
2,596 \\
27,525\end{array}$ & $\begin{array}{l}2,726 \\
2,421 \\
2,856 \\
5,692 \\
4,362\end{array}$ & $\begin{array}{l}10,448 \\
12,488 \\
13,756 \\
18,452 \\
18,798\end{array}$ & $\begin{array}{l}172,425 \\
232,244 \\
212,170 \\
319,238 \\
254,922\end{array}$ \\
\hline $\begin{array}{l}31,950 \\
35,554 \\
63,714 \\
18,253 \\
31,998\end{array}$ & $\begin{array}{r}13,660 \\
8,817 \\
11,195 \\
28,147 \\
23,787\end{array}$ & $\begin{array}{l}16,509 \\
11,540 \\
15,746 \\
39,027 \\
30,254\end{array}$ & $\begin{array}{r}101 \\
59 \\
127 \\
557 \\
423\end{array}$ & $\begin{array}{r}i, 642 \\
433 \\
117 \\
556 \\
736\end{array}$ & $\begin{array}{r}63,862 \\
56,403 \\
90,899 \\
186,540 \\
187,198\end{array}$ & $\begin{array}{r}7,427 \\
1,577 \\
2,747 \\
86,155 \\
11,976\end{array}$ & $\begin{array}{r}819 \\
505 \\
1,503 \\
1,200 \\
822\end{array}$ & $\begin{array}{l}12,116 \\
13,426 \\
22,518 \\
65,902 \\
69,130\end{array}$ & $\begin{array}{r}20,362 \\
15,508 \\
26,768 \\
153,257 \\
81,928\end{array}$ & $\begin{array}{r}834 \\
1,407 \\
2,111 \\
4,525 \\
10,379\end{array}$ & $\begin{array}{l}1,025 \\
3,723 \\
1,587 \\
4,955 \\
7,125\end{array}$ & $\begin{array}{r}110 \\
1,364 \\
2,394 \\
4,028 \\
1,382\end{array}$ & $\begin{array}{l}252,870 \\
239,416 \\
399,742 \\
696,824 \\
619,076\end{array}$ \\
\hline $\begin{array}{l}03,961 \\
10,577 \\
30,372 \\
60,758 \\
47,058\end{array}$ & $\begin{array}{l}18,167 \\
21,505 \\
29,758 \\
39,584 \\
31,469\end{array}$ & $\begin{array}{l}40,471 \\
33,393 \\
45,102 \\
35,840 \\
36,519\end{array}$ & $\begin{array}{l}689 \\
479 \\
654 \\
973 \\
882\end{array}$ & $\begin{array}{r}2,629 \\
1,267 \\
614 \\
3,205 \\
17,083\end{array}$ & $\begin{array}{l}165,917 \\
167,221 \\
206,500 \\
240,360 \\
233,011\end{array}$ & $\begin{array}{l}7,568 \\
6,269 \\
4,282 \\
4,650 \\
3,205\end{array}$ & $\begin{array}{r}619 \\
298 \\
1,825 \\
2,069 \\
2,321\end{array}$ & $\begin{array}{r}57,419 \\
83,070 \\
84,787 \\
90,078 \\
114,974\end{array}$ & $\begin{array}{r}65,606 \\
89,637 \\
90,894 \\
96,797 \\
120,500\end{array}$ & $\begin{array}{r}2,900 \\
853 \\
1,202 \\
2,734 \\
1,148\end{array}$ & $\begin{array}{r}6,785 \\
11,114 \\
11,119 \\
15,526 \\
15,734\end{array}$ & $\begin{array}{r}1,252 \\
384 \\
4,518 \\
742 \\
261\end{array}$ & $\begin{array}{l}487,907 \\
620,866 \\
730,436 \\
792,442 \\
846,190\end{array}$ \\
\hline $\begin{array}{r}19,414 \\
\therefore 15,767 \\
: 25,416 \\
ن 31,541 \\
: 15,895\end{array}$ & $\begin{array}{l}1,562 \\
1,756 \\
3,997 \\
7,837 \\
5,986\end{array}$ & $\begin{array}{l}1,385 \\
1,609 \\
2,595 \\
6,245 \\
4,526\end{array}$ & $\begin{array}{l}496 \\
630 \\
831 \\
734 \\
578\end{array}$ & $\begin{array}{r}162 \\
198 \\
1,021 \\
377 \\
206\end{array}$ & $\begin{array}{l}23,019 \\
19,960 \\
33,860 \\
46,734 \\
25,191\end{array}$ & $\begin{array}{r}2,492 \\
2,918 \\
6,662 \\
648 \\
662\end{array}$ & $\begin{array}{r}180 \\
622 \\
207 \\
7 \\
47\end{array}$ & $\begin{array}{r}40,581 \\
50,520 \\
86,652 \\
128,563 \\
57,382\end{array}$ & $\begin{array}{r}43,253 \\
54,060 \\
93,521 \\
129,218 \\
58,091\end{array}$ & $\begin{array}{r}15 \\
8 \\
2 \\
11 \\
1\end{array}$ & $\begin{array}{r}2,453 \\
2,430 \\
3,600 \\
11,677 \\
13,037\end{array}$ & $\begin{array}{r}8,918 \\
4,662 \\
4,562 \\
1,514 \\
145\end{array}$ & $\begin{array}{r}90,384 \\
107,451 \\
164,602 \\
218,844 \\
117,063\end{array}$ \\
\hline $\begin{array}{r}18,291 \\
27,283 \\
46,447 \\
501,323 \\
-57,465\end{array}$ & $\begin{array}{r}5,644 \\
7,693 \\
7,821 \\
14,154 \\
15,988\end{array}$ & $\begin{array}{l}5,566 \\
6,992 \\
7,375 \\
6,322 \\
7,206\end{array}$ & $\begin{array}{l}427 \\
467 \\
725 \\
373 \\
326\end{array}$ & $\begin{array}{r}499 \\
1,061 \\
1,975 \\
2,990 \\
4,397\end{array}$ & $\begin{array}{l}30,427 \\
43,496 \\
64,343 \\
75,162 \\
85,382\end{array}$ & $\begin{array}{r}1,934 \\
2,101 \\
1,140 \\
1,735 \\
976\end{array}$ & $\begin{array}{r}41 \\
131 \\
65 \\
53 \\
5,784\end{array}$ & $\begin{array}{r}47,634 \\
76,667 \\
155,641 \\
187,744 \\
163,514\end{array}$ & $\begin{array}{r}49,609 \\
78,899 \\
156,846 \\
189,532 \\
170,274\end{array}$ & $\begin{array}{r}- \\
4 \\
10 \\
266 \\
1,541\end{array}$ & $\begin{array}{r}5,077 \\
7,721 \\
8,222 \\
10,013 \\
10,446\end{array}$ & $\begin{array}{r}119 \\
456 \\
96 \\
278 \\
270\end{array}$ & $\begin{array}{l}111,209 \\
159,236 \\
275,332 \\
329,591 \\
320,912\end{array}$ \\
\hline $\begin{array}{l}r 8,388 \\
20,180 \\
25,132 \\
32,806 \\
14,326\end{array}$ & $\begin{array}{l}3,406 \\
2,905 \\
3,164 \\
6,998 \\
3,018\end{array}$ & $\begin{array}{l}2,054 \\
2,184 \\
4,301 \\
6,967 \\
3,036\end{array}$ & $\begin{array}{r}163 \\
42 \\
108 \\
115 \\
64\end{array}$ & $\begin{array}{l}295 \\
328 \\
361 \\
228 \\
136\end{array}$ & $\begin{array}{l}24,306 \\
25,639 \\
33,066 \\
47,114 \\
20,580\end{array}$ & $\begin{array}{r}8,487 \\
8,537 \\
15,883 \\
39,960 \\
30,528\end{array}$ & $\begin{array}{l}5,923 \\
2,148 \\
6,915 \\
9,090 \\
5,663\end{array}$ & $\begin{array}{r}45,172 \\
35,711 \\
162,000 \\
144,007 \\
45,201\end{array}$ & $\begin{array}{r}59,582 \\
46,396 \\
184,798 \\
193,057 \\
81,392\end{array}$ & $\begin{array}{l}38,169 \\
38,105 \\
77,769 \\
50,362 \\
54,047\end{array}$ & $\begin{array}{r}2,797 \\
4,039 \\
4,528 \\
9,280 \\
10,191\end{array}$ & $\begin{array}{r}66,418 \\
70,116 \\
25,900 \\
127,735 \\
70,518\end{array}$ & $\begin{array}{l}264,299 \\
262,319 \\
475,546 \\
541,326 \\
312,711\end{array}$ \\
\hline $\begin{array}{l}21,943 \\
32,677 \\
41,720 \\
58,570 \\
60,094\end{array}$ & $\begin{array}{r}5,097 \\
7,844 \\
23,074 \\
19,482 \\
17,405\end{array}$ & $\begin{array}{r}4,384 \\
7,415 \\
12,168 \\
13,784 \\
15,677\end{array}$ & $\begin{array}{r}26 \\
71 \\
286 \\
350 \\
291 \\
\end{array}$ & $\begin{array}{r}420 \\
2,988 \\
1,155 \\
30,369 \\
1,176\end{array}$ & $\begin{array}{r}31,870 \\
50,995 \\
78,403 \\
122,555 \\
194,643\end{array}$ & $\begin{array}{l}20,135 \\
15,493 \\
36,642 \\
73,256 \\
32,098\end{array}$ & $\begin{array}{r}4,172 \\
8,692 \\
8,776 \\
27,252 \\
22,987 \\
\end{array}$ & $\begin{array}{r}49,919 \\
55,348 \\
78,353 \\
144,036 \\
139,753\end{array}$ & $\begin{array}{r}74,226 \\
79,533 \\
123,771 \\
244,544 \\
194,838\end{array}$ & $\begin{array}{r}50,560 \\
78,223 \\
255,968 \\
246,751 \\
257,809\end{array}$ & $\begin{array}{r}11,418 \\
5,779 \\
7,694 \\
16,318 \\
12,021\end{array}$ & $\begin{array}{r}71,092 \\
97,615 \\
84,777 \\
117,583 \\
201,285\end{array}$ & $\begin{array}{r}343,927 \\
661,636 \\
1,009,207 \\
1,003,025 \\
1,090,085\end{array}$ \\
\hline $\begin{array}{l}359 \\
321 \\
398 \\
706 \\
164\end{array}$ & $\begin{array}{l}252 \\
354 \\
153 \\
213 \\
135\end{array}$ & $\begin{array}{r}80 \\
310 \\
48 \\
146 \\
99\end{array}$ & $\begin{array}{l}- \\
- \\
I \\
-\end{array}$ & $\begin{array}{r}- \\
5 \\
31 \\
53\end{array}$ & $\begin{array}{r}691 \\
985 \\
605 \\
1,096 \\
451\end{array}$ & $\begin{array}{l}186 \\
135 \\
294 \\
974 \\
482\end{array}$ & $\begin{array}{l}5 \\
4 \\
- \\
-\end{array}$ & $\begin{array}{r}2,266 \\
1,515 \\
519 \\
455 \\
3,207\end{array}$ & $\begin{array}{r}2,457 \\
1,654 \\
813 \\
1,429 \\
3,689\end{array}$ & $\begin{array}{r}- \\
50 \\
103 \\
16 \\
54\end{array}$ & $\begin{array}{r}9,855 \\
11,077 \\
18,788 \\
19,900 \\
41,393\end{array}$ & $\begin{array}{r}7,135 \\
1,350 \\
2,861 \\
28,905 \\
1,014\end{array}$ & $\begin{array}{l}22,286 \\
17,086 \\
27,799 \\
55,833 \\
51,699\end{array}$ \\
\hline $\begin{array}{r}279 \\
343 \\
801 \\
1,087 \\
3^{\prime} 151\end{array}$ & $\begin{array}{l}120 \\
187 \\
326 \\
128 \\
216\end{array}$ & $\begin{array}{l}171 \\
263 \\
577 \\
246 \\
362\end{array}$ & $\begin{array}{r}-1 \\
60 \\
60\end{array}$ & $\begin{array}{r}2 \\
42 \\
50 \\
- \\
1\end{array}$ & $\begin{array}{r}572 \\
835 \\
1,754 \\
1,521 \\
3,790\end{array}$ & $\begin{array}{r}1,752 \\
1,817 \\
50,251 \\
13,465 \\
13,492\end{array}$ & $\begin{array}{r}7 \\
1 \\
1 \\
5 \\
1,948\end{array}$ & $\begin{array}{r}6,027 \\
11,564 \\
12,490 \\
16,922 \\
11,719\end{array}$ & $\begin{array}{r}7,779 \\
13,382 \\
62,742 \\
30,392 \\
27,159\end{array}$ & \begin{tabular}{r|}
23 \\
7 \\
7 \\
3 \\
27
\end{tabular} & $\begin{array}{l}30,830 \\
34,521 \\
58,641 \\
29,636 \\
18,765\end{array}$ & $\begin{array}{r}5,601 \\
5,271 \\
5,421 \\
426 \\
20,397\end{array}$ & $\begin{array}{r}48,941 \\
60,231 \\
132,457 \\
69,595 \\
80,619\end{array}$ \\
\hline
\end{tabular}


内地普通鋼壓延

（其

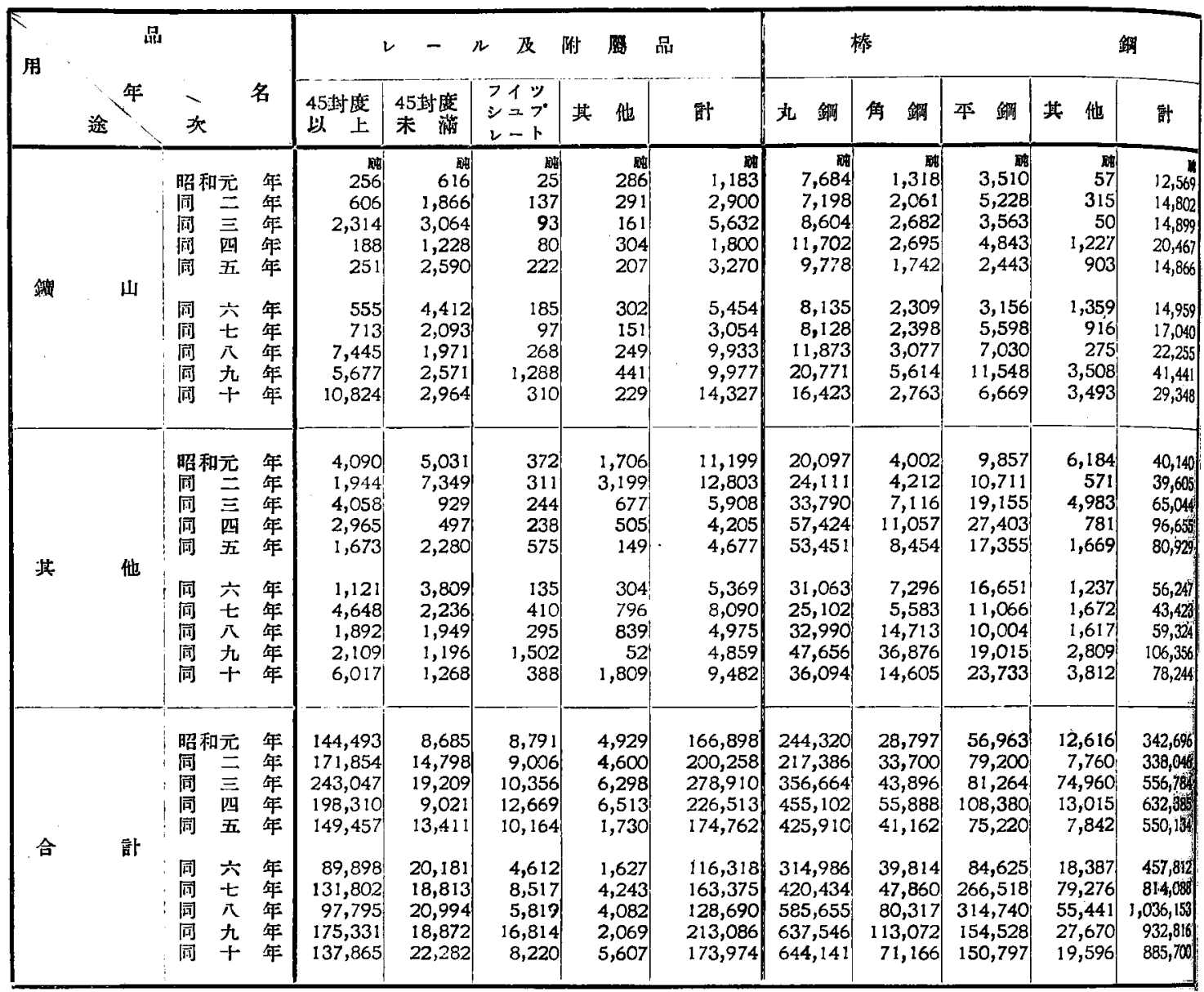

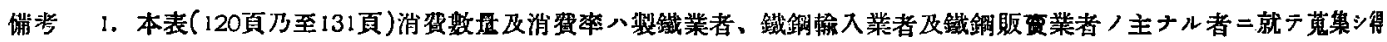

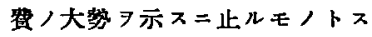

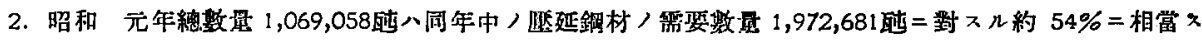

\begin{tabular}{|c|c|c|c|c|}
\hline 间 & $=$ & 年 & $"$ & $1,156,505$ 的 \\
\hline 同 & $\equiv$ & 年 & $\Rightarrow$ & 1,613,035酺 \\
\hline 网 & 四 & 年 & $"$ & $2,236,259$ 酺 \\
\hline 同 & 五. & 年 & $\Rightarrow$ & $1,613,400$ 酎 \\
\hline 流 & 六 & 年 & $"$ & $1,493,053$ 的 \\
\hline Fi. & $七$ & 年 & $\Rightarrow$ & $2,185,363$ 恉 \\
\hline 居 & 八 & 年 & $"$ & $2,691,843$ 酺 \\
\hline [i] & 九 & 年 & $"$ & 3,047,671 $\mathrm{\text {I }}$ \\
\hline & + & 年 & " & $3,145,26$ \\
\hline
\end{tabular}

$1,979,374$ 进

$2,250,319$ 䎲

$2,512,334$ 浝

$89 \%$

2,048,412藨

$79 \% "$

$1,643,387$ 通 $91 \%$

$1,946,405$ 速 " $112 \% "$

$2,663,52$ 动 " $10.1 \%$ "

$2,946,338$ 琎 " $103 \%$ "

$3,251,643$ 迹 " $97 \%$ " 


\section{鋼材消費數量調}

二)

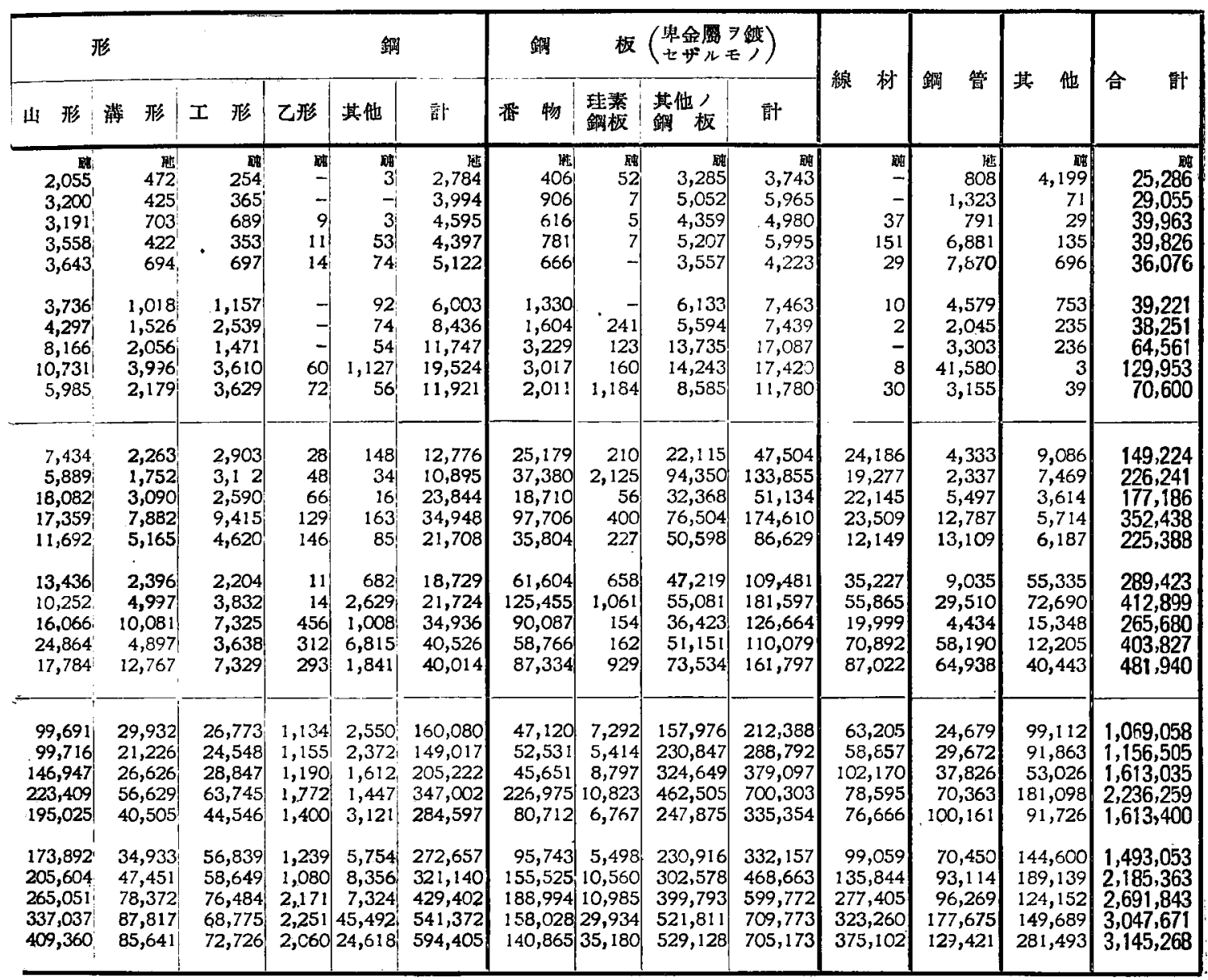

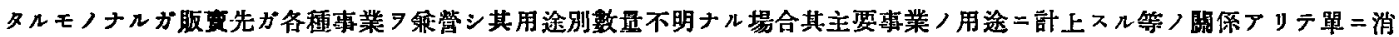


内地普通鋼崖延铜

（其

\begin{tabular}{|c|c|c|c|c|c|c|c|c|c|c|c|c|}
\hline \multirow{2}{*}{ 用 } & & & \multicolumn{5}{|c|}{ レ 一 及 及附愿品 } & \multicolumn{4}{|c|}{ 棒 } & 銷 \\
\hline & & & $\begin{array}{l}\text { 45封噔 } \\
\text { 以 王 }\end{array}$ & 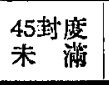 & $\begin{array}{l}\text { フィ\% } \\
8=70 \\
2-1\end{array}$ & 其 他 & 鄚 & 丸 鐦 & 仵 䥨 & 平 銅 & 其 他 & 壾 \\
\hline 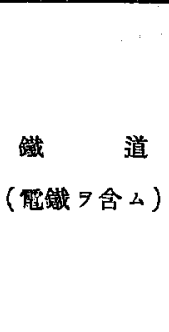 & 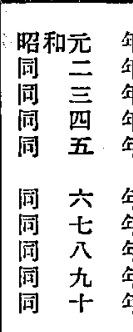 & $\begin{array}{l}\text { 解 } \\
\text { 年 } \\
\text { 年 } \\
\text { 年 } \\
\text { 年 } \\
\text { 年 } \\
\text { 年 } \\
\text { 年 } \\
\text { 年 } \\
\text { 年 }\end{array}$ & $\begin{array}{l}96.1 \\
98.4 \\
95.1 \\
96.7 \\
96.7 \\
96.3 \\
94.9 \\
87.9 \\
94.4 \\
85.2\end{array}$ & \begin{tabular}{r|}
$26 \%$ \\
23.0 \\
40.9 \\
30.4 \\
15.3 \\
9.9 \\
8.6 \\
11.1 \\
4.0 \\
13.7
\end{tabular} & $\begin{array}{r}9 \% \\
93.8 \\
93.6 \\
91.8 \\
94.5 \\
88.4 \\
77.8 \\
64.4 \\
77.5 \\
79.7 \\
71.1\end{array}$ & \begin{tabular}{l|}
56.3 \\
20.6 \\
67.5 \\
82.3 \\
50.0 \\
\\
37.4 \\
56.9 \\
49.6 \\
28.3 \\
34.4
\end{tabular} & $\begin{array}{l}90.6 \\
91.1 \\
90.8 \\
90.6 \\
93.5 \\
69.5 \\
79.7 \\
82.4 \\
73.7 \\
84.6 \\
73.7\end{array}$ & $\begin{array}{l}9.3 \\
4.5 \\
3.5 \\
3.2 \\
4.9 \\
4.9 \\
4.6 \\
4.0 \\
2.9 \\
2.4\end{array}$ & $\begin{array}{l}20.5 \\
12.2 \\
17.3 \\
18.8 \\
13.9 \\
11.1 \\
13.6 \\
20.2 \\
16.9 \\
10.2\end{array}$ & $\begin{array}{r}13.9 \\
6.3 \\
6.7 \\
6.2 \\
6.3 \\
\\
10.3 \\
3.1 \\
2.9 \\
7.5 \\
5.6\end{array}$ & $\begin{array}{r}10.6 \\
2.1 \\
9.3 \\
3.8 \\
7.2 \\
6.9 \\
1.2 \\
0.8 \\
0.8 \\
3.8\end{array}$ & $\begin{array}{r}.9 \\
11.0 \\
5.6 \\
5.8 \\
5.8 \\
8.5 \\
6.3 \\
4.3 \\
4.7 \\
5.3 \\
3.6\end{array}$ \\
\hline $\begin{array}{l}\text { 上本建築 } \\
\text { 鐵，骨揹造 }\end{array}$ & 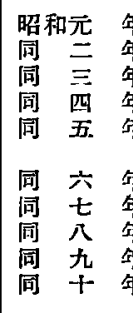 & $\begin{array}{l}\text { 年 } \\
\text { 年 } \\
\text { 年 } \\
\text { 年 } \\
\text { 非 } \\
\text { 等 } \\
\text { 年 } \\
\text { 年 } \\
\text { 乍 } \\
\text { 年 }\end{array}$ & $\begin{array}{l}0.3 \\
- \\
1.3 \\
1.1 \\
1.2 \\
0.9 \\
0.5 \\
1.1 \\
0.4 \\
0.6\end{array}$ & $\begin{array}{r}8.2 \\
13.8 \\
30.4 \\
45.2 \\
45.6 \\
42.0 \\
66.4 \\
65.7 \\
70.3 \\
65.2\end{array}$ & \begin{tabular}{r|}
0.8 \\
1.1 \\
3.8 \\
2.5 \\
3.5 \\
14.3 \\
29.2 \\
12.6 \\
2.8 \\
15.7
\end{tabular} & \begin{tabular}{r|r}
1.3 & 1.8 \\
18.6 & \\
4.6 & \\
23.7 & \\
21.3 & \\
17.7 & 16.5 \\
39.0 & \\
20.4 &
\end{tabular} & \begin{tabular}{r|}
0.7 \\
1.1 \\
3.8 \\
3.1 \\
5.0 \\
8.8 \\
10.0 \\
12.6 \\
7.1 \\
10.2
\end{tabular} & $\begin{array}{l}58.6 \\
58.8 \\
65.8 \\
64.6 \\
67.6 \\
63.8 \\
69.4 \\
61.3 \\
60.0 \\
66.8\end{array}$ & \begin{tabular}{l|}
21.7 \\
27.7 \\
22.5 \\
18.2 \\
24.9 \\
20.6 \\
22.2 \\
14.9 \\
10.2 \\
17.2
\end{tabular} & \begin{tabular}{r|}
21.4 \\
26.0 \\
23.9 \\
28.9 \\
29.4 \\
24.6 \\
11.3 \\
8.7 \\
16.3 \\
8.8
\end{tabular} & \begin{tabular}{r|}
29.9 \\
12.2 \\
2.0 \\
10.3 \\
26.3 \\
28.7 \\
3.5 \\
2.9 \\
7.7 \\
9.2
\end{tabular} & $\begin{array}{r}51.4 \\
41.2 \\
38,6 \\
45.2 \\
51.7\end{array}$ \\
\hline 船 & 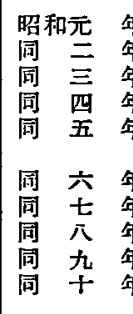 & $\begin{array}{l}\text { 年 } \\
\text { 年 } \\
\text { 年 } \\
\text { 年 } \\
\text { 年 } \\
\text { 年 } \\
\text { 年 } \\
\text { 年 } \\
\text { 年 } \\
\text { 年 }\end{array}$ & \begin{tabular}{r|}
0.4 \\
- \\
0.1 \\
0.3 \\
0.1 \\
- \\
0.5 \\
1.1 \\
0.4 \\
0.9
\end{tabular} & $\begin{array}{l}0.4 \\
0.5 \\
7.0 \\
0.8 \\
0.2 \\
2.5 \\
0.9 \\
3.6 \\
2.3 \\
0.7\end{array}$ & \begin{tabular}{r|}
0.4 \\
- \\
0.3 \\
0.1 \\
0.2 \\
0.3 \\
0.1 \\
0.5 \\
1.5
\end{tabular} & \begin{tabular}{r|}
1.8 \\
- \\
- \\
0.5 \\
4.3 \\
3.1 \\
2.9 \\
6.2 \\
8.4 \\
4.1
\end{tabular} & $\begin{array}{l}c .5 \\
- \\
0.5 \\
0.3 \\
0.1 \\
0.5 \\
0.5 \\
1.7 \\
0.6 \\
1.0\end{array}$ & $\begin{array}{l}2.7 \\
4.8 \\
4.5 \\
3.8 \\
2.7 \\
4.5 \\
4.0 \\
5.3 \\
4.8 \\
4.5\end{array}$ & $\begin{array}{l}5.9 \\
4.5 \\
6.9 \\
7.0 \\
5.5 \\
7.5 \\
7.0 \\
4.2 \\
5.1 \\
5.7\end{array}$ & \begin{tabular}{r|}
5.5 \\
12.1 \\
7.7 \\
6.6 \\
8.0 \\
8.2 \\
2.7 \\
2.3 \\
7.8 \\
10.8
\end{tabular} & \begin{tabular}{r|}
3.3 \\
62.2 \\
2.9 \\
5.3 \\
5.2 \\
7.5 \\
.0 \\
0.7 \\
3.5 \\
17.3 \\
11.3
\end{tabular} & $\begin{array}{l}5.5 \\
3.4 \\
4.2 \\
5.7 \\
5.8\end{array}$ \\
\hline 機㭜鐵工業 & $\begin{array}{l}\text { 昭和元 } \\
\text { 同 } \\
\text { 同 } \\
\text { 同 } \\
\text { 同 } \\
\text { 西 } \\
\text { 五 } \\
\text { 同 六 } \\
\text { 同 七 } \\
\text { 同 } \\
\text { 同 } \\
\text { 点 } \\
\text { 同 } \\
\text { 十 }\end{array}$ & $\begin{array}{l}\text { 年 } \\
\text { 年 } \\
\text { 年 } \\
\text { 年 } \\
\text { 年 } \\
\text { 年 } \\
\text { 年 } \\
\text { 年 } \\
\text { 年 } \\
\text { 年 }\end{array}$ & $\begin{array}{l}0.2 \\
0.1 \\
0.9 \\
0.3 \\
0.7 \\
0.9 \\
0.1 \\
0.3 \\
0.4 \\
0.8\end{array}$ & $\begin{array}{l}0.2 \\
0.4 \\
0.7 \\
4.1 \\
1.3 \\
3.5 \\
0.6 \\
0.8 \\
3.4 \\
1.2\end{array}$ & $\begin{array}{l}0.5 \\
0.3 \\
1.1 \\
0.2 \\
0.1 \\
0.2 \\
0.2 \\
0.1 \\
0.4 \\
2.9\end{array}$ & \begin{tabular}{l|}
0.2 \\
1.7 \\
0.5 \\
0.2 \\
1.4 \\
0.3 \\
0.1 \\
0.1 \\
0.4 \\
3.7
\end{tabular} & \begin{tabular}{l|}
0.2 \\
0.2 \\
0.9 \\
0.4 \\
0.8 \\
1.4 \\
0.2 \\
0.4 \\
0.7 \\
1.1
\end{tabular} & $\begin{array}{r}17.5 \\
16.8 \\
13.3 \\
12.6 \\
9.0 \\
13.8 \\
13.3 \\
21.3 \\
20.9 \\
17.0\end{array}$ & $\begin{array}{l}32.3 \\
36.8 \\
30.8 \\
30.3 \\
30.1 \\
\\
36.0 \\
39.6 \\
38.4 \\
29.5 \\
42.2\end{array}$ & \begin{tabular}{l|}
34.8 \\
35.0 \\
33.1 \\
27.7 \\
29.1 \\
\\
32.6 \\
75.9 \\
80.5 \\
48.2 \\
53.9
\end{tabular} & $\begin{array}{r}6.8 \\
11.9 \\
79.1 \\
64.7 \\
27.5 \\
42.4 \\
91.0 \\
89.5 \\
45.7 \\
35.1\end{array}$ & $\begin{array}{r}21.2 \\
22.9 \\
26.4 \\
17.9 \\
7.2 \\
20 \\
20 \\
44 \\
44 \\
21.2 \\
25.9\end{array}$ \\
\hline $\begin{array}{l}\text { 石 } \\
\text { 瓦 } \\
\text { 水 }\end{array}$ & 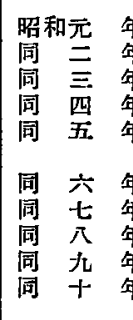 & $\begin{array}{l}\text { 年 } \\
\text { 年 } \\
\text { 年 } \\
\text { 年 } \\
\text { 年 } \\
\text { 年 } \\
\text { 年 } \\
\text { 年 } \\
\text { 年 } \\
\text { 年 }\end{array}$ & $\begin{array}{r}\overline{-} \\
\overline{-} \\
\overline{-} \\
\overline{-} \\
0.3\end{array}$ & $\begin{array}{r}- \\
0.3 \\
0.4 \\
0.3 \\
1.4 \\
0.5 \\
0.1 \\
0.1 \\
0.2\end{array}$ & $\begin{array}{r}- \\
- \\
- \\
- \\
0.5 \\
- \\
- \\
\overline{0}\end{array}$ & $\begin{array}{r}- \\
- \\
- \\
0.6 \\
- \\
0.1 \\
1.0\end{array}$ & $\begin{array}{r}- \\
- \\
0.2 \\
- \\
- \\
0.3 \\
0.1 \\
- \\
- \\
0.3\end{array}$ & $\begin{array}{l}0.5 \\
0.7 \\
1.1 \\
0.6 \\
1.0\end{array}$ & $\begin{array}{l}0.7 \\
0.9 \\
0.2 \\
0.7 \\
0.3\end{array}$ & $\begin{array}{l}1.0 \\
0.5 \\
0.7 \\
0.9 \\
0.8\end{array}$ & $\begin{array}{r}0.1 \\
0.5 \\
0.5 \\
1.0\end{array}$ & $\begin{array}{l}0.6 \\
0.6 \\
0.8 \\
0.7 \\
0.2\end{array}$ \\
\hline
\end{tabular}




\section{材用途別消費率調}

-)

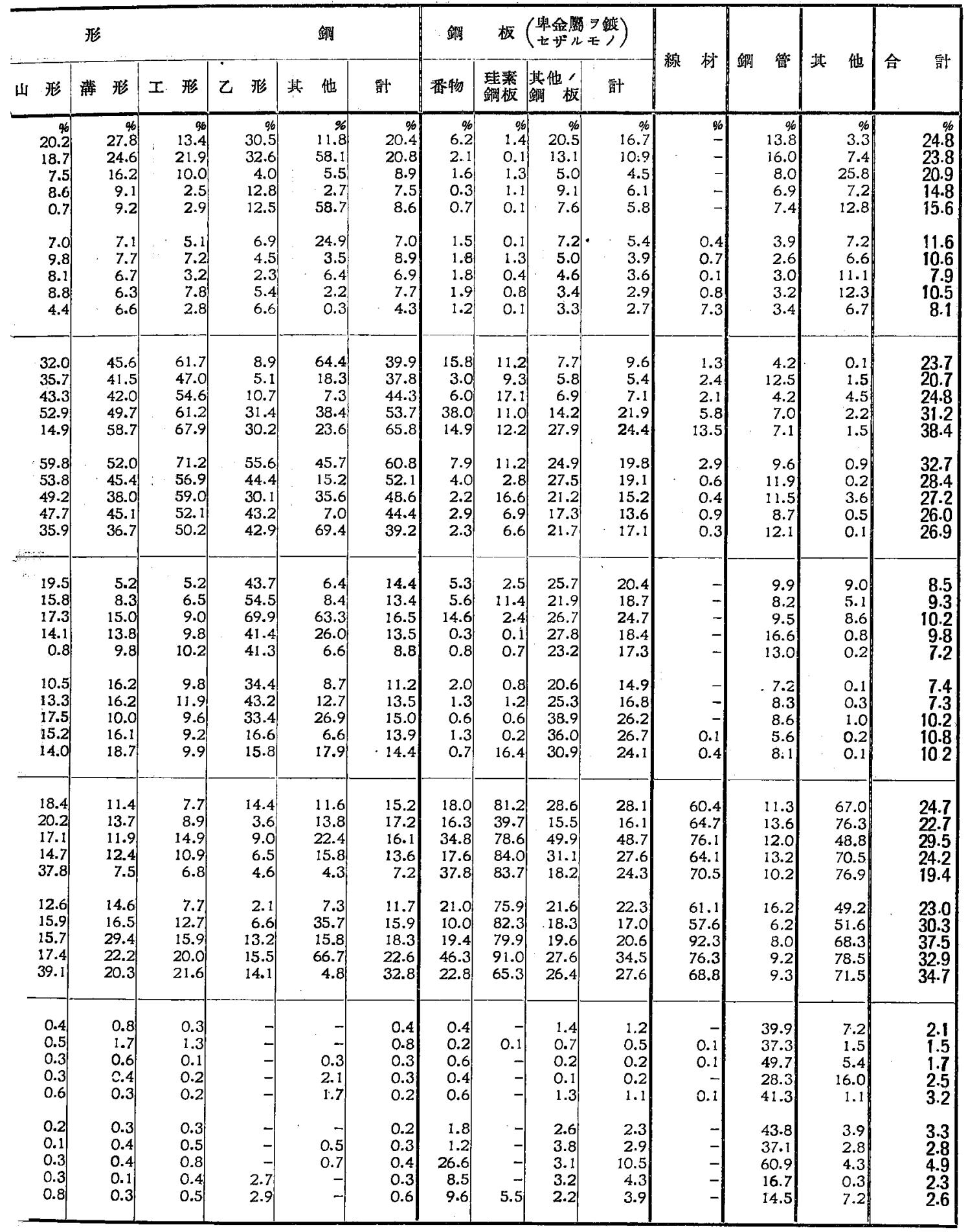


內地普通鋼壓延鋼

(其

\begin{tabular}{|c|c|c|c|c|c|c|c|c|c|c|c|c|c|}
\hline \multirow{2}{*}{\multicolumn{2}{|c|}{ 用 }} & & & \multicolumn{2}{|c|}{$v$} & \multirow{2}{*}{ 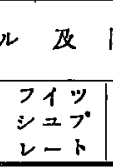 } & \multirow{2}{*}{$\frac{\text { 附 風 }}{\text { 其 他 }}$} & \multirow[b]{2}{*}{ 計 } & \multicolumn{2}{|c|}{ 栯 } & \multicolumn{3}{|c|}{ 銅 } \\
\hline & & 次 & & $\begin{array}{l}\text { 45封度 } \\
\text { 以上 }\end{array}$ & $\begin{array}{l}\text { 45䞑度 } \\
\text { 未湤 }\end{array}$ & & & & 丸 炡 & 角 䥨 & 平 鍓 & 其 他 & 計 \\
\hline 䥀 & 山 & 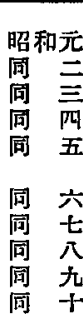 & $\begin{array}{l}\text { 年 } \\
\text { 年 } \\
\text { 年 } \\
\text { 年 } \\
\text { 年 } \\
\text { 年 } \\
\text { 年 } \\
\text { 年 } \\
\text { 年 } \\
\text { 年 }\end{array}$ & \begin{tabular}{l|}
$q$ \\
0.2 \\
0.4 \\
0.9 \\
0.1 \\
0.2 \\
0.6 \\
0.5 \\
7.6 \\
3.2 \\
7.8
\end{tabular} & $\begin{array}{r}7.1 \\
12.6 \\
15.9 \\
13.6 \\
19.3 \\
21.8 \\
11.1 \\
9.4 \\
13.6 \\
13,3\end{array}$ & $\begin{array}{r}0.3 \\
0.5 \\
1.5 \\
0.9 \\
0.6 \\
2.2 \\
\\
4.0 \\
1.1 \\
4.6 \\
7.7 \\
3.8\end{array}$ & \begin{tabular}{r|}
$9 \%$ \\
5.8 \\
6.3 \\
2.6 \\
4.7 \\
12.0 \\
\\
18.6 \\
3.6 \\
6.1 \\
21.3 \\
4.1
\end{tabular} & $\begin{array}{l}0.7 \\
1.5 \\
2.0 \\
0.8 \\
1.9 \\
4.7 \\
1.9 \\
7.7 \\
4.7 \\
8.2\end{array}$ & $\begin{array}{l}0 \% \\
3.1 \\
3.3 \\
2.4 \\
2.6 \\
2.3 \\
\\
2.6 \\
1.9 \\
2.0 \\
3.2 \\
2.5\end{array}$ & $\begin{array}{l}\% \\
4.6 \\
6.1 \\
6.1 \\
4.8 \\
4.2 \\
5.8 \\
5.0 \\
3.8 \\
5.0 \\
3.9\end{array}$ & $\begin{array}{l}6.2 \\
6.6 \\
4.4 \\
4.4 \\
3.3 \\
\\
3.7 \\
2.1 \\
2.2 \\
7.5 \\
4.4\end{array}$ & $\begin{array}{r}0 . \\
0.4 \\
4.1 \\
0.1 \\
9.4 \\
11.5 \\
7.4 \\
1.2 \\
-12.7 \\
17.8\end{array}$ & $\begin{array}{r}3 \\
3.7 \\
4.4 \\
2.7 \\
3.2 \\
1.8\end{array}$ \\
\hline & 他 & 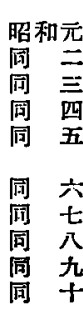 & $\begin{array}{l}\text { 年 } \\
\text { 年 } \\
\text { 年 } \\
\text { 年 } \\
\text { 年 } \\
\text { 年 } \\
\text { 年 } \\
\text { 年 } \\
\text { 年 } \\
\text { 年 }\end{array}$ & $\begin{array}{l}2.8 \\
1.1 \\
1.7 \\
1.5 \\
1.1 \\
1.3 \\
3.5 \\
2.0 \\
1.2 \\
4.4\end{array}$ & \begin{tabular}{r|}
58.0 \\
49.7 \\
4.8 \\
5.5 \\
17.0 \\
18.9 \\
11.9 \\
9.3 \\
6.3 \\
5.7
\end{tabular} & $\begin{array}{l}4.2 \\
3.5 \\
2.4 \\
1.9 \\
5.7 \\
\\
3.0 \\
4.8 \\
5.1 \\
8.9 \\
4.7\end{array}$ & \begin{tabular}{r|}
34.6 \\
69.6 \\
10.8 \\
7.7 \\
8.6 \\
\\
18.7 \\
18.8 \\
21.5 \\
2.5 \\
32.3
\end{tabular} & $\begin{array}{l}6.8 \\
6.4 \\
2.0 \\
1.9 \\
2.7 \\
4.6 \\
4.9 \\
3.9 \\
2.3 \\
5.5\end{array}$ & $\begin{array}{r}8.3 \\
11.1 \\
9.4 \\
12.6 \\
12.5 \\
9.8 \\
5.9 \\
5.6 \\
7.5 \\
5.6\end{array}$ & $\begin{array}{l}13.8 \\
12.4 \\
16.2 \\
19.8 \\
20.6 \\
18.3 \\
11.7 \\
18.3 \\
32.6 \\
20.5\end{array}$ & \begin{tabular}{r|}
17.2 \\
13.5 \\
23.5 \\
25.3 \\
23.1 \\
\\
19.7 \\
4.1 \\
3.2 \\
12.3 \\
15.7
\end{tabular} & $\begin{array}{r}49.0 \\
7.4 \\
6.6 \\
6.0 \\
21.3 \\
\\
6.7 \\
2.1 \\
3.0 \\
10.1 \\
19.5\end{array}$ & \begin{tabular}{r|}
11.7 \\
11.7 \\
11.7 \\
15.3 \\
7.6 \\
12.3 \\
5.4 \\
5.7 \\
11.4 \\
8.8
\end{tabular} \\
\hline 合 & 新 & $\begin{array}{l}\text { 昭和元 } \\
\text { 同 } \\
\text { 同 } \\
\text { 同 品 } \\
\text { 同 五 } \\
\text { 同 六 } \\
\text { 同 } \\
\text { 同 } \\
\text { 同 九 } \\
\text { 同 十 }\end{array}$ & $\begin{array}{l}\text { 年 } \\
\text { 年 } \\
\text { 年 } \\
\text { 年 } \\
\text { 年 } \\
\text { 年 } \\
\text { 年 } \\
\text { 年 } \\
\text { 年 } \\
\text { 年 }\end{array}$ & $\begin{array}{l}100.0 \\
100.0 \\
100.0 \\
100.0 \\
100.0 \\
100.0 \\
100.0 \\
100.0 \\
100.0 \\
100.0\end{array}$ & $\begin{array}{l}100.0 \\
100.0 \\
100.0 \\
100.0 \\
100.0 \\
100.0 \\
100.0 \\
100.0 \\
100.0 \\
100.0\end{array}$ & $\begin{array}{l}100.0 \\
100.0 \\
100.0 \\
100.0 \\
100.0 \\
100.0 \\
100.0 \\
100.0 \\
100.0 \\
100.0\end{array}$ & $\begin{array}{l}100.0 \\
100.0 \\
100.0 \\
100.0 \\
100.0 \\
100.0 \\
100.0 \\
100.0 \\
100.0 \\
100.0\end{array}$ & $\begin{array}{l}100.0 \\
100.0 \\
100.0 \\
100.0 \\
100.0 \\
100.0 \\
100.0 \\
100.0 \\
100.0 \\
100.0\end{array}$ & $\begin{array}{l}100.0 \\
100.0 \\
100.0 \\
100.0 \\
100.0 \\
100.0 \\
100.0 \\
100.0 \\
100.0 \\
100.0\end{array}$ & $\begin{array}{l}100.0 \\
100.0 \\
100.0 \\
100.0 \\
100.0 \\
100.0 \\
100.0 \\
100.0 \\
100.0 \\
100.0\end{array}$ & $\begin{array}{l}100.0 \\
100.0 \\
100.0 \\
100.0 \\
100.0 \\
100.0 \\
100.0 \\
100.0 \\
100.0 \\
100.0\end{array}$ & $\begin{array}{l}100.0 \\
100.0 \\
100.0 \\
100.0 \\
100.0 \\
100.0 \\
100.0 \\
100.0 \\
100.0 \\
100.0\end{array}$ & $\begin{array}{l}100.0 \\
100.0 \\
100.0 \\
100.0 \\
100.0 \\
100.0 \\
100.0 \\
100.0 \\
100.0 \\
100.0\end{array}$ \\
\hline
\end{tabular}




\section{材用途別消費率調}

二)

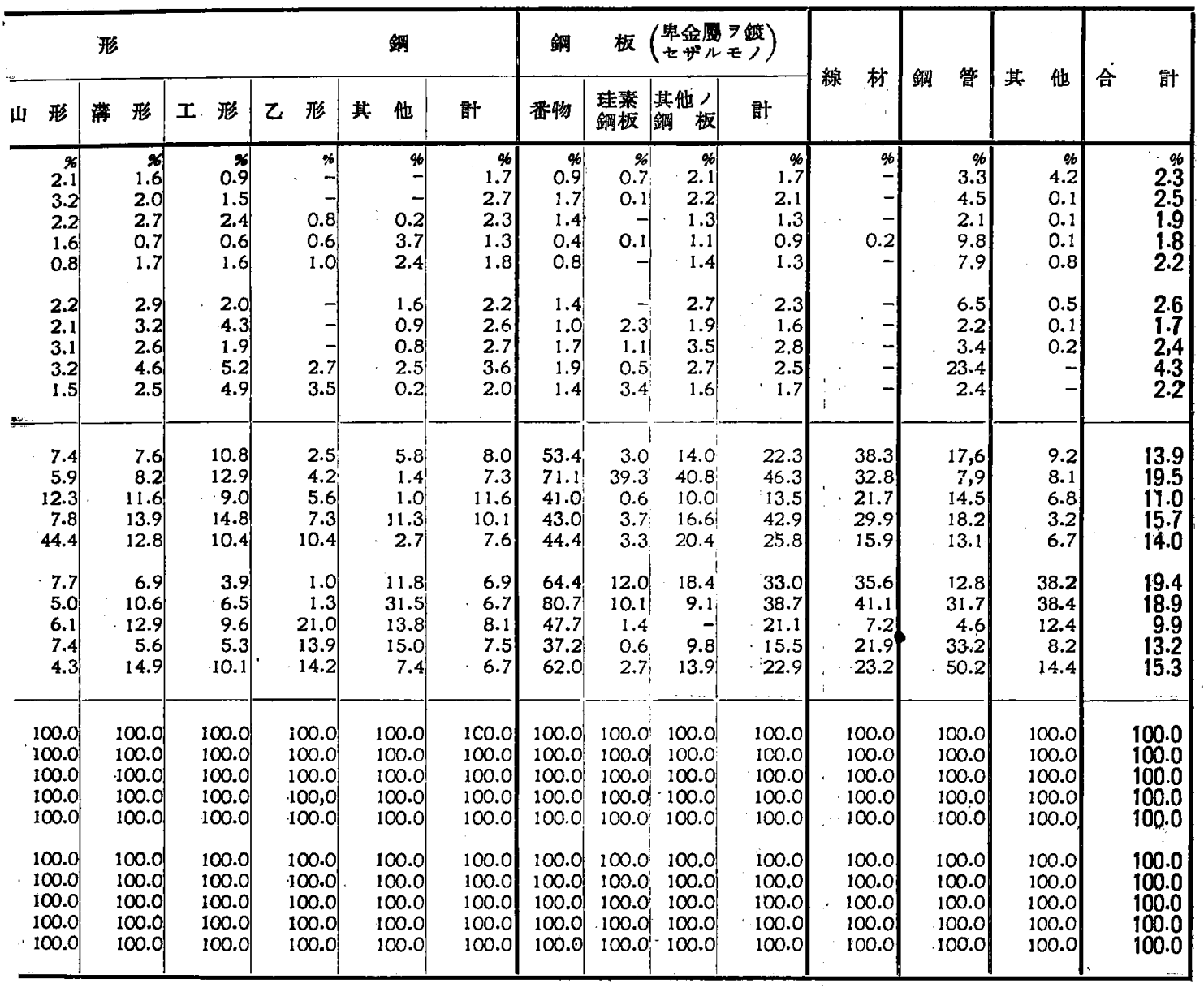


内地晋通鋼壓延

(其

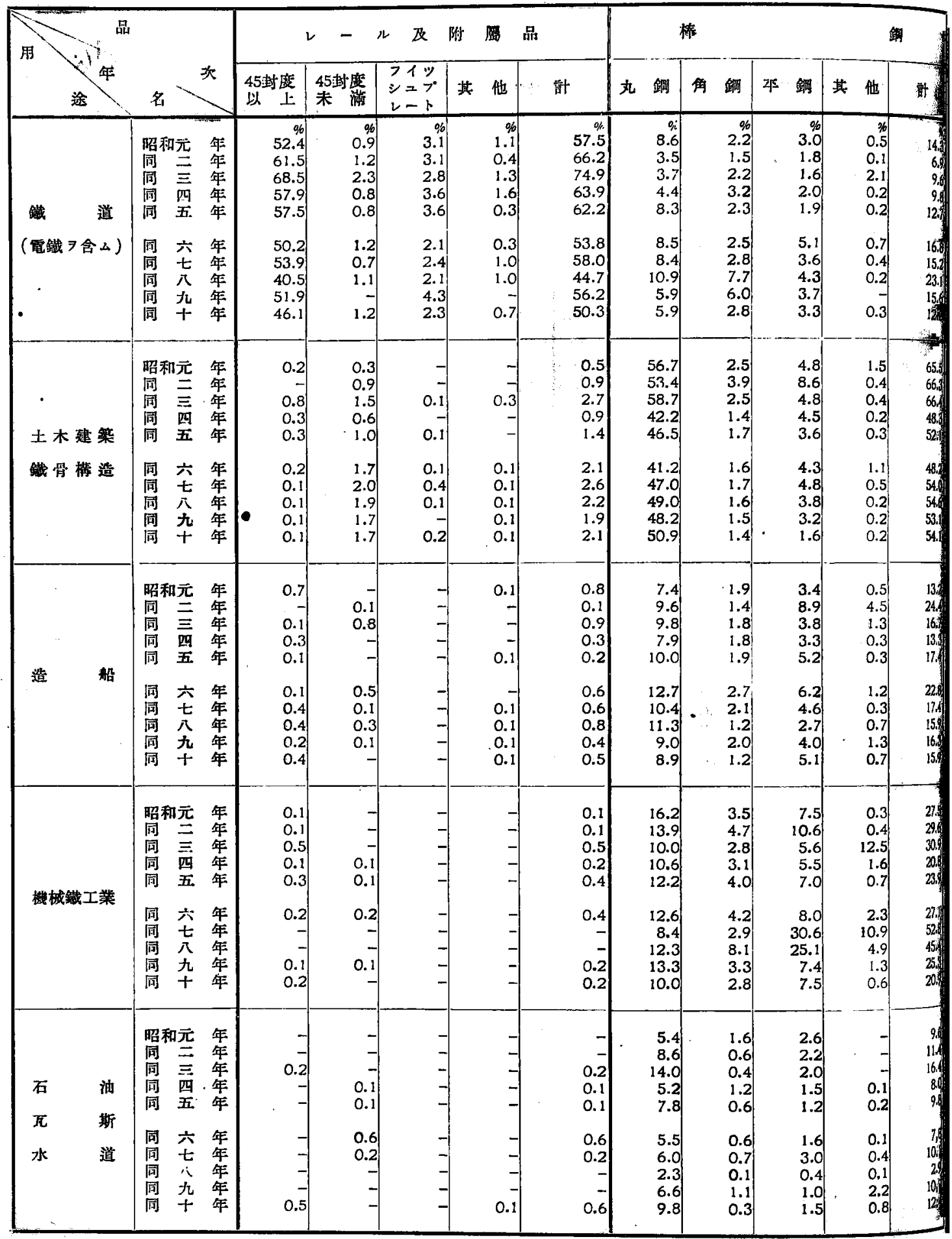




\section{材品種別消費率調}

-)

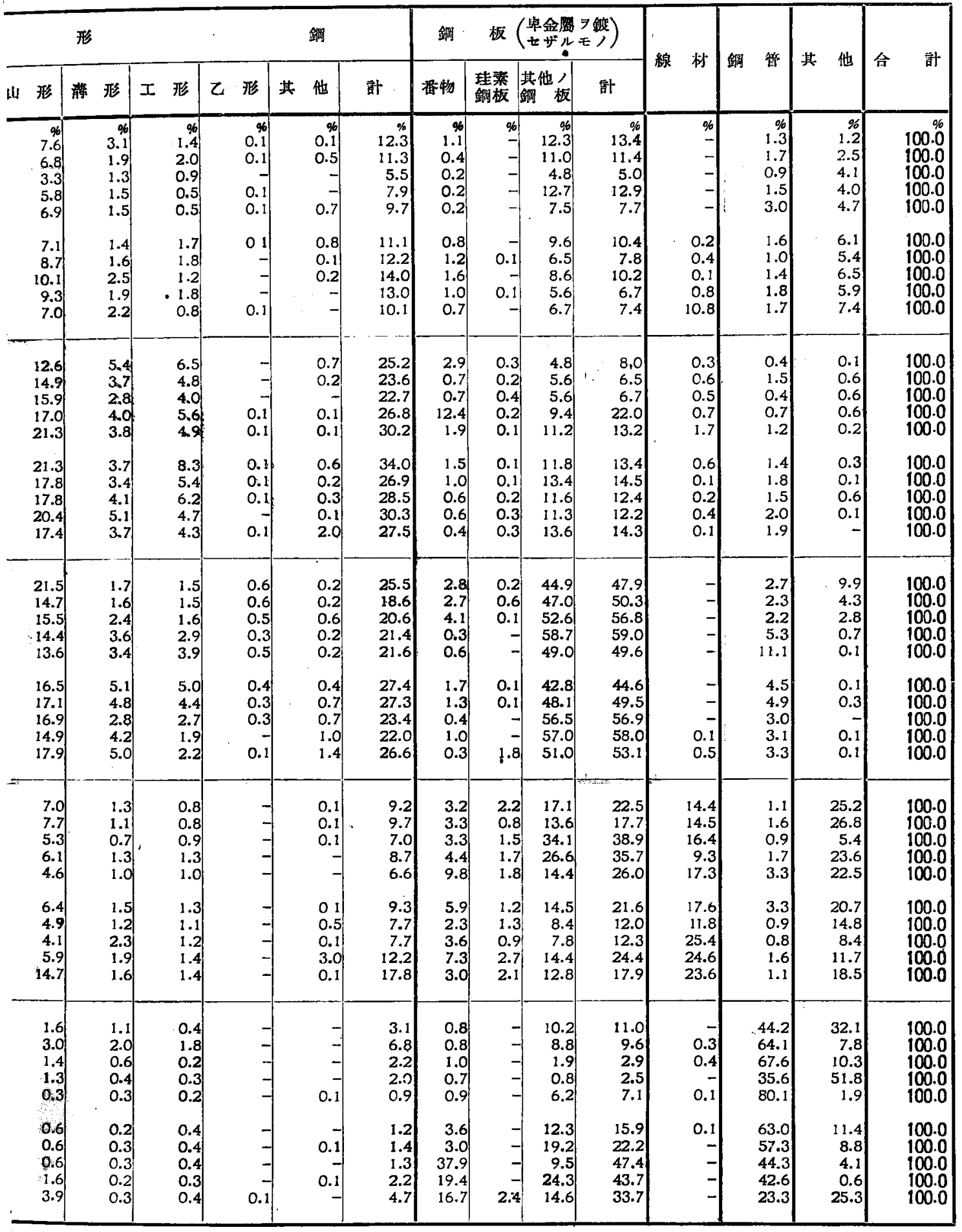


內地普通鋼壓延銅

(其

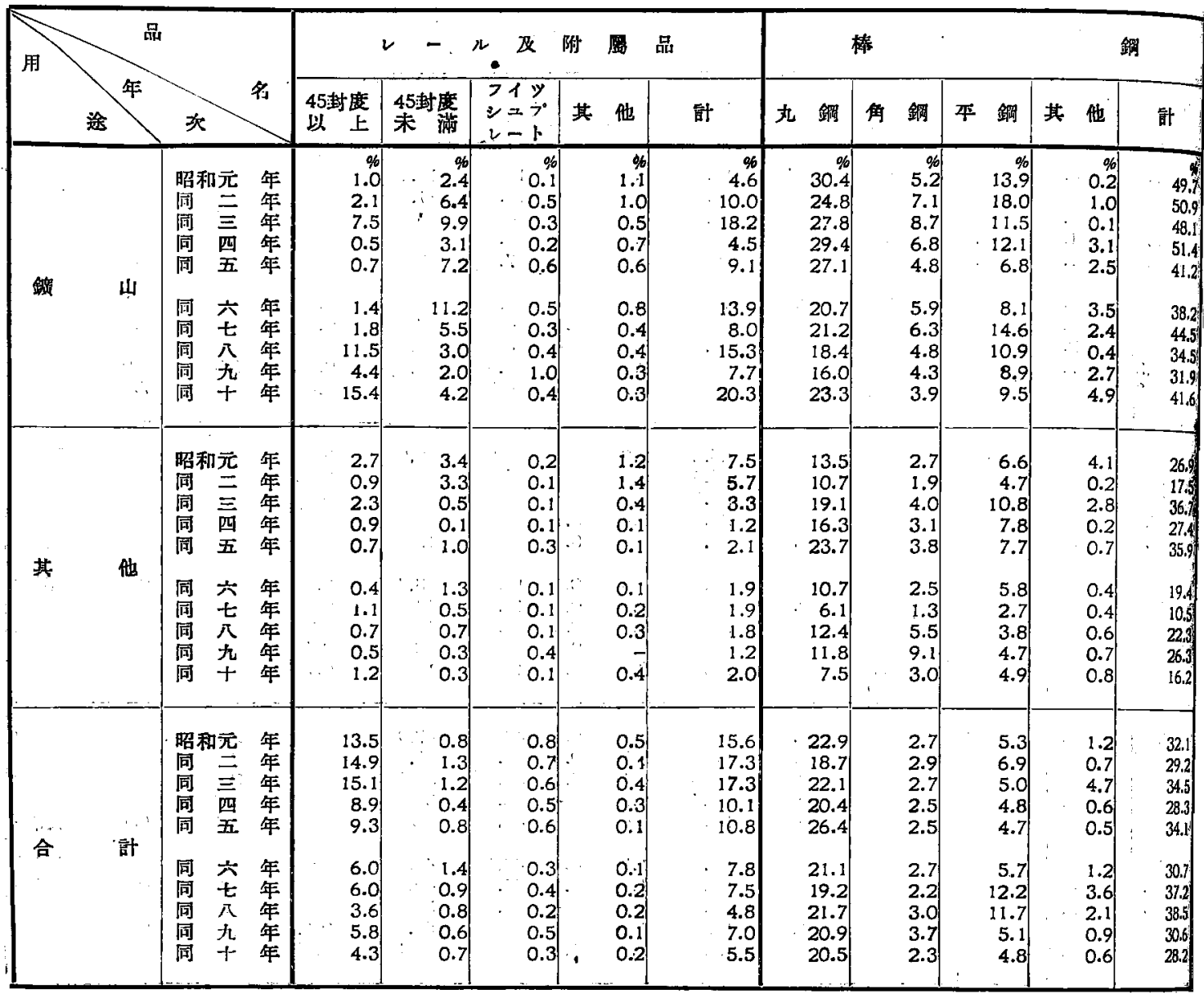


材品種別消費率調

二)

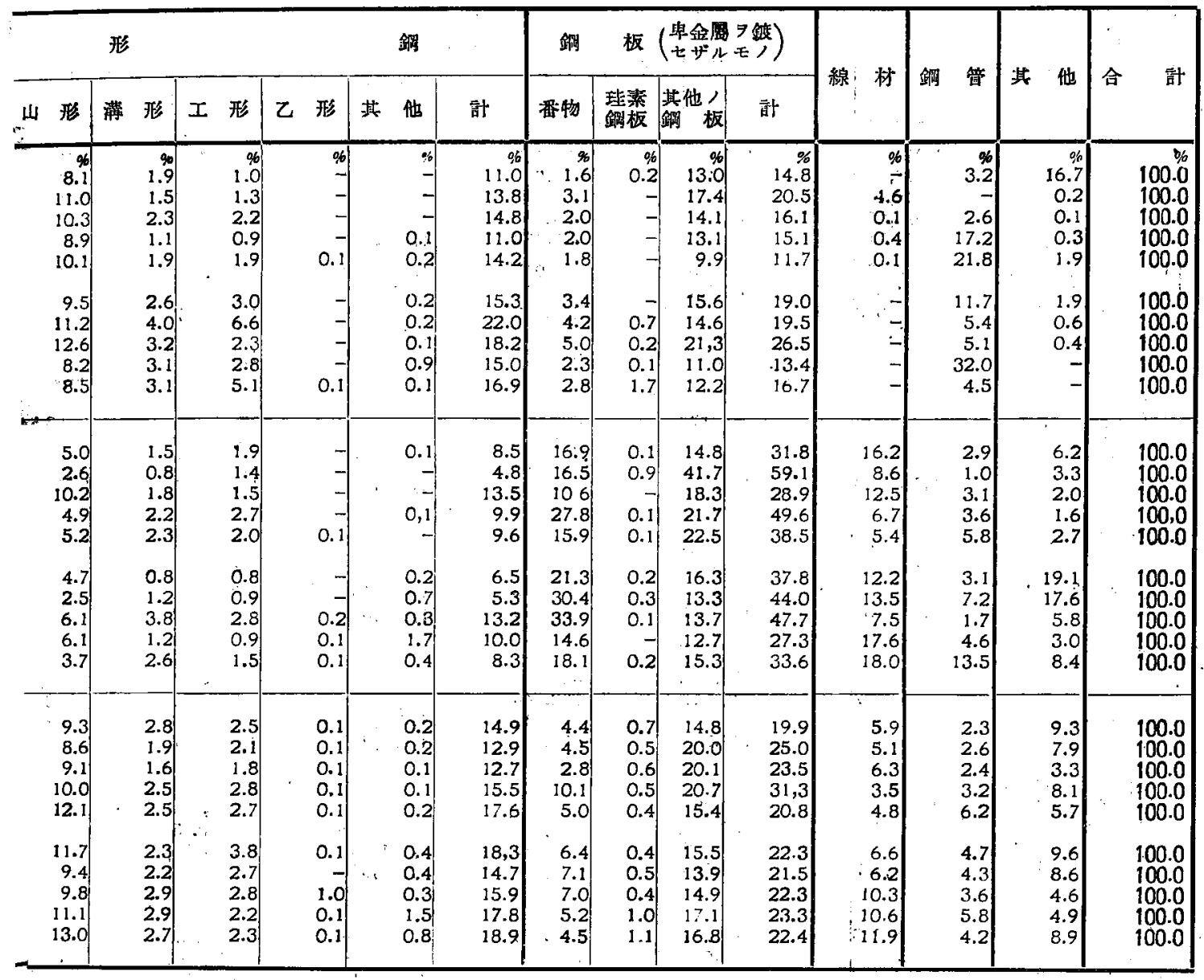




\section{内地主要製鐵所}

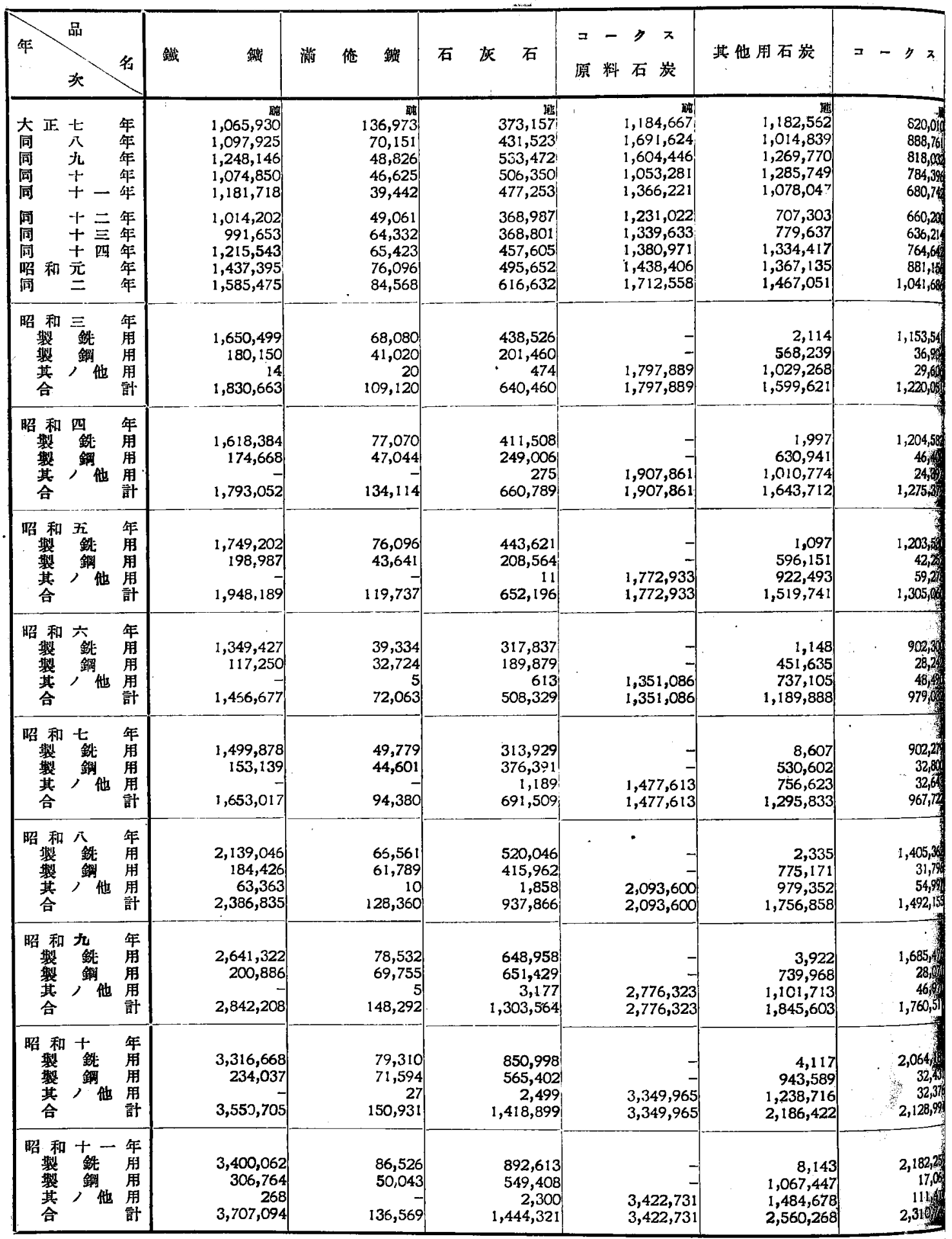




\section{原料使用額調}

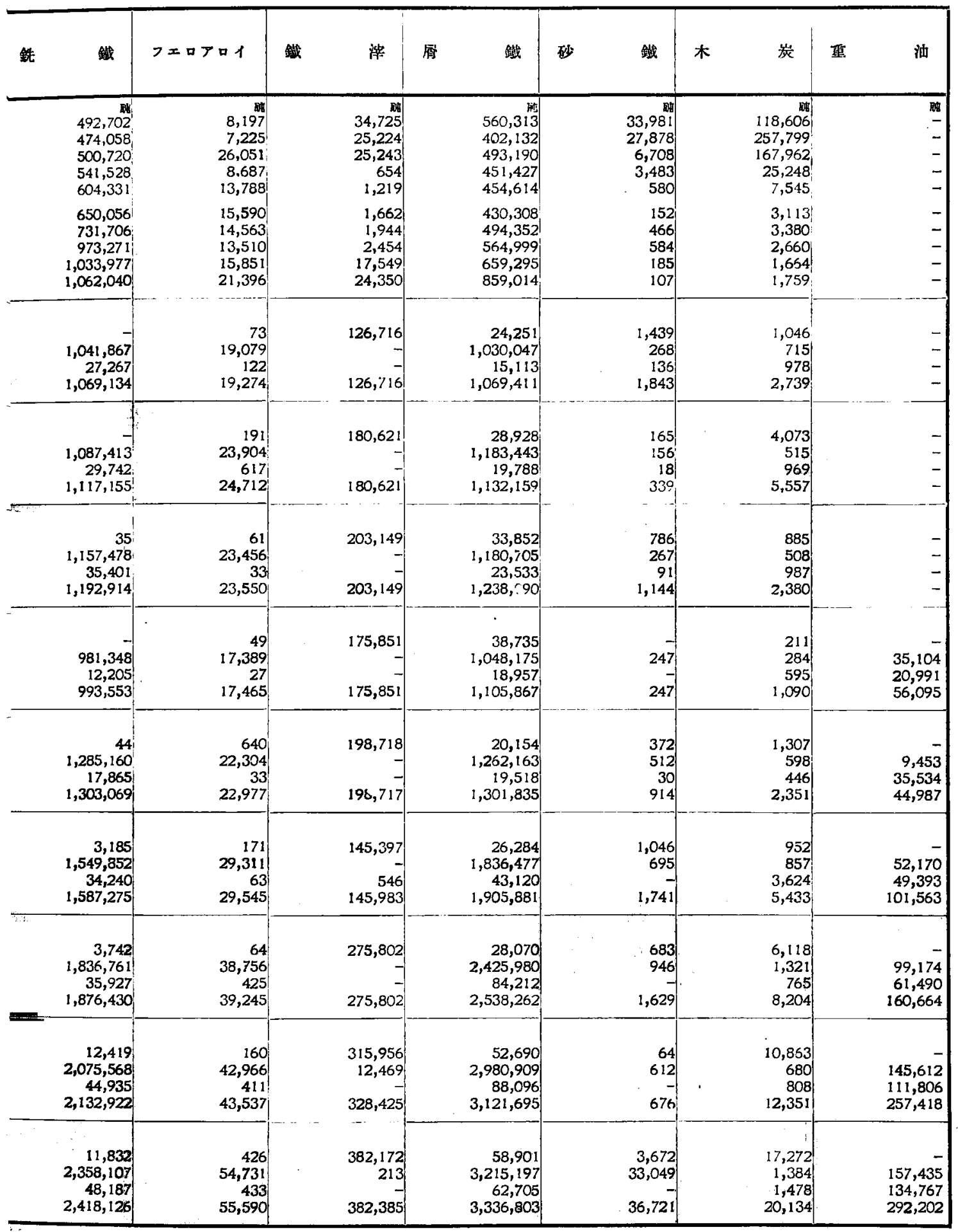


内地 鐵、銅

\begin{tabular}{|c|c|c|c|c|c|c|c|c|c|c|c|c|c|c|c|}
\hline 品年 & 次 & 帅 & 月: & 月 & 月 & 月 & 月 & 月 & 七 & 八 & 九 & + & 十一月 & 十二月 & 平 斯 \\
\hline 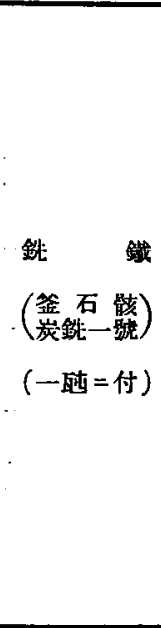 & 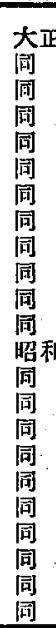 & 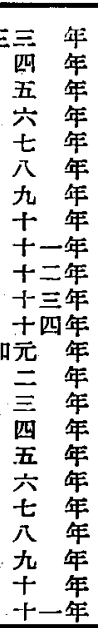 & $\begin{array}{r}r \\
57 \\
67 \\
100 \\
328 \\
228 \\
143 \\
105 \\
70 \\
67 \\
66 \\
61 \\
58 \\
58 \\
56 \\
58 \\
51 \\
41 \\
36 \\
39 \\
50 \\
58 \\
56\end{array}$ & $\begin{array}{r}7 \\
57 \\
79 \\
111 \\
344 \\
236 \\
155 \\
100 \\
70 \\
72 \\
65 \\
61 \\
58 \\
58 \\
56 \\
58 \\
51 \\
41 \\
36 \\
39 \\
50 \\
55 \\
56\end{array}$ & \begin{tabular}{r|} 
Pि \\
57 \\
87 \\
105 \\
344 \\
182 \\
167 \\
90 \\
72 \\
72 \\
65 \\
60 \\
58 \\
58 \\
56 \\
58 \\
51 \\
40 \\
36 \\
39 \\
50 \\
55 \\
56
\end{tabular} & $\begin{array}{r}r \\
57 \\
89 \\
169 \\
357 \\
143 \\
148 \\
85 \\
72 \\
72 \\
65 \\
59 \\
58 \\
58 \\
56 \\
58 \\
49 \\
40 \\
36 \\
45 \\
50 \\
55 \\
56 \\
\end{array}$ & $\begin{array}{r}5 \\
57 \\
96 \\
187 \\
374 \\
124 \\
138 \\
75 \\
72 \\
72 \\
65 \\
59 \\
58 \\
58 \\
56 \\
58 \\
49 \\
40 \\
36 \\
45 \\
50 \\
56 \\
56\end{array}$ & $\begin{array}{r}\text { d' } \\
57 \\
97 \\
195 \\
403 \\
123 \\
133 \\
73 \\
68 \\
68 \\
65 \\
59 \\
58 \\
58 \\
56 \\
58 \\
49 \\
40 \\
36 \\
50 \\
50 \\
56 \\
56\end{array}$ & $\begin{array}{r}r \\
57 \\
93 \\
200 \\
446 \\
133 \\
133 \\
70 \\
68 \\
65 \\
65 \\
59 \\
58 \\
58 \\
58 \\
57 \\
48 \\
38 \\
36 \\
50 \\
50 \\
56 \\
57\end{array}$ & \begin{tabular}{r|} 
地 \\
57 \\
93 \\
272 \\
495 \\
149 \\
133 \\
67 \\
68 \\
63 \\
64 \\
58 \\
58 \\
58 \\
58 \\
56 \\
47 \\
36 \\
36 \\
50 \\
50 \\
56 \\
57
\end{tabular} & \begin{tabular}{r|}
$r$ \\
57 \\
90 \\
209 \\
541 \\
153 \\
128 \\
65 \\
67 \\
63 \\
64 \\
58 \\
58 \\
58 \\
58 \\
55 \\
47 \\
36 \\
38 \\
50 \\
50 \\
56 \\
57
\end{tabular} & \begin{tabular}{r|} 
f \\
57 \\
93 \\
308 \\
461 \\
148 \\
113 \\
68 \\
67 \\
63 \\
63 \\
58 \\
58 \\
58 \\
58 \\
55 \\
43 \\
36 \\
38 \\
50 \\
50 \\
56 \\
57 \\
\end{tabular} & $\begin{array}{r}7 \\
57 \\
93 \\
316 \\
426 \\
148 \\
108 \\
70 \\
67 \\
63 \\
62 \\
58 \\
58 \\
56 \\
58 \\
53 \\
43 \\
34 \\
40 \\
50 \\
50 \\
56 \\
57 \\
\end{array}$ & $\begin{array}{r}\text { f } \\
- \\
63 \\
93 \\
321 \\
356 \\
148 \\
98 \\
70 \\
67 \\
66 \\
62 \\
58 \\
58 \\
56 \\
58 \\
52 \\
\therefore \quad 43 \\
36 \\
40 \\
50 \\
57 \\
56 \\
57 \\
\end{array}$ & $\begin{array}{c}49 \\
48 \\
58 \\
89 \\
26 \\
406 \\
16 \\
138 \\
78 \\
69 \\
67 \\
64 \\
59 \\
58 \\
58 \\
57 \\
56 \\
48 \\
38 \\
37 \\
46 \\
51 \\
56 \\
57\end{array}$ \\
\hline $\begin{array}{l}\text { 丸 } \\
(\text { 一酎=付) }\end{array}$ & & $\begin{array}{cc}\text { E三 } & \text { 年 } \\
\text { 四 } & \text { 年 } \\
\text { 五 } & \text { 年 } \\
\text { 六 } & \text { 年 } \\
\text { 七 } & \text { 年 } \\
\text { 八 } & \text { 年 } \\
\text { 九 } & \text { 年 } \\
\text { 十 } & \text { 年 } \\
\text { 十二年 } \\
\text { 十三年 } \\
\text { 十三年 } \\
\text { 十四年 } \\
\text { 㕰 } \\
\text { 年 } \\
\text { 三 年 } \\
\text { 年 } \\
\text { 四 } \\
\text { 年 } \\
\text { 五 } \\
\text { 年 } \\
\text { 六 } & \text { 年 } \\
\text { 七 } & \text { 年 } \\
\text { 八 } & \text { 年 } \\
\text { 九 } & \text { 年 } \\
\text { 十 } & \text { 年 } \\
\text { 十一年 }\end{array}$ & $\begin{array}{r}89 \\
870 \\
205 \\
403 \\
245 \\
256 \\
135 \\
134 \\
126 \\
117 \\
120 \\
105 \\
91 \\
90 \\
111 \\
82 \\
57 \\
60 \\
100 \\
85 \\
105 \\
81 \\
\end{array}$ & $\begin{array}{r}- \\
96 \\
253 \\
228 \\
362 \\
213 \\
306 \\
124 \\
135 \\
160 \\
116 \\
113 \\
102 \\
89 \\
90 \\
107 \\
79 \\
58 \\
60 \\
103 \\
85 \\
103 \\
83 \\
\end{array}$ & $\begin{array}{r}- \\
89 \\
232 \\
249 \\
348 \\
192 \\
359 \\
142 \\
134 \\
145 \\
120 \\
112 \\
101 \\
87 \\
92 \\
105 \\
77 \\
59 \\
62 \\
111 \\
87 \\
101 \\
91\end{array}$ & $\begin{array}{r}- \\
144 \\
331 \\
310 \\
356 \\
207 \\
279 \\
133 \\
131 \\
130 \\
122 \\
111 \\
100 \\
86 \\
95 \\
105 \\
77 \\
60 \\
59 \\
107 \\
92 \\
100 \\
93 \\
\end{array}$ & $\begin{array}{r}142 \\
142 \\
221 \\
302 \\
378 \\
226 \\
217 \\
126 \\
126 \\
125 \\
119 \\
110 \\
95 \\
86 \\
101 \\
101 \\
76 \\
59 \\
58 \\
103 \\
93 \\
95 \\
91 \\
\end{array}$ & \begin{tabular}{r|}
116 \\
281 \\
302 \\
439 \\
242 \\
164 \\
128 \\
123 \\
120 \\
111 \\
107 \\
95 \\
87 \\
106 \\
98 \\
74 \\
58 \\
56 \\
93 \\
93 \\
88 \\
92 \\
\end{tabular} & $\begin{array}{r}118 \\
118 \\
278 \\
397 \\
492 \\
261 \\
174 \\
125 \\
122 \\
120 \\
109 \\
106 \\
94 \\
87 \\
105 \\
96 \\
72 \\
58 \\
54 \\
94 \\
95 \\
83 \\
93 \\
\end{array}$ & $\begin{array}{r}- \\
125 \\
181 \\
559 \\
476 \\
250 \\
193 \\
124 \\
121 \\
152 \\
110 \\
108 \\
93 \\
87 \\
115 \\
94 \\
68 \\
58 \\
53 \\
90 \\
103 \\
82 \\
92\end{array}$ & $\begin{array}{r}7 \\
129 \\
211 \\
484 \\
251 \\
234 \\
174 \\
132 \\
122 \\
156 \\
112 \\
113 \\
96 \\
89 \\
126 \\
91 \\
63 \\
58 \\
66 \\
88 \\
121 \\
85 \\
92\end{array}$ & $\begin{array}{r}136 \\
136 \\
203 \\
372 \\
426 \\
233 \\
159 \\
141 \\
127 \\
140 \\
112 \\
114 \\
96 \\
90 \\
133 \\
90 \\
62 \\
57 \\
79 \\
91 \\
119 \\
91 \\
96 \\
\end{array}$ & $\begin{array}{r}206 \\
191 \\
333 \\
314 \\
233 \\
259 \\
233 \\
127 \\
140 \\
113 \\
11 \\
95 \\
93 \\
118 \\
87 \\
60 \\
56 \\
91 \\
91 \\
108 \\
83 \\
106 \\
\end{array}$ & \begin{tabular}{r|}
346 \\
207 \\
325 \\
321 \\
233 \\
146 \\
126 \\
127 \\
123 \\
117 \\
709 \\
93 \\
91 \\
113 \\
83 \\
57 \\
58 \\
93 \\
88 \\
107 \\
81 \\
145 \\
\end{tabular} & $\begin{array}{c}75 \\
144 \\
211 \\
339 \\
390 \\
230 \\
215 \\
131 \\
127 \\
136 \\
115 \\
115 \\
97 \\
89 \\
107 \\
97 \\
71 \\
58 \\
66 \\
97 \\
99 \\
91 \\
96 \\
\end{array}$ \\
\hline 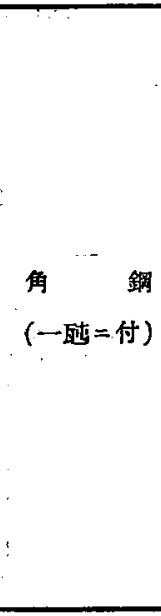 & $\begin{array}{l}\text { 大正 } \\
\text { 同 } \\
\text { 同 } \\
\text { 同 } \\
\text { 同 } \\
\text { 同 } \\
\text { 同 } \\
\text { 同 } \\
\text { 同 } \\
\text { 同 } \\
\text { 同 } \\
\text { 照 } \\
\text { 和 } \\
\text { 同 } \\
\text { 同 } \\
\text { 闰 } \\
\text { 同 } \\
\text { 同 } \\
\text { 同 } \\
\text { 闰 } \\
\text { 同 }\end{array}$ & 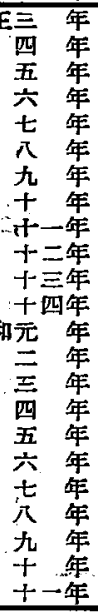 & $\begin{array}{r}7 \\
91 \\
279 \\
250 \\
372 \\
325 \\
277 \\
203 \\
145 \\
133 \\
141 \\
126 \\
116 \\
.96 \\
101 \\
119 \\
85 \\
62 \\
66 \\
107 \\
100 \\
113 \\
84\end{array}$ & $\begin{array}{r}- \\
96 \\
253 \\
275 \\
358 \\
293 \\
332 \\
195 \\
147 \\
165 \\
139 \\
123 \\
114 \\
95 \\
101 \\
116 \\
93 \\
59 \\
56 \\
167 \\
113 \\
100 \\
111 \\
84\end{array}$ & $\begin{array}{r}-1 \\
109 \\
239 \\
340 \\
380 \\
324 \\
337 \\
210 \\
148 \\
155 \\
143 \\
121 \\
115 \\
95 \\
101 \\
115 \\
91 \\
61 \\
67 \\
128 \\
100 \\
107 \\
92\end{array}$ & $\begin{array}{r}- \\
126 \\
237 \\
381 \\
399 \\
319 \\
300 \\
200 \\
154 \\
140 \\
155 \\
129 \\
114 \\
93 \\
101 \\
115 \\
91 \\
62 \\
66 \\
121 \\
108 \\
106 \\
94 \\
\end{array}$ & \begin{tabular}{|r|}
$\mid$ \\
131 \\
231 \\
365 \\
439 \\
271 \\
271 \\
178 \\
150 \\
135 \\
135 \\
122 \\
110 \\
94 \\
105 \\
112 \\
90 \\
62 \\
64 \\
615 \\
110 \\
100 \\
92 \\
110 \\
0
\end{tabular} & \begin{tabular}{r|}
- \\
120 \\
209 \\
346 \\
505 \\
271 \\
225 \\
172 \\
149 \\
135 \\
132 \\
123 \\
110 \\
96 \\
117 \\
111 \\
83 \\
62 \\
62 \\
102 \\
107 \\
92 \\
93 \\
\end{tabular} & $\begin{array}{r}-1 \\
129 \\
184 \\
408 \\
564 \\
593 \\
230 \\
165 \\
143 \\
135 \\
135 \\
121 \\
107 \\
98 \\
120 \\
108 \\
82 \\
61 \\
59 \\
99 \\
104 \\
87 \\
93\end{array}$ & $\begin{array}{r}- \\
133 \\
200 \\
500 \\
585 \\
279 \\
234 \\
152 \\
133 \\
143 \\
133 \\
123 \\
104 \\
100 \\
120 \\
106 \\
80 \\
61 \\
58 \\
98 \\
116 \\
87 \\
95\end{array}$ & $\begin{array}{r}- \\
137 \\
217 \\
452 \\
572 \\
261 \\
221 \\
141 \\
130 \\
188 \\
129 \\
123 \\
103 \\
102 \\
125 \\
105 \\
77 \\
60 \\
605 \\
108 \\
125 \\
90 \\
94\end{array}$ & $\begin{array}{r}- \\
145 \\
221 \\
372 \\
532 \\
252 \\
220 \\
144 \\
129 \\
188 \\
123 \\
122 \\
101 \\
103 \\
135 \\
103 \\
77 \\
59 \\
80 \\
111 \\
123 \\
94 \\
98 \\
\end{array}$ & $\begin{array}{r}206 \\
222 \\
338 \\
460 \\
252 \\
225 \\
141 \\
125 \\
167 \\
123 \\
123 \\
99 \\
103 \\
125 \\
100 \\
72 \\
59 \\
93 \\
109 \\
118 \\
89 \\
105 \\
\end{array}$ & $\begin{array}{r} \\
319 \\
250 \\
322 \\
346 \\
252 \\
212 \\
141 \\
127 \\
147 \\
122 \\
118 \\
96 \\
102 \\
123 \\
97 \\
65 \\
61 \\
95 \\
103 \\
114 \\
84 \\
155 \\
\end{array}$ & $\begin{array}{r}81 \\
145 \\
288 \\
369 \\
459 \\
283 \\
257 \\
170 \\
140 \\
153 \\
134 \\
123 \\
107 \\
98 \\
114 \\
109 \\
88 \\
61 \\
70 \\
109 \\
109 \\
97 \\
96 \\
\end{array}$ \\
\hline
\end{tabular}


材 市 價 調

\begin{tabular}{|c|c|c|c|c|c|c|c|c|c|c|c|c|c|c|}
\hline & 别 & 月 & 月 & $\equiv$ & 月 & $\boldsymbol{I}_{\mathbf{I}}$ & 六 & -七 & $\pi$. & 片 & + & 十一月 & 十二月 & 均 \\
\hline $\begin{array}{l}\text { 平 } \\
\text { (一銅 }\end{array}$ & 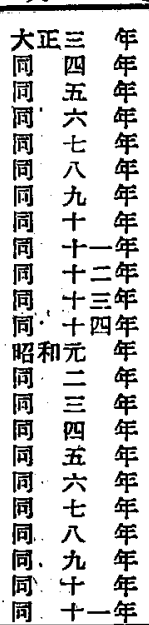 & \begin{tabular}{r|}
$\mathrm{H}$ \\
- \\
80 \\
261 \\
232 \\
378 \\
333 \\
269 \\
165 \\
146 \\
118 \\
142 \\
120 \\
114 \\
93 \\
98 \\
108 \\
89 \\
58 \\
63 \\
110 \\
91 \\
112 \\
82
\end{tabular} & $\begin{array}{r}r \\
86 \\
239 \\
236 \\
259 \\
319 \\
319 \\
151 \\
146 \\
140 \\
153 \\
119 \\
115 \\
93 \\
97 \\
107 \\
86 \\
59 \\
63 \\
118 \\
91 \\
109 \\
84\end{array}$ & $\begin{array}{r}\text { H } \\
101 \\
221 \\
247 \\
364 \\
261 \\
377 \\
160 \\
146 \\
140 \\
152 \\
119 \\
114 \\
83 \\
97 \\
109 \\
83 \\
59 \\
65 \\
127 \\
93 \\
107 \\
92\end{array}$ & $\begin{array}{r}1 \\
119 \\
221 \\
317 \\
412 \\
261 \\
311 \\
154 \\
140 \\
135 \\
152 \\
115 \\
113 \\
93 \\
97 \\
116 \\
82 \\
60 \\
64 \\
120 \\
94 \\
105 \\
94\end{array}$ & $\begin{array}{r}4 \\
123 \\
215 \\
306 \\
466 \\
271 \\
252 \\
148 \\
138 \\
130 \\
132 \\
113 \\
107 \\
95 \\
98 \\
117 \\
82 \\
60 \\
61 \\
106 \\
95 \\
99 \\
94\end{array}$ & $\begin{array}{r}114 \\
211 \\
311 \\
492 \\
266 \\
231 \\
138 \\
135 \\
157 \\
123 \\
112 \\
107 \\
97 \\
99 \\
110 \\
75 \\
60 \\
57 \\
95 \\
95 \\
90 \\
95\end{array}$ & $\begin{array}{r}7 \\
120 \\
176 \\
412 \\
527 \\
274 \\
232 \\
138 \\
127 \\
157 \\
123 \\
112 \\
102 \\
96 \\
99 \\
104 \\
74 \\
60 \\
56 \\
95 \\
97 \\
86 \\
95\end{array}$ & $\begin{array}{r}r \\
138 \\
141 \\
752 \\
524 \\
271 \\
237 \\
136 \\
125 \\
145 \\
120 \\
112 \\
99 \\
102 \\
99 \\
102 \\
73 \\
60 \\
56 \\
92 \\
105 \\
86 \\
95\end{array}$ & $\begin{array}{r}149 \\
224 \\
559 \\
532 \\
261 \\
225 \\
138 \\
122 \\
160 \\
117 \\
112 \\
99 \\
103 \\
105 \\
98 \\
72 \\
59 \\
63 \\
96 \\
117 \\
90 \\
96\end{array}$ & $\begin{array}{r}r \\
162 \\
226 \\
429 \\
519 \\
252 \\
210 \\
146 \\
119 \\
160 \\
117 \\
113 \\
97 \\
104 \\
102 \\
96 \\
70 \\
58 \\
80 \\
140 \\
119 \\
94 \\
99\end{array}$ & $\begin{array}{r}217 \\
219 \\
423 \\
452 \\
252 \\
207 \\
146 \\
117 \\
106 \\
117 \\
113 \\
96 \\
103 \\
109 \\
96 \\
66 \\
57 \\
93 \\
102 \\
113 \\
87 \\
108\end{array}$ & $\begin{array}{r}r \\
- \\
306 \\
233 \\
413 \\
340 \\
252 \\
182 \\
146 \\
115 \\
147 \\
118 \\
112 \\
95 \\
101 \\
106 \\
93 \\
60 \\
59 \\
95 \\
96 \\
111 \\
83 \\
156\end{array}$ & $\begin{array}{r}\text { म } \\
74 \\
143 \\
220 \\
379 \\
447 \\
272 \\
254 \\
147 \\
131 \\
146 \\
130 \\
115 \\
105 \\
98 \\
101 \\
105 \\
76 \\
59 \\
68 \\
105 \\
94 \\
96 \\
99\end{array}$ \\
\hline $\begin{array}{l}\text { 錭 } \\
(\text { 一造=付) }\end{array}$ & 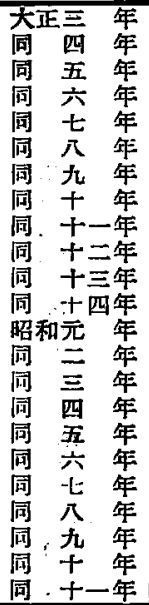 & $\begin{array}{r}- \\
90 \\
346 \\
319 \\
670 \\
351 \\
370 \\
155 \\
133 \\
164 \\
125 \\
147 \\
126 \\
102 \\
111 \\
113 \\
98 \\
51 \\
73 \\
172 \\
129 \\
134 \\
99\end{array}$ & $\begin{array}{r}- \\
93 \\
306 \\
371 \\
612 \\
298 \\
465 \\
144 \\
133 \\
182 \\
121 \\
147 \\
121 \\
109 \\
111 \\
113 \\
94 \\
64 \\
74 \\
155 \\
129 \\
130 \\
103\end{array}$ & $\begin{array}{r}107 \\
279 \\
384 \\
599 \\
293 \\
533 \\
154 \\
146 \\
125 \\
123 \\
144 \\
123 \\
111 \\
112 \\
117 \\
92 \\
71 \\
78 \\
175 \\
129 \\
125 \\
108\end{array}$ & $\begin{array}{r}112 \\
117 \\
420 \\
771 \\
298 \\
443 \\
146 \\
152 \\
125 \\
135 \\
141 \\
117 \\
112 \\
111 \\
126 \\
94 \\
68 \\
77 \\
143 \\
140 \\
125 \\
110\end{array}$ & $\begin{array}{r}106 \\
283 \\
450 \\
798 \\
298 \\
313 \\
140 \\
150 \\
125 \\
130 \\
136 \\
107 \\
118 \\
115 \\
131 \\
97 \\
68 \\
74 \\
121 \\
144 \\
116 \\
104\end{array}$ & $\begin{array}{r}104 \\
253 \\
743 \\
976 \\
290 \\
225 \\
136 \\
151 \\
120 \\
130 \\
129 \\
107 \\
126 \\
120 \\
135 \\
89 \\
66 \\
74 \\
124 \\
145 \\
107 \\
105\end{array}$ & $\begin{array}{r}109 \\
208 \\
700 \\
1,224 \\
306 \\
199 \\
130 \\
151 \\
120 \\
139 \\
128 \\
103 \\
117 \\
118 \\
138 \\
86 \\
65 \\
75 \\
131 \\
155 \\
99 \\
106\end{array}$ & $\begin{array}{r}-1 \\
120 \\
251 \\
1,019 \\
1,285 \\
314 \\
229 \\
124 \\
151 \\
125 \\
147 \\
135 \\
101 \\
113 \\
116 \\
122 \\
83 \\
65 \\
78 \\
127 \\
163 \\
96\end{array}$ & $\begin{array}{r}- \\
134 \\
273 \\
936 \\
1,117 \\
327 \\
210 \\
134 \\
154 \\
160 \\
140 \\
127 \\
101 \\
116 \\
116 \\
125 \\
77 \\
66 \\
89 \\
129 \\
172 \\
103 \\
111\end{array}$ & $\begin{array}{r}- \\
158 \\
279 \\
710 \\
939 \\
358 \\
189 \\
152 \\
154 \\
135 \\
136 \\
129 \\
106 \\
121 \\
115 \\
121 \\
77 \\
66 \\
124 \\
135 \\
157 \\
109 \\
113\end{array}$ & $\begin{array}{r}- \\
239 \\
284 \\
537 \\
665 \\
358 \\
188 \\
138 \\
154 \\
135 \\
142 \\
129 \\
110 \\
119 \\
113 \\
116 \\
67 \\
66 \\
146 \\
133 \\
139 \\
99 \\
126\end{array}$ & $\begin{array}{r}- \\
430 \\
306 \\
537 \\
354 \\
358 \\
172 \\
133 \\
159 \\
129 \\
147 \\
129 \\
105 \\
113 \\
111 \\
108 \\
51 \\
70 \\
153 \\
130 \\
133 \\
96 \\
197\end{array}$ & $\begin{array}{r}85 \\
150 \\
279 \\
569 \\
834 \\
320 \\
294 \\
140 \\
149 \\
137 \\
135 \\
134 \\
111 \\
115 \\
114 \\
122 \\
84 \\
66 \\
93 \\
140 \\
144 \\
112 \\
116 \\
\end{array}$ \\
\hline
\end{tabular}

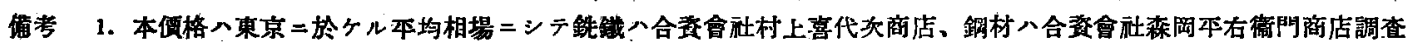
$=$ 依市

2. 丸銅了昭和五年五月以前八四分。昭和五年六月以降ハ16粍以上ベース

3. 角銅

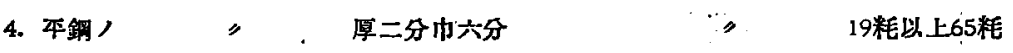

5. 銅板， 巾四尺长八尺厚一分＂＂４８８4.5粍以上ペース 
內地製鐵業者鐵

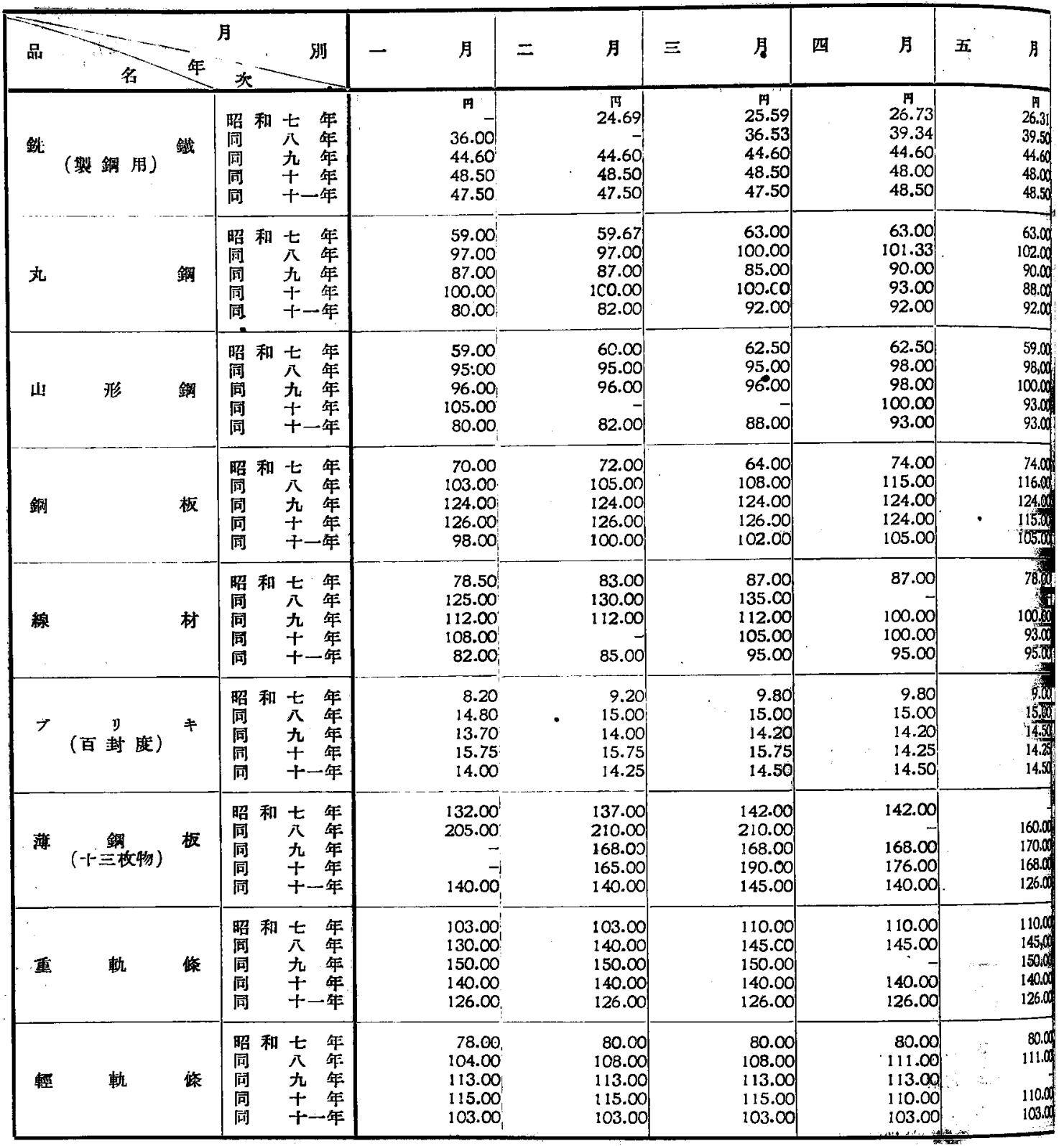

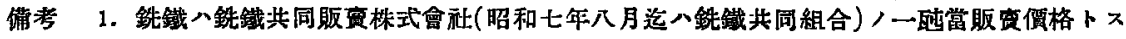

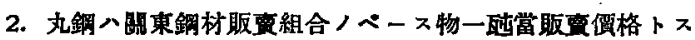

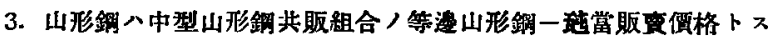

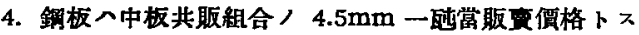

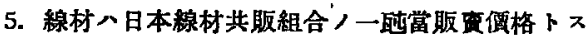

6. 錻力板ハ八橎整鐵所ノ先物值段ニシテ各一函當トス

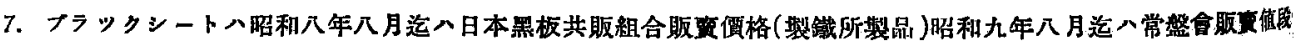

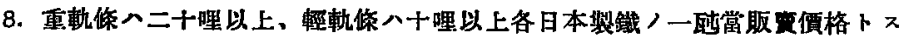




\section{鋮材眅賣價格調}

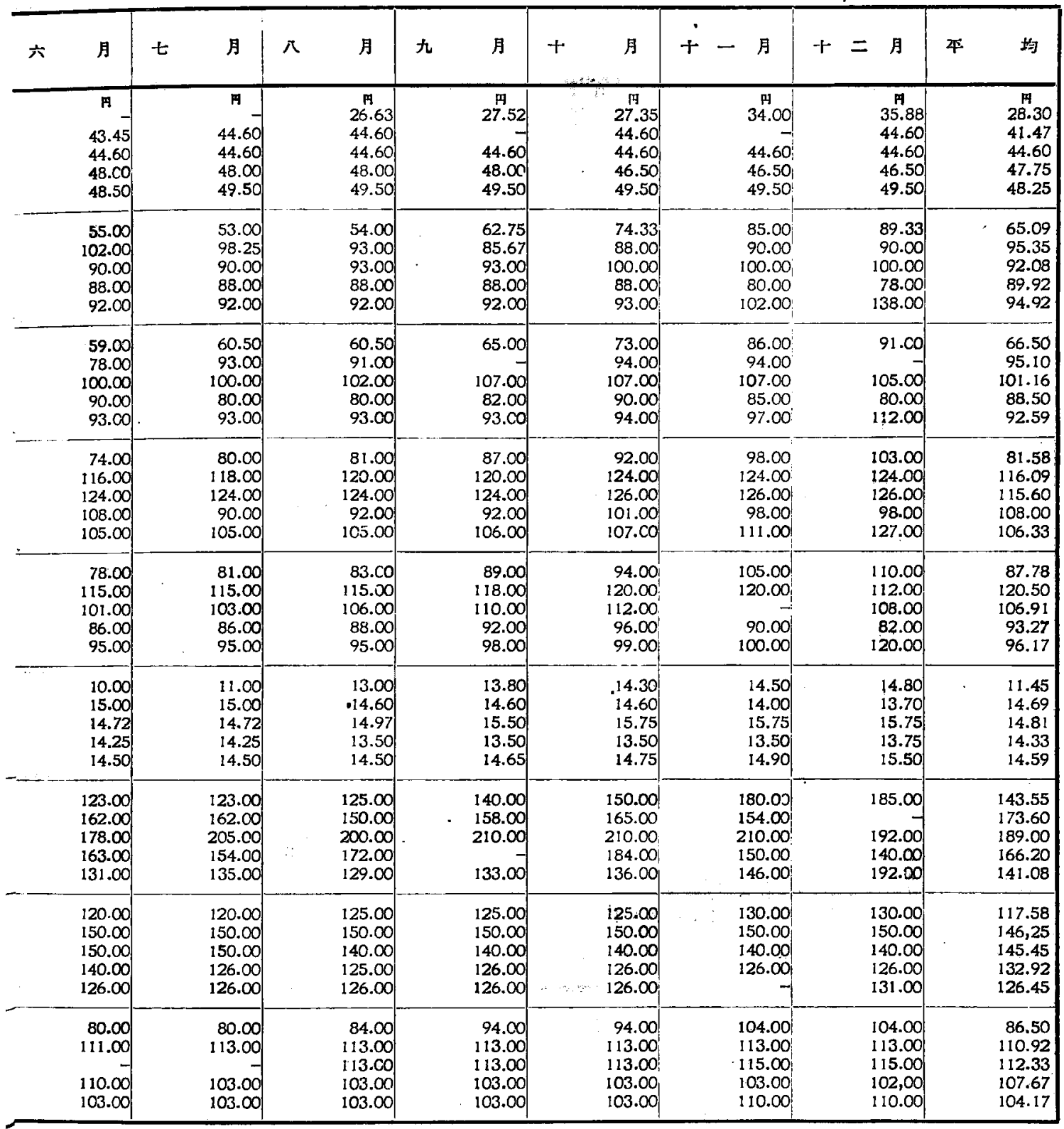




\section{內 地主 要鋼 材}

\begin{tabular}{|c|c|c|c|c|c|c|c|c|c|c|c|}
\hline 品 $>$ 行 & 别 & - & 月 & $=$ & 月 & $\equiv$ & 月 & 四 & 月 & 五 & 月 \\
\hline 棒 $(\hat{*}-x)^{\text {銅 }}$ & 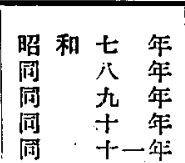 & 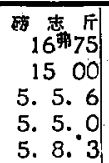 & \begin{tabular}{c|}
17 \\
46.56 \\
72.32 \\
89.63 \\
90.00 \\
92.79
\end{tabular} & 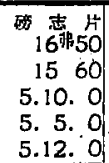 & \begin{tabular}{c|}
14 \\
48.26 \\
75.00 \\
93.45 \\
96.00 \\
96.00
\end{tabular} & 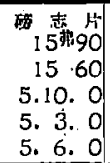 & \begin{tabular}{|c|}
7 \\
49.46 \\
73.87 \\
93.45 \\
88.29 \\
90.86 \\
\end{tabular} & 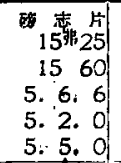 & \begin{tabular}{|c|}
19 \\
46.39 \\
71.69 \\
90.88 \\
87.43 \\
90.00 \\
\end{tabular} & 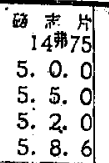 & $\begin{array}{l}7 \\
46,11 \\
83.28 \\
89.64 \\
87.4 \\
98.90\end{array}$ \\
\hline 小形山形 銅 & 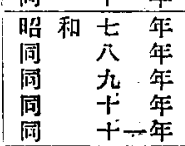 & $\begin{array}{rl}16 \% & 50 \\
17 & 40 \\
5.12 .0 \\
5.19 .0 \\
6.3 .3\end{array}$ & \begin{tabular}{r|}
45.87 \\
85.12 \\
95.15 \\
102.00 \\
105.64
\end{tabular} & $\begin{array}{r}16.20 \\
16.00 \\
5.19 .9 \\
5.16 .0 \\
6.8 .3\end{array}$ & \begin{tabular}{r|}
47.38 \\
76.93 \\
101.73 \\
99.43 \\
109.93
\end{tabular} & $\begin{array}{r}15 \text { 非90 } \\
4.16,0 \\
5.19 .9 \\
6.2 .1 .0\end{array}$ & $\begin{array}{r}49.46 \\
72.10 \\
101.73 \\
105.29\end{array}$ & 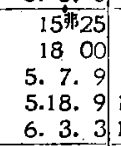 & \begin{tabular}{|}
46.39 \\
82.72 \\
91.95 \\
101.79 \\
105.64 \\
\end{tabular} & \begin{tabular}{r|r|}
14. & \\
5.11 .0 & \\
5.14 .6 \\
5.17 .9 \\
5.18 .3
\end{tabular} & 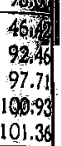 \\
\hline 銅 & $\begin{array}{lll}\text { 昭和七 } & \text { 年 } \\
\text { 同 } & \text { 年 } \\
\text { 同 九 } \\
\text { 间 } \\
\text { 年 } \\
\text { 同 } \text { 十一年 }\end{array}$ & $\begin{array}{r}20 弓 \\
5.7 .6 \\
6.10 .9 \\
6.13 .6 \\
6.19 .0 \\
\end{array}$ & \begin{tabular}{r|}
55.43 \\
92.08 \\
111.08 \\
114.43 \\
119.14 \\
\end{tabular} & $\begin{array}{r}19 . \\
18.70 \\
6.18 .0 \\
6.11 .0 \\
6.19 .0 \\
\end{array}$ & $\begin{array}{r}56.30 \\
89.91 \\
117.24 \\
112.29 \\
119.14 \\
\end{array}$ & $\begin{array}{r}18 \\
5.17 .0 \\
7.0 .0 \\
6.14 .0 \\
\end{array}$ & $\begin{array}{r}57.86 \\
96.22 \\
118.94 \\
\end{array}$ & \begin{tabular}{r|r|}
18 & 90 \\
22 & 0 \\
6.17. & 6 \\
6.11 .0 & 0 \\
6.14. & 0 \\
\end{tabular} & \begin{tabular}{|l|}
57.50 \\
101.10 \\
117.33 \\
112.29 \\
114.86 \\
\end{tabular} & $\begin{array}{l}17^{569} \\
6.10 .0 \\
6.14 .6 \\
6.7 .0 \\
6.14 .0\end{array}$ & 59 \\
\hline 線 $(1-\nabla x)^{\text {材 }}$ & $\begin{array}{lll}\text { 昭 } & \text { 和 } & \text { 年 } \\
\text { 同 } & \text { 年 } \\
\text { 同 } & \text { 年 } \\
\text { 同 } & \text { 十 } \\
\text { 年同 } & + \text { 年 }\end{array}$ & $\begin{array}{rl}25 & \\
24 & 00 \\
6.0 .0 & 0 \\
5.10 .0 \\
5.5 .0\end{array}$ & \begin{tabular}{|r|}
70.88 \\
115.72 \\
101.95 \\
94.29 \\
90.00
\end{tabular} & 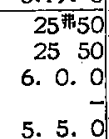 & $\begin{array}{r}74.58 \\
122.60 \\
101.95 \\
90.00\end{array}$ & $\begin{aligned} & 25 \text { 弗50 } \\
& 7.10 .0 \\
& 6.0 .0 \\
& 5.8 .0 \\
& 5.0 .0\end{aligned}$ & \begin{tabular}{|r|}
79.33 \\
123.36 \\
101.95 \\
92.57 \\
85.71
\end{tabular} & 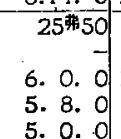 & $\mid \begin{array}{r}-77.57 \\
102.40 \\
92.57 \\
85.71\end{array}$ & $\begin{array}{r}25,50 \\
7.10 .0 \\
5.15 .9 \\
5.7 .0 \\
4.15 .0\end{array}$ & $\begin{array}{r}124.94 \\
98.13 \\
91.71 \\
81.43\end{array}$ \\
\hline 重（レー俥）ミ $)^{\text {條 }}$ & 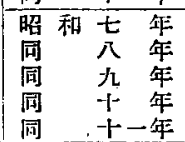 & $\begin{array}{r}7.4 .0 \\
30 \text {. } 38 \\
8.11 . ?\end{array}$ & \begin{tabular}{|l|}
68.90 \\
146.48 \\
145.12
\end{tabular} & $\begin{array}{r}7.4 .0 \\
29.40 \\
8.10 .0\end{array}$ & \begin{tabular}{|l|}
72.95 \\
141.35 \\
146.12
\end{tabular} & $\begin{array}{r}7.4 .0 \\
255^{\circ} 75 \\
8.11 .0\end{array}$ & \begin{tabular}{r|}
81.40 \\
121.93 \\
146.12
\end{tabular} & $8.11 . \overline{0}$ & $\begin{array}{r}77.45 \\
146.77\end{array}$ & $8.15: 0$ & 77.76 \\
\hline 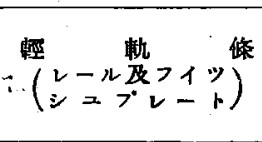 & 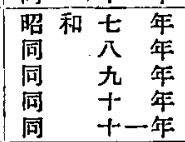 & $\begin{array}{r}22 \\
1800 \\
5.13 .8\end{array}$ & $\begin{array}{l}61.15 \\
85.75 \\
96.57\end{array}$ & $\begin{array}{r}18 \text { 弗50 } \\
5.10 . \overline{0}\end{array}$ & \begin{tabular}{l|}
54.11 \\
93.45
\end{tabular} & $\begin{array}{r}18 \text { " } 50 \\
5.10 .0\end{array}$ & \begin{tabular}{r|}
57.55 \\
93.45
\end{tabular} & 5.13. $\overline{6}$ & 92.72 & & \\
\hline 海 $(+$ 铜枚物) & 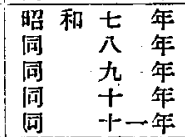 & $\begin{array}{l}10.13 .6 \\
12.5 .0 \\
12.12 .6\end{array}$ & $\mid \begin{array}{l}102.15 \\
199.00 \\
214.51\end{array}$ & $\begin{array}{l}10.10 .0 \\
12.2 .6 \\
12.12 .6\end{array}$ & \begin{tabular}{|l|}
106.38 \\
199.95 \\
214.51
\end{tabular} & $\begin{array}{l}10.15 .0 \\
12.5 .0\end{array}$ & \begin{tabular}{|l|}
21.54 \\
201.41
\end{tabular} & $\begin{array}{l}\text { 11.5. } \\
\text { 12. 5. } 0\end{array}$ & $\begin{array}{l}129.09 \\
200.14\end{array}$ & $\begin{array}{l}10.17 .0 \\
11.17 .6 \\
12.0 .0\end{array}$ & $\begin{array}{l}125.00 \\
197.81 \\
204,80\end{array}$ \\
\hline${ }^{7}$ (百封度) & $\begin{array}{lll}\text { 照和 } & \text { 年 } \\
\text { 同 } & \text { 年 } \\
\text { 同 } & \text { 年 } \\
\text { 同 } & \text { 十 } \\
\text { 年 } \\
\text { 同一年 }\end{array}$ & \begin{tabular}{r|}
0.16 .0 \\
0.17 .8 \\
4 tiod \\
3.17 \\
4.72
\end{tabular} & $\begin{array}{r}7.66 \\
14.34 \\
13.46 \\
11.16 \\
16.33\end{array}$ & $\begin{array}{r}0 . \overline{16.0} \\
0.17 .6 \\
4{ }^{3} 10 \\
476 \\
466\end{array}$ & \begin{tabular}{|r|}
8.11 \\
14.43 \\
13.87 \\
16.77 \\
16.06
\end{tabular} & $\begin{array}{r}0.17 .9 \\
0.17 .6 \\
4 \mu_{17} 17 \\
470 \\
467\end{array}$ & $\begin{array}{l}10.03 \\
14.39 \\
13.94 \\
16.85 \\
16.13\end{array}$ & 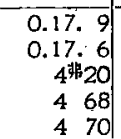 & \begin{tabular}{|l|}
10.18 \\
14.30 \\
13.89 \\
16.55 \\
16.29
\end{tabular} & $\begin{array}{r}0.17 .1 \\
0.17 .6 \\
4 \quad 6 \\
4.67 \\
4 \quad 60 \\
4 \quad 80\end{array}$ & $\begin{array}{l}9.84 \\
14.58 \\
14.46 \\
16.38 \\
16.55 \\
\end{array}$ \\
\hline
\end{tabular}

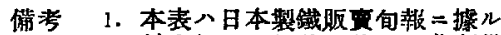

2. 䟼力板八一箱期，他八一英濑當ナり

3. 䞒板八眧和八年汽へ 3.2 耗、昭和九年以降八 4.5 耗ナリ

4. 海銅板八英國物ナり

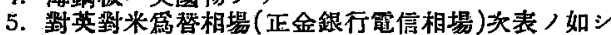

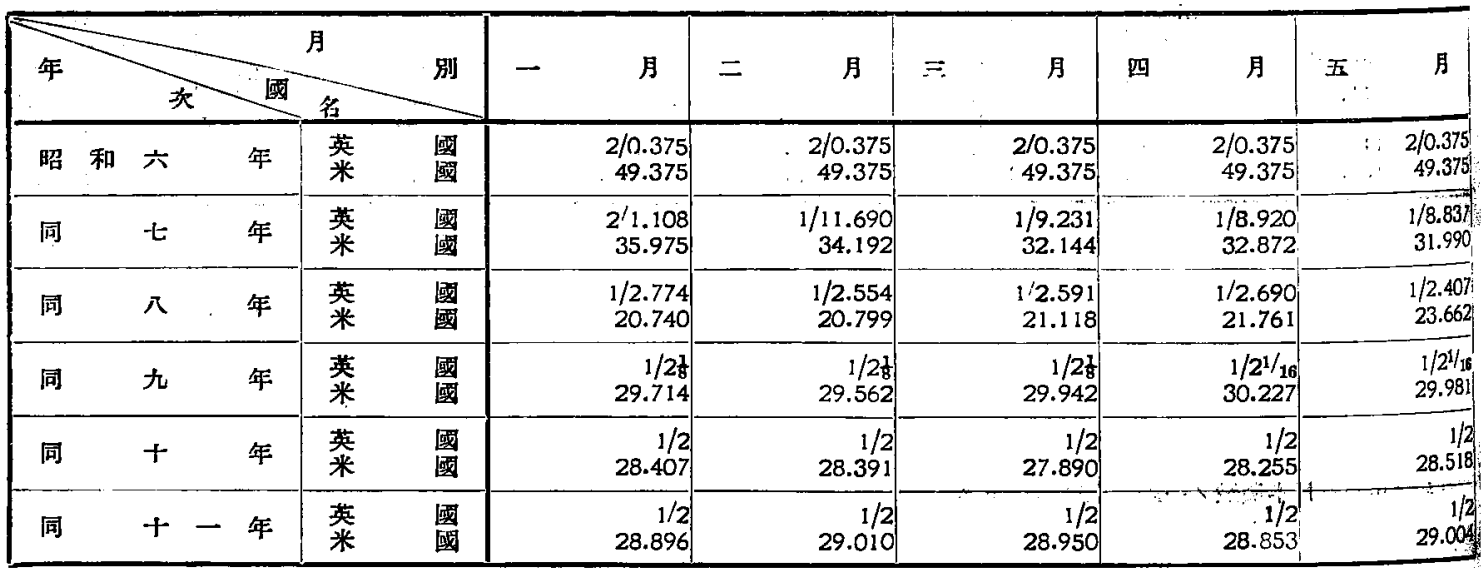




\section{輸入沖着價格調}

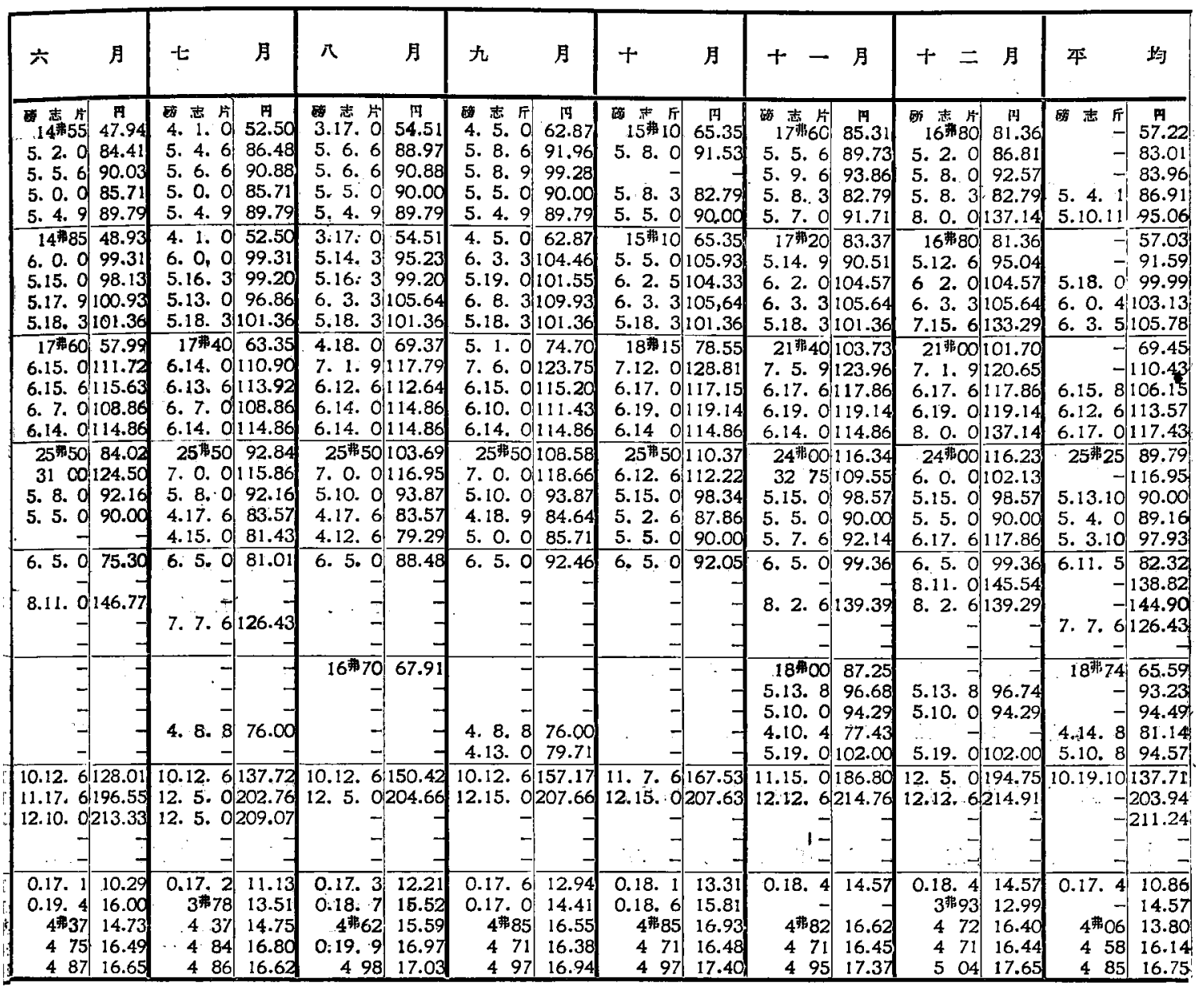

\begin{tabular}{|c|c|c|c|c|c|c|c|c|c|c|c|c|c|}
\hline 六 & 月 & $\because t$ & $\therefore$ 月 & 公 & 月 & 九 & 月 & + & 月 & + 一 & + 二 月 & 平 & 均 \\
\hline & $\begin{array}{r}2 / 0.337 \\
49.375\end{array}$ & & $\begin{array}{r}2 / 0.349 \\
49.375\end{array}$ & & $\begin{array}{r}2 / 0.375 \\
49.375\end{array}$ & & $\begin{array}{r}2 / 1.672 \\
49.375\end{array}$ & & $\begin{array}{r}2 / 5.651 \\
49.375\end{array}$ & $\begin{array}{r}2 / 7.282 \\
49.375\end{array}$ & $\begin{array}{r}2 / 11.454 \\
49.375\end{array}$ & & $\begin{array}{r}2 / 2.416 \\
49.375\end{array}$ \\
\hline & $\begin{array}{r}1 / 7.918 \\
30.351\end{array}$ & & $\begin{array}{r}1 / 6.521 \\
27.466\end{array}$ & & $\begin{array}{r}1 / 4.653 \\
24.592\end{array}$ & & $\begin{array}{r}1 / 4.223 \\
23.484\end{array}$ & & $\begin{array}{r}1 / 4.295 \\
23.105\end{array}$ & $\begin{array}{r}1 / 3.093 \\
20.630\end{array}$ & $\begin{array}{r}1 / 3.097 \\
20.648\end{array}$ & & $\begin{array}{r}1 / 7.157 \\
28.120\end{array}$ \\
\hline & $\begin{array}{r}1 / 2 \frac{1}{2} \\
24.990\end{array}$ & & $\begin{array}{r}1 / 2 \frac{1}{2} \\
27.986\end{array}$ & & $\begin{array}{r}1 / 2.365 \\
26.796\end{array}$ & & $\begin{array}{r}1 / 2.158 \\
27.165\end{array}$ & & $\begin{array}{r}1 / 2.160 \\
27.560\end{array}$ & $\begin{array}{r}1 / 2.109 \\
29.895\end{array}$ & $\begin{array}{r}1 / 2.099 \\
30.250\end{array}$ & & $\begin{array}{r}1 / 2.409 \\
25.227\end{array}$ \\
\hline & $\begin{array}{r}1 / 2^{1 / 61} \\
29.655\end{array}$ & & $\begin{array}{r}1 / 2,6^{1} \\
29 . \frac{5}{8}\end{array}$ & & $\begin{array}{r}1 / 2^{1 / 16} \\
29.662\end{array}$ & & $\begin{array}{r}1 / 2^{1 / 16} \\
29.302\end{array}$ & & $\begin{array}{r}1 / 2.033 \\
28.682\end{array}$ & $\begin{array}{r}1 / 2 \\
29.010\end{array}$ & $\begin{array}{r}1 / 2 \\
28.776\end{array}$ & & $\begin{array}{l}1 / 2.065 \\
29.51\end{array}$ \\
\hline & $\begin{array}{r}1 / 2 \\
28.815\end{array}$ & & $\begin{array}{r}1 / 2 \\
28.967\end{array}$ & & $\begin{array}{r}1 / 2 \\
29.050\end{array}$ & & $\begin{array}{r}1 / 2 \\
28.760\end{array}$ & & $\begin{array}{r}1 / 2 \\
28.562\end{array}$ & $\begin{array}{r}1 / 2 \\
28.603\end{array}$ & $\begin{array}{r}1 / 2 \\
28.625\end{array}$ & & $\begin{array}{r}1 / 2 \\
28.570\end{array}$ \\
\hline & $\begin{array}{r}1 / 2 \\
29.254\end{array}$ & & $\begin{array}{r}1 / 2 \\
29.250\end{array}$ & & $\begin{array}{r}1 / 2 \\
29.250\end{array}$ & & $\begin{array}{r}1 / 2 \\
29.340\end{array}$ & & $\begin{array}{r}1 / 2 \\
28.557\end{array}$ & $\begin{array}{r}1 / 2 \\
28.500\end{array}$ & $\begin{array}{r}1 / 2 \\
28.552 \\
\end{array}$ & & $\begin{array}{r}1 / 2 \\
28.951\end{array}$ \\
\hline
\end{tabular}


(其

\begin{tabular}{|c|c|c|c|}
\hline & 所 & 在 & 地 \\
\hline & 部 & I & 場 \\
\hline 日本製践株式會社 & 果京市眐町區九，内二丁目二十番地一 & 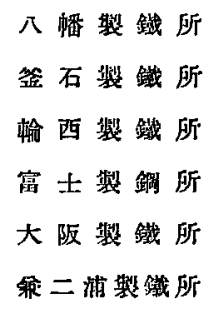 & 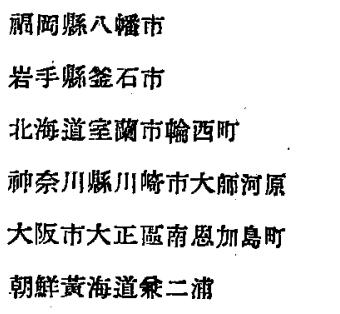 \\
\hline 株侙會社 日本製銅所 & 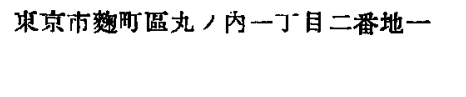 & $\begin{array}{l}\text { 室 } \text { 工場 } \\
\text { 磨 島 } \text { 場 }\end{array}$ & 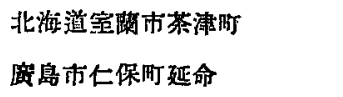 \\
\hline 取京鋼材株式會社 & 東京市域東區大島咑六丁目 & 展的褧鍼工場 & 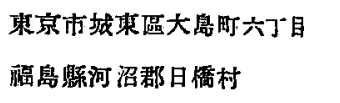 \\
\hline 日本曹達株式合 & 果京市数町區九ノ內二丁目 & 會 津 工 場 & 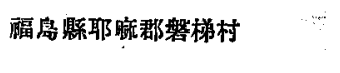 \\
\hline 日本鋯銅株式會社 & 東京市城東區大易町七丁目 & & 東京市城東區大島町七丁`目 \\
\hline 株式會社 大島製銅所 & 東京市城東區大島町四丁目 & & 東京市城東區大島町四丁目 \\
\hline 株式侖社 吾䪞製鋼 所 & 東京市向島區吾靇町果四丁目 & $\begin{array}{l}\text { 千位驖板製造所 } \\
\text { 砂 町 工 堨 }\end{array}$ & $\begin{array}{l}\text { 東京市向島區吾䇕町東四丁目 } \\
\text { 東京市足立區千住鱰町 } \\
\text { 東京市城東區南砂町六丁目 }\end{array}$ \\
\hline 株式會滆 日 立 製 作 所 & 東京市数町區丸／內二丁゙目 & $\begin{array}{l}\text { 深川工場 } \\
\text { 木津川工場 } \\
\text { F畑工場 } \\
\text { 安 來 工場 } \\
\text { 同宇部分工場 }\end{array}$ & 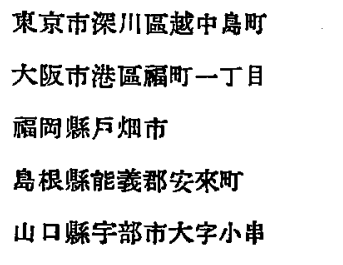 \\
\hline 日本特殊銅株式合社 & 東京市大森區大森一つ”目 & & 果京市大森區大森一丁目 \\
\hline 日本鍓管株式會社 & 神奈川縣川橴市僦田 & $\begin{array}{l}\text { 川 崎 } \text { 工 場 } \\
\text { 電 氣製 鐵 所 } \\
\text { 新渴電氣製鐵所 }\end{array}$ & 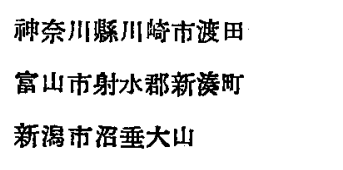 \\
\hline 鹤見製鐵造船株式會衤 & 数町藏丸/內一丁目 & 鹳 見工埸 & 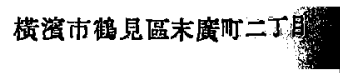 \\
\hline 日本鐠造株式合社 & 棃町區丸／肉一丁目 & 鹤 見工場 & 横演市鹤見區末廣町二丁目 \\
\hline
\end{tabular}




\section{損㿽、配當及铂業者數調}

$\rightarrow)$

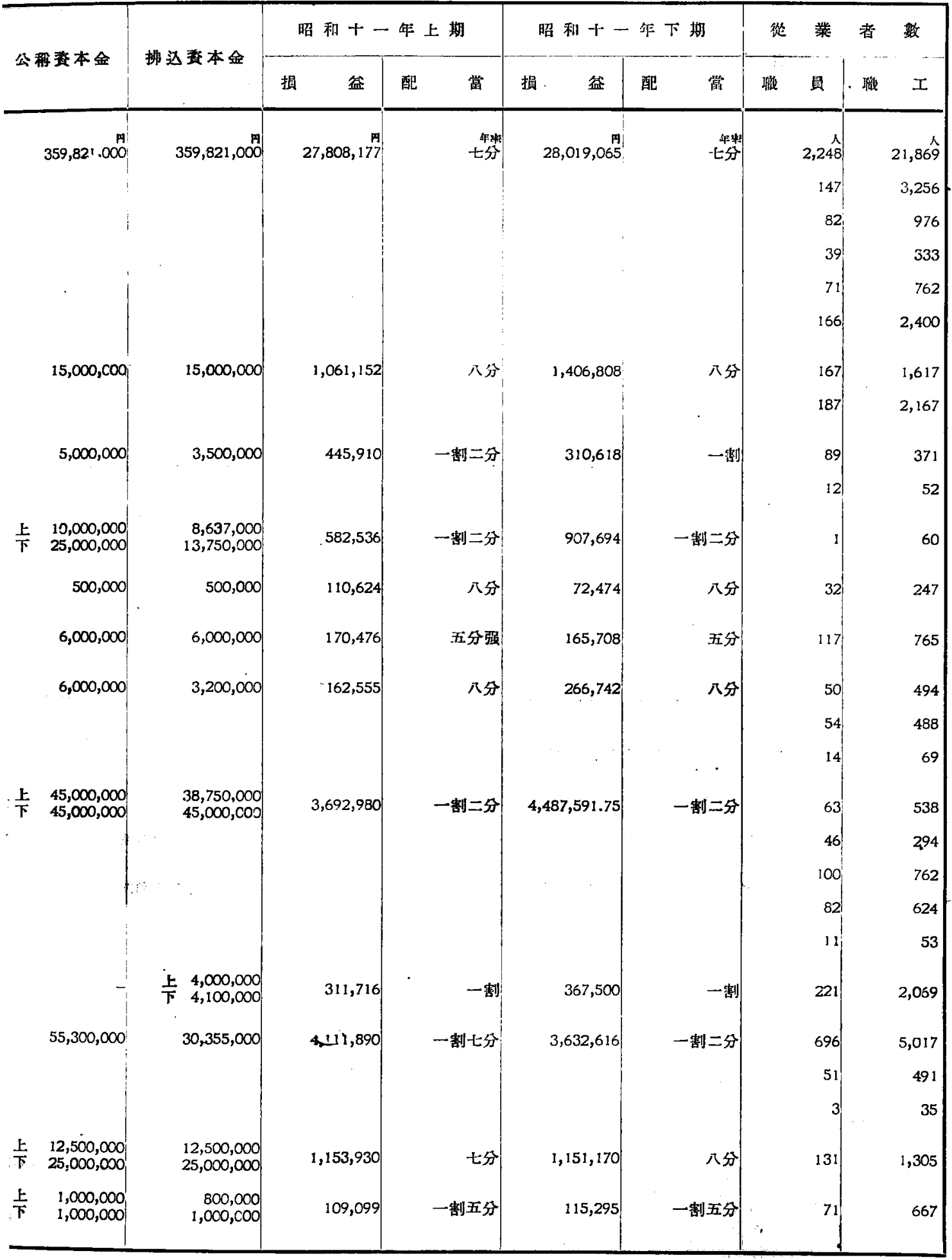


（其

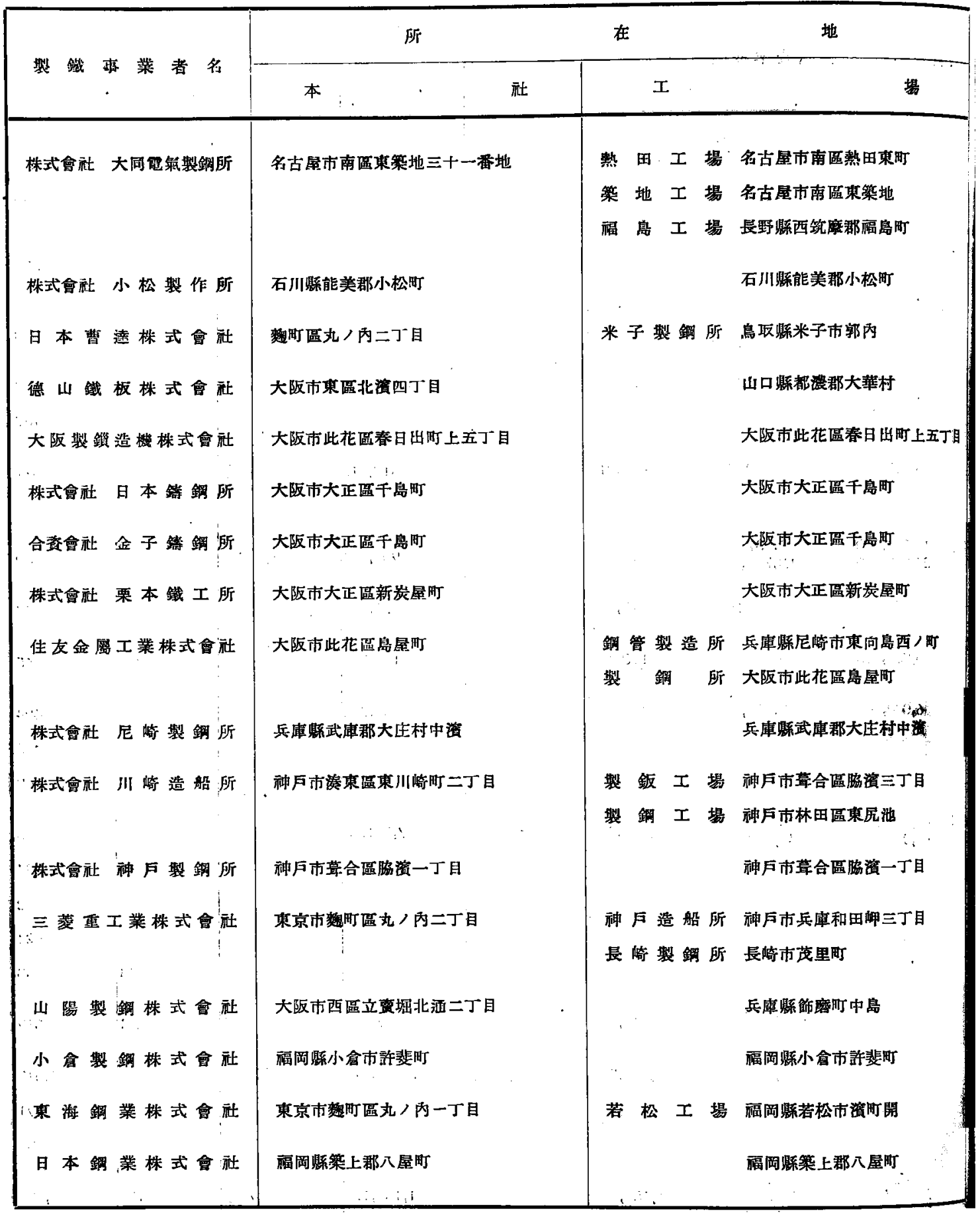




\section{損盆配當及從業者數調}

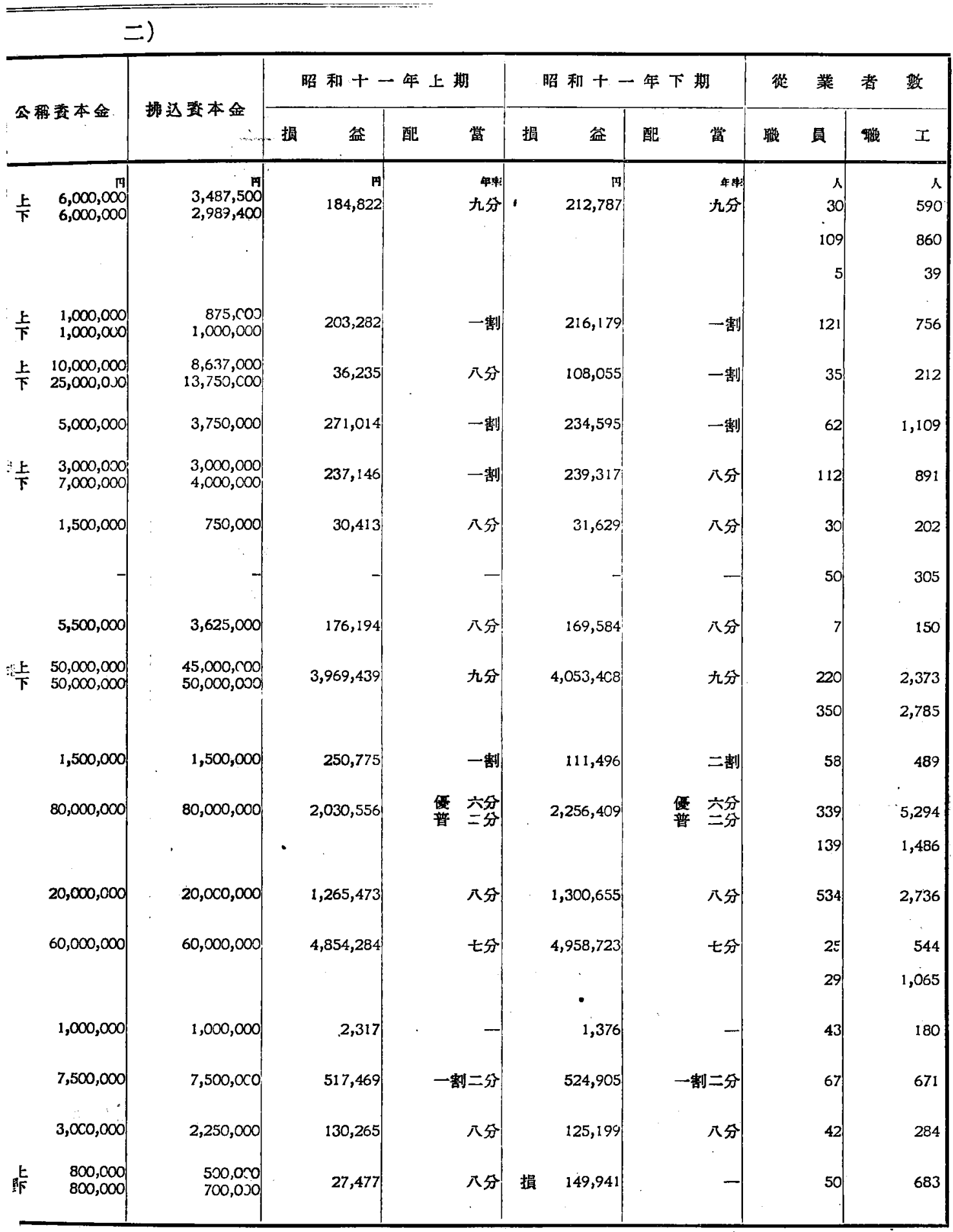


世界二於ヶル

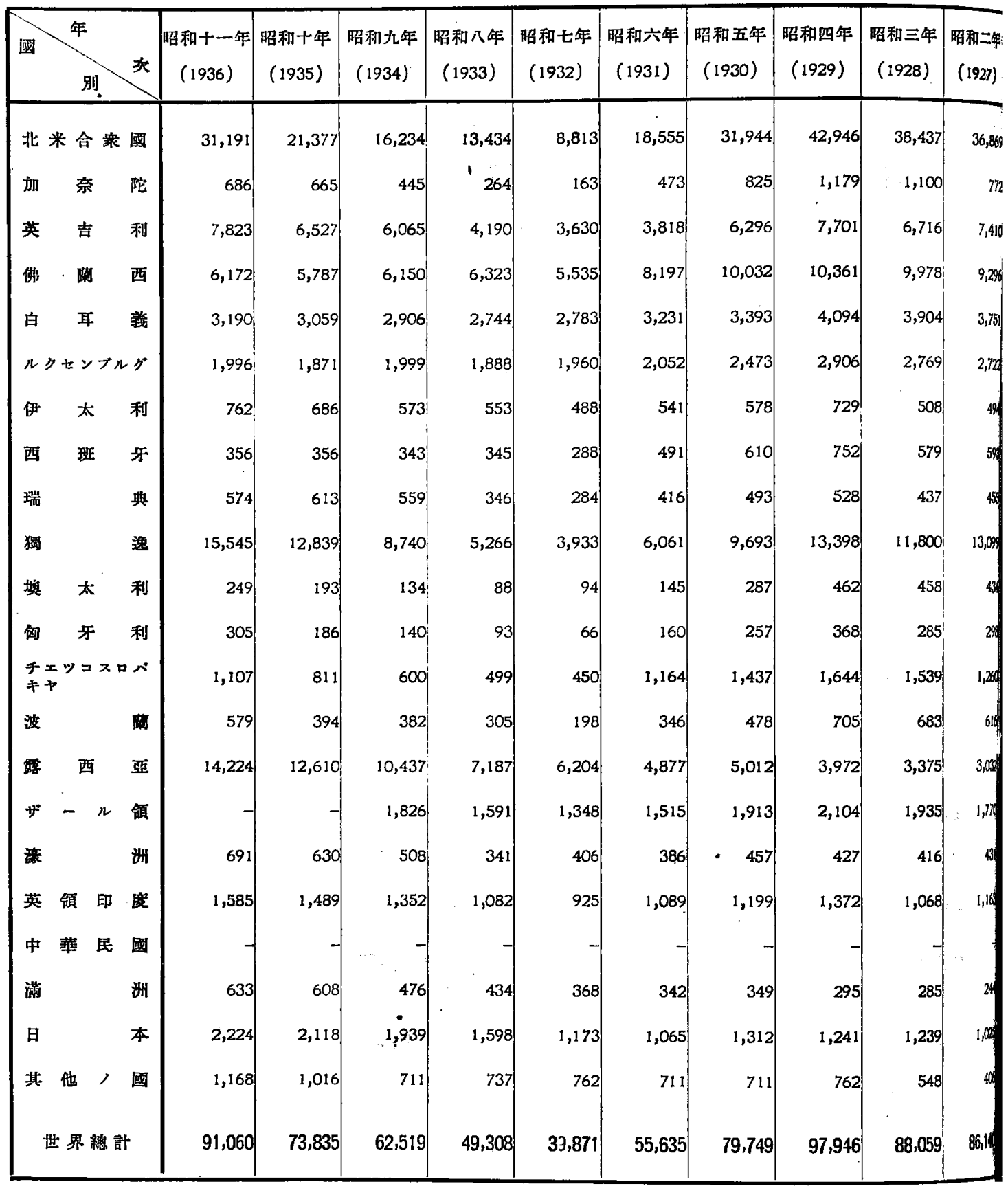

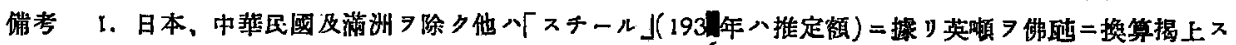

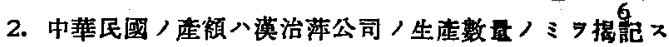

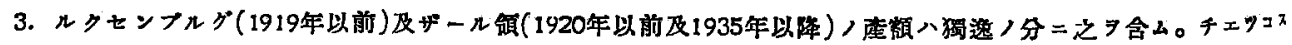




\section{銑 鐵 產 額 調}

（單 位 千 酶）

\begin{tabular}{|c|c|c|c|c|c|c|c|c|c|c|}
\hline $\begin{array}{l}\text { (利元年 } \\
\text { (1926) }\end{array}$ & $\begin{array}{c}\text { 大正十四年 } \\
(1925)\end{array}$ & $\begin{array}{c}\text { 大正十三年 } \\
(1924)\end{array}$ & $\begin{array}{c}\text { 大正十二年 } \\
\text { (1923) }\end{array}$ & $\begin{array}{c}\text { 大正十一年 } \\
(1922)\end{array}$ & $\begin{array}{c}\text { 大正十年 } \\
(1921)\end{array}$ & $\begin{array}{c}\text { 大正九年 } \\
(1920)\end{array}$ & $\begin{array}{c}\text { 大正八年 } \\
\text { (1919) }\end{array}$ & $\begin{array}{c}\text { 大正比年 } \\
\text { (1918) }\end{array}$ & $\begin{array}{c}\text { 大正六年 } \\
\text { (1917) }\end{array}$ & $\begin{array}{c}\text { 大正二年 } \\
\text { (1913) }\end{array}$ \\
\hline 39,727 & 36,952 & 31,574 & 40,666 & 27,281 & 16,770 & 36,983 & 31,068 & 39,052 & 38,776 & 31,143 \\
\hline 788 & 606 & 623 & 924 & 410 & 627 & 1,015 & 876 & 1,125 & 1,103 & 1,031 \\
\hline 2,469 & 6,336 & 7,436 & 7,559 & 4,980 & 2,658 & 8,164 & 7,516 & 9,231 & 9,471 & 10,424 \\
\hline 9,429 & 8,492 & $7,69.1$ & 5,432 & 5,229 & 3,361 & 3,434 & 2,412 & 1,306 & 1,734 & 5,208 \\
\hline 3,399 & 2,541 & 2,807 & 2,189 & 1,603 & 876 & 1,117 & $25 \mathrm{I}$ & 1 & 8 & 2,467 \\
\hline 2,512 & 2,362 & 2,174 & 1,406 & 1,676 & 970 & 693 & 618 & - & - & - \\
\hline 513 & 482 & 304 & 247 & 92 & 76 & 109 & 255 & 333 & 505 & 427 \\
\hline 457 & 468 & 405 & 400 & 178 & 178 & 252 & 295 & 386 & 853 & 425 \\
\hline 456 & 432 & 506 & 277 & 259 & 309 & 485 & 509 & 778 & 356 & 742 \\
\hline 9,641 & 10,174 & 7,812 & 4,935 & 9,394 & 7,843 & 7,042 & 6,282 & 9,206 & 11,619 & 19,304 \\
\hline 388 & 380 & 266 & 344 & 322 & 214 & 98 & 62 & - & 2,032 & 2,380 \\
\hline 188 & 93 & 300 & 300 & 250 & 51 & 30 & - & - & - & $\therefore-$ \\
\hline 1,086 & 1,165 & 986 & 762 & 344 & 541 & 710 & 627 & - & - & - \\
\hline 327 & 315 & 331 & 520 & 465 & 650 & 102 & - & - & - & - \\
\hline 2,426 & 1,545 & 752 & 528 & 127 & 117 & 15 & - & - & 1,524 & 4,558 \\
\hline 1,625 & 1,453 & 1,347 & 929 & 1,158 & 965 & 940 & - & - & - & - \\
\hline 449 & 446 & 423 & 305 & 254 & 323 & 261 & 240 & 180 & 149 & 48 \\
\hline 914 & 902 & 891 & 545 & 356 & 377 & 317 & 325 & 269 & 256 & - \\
\hline- & 53 & 27 & 73 & 149 & 124 & 125 & 166 & 139 & 150 & 98 \\
\hline 198. & 137 & 134 & 98 & 60 & 94 & 116 & 106 & 46 & 39 & - \\
\hline 925 & 784 & 686 & 700 & 634 & 556 & 605 & 674 & 625 & 451 & 240 \\
\hline 35.1 & 254 & 203 & 203 & 102 & 151 & 184 & 102 & 70 & 102 & 203 \\
\hline 78,270 & 76,372 & 67,679 & 69,342 & 55,323 & 37,831 & 62,797 & 52,384 & 62,747 & 69,128 & 78,698 \\
\hline
\end{tabular}




\section{世界二於ヶ}

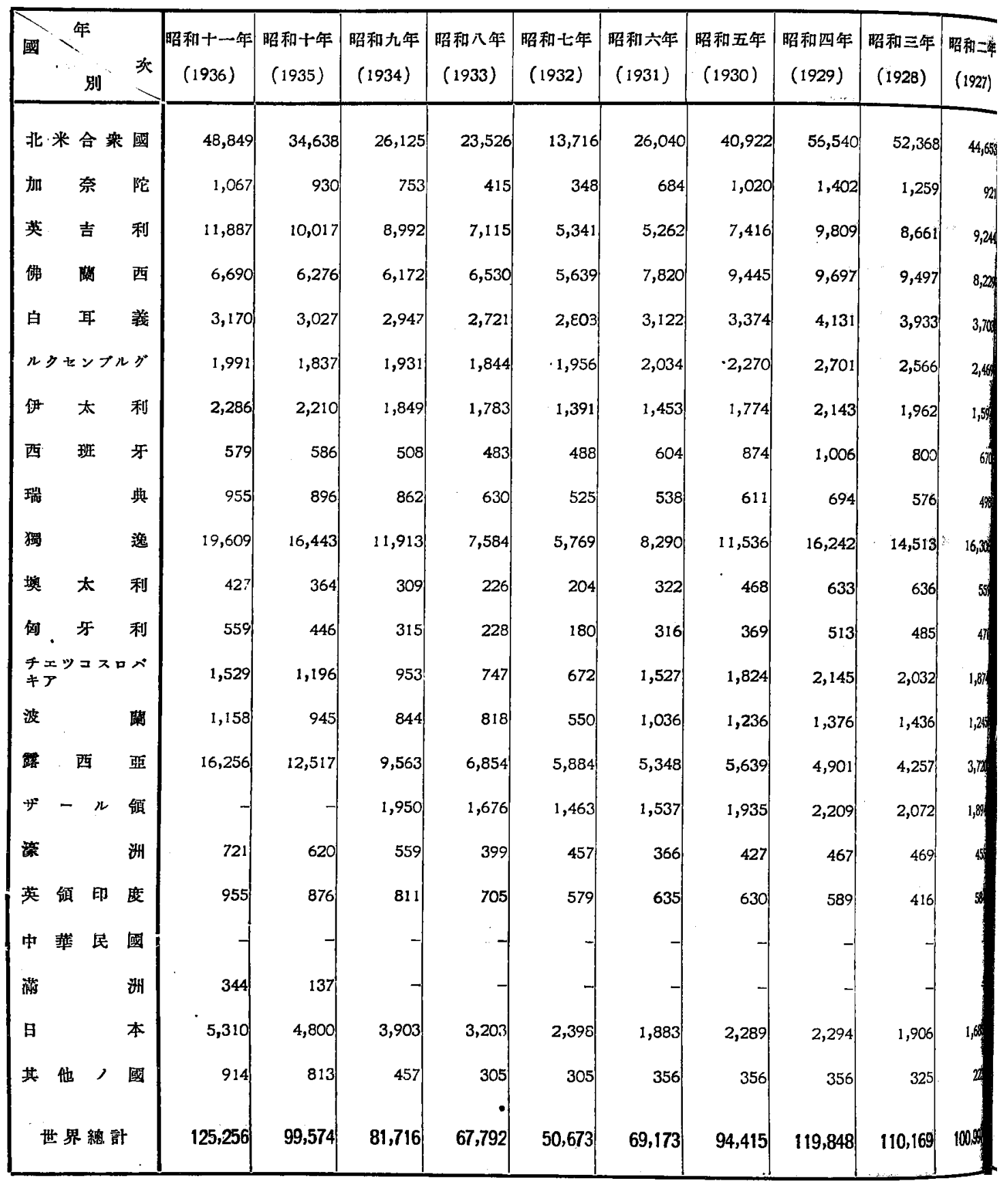

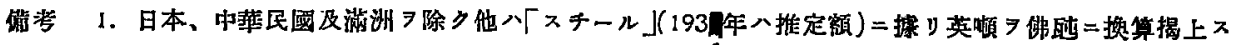

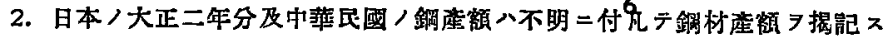

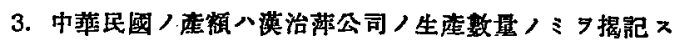

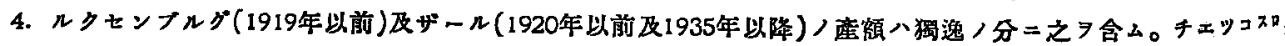




\section{$ル$ 銅 產 額 調}

(單 位 千 酶)

\begin{tabular}{|c|c|c|c|c|c|c|c|c|c|c|}
\hline $\begin{array}{c}\text { 玿和元年 } \\
(1926)\end{array}$ & $\begin{array}{c}\text { 大正十四年 } \\
(1925)\end{array}$ & $\begin{array}{c}\text { 犬正十三年 } \\
(1924)\end{array}$ & $\begin{array}{c}\text { 大正十二年 } \\
(1923)\end{array}$ & $\begin{array}{c}\text { 大正十一年 } \\
(1922)\end{array}$ & $\begin{array}{c}\text { 大正十年 } \\
\text { (1921) }\end{array}$ & $\begin{array}{c}\text { 大正九年 } \\
(1920)\end{array}$ & $\begin{array}{c}\text { 大正八年 } \\
\text { (1919) }\end{array}$ & $\begin{array}{c}\text { 大正七年 } \\
\text { (i918) }\end{array}$ & $\begin{array}{c}\text { 大正六年 } \\
\text { (1917) }\end{array}$ & $\begin{array}{c}\text { 大正二年 } \\
\text { (1913) }\end{array}$ \\
\hline 49,067 & 46,126 & 38,539 & 45,663 & 34,141 & 20,060 & 42,807 & 35,226 & 45,173 & 45,782 & 31,802 \\
\hline 789 & 765 & 660 & 899 & 493 & 680 & 1,127 & 943 & 1,722 & 1,587 & 1,060 \\
\hline 3,617 & 7,515 & 8,353 & 8,618 & 5,975 & 3,762 & 9,212 & 8,020 & 9,692 & 9,872 & 7,787 \\
\hline 8,428 & 7,442 & 6,900 & 5,109 & 4,535 & 3,058 & 3,050 & 2,185 & 1,808 & 2,231 & 4,688 \\
\hline 3,373 & 2,410 & 2,860 & 2,286 & 1,564 & 792 & 1,253 & 334 & 10 & 10 & 2,467 \\
\hline 2,243 & 2,086 & 1,887 & 1,200 & 1,390 & 759 & 570 & 366 & - & - & - \\
\hline 1,780 & 1,785 & 1,358 & 1,118 & 610 & 682 & 774 & 775 & 992 & 1,332 & 933 \\
\hline 578 & 580 & 483 & 460 & 254 & 102 & 152 & 254 & 325 & 488 & 387 \\
\hline 489 & 474 & 496 & 299 & 348 & 206 & 437 & 491 & 545 & 581 & 591 \\
\hline 12,340 & 12,190 & 9,835 & 6,303 & 11,711 & 9,994 & 9,276 & 7,872 & 11,827 & 14,318 & 18,929 \\
\hline 481 & 469 & 370 & 499 & 481 & 334 & 199 & - & - & 2,918 & 2,625 \\
\hline 325 & 238 & 239 & 350 & 300 & 91 & 41 & - & - & - & $\rightarrow$ \\
\hline 1,340 & 1,500 & 1,349 & 1,016 & 640 & 918 & 973 & 786 & 1,019 & - & - \\
\hline 789 & 783 & 682 & 1,295 & 945 & 1,500 & 61 & - & - & - & - \\
\hline 3,101 & 2,120 & 1,143 & 732 & 215 & 164 & 46 & - & - & 2,032 & 4,836 \\
\hline 1,736 & 1,575 & 1,475 & 997 & 1,265 & 1,016 & 1,006 & - & - & - & - \\
\hline 343 & 357 & 311 & 203 & 102 & 212 & 170 & 181 & 144 & 152 & - \\
\hline 528 & 456 & 341 & 218 & 178 & 185 & 158 & 190 & 187 & 166 & - \\
\hline & - & & & - & 46 & 39 & 5 & 27 & 192 & 140 \\
\hline 1,506 & 1,300 & 1,100 & 959 & 918 & 884 & 845 & 830 & 813 & 773 & 255 \\
\hline 127 & 203 & 203 & 203 & 102 & 102 & 153 & 203 & 305 & 417 & 102 \\
\hline 92,980 & 90,374 & 78,584 & 78,427 & 66,167 & 45,547 & 72,349 & 58,661 & 74,589 & 82,851 & 76,602 \\
\hline
\end{tabular}



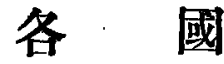

鉄

鐵

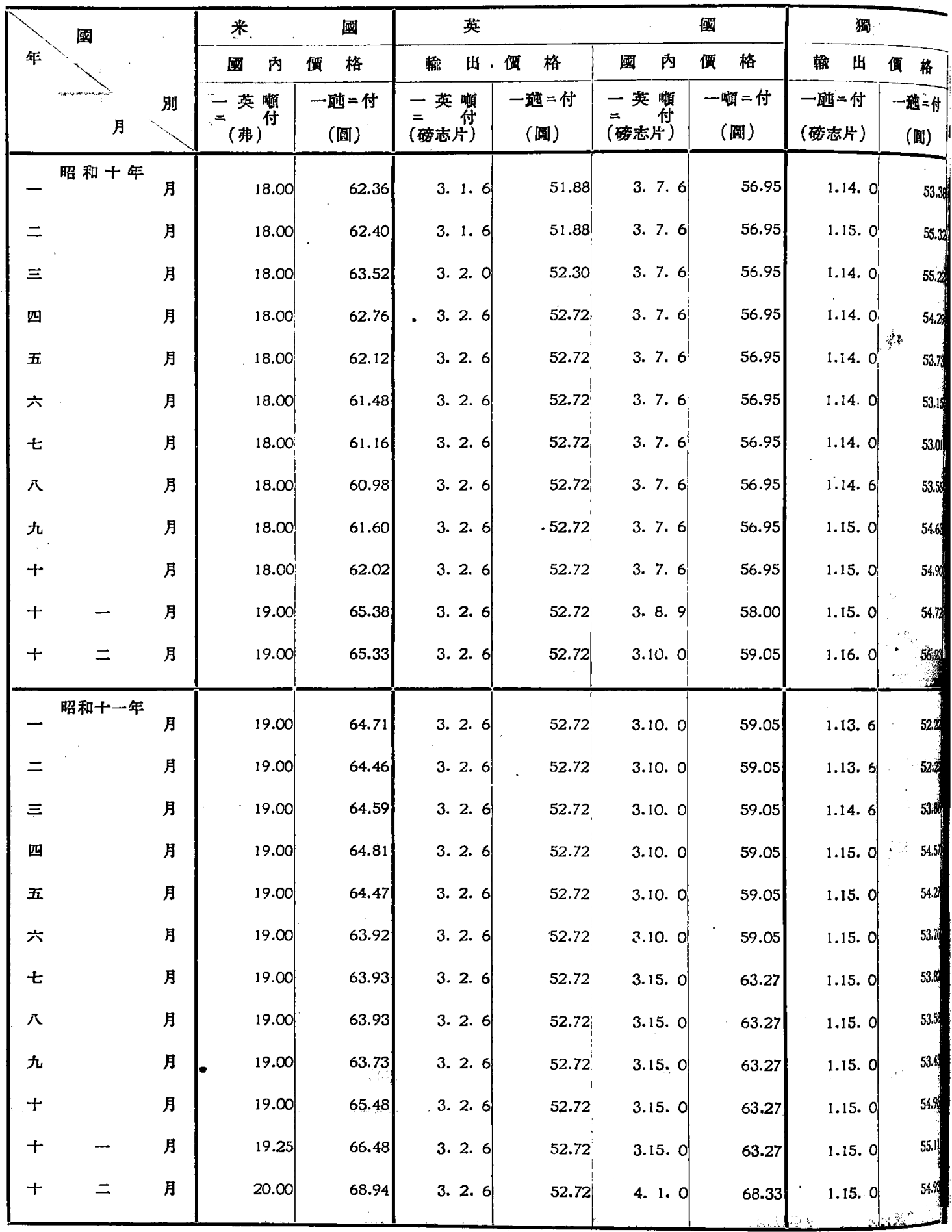

備考 本㯰格ハスチール誌二依り獨、佛、白ノ輸出偠格ハ金ボンドトス 


\begin{tabular}{|c|c|c|c|c|c|c|c|c|c|}
\hline \multicolumn{2}{|r|}{ 魀 } & \multicolumn{2}{|l|}{ 俳 } & \multicolumn{2}{|r|}{ 國 } & \multicolumn{2}{|l|}{ 白 } & 耳. & 議 \\
\hline 国 & 格 & 出 & 俓 格 & 國丙 & 颉 & 乹出 & 城 格 & 圆 & 㵋 \\
\hline $\begin{array}{l}\text { 一酎=付 } \\
(\nabla-ク)\end{array}$ & $\begin{array}{c}\text { 一趣=付 } \\
\text { （国） }\end{array}$ & $\begin{array}{l}\text { 一艅=付 } \\
\text { (研志片) }\end{array}$ & $\begin{array}{c}\text { 一㚜=仿 } \\
\text { (回) }\end{array}$ & $\begin{array}{l}\text { 一酗=付 } \\
(フ ラ ン)\end{array}$ & $\begin{array}{c}\text { 一敷=付 } \\
\text { (阅) }\end{array}$ & $\begin{array}{l}\text { 一蠤=付 } \\
\text { (碳志片) }\end{array}$ & $\begin{array}{c}\text { 一醋二付 } \\
\text { (圆) }\end{array}$ & $\begin{array}{l}\text { 一酗二付 } \\
\text { (フラン) }\end{array}$ & $\begin{array}{c}\text { 一䣩=付 } \\
\text { (脜) }\end{array}$ \\
\hline 63 & 87.15 & 1.14 .0 & 53.38 & 210 & 48.71 & 1.14. & 53.38 & 310 & 50.89 \\
\hline 63 & 89.32 & 1.15. 0 & 55.32 & 260 & 60.55 & 1.15 .0 & 55.32 & 310 & 50.95 \\
\hline 63 & 91.41 & 1.14. 0 & 55.22 & 260 & 61.88 & 1.14. 0 & 55.22 & 310 & 50.59 \\
\hline 63 & 90.01 & 1.14. 0 & 54.29 & 260 & 60.83 & 1.14 .0 & 54.29 & 340 & 40.78 \\
\hline 63 & 88.78 & 1.14. 0 & 53.73 & 260 & 59.95 & 1.14. $\mathrm{O}_{3}$ & 53.73 & 370 & 43.97 \\
\hline 63 & 88.20 & 1.14. 0 & 53.15 & 260 & 59.65 & 1.14. 0 & 53.15 & 370 & 43.50 \\
\hline 63 & 87.77 & 1.14. & 53.01 & 260 & 59.56 & 1.14. 0 & 53.01 & 370 & 43.20 \\
\hline 63 & 87.33 & 1.14 .6 & 53.55 & 260 & 59.12 & 1.14. 6 & 53.55 & 370 & 43.02 \\
\hline 63 & 87.94 & 1.15 .0 & 54.63 & 260 & 59.39 & 1.15. $\mathrm{O}^{\prime}$ & 54.63 & 370 & 43.39 \\
\hline 63 & 88.73 & 1.15. 0 & 54.90 & 260 & 59.95 & 1.15 .0 & 54.90 & 370 & 43.65 \\
\hline 63 & 88.62 & 1.15. o & 54.72 & 260 & 59.78 & 1.15. 0 & 54.72 & 375 & 44.30 \\
\hline 63 & 88.63 & 1.16 .0 & 56.23 & 260 & 59.91 & 1.16 .0 & 56.23 & 385 & 45.34 \\
\hline 63 & 88.18 & 1.13 .6 & 52.22 & 260 & 59.59 & 1.13 .6 & 52.22 & 385 & 45.12 \\
\hline 63 & 88.18 & 1.13. 6 & 52.22 & 260 & .59 .69 & 1.13 .6 & 52.22 & 385 & 45.20 \\
\hline 63 & 88.34 & 1.14. 6 & 53.86 & 260 & 59.69 & 1.14 .6 & 53.86 & 395 & 46.29 \\
\hline 63 & 88.38 & 1.15. 0 & 54.57 & 260 & 59.57 & 1.15 .1 & 54.57 & 405 & 47.47 \\
\hline 63 & 87.85 & 1.15 .0 & 54.27 & 260 & 59.15 & 1.15. 1 & 54.27 & 410 & 47.89 \\
\hline 63 & 86.95 & 1.15 .0 & 53.70 & 260 & 58.57 & 1.15. 1 & 53.70 & 410 & 47.36 \\
\hline 63 & 87.02 & 1.15. 0 & 53.82 & 282 & 63.83 & 1.15. I & 53.82 & 440 & 50.82 \\
\hline 63 & 86.73 & 1.15. 0 & 53.58 & 290 & 65.27 & 1.15. I & 53.58 & 450 & 51.89 \\
\hline 63 & 86.30 & 1.15. 0 & 53.43 & 290 & 64.40 & 1.15 .1 & 53.43 & 450 & 51.84 \\
\hline 63 & 88.85 & 1.15. 0 & 54.96 & 290 & 47.62 & 1.15 .1 & 54.96 & 460 & 54.23 \\
\hline 63 & 89.18 & 1.15. 0 & 55.11 & 315 & 51.39 & 1.15. 1 & 55.11 & 460 & 54.56 \\
\hline 63 & 89.00 & 1.15 .0 & 54.93 & 350 & 57.18 & 1.15. 1 & 54.93 & 490 & 58.02 \\
\hline
\end{tabular}




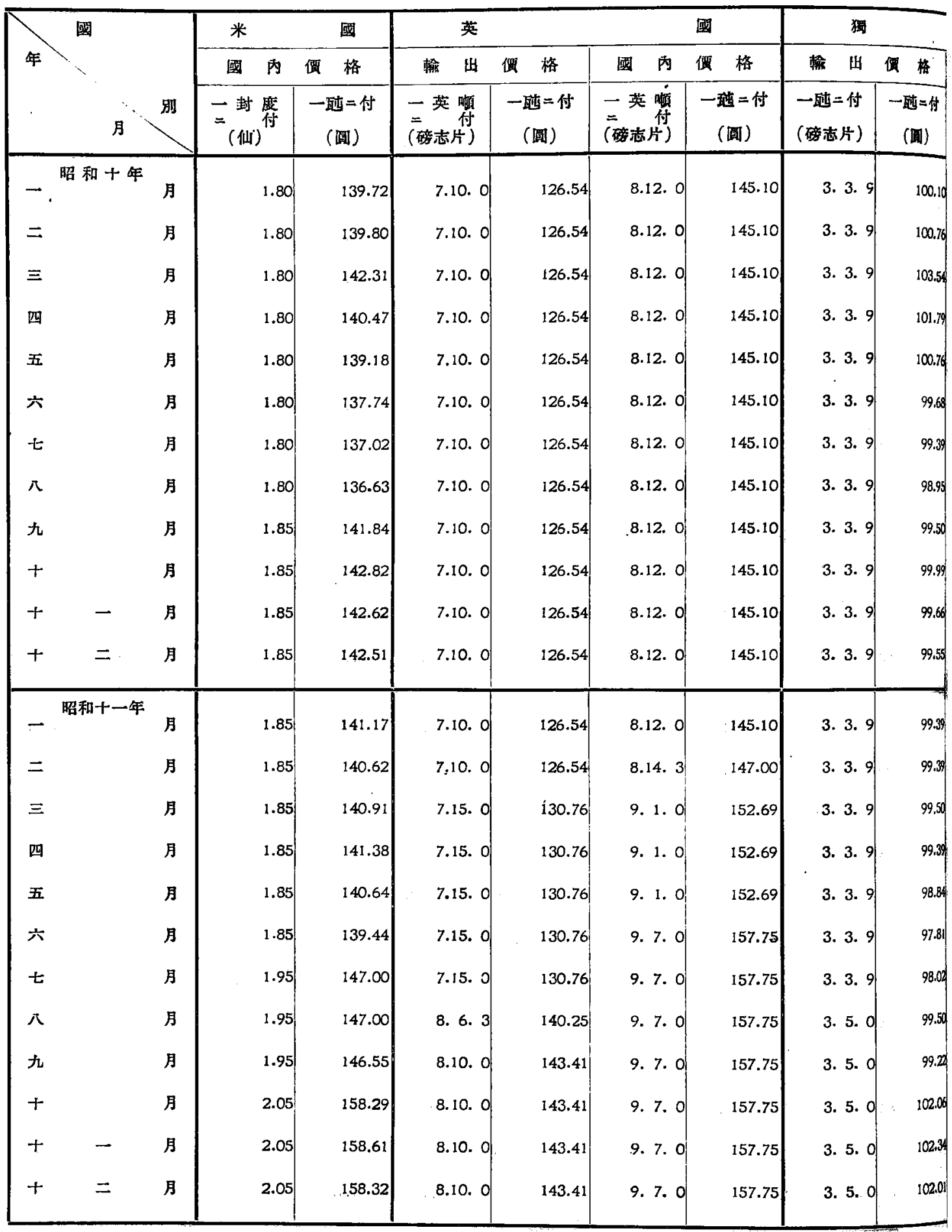




\section{市價}

\section{調}

\begin{tabular}{|c|c|c|c|c|c|c|c|c|c|}
\hline \multicolumn{2}{|r|}{ 逸 } & \multicolumn{2}{|l|}{ 佛 } & \multicolumn{2}{|r|}{ 國 } & 白 & \multicolumn{2}{|c|}{ 耳 } & 莪 \\
\hline 四 & 格 & 糯 出 & 便 格 & 國 & 㵋 & 摤 & 価 & 國 & 羁 \\
\hline $\begin{array}{l}\text { 一舴二付 } \\
(\nabla-n)\end{array}$ & $\begin{array}{c}\text { 一酎=付 } \\
\text { （國） }\end{array}$ & $\begin{array}{l}\text { 一醚=付 } \\
\text { (磁志片) }\end{array}$ & $\begin{array}{c}\text { 一配=付. } \\
\text { (周) }\end{array}$ & $\begin{array}{l}\text { 一舴=付 } \\
(フ ラ ン)\end{array}$ & $\begin{array}{c}\text { 一䣲 }=\text { 付 } \\
\text { (圆) }\end{array}$ & $\begin{array}{l}\text { 一能=付 } \\
\text { (磁志片) }\end{array}$ & 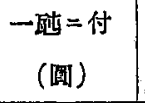 & $\begin{array}{l}\text { 一䣩=付 } \\
(\text { フラン) }\end{array}$ & $\begin{array}{c}\text { 一酎 }=\text { 付 } \\
\text { （啹） }\end{array}$ \\
\hline 110 & 155.65 & 3. 3. 9 & 100.10 & 560 & 129.90 & 3. 3. 9 & 100.10 & 550 & 90.28 \\
\hline 110 & 155.96 & 3. 3. 9 & 100.76 & 560 & 130.41 & 3. 3. 9 & 100.76 & 550 & 90.39 \\
\hline $110^{\circ}$ & 159.61 & 3. 3. 9 & 103.54 & 560 & 133.27 & 3. 3. 9 & 103.54 & 550 & 89.75 \\
\hline$\cdot 110^{\prime}$ & 157.17 & 3. 3. 9 & 101.79 & 560 & 131.02 & 3. 3. 9 & 101.79 & 560 & 67.16 \\
\hline 110 & .155 .02 & 3. 3. 9 & 100.76 & 560 & 129.12 & 3. 3.9 & 100.76 & 600 & 71.31 \\
\hline 110 & 154.00 & 3. 3. 9 & 99.68 & 560 & 128.47 & 3. 3. 9 & 99.68 & 600 & 70.54 \\
\hline 110 & 153.25 & 3. 3. 9 & 99.39 & 560 & 128.29 & 3. 3. 9 & 99.39 & 600 & 70.06 \\
\hline 110 & 152.48 & 3. 3. 9 & \8.95 & 560 & 127.33 & 3. 3. 9 & 98.95 & 600 & 69.76 \\
\hline $110^{\circ}$ & 153.55 & 3. 3. 9 & 99.50 & 560 & 127.91 & 3. 3. 9 & 99.50 & 600 & 70.36 \\
\hline 110 & 154.93 & 3. 3. 9 & 99.99 & 560 & 129.12 & 3. 3. 9 & 99.99 & 600 & 70.78 \\
\hline 110 & 154.73 & 3. 3. 9 & 99.66 & 560 & 128.77 & 3. 3. 9 & 99.66 & 600 & 70.88 \\
\hline 110 & 154.76 & 3. 3. 9 & 99.55 & 560 & 129.03 & 3. 3.9 & 99.55 & 600 & 70.66 \\
\hline 110 & 153.96 & 3. 3. 9 & 99.39 & 560 & 128.35 & 3. 3. 9 & 99.39 & 600 & 70.32 \\
\hline 110 & 153.97 & 3. 3. 9 & 99.39 & 560 & 128.58 & 3. 3. 9 & 99.39 & 625 & 73.44 \\
\hline 110 & 154.23 & 3. 3. 9 & 99.50 & 560 & 128.58 & 3. 3. 9 & 99.50 & 650 & 76.25 \\
\hline 110 & 154.32 & 3. 3.9 & 99.39 & 560 & 128.30 & 3. 3. 9 & 99.39 & 650 & 76.18 \\
\hline 110 & 153.38 & 3. 3. 9 & 98.84 & 560 & 127.40 & 3. 3.9 & 98.84 & 650 & 75.92 \\
\hline 110 & 151.82 & 3. 3. 9 & 97.81 & 560 & 126.17 & 3. 3. 9 & 97.81 & 650 & 75.14 \\
\hline 110 & 151.94 & 3. 3. 9 & 98.02 & 612 & 138.52 & 3. 3. 9 & 98.02 & 650 & 75.08 \\
\hline 110 & 151.43 & 3. 5. 0 & 99.50 & 630 & 141.81 & 3. 5.0 & 99.50 & 700 & 80.71 \\
\hline 110 & 150.69 & 3. 5.0 & 99.22 & 630 & 139.92 & 3. 5.0 & 99.22 & 700 & 80.64 \\
\hline 110 & 155.14 & 3.5 .0 & 102.06 & 655 & 107.55 & 3. 5.0 & 102.06 & 700 & 82.53 \\
\hline 110 & $\therefore 155.70$ & 3.5 .0 & 102.34 & 665 & 108.07 & 3. 5.0 & 102.34 & 700 & 83.02 \\
\hline 110 & 155.40 & 3. 5.0 & 102.01 & 695 & 113.56 & 3. 5.0 & 102.01 & 700 & 82.88 \\
\hline
\end{tabular}




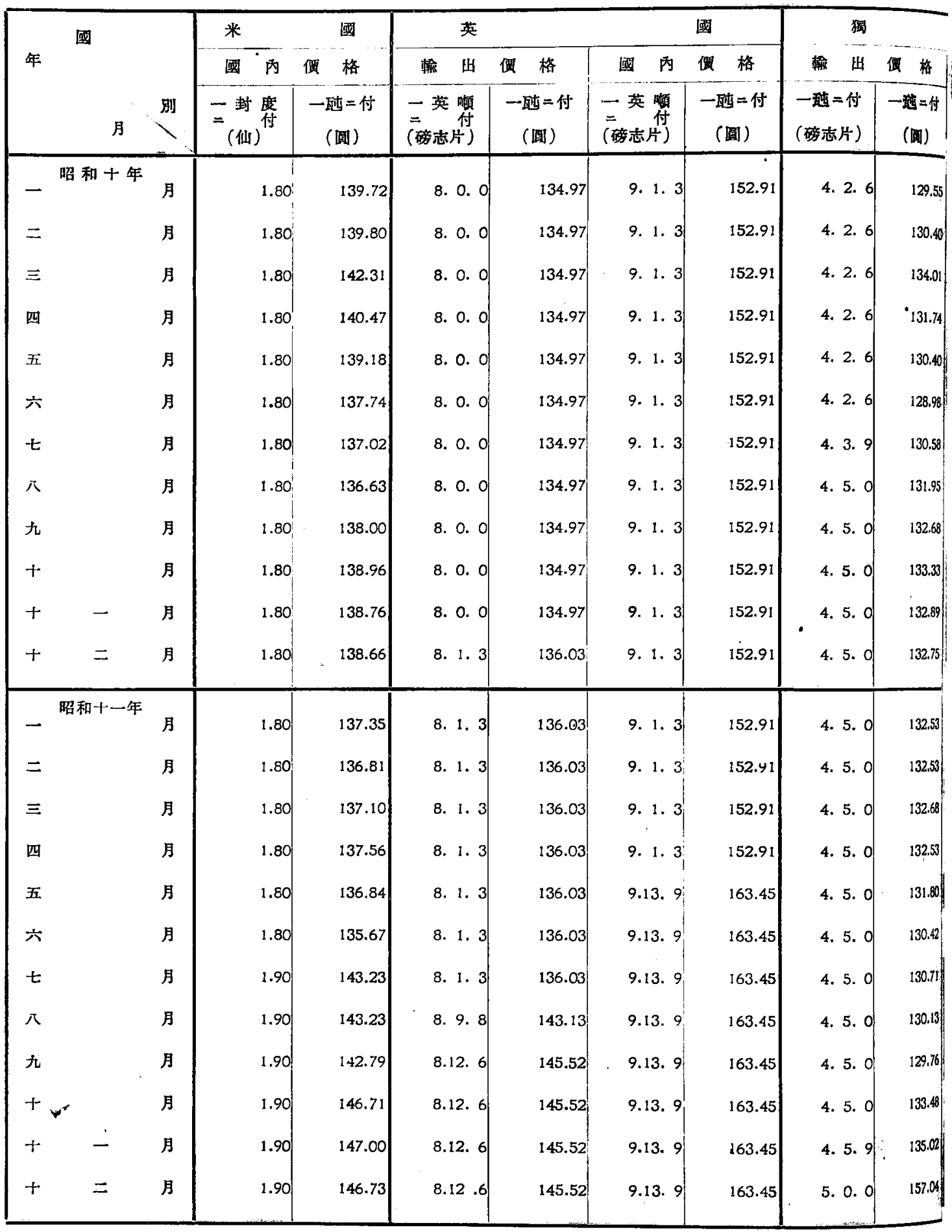




\begin{tabular}{|c|c|c|c|c|c|c|c|c|c|}
\hline \multicolumn{2}{|r|}{ 逸 } & \multicolumn{2}{|l|}{ 俳 } & \multicolumn{2}{|r|}{ 國 } & \multicolumn{3}{|c|}{ 耳 } & 義 \\
\hline 国内 & 格 & 輸 出 & 格 & 國 & 㵋 & 輸出 & 硔 & 國 & 蚠 \\
\hline $\begin{array}{l}\text { 一鸽=付 } \\
(\nabla-y)\end{array}$ & $\begin{array}{l}\text { 一蒴=付 } \\
\text { （国） }\end{array}$ & $\begin{array}{l}\text { 一酗=付 } \\
(\text { 磅志片) }\end{array}$ & $\begin{array}{c}\text { 一酎二付 } \\
\text { (国) }\end{array}$ & $\begin{array}{l}\text { 一䣩=付 } \\
(フ ラ ン)\end{array}$ & $\begin{array}{c}\text { 一䣩 }=\text { 付 } \\
\text { (圆) }\end{array}$ & $\begin{array}{l}\text { 一虫二付 } \\
\text { (磅志片) }\end{array}$ & $\begin{array}{c}\text { 一通 }=\text { 付 } \\
\text { (國) }\end{array}$ & $\begin{array}{l}\text { 一酺=付 } \\
(\text { フラン) }\end{array}$ & $\begin{array}{c}\text { 一醚=付 } \\
\text { （國） }\end{array}$ \\
\hline 127 & 179.71 & 4. 2. 6 & 129.55 & 700 & 162.38 & 4. 2. 6 & 129.55 & 700 & 114.90 \\
\hline 127 & 180.07 & 4. 2. 6 & 130.40 & 700 & 163.02 & 4. 2.6 & 130.40 & 700 & 115.04 \\
\hline 127 & 184.27 & 4. 2. 6 & 134.01 & 700 & 166.59 & 4. 2.6 & 134.01 & 700 & 114.23 \\
\hline 127 & 181.46 & 4. 2.6 & 131.74 & 700 & 163.78 & 4. 2.6 & 131.74 & 710 & 85.15 \\
\hline 127 & 178.97 & 4. 2.6 & 130.40 & 700 & 161.40 & 4. 2. 6 & 130.40 & 750 & 89.13 \\
\hline 127 & 177.80 & 4. 2.6 & 128.98 & 700 & 160.59 & 4. 2.6 & 128.98 & 700 & 82.30 \\
\hline 127 & 176.93 & 4. 3.9 & 130.58 & 700 & 160.37 & 4. 3. 9 & 130.58 & 700 & 81.74 \\
\hline 127 & 176.05 & 4. 5.0 & 131.95 & 700 & 159.16 & 4. 5.0 & 131.95 & 700 & 81.39 \\
\hline 127 & 177.28 & 4. 5.0 & 132.68 & 700 & I59.89 & 4. 5.0 & 132.68 & 700 & 82.08 \\
\hline 127 & 178.87 & 4. 5.0 & 133.33 & 700 & 161.40 & 4. 5.0 & 133.33 & 700 & 82.58 \\
\hline 127 & 178.65 & 4. 5.0 & 132.89 & 700 & 160.96 & 4. 5.0 & I 32.89 & 700 & 82.69 \\
\hline 127 & 178.67 & 4. 5.0 & 132.75 & 700 & 161.29 & 4. 5. 0 & 132.75 & 700 & 82.44 \\
\hline 127 & 177.76 & 4. 5.0 & 132.53 & 700 & 160.44 & 4. 5.0 & I32.53 & 700 & 82.04 \\
\hline 127 & 177.76 & 4. 5. 0 & 132.53 & 700 & 160.72 & 4. 5.0 & 132.53 & 750 & 88.13 \\
\hline 127 & 178.07 & 4. 5.0 & 132.68 & 700 & 160.72 & 4. 5.0 & 132.68 & 800 & 93.84 \\
\hline 127 & 178.17 & 4. 5.0 & 132.53 & 700 & 160.37 & 4. 5.0 & 132.53 & 800 & 93.76 \\
\hline 127 & 177.09 & 4. 5.0 & 131.80 & 700 & 159.25 & 4.5. 0 & 131.80 & 800 & 93.44 \\
\hline 127 & 175.29 & 4. 5.0 & 130.42 & 700 & 157.71 & 4. 5.0 & 130.42 & 800 & 92.48 \\
\hline 127 & 175.42 & 4. 5. 0 & 130.71 & 765 & 173.15 & 4. 5. 0 & 130.71 & 800 & 92.40 \\
\hline 127 & 174.84 & 4. 5.0 & 130.13 & 790 & 177.83 & 4. 5.0 & 130.13 & 850 & 98.01 \\
\hline 127 & 173.97 & 4. 5. 0 & 129.76 & 790 & 175.46 & 4. 5.0 & 129.76 & 850 & 97.92 \\
\hline 127 & 179.12 & 4. 5. & 133.48 & 820 & 134.65 & 4. 5.0 & 133.48 & 850 & 100.22 \\
\hline 127 & 179.77 & 4. 5.9 & 135.02 & 830 & 135.37 & 4. 5.9 & 135.02 & 850 & 100.81 \\
\hline 127 & 179.41 & 5.0 .0 & 157.04 & 875 & 142.98 & 5.0 .0 & 157.04 & 850 & 100.64 \\
\hline
\end{tabular}


英米二於ヶル銑鐵及鋼材價格

\begin{tabular}{|c|c|c|c|c|c|c|c|c|c|c|c|c|c|c|}
\hline & & 别 & * & & 國 & & 英 & & & & & 國 & & \\
\hline 年 & $>$ & & 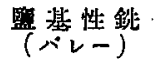 & 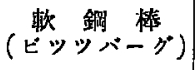 & $\begin{array}{l}\text { タンシクプレート } \\
(\text { ビッッバーグ) }\end{array}$ & $\begin{array}{l}n y-7 \\
\equiv\end{array}$ & $\overrightarrow{7} \bar{\imath}$ & & 棒 & & 銅 & 錭 & & \\
\hline & & & 一卖顿 =付 & 一封度 $=$ 付 & 一封庪 = 付 & 一英濑 & 頙 $=$ 付 & & 一英吪 & 顿 $=\uparrow$ & & 一䒨叫 & 佂 & \\
\hline 明治 & 三十三年 & $(1900)$ & 無 & 1.59 & 1.54 & 3 & 密 & & 醇 & 殸 & & D & 売 & \\
\hline 同 & 三十四年 & (1901) & - & 1.43 & 1.55 & 2 & 7 & & & - & & & - & \\
\hline 同 & 三十五年 & $(1902)$ & - & 1.45 & 1.70 & 2 & 6 & 10 & & - & & & - & \\
\hline 同 & 三十六年 & $(1903)$ & - & 1.56 & 1.61 & 2 & 6 & & & - & & & - & \\
\hline 同 & 三十七年 & (1904) & 12.59 & 1.33 & 1.54 & 2 & 2 & & & - & & & - & \\
\hline 同 & 三十八年 & $(1905)$ & 15.25 & 1.48 & 1.58 & 2 & 6 & 6 & 5 & 8 & 8 & 5 & 16 & \\
\hline 同 & 三十九年 & (1906) & 18.10 & 1.51 & 1.61 & 2 & 11 & 4 & 6 & 10 & $1 \mathrm{I}$ & 6 & 4 & \\
\hline 同 & 四 十 年 & (1907) & 20.87 & 1.60 & 1.70 & 2 & 15 & 10 & 7 & 0 & 11 & 6 & 13 & \\
\hline 京 & 四十一年 & (1908) & 15.16 & 1.49 & 1.64 & 2 & 10 & 1 & 9 & 16 & 6 & 5 & 19 & \\
\hline 同 & 四十二年 & (1909) & 15.48 & 1.33 & 1.42 & 2 & 8 & 6 & 6 & 9 & 10 & 5 & 19 & \\
\hline 间 & 四十三年 & $(1910)$ & 14.76 & 1.44 & 1.47 & 2 & 10 & 6 & 6 & 8 & 6 & 5 & 17 & \\
\hline & 四十四年 & (1911) & 13.07 & 1.26 & 1.31 & 2 & 8 & 4 & 6 & 6 & 1 & 6 & 2 & \\
\hline 大 正 & 正 元 年 & $(1912)$ & 13.92 & 1.29 & 1.33 & 2 & 10 & 3 & 6 & 15 & 7 & 6 & 5 & \\
\hline & 二 年 & (1913) & 14.71 & 1.55 & 1.50 & 4 & 4 & 0 & 7 & 10 & 11 & 6 & 11 & 2. \\
\hline & 三 年 & (1914) & 12.87 & 1.15 & 1.14 & 2 & 13 & 2 & 6 & 16 & 11 & 6 & 15 & \\
\hline & 四 年 & (1915) & 13.74 & 1.31 & 1.31 & 3 & 0 & 8 & 8 & 8 & 1 & 7 & 18 & \\
\hline 同 & 五 年 & (1916) & 19.76 & 2.67 & 1.53 & 4 & 21 & 10 & 12 & 4 & 6 & 11 & 15 & 6 \\
\hline 同 & 六 年 & (1917) & 38.90 & 2.63 & 5.88 & 4 & 14 & 5 & 13. & 11 & 9 & 13 & 11 & 1 \\
\hline 同 & 七 年 & $(1918)$ & 32.50 & 2.89 & 3.24 & 5 & 13 & 5 & 14 & 10 & 8 & 15 & 7 & \\
\hline 同 & 八 年 & (1919) & 27.65 & 2.50 & 2.72 & 7 & 5 & 0 & 20 & 9 & 1 & & - & \\
\hline 同 & 九 年 & $(1920)$ & 42.21 & 3.22 & 3.28 & 10 & 6 & 0 & 27 & 17 & 1 & & - & \\
\hline 同 & 十 年 & (1921) & 21.74 & 1.87 & 1.98 & 7 & 1 & 7 & 21 & 3 & o. & & - & \\
\hline 间] & 十一年 & $(1922)$ & 24.20 & 1.72 & 1.72 & 4 & 10 & 8 & 9 & 12 & 6 & 9 & 16 & \\
\hline 闰 & 十二年 & (1923) & 25.81 & 2.36 & 2.43 & 5 & 8 & 6 & 9 & 10 & 0 & 10 & 1 & \\
\hline 同 & 十三年 & (1924) & 20.23 & 2.20 & 2.11 & 4 & 8 & 8 & 10 & 6 & 2 & 10 & 3 & \\
\hline 䣓 & 十四年 & (1925) & 19.59 & 2.02 & 1.91 & 3 & 12 & 8. & 7 & 19 & 9 & 8 & 5 & \\
\hline 昭 和 & 和 元 年 & (1926) & 19.29 & 1.99 & 1.89 & 4 & 7 & 9 & 7 & 6 & 2 & 7 & 4 & 3 \\
\hline 京 & 二 年 & (1927) & 17.75 & 1.84 & 1.82 & 3 & 12 & 10 & 7 & 10 & 11 & 8 & 18 & 8 \\
\hline 同 & 三 年 & $(1928)$ & 16.65 & 1.88 & 1.83 & 3 & 51 & 10 & 7 & 5 & 8 & 8 & 1 & 10 \\
\hline 同 & 四＼cjkstart年 & (1929) & 18.20 & 1.93 & 1.93 & 3 & 10 & 2 & 8 & 1 & 11 & 8 & 2 & \\
\hline 同 & 五：年 & (1930) & 18.00 & 1.72. & 1.70 & 3 & 7 & 1 & 7 & 18 & 4 & 8 & 5 & a \\
\hline 同 & 六 年 & (1931) & 16.59 & 1.63 & 1.62 & 2 & 18 & 6 & 7 & 6 & 9 & 8 & 5 & of \\
\hline 同 & 七 年 & (1932) & 14.46 & 1.58 & 1.58 & 2 & 18 & 6 & 6 & 3 & 10 & 8 & 15 & of \\
\hline 同 & 八 年 & (1933) & 15.42 & 1.64 & 1.61 & 2 & 18 & 6 & 6 & 11 & 9 & 8 & .6 & of \\
\hline 同” & 九 年 & (1934) & 17.72 & 1.81 & 1.78 & 2 & 19 & 10 & 7 & 8 & 4 & 8 & 0 & of \\
\hline 同 & 十 年 & (1935) & 18.17 & 1.82 & 1.80 & 3 & 2 & 4 & 7 & 10 & of & 8 & 0 & \\
\hline 同 & 十一年 & (1936) & 19.10 & 1.93 & 1.85 & 3 & 2 & 6 & 8 & 0 & 1 & 8 & 5 & 8. \\
\hline
\end{tabular}

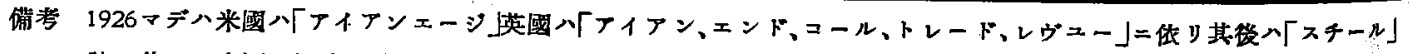
誌二传儿。米國八國內僄格英國八輸此價格ナリ 


\section{本邦鐵鋼材關稅芼表}




\section{本 邦 鐵 鋼 材}

\begin{tabular}{|c|c|c|c|c|c|}
\hline 號 & 昆 & 稆 & 率 & 每 啮 & 換算 \\
\hline 462 & 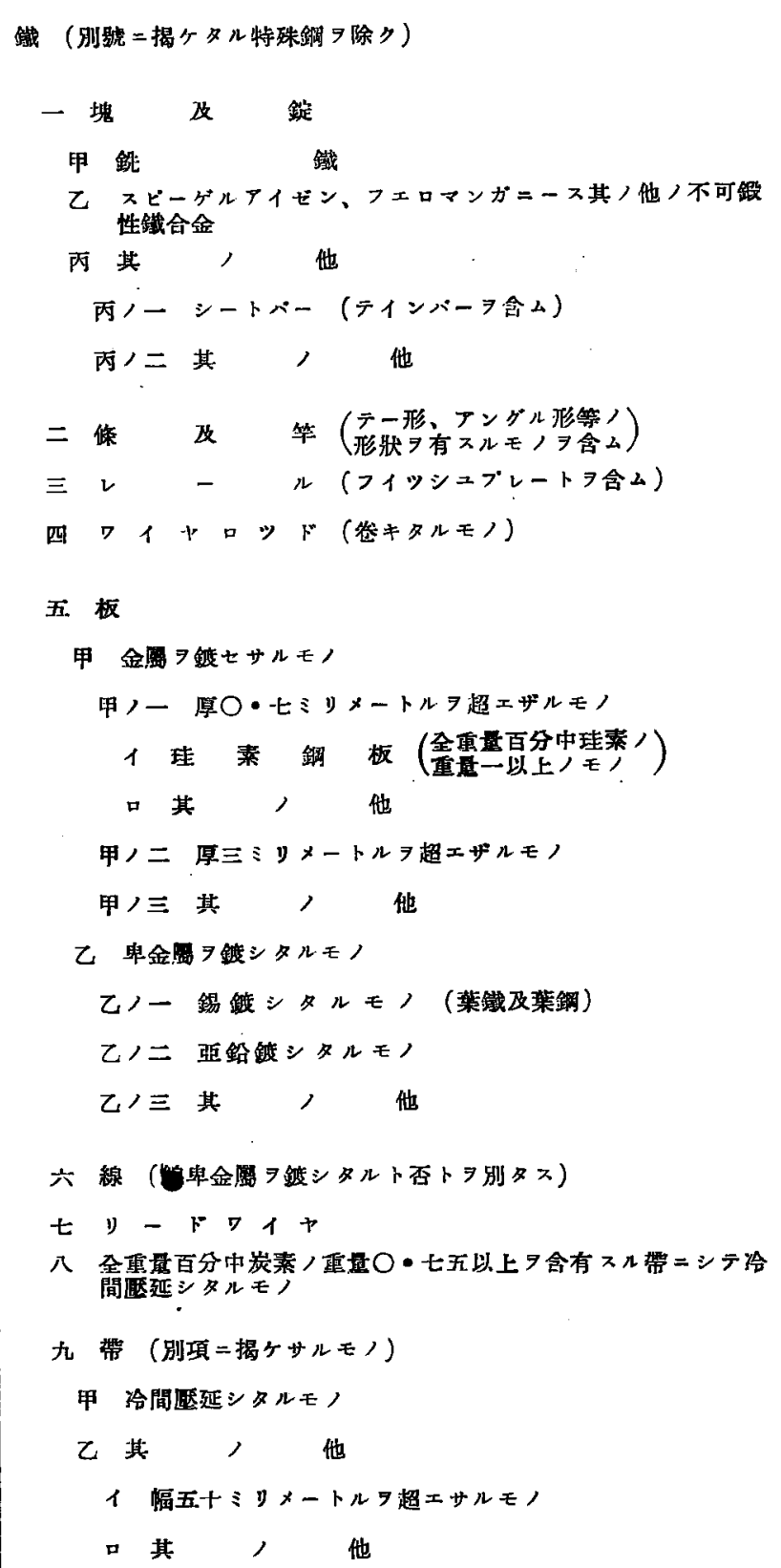 & 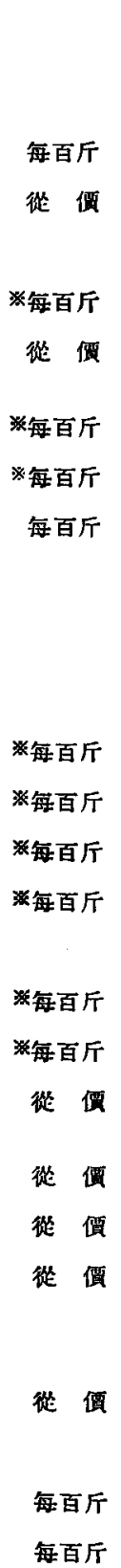 & 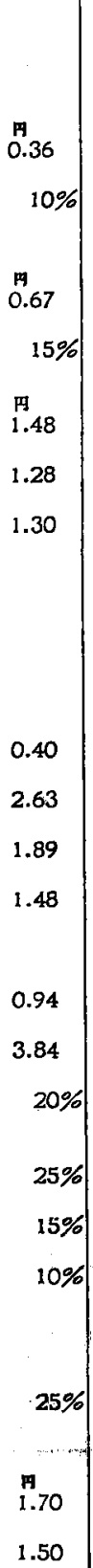 & $\begin{array}{l}* \\
※ \\
* \\
* \\
*\end{array}$ & $\begin{array}{l}6.66 \\
43.83 \\
31.50 \\
24.66\end{array}$ \\
\hline
\end{tabular}




\section{關 稅 率 表}

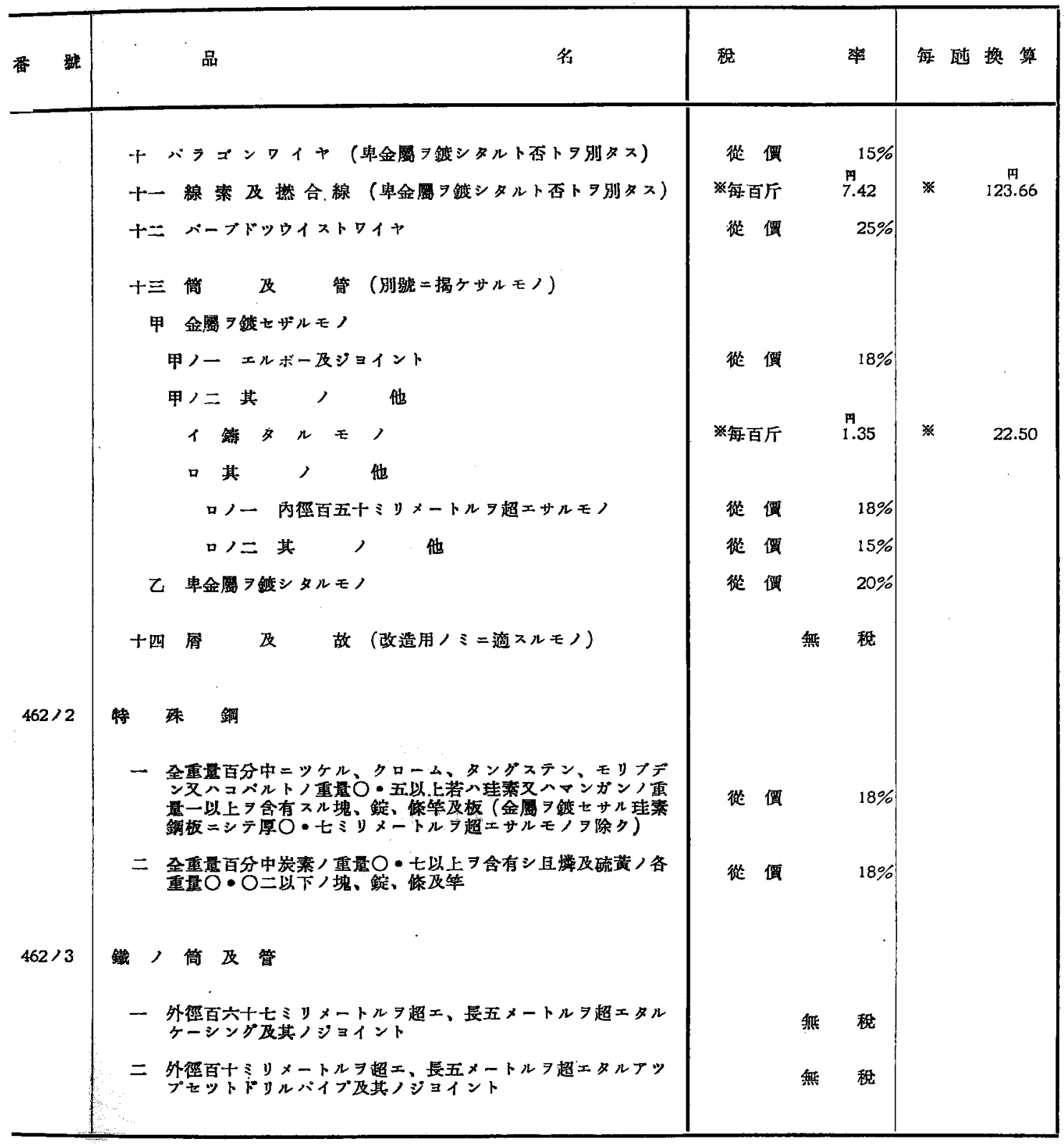

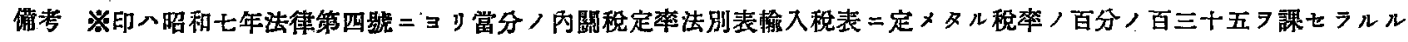
モノトス

昭和十二年栜 命第百三十㩆

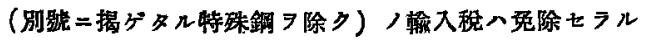

